\title{
Roditeljske odrednice učeničkih obrazovnih ishoda u matematici i tehničkoj kulturi
}

Šimunović, Mara

Doctoral thesis / Disertacija

2020

Degree Grantor / Ustanova koja je dodijelila akademski / stručni stupanj: University of Zagreb, University of Zagreb, Faculty of Humanities and Social Sciences / Sveučilište u Zagrebu, Filozofski fakultet

https://doi.org/10.17234/diss.2020.210482

Permanent link / Trajna poveznica: https://urn.nsk.hr/urn:nbn:hr:131:076747

Rights / Prava: In copyright/Zaštićeno autorskim pravom.

Download date / Datum preuzimanja: 2023-04-26

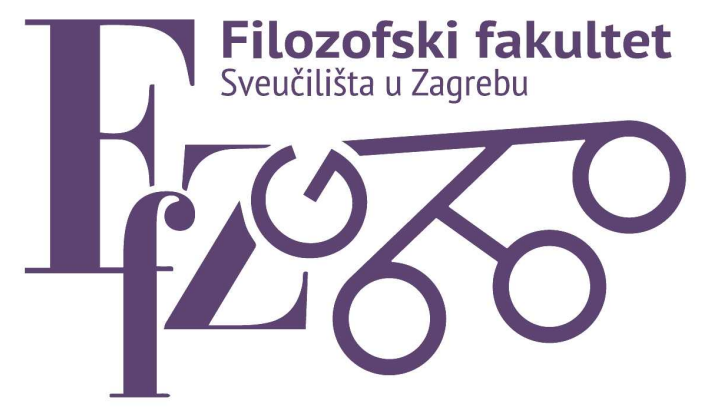

Repository / Repozitorij:

ODRAZ - open repository of the University of Zagreb

Faculty of Humanities and Social Sciences
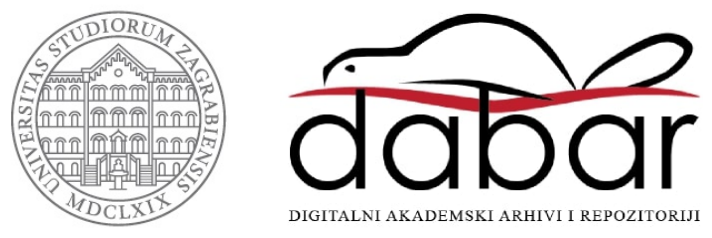


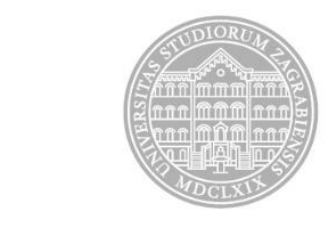

Sveučilište u Zagrebu

Filozofski fakultet

Mara Šimunović

\section{RODITELJSKE ODREDNICE UČENIČKIH OBRAZOVNIH ISHODA U MATEMATICI I TEHNIČKOJ KULTURI}

DOKTORSKI RAD

Zagreb, 2020. 


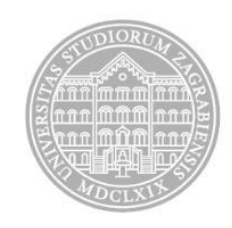

Sveučilište u Zagrebu

Filozofski fakultet

Mara Šimunović

\title{
RODITELJSKE ODREDNICE UČENIČKIH OBRAZOVNIH ISHODA U MATEMATICI I TEHNIČKOJ KULTURI
}

\author{
DOKTORSKI RAD
}

Mentorica: Dr. sc. Nina Pavlin-Bernardić, izv. prof.

Zagreb, 2020. 



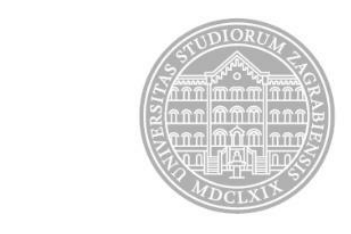

University of Zagreb

Faculty of Humanities and Social Sciences

Mara Šimunović

\title{
PARENTAL DETERMINANTS OF STUDENTS' EDUCATIONAL OUTCOMES IN MATHEMATICS AND TECHNICAL EDUCATION
}

\author{
DOCTORAL DISSERTATION
}

Supervisor: Assoc. Prof. Nina Pavlin-Bernardić, PhD

Zagreb, 2020 



\section{O MENTORICI}

Nina Pavlin-Bernardić rođena je u Beogradu 1979. godine. Osnovno školovanje započela je u Beogradu, a završila ga u Zagrebu, gdje je završila i gimnaziju općeg smjera. Studij psihologije na Odsjeku za psihologiju Filozofskog fakulteta Sveučilišta u Zagrebu završila je 2003. godine, a doktorirala je 2010. godine. Asistenticom na Odsjeku za psihologiju Filozofskog fakulteta u Zagrebu postala je 2004. godine, u zvanje više asistentice izabrana je 2010. godine, u zvanje docentice 2012. godine, a u zvanje izvanredne profesorice 2020. godine. Od 2012. do 2019. godine bila je zaposlena na Filozofskom fakultetu i Hrvatskim studijima Sveučilišta u Zagrebu u kumulativnom radnom odnosu po 50\% radnog vremena, a od 2019. godine zaposlena je na puno radno vrijeme na Filozofskom fakultetu Sveučilišta u Zagrebu. Nastavno je i znanstveno usmjerena na područje psihologije obrazovanja i školske psihologije. Vodila je više kolegija iz ovog područja na Filozofskom fakultetu i Hrvatskim studijima, kao što su Psihologija obrazovanja: motivacijsko-socijalni procesi, Psihologija odgoja $i$ obrazovanja, Metodika nastave psihologije, Metodički praktikum i Psihologija darovitih, a na Poslijediplomskom studiju psihologije kolegij Suvremeni pristupi istraživanjima motivacije za učenje. Također je vodila kolegije Teorijski sustavi u psihologiji i Psihologija učenja na Hrvatskim studijima.

Izv. prof. dr. sc. Nina Pavlin-Bernardić radila je na više znanstveno-istraživačkih projekata kao suradnica i voditeljica. Objavila je 19 znanstvenih radova, 10 stručnih radova, 12 poglavlja u knjigama i jednu uredničku knjigu. Od akademske godine 2015/2016. obnaša dužnost predstojnice Katedre za školsku psihologiju. Dobitnica je timske državne nagrade Ivan Filipović u području znanstvenog i stručnog rada za 2014. godinu. 


\section{ZAHVALE}

Zahvaljujem se svojoj mentorici, dr. sc. Nini Pavlin-Bernardić, na predanom vođenju kroz čitavi proces izrade ovog doktorskog rada. Hvala Vam na bezrezervnoj podršci, ohrabrenju $i$

optimizmu.

Hvala mojim divnim prijateljima i kolegama na zajedništvu, prihvaćanju i inspiraciji.

Najveće hvala mojoj Duci i mojoj Luciji. Hvala vam što je svako moje putovanje i vaše. 
Ovaj rad posvećujem svojoj majci.

Hvala ti što si mi svaki dan pokazivala koliko vjeruješ u mene.

"Education is a shared commitment between dedicated teachers, motivated students and enthusiastic parents with high expectations." Bob Beauprez 


\section{SAŽETAK}

Zbog nedovoljnog broja mladih koji se odlučuju za obrazovanje u STEM području (prirodoslovlje, tehnologija, inženjerstvo, matematika), važno je utvrditi čimbenike koji mogu utjecati na taj odabir. Cilj istraživanja bio je ispitati roditeljske odrednice učeničkih motivacijskih uvjerenja, slobodnih aktivnosti i postignuća u dvama STEM školskim područjima - matematici i tehničkoj kulturi. Kao teorijski okvir korišten je model očekivanja i vrijednosti i model roditeljske socijalizacije dječjih obrazovnih ishoda Eccles i suradnika. Primjenom upitnika prikupljeni su podaci od 1064 učenika šestih i sedmih razreda iz 16 osnovnih škola iz Zagreba i okolice, dok su upitnicima za roditelje prikupljeni podaci od istog broja njihovih roditelja. Analize strukturalnih modela pokazale su da ispitane roditeljske odrednice imaju različitu ulogu u objašnjavanju učeničkih obrazovnih ishoda. Obrazovanje roditelja nije bilo značajan prediktor učeničkih obrazovnih ishoda u matematici, dok je u tehničkoj kulturi negativno predviđalo sva tri motivacijska uvjerenja učenika (samoefikasnost, interes i važnost predmeta). Roditeljska uvjerenja o višoj djetetovoj sposobnosti, trudu i interesu za predmet i višoj korisnosti predmeta za dijete predviđala su viša učenička motivacijska uvjerenja i postignuće u oba predmeta. Potvrđena je hipoteza o roditeljima kao "tumačima stvarnosti" budući da su u oba predmeta roditeljska uvjerenja bila medijator između učeničkog prošlog postignuća i kasnije samoefikasnosti u predmetu. Nalazi vezani uz roditeljska ponašanja razlikovali su se s obzirom na područje. Roditeljsko modeliranje matematičkih aktivnosti nije bilo prediktor učeničkih ishoda u matematici, dok je modeliranje tehničkih aktivnosti predviđalo viši učenički interes i važnost tehničke kulture te češće bavljenje izvanškolskim tehničkim aktivnostima. Roditeljska uključenost u učeničke obaveze iz matematike je predviđala niži učenički interes za matematiku i rjeđe bavljenje matematičkim izvanškolskim aktivnostima. Roditeljsko poticanje interesa za matematičko, odnosno tehničko područje je predviđalo češće učeničko bavljenje izvanškolskim aktivnostima u oba područja te viši učenički interes za matematiku. Dio roditeljskih učinaka bio je izravan, a dio neizravan pri čemu su učenička motivacijska uvjerenja bila važni medijatori pojedinih roditeljskih učinaka. Također je ispitana moderatorska uloga roda učenika te obrazovanja roditelja. Roditeljski učinci su bili jednaki za učenike i učenice, no obrazovanje roditelja je bilo značajan moderator $u$ strukturalnim modelima iz matematike. Istraživanje doprinosi spoznajama o nedovoljno istraženim elementima modela roditeljske socijalizacije dječjih obrazovnih ishoda, ali i spoznajama o socijalizaciji u STEM obrazovnom području. 
Ključne riječi: roditeljski utjecaji; socijalizacija; matematika; tehnička kultura; STEM obrazovanje; obrazovni ishodi 


\section{EXTENDED SUMMARY}

\section{Introduction}

Ever since the Second World War, knowledge and skills in the STEM (Science, Technology, Engineering, and Mathematics) area have been the key to economic progress (Ritz \& Fan, 2015). However, many countries today are facing a shortage of workforce in STEM sectors (European Centre for the Development of Vocational Training, 2016; President's Council of Advisors on Science and Technology, 2012). This problem cannot be considered separately from the problems and specificities associated with the STEM education. Even early educational experiences in primary school can determine the later educational and professional path of an individual (Tai, Qi Liu, Maltese, \& Fan, 2006). Because of this, it is important to identify as many determinants of student educational outcomes in the STEM domain. Parents, along with teachers, have been recognized as crucial socializing factors in this area (Chouinard, Karsenti, \& Roy, 2007).

It has been shown that in empirical research STEM should be conceptualized as a heterogeneous domain. For example, prior research found that there is a differentiation in student motivational beliefs in different STEM school subjects (Simpkins, Price, \& Garcia, 2015) and that gender segregation is not equal across STEM fields (Mann \& DiPrete, 2013). The heterogeneous conceptualization of the STEM domain is even more needed in research that is embedded in the educational contexts such as Croatian, in which there is no integrated teaching of STEM. In the present study, we thus focused on two STEM educational domains mathematics and technical education. These are the only two STEM school subjects in Croatia that all students take through all upper grades of elementary school (5th through 8th grade). Focusing on mathematics is of additional importance since student outcomes in mathematics are crucial for later educational and career trajectories in STEM (Sadler, Sonnert, Hazari, \& Tai, 2012). Regarding technical education, although similar types of courses are taught in primary and secondary schools in other countries, we have found very little research on parenting influences in this domain. Thus, focusing on technical education in the present study presents a contribution to existing findings on the parent socialization in the STEM education.

This research is guided by the two models proposed by Eccles and her colleagues - the expectancy-value model (Eccles, 2005; Eccles et al., 1983; Eccles \& Wigfield, 2002) and the parent socialization model (Eccles, 1993; 2007). The expectancy-value model outlines the expectations for success and the subjective task value as the two key constructs that influence achievement, perseverance, effort, and activity choices in different areas (Eccles \& Wigfield, 
2002). Among competency beliefs, in addition to the expectations for success, the model outlines the self-concept of ability. While the expectation for success is defined as a person's belief in how successful they will be in a task in the near or far future, the self-concept of ability refers to an individual's assessment of their current competence in a particular area of activity (Eccles et al., 1983). However, research has shown that the self-concept of ability and expectation for success are saturated with the same factor and therefore can be treated as the same construct in research (Eccles, 2009; Eccles \& Wigfield, 1995). According to the expectancy-value model, the subjective task value has four components (Eccles, 2005; Eccles \& Wigfield, 2002). Attainment value can be defined as the personal meaning that an individual attaches to being successful in an activity. Interest or intrinsic value is defined as the enjoyment of engaging in an activity, while utility value refers to the extent to which the achievement domain is related to a person's present or future goals. In the empirical research, items measuring utility and attainment value are often combined into one measure called importance value (e.g., Viljaranta, Lazarides, Aunola, Räikkönen, \& Nurmi. 2015; Simpkins, Fredricks, \& Eccles, 2012; Watt et al., 2012). Finally, the perceived cost refers to the individual's perception of what they have to give up, and how much they have to invest to engage in an activity (Eccles, 2005).

Eccles' parent socialization model is embedded in the expectancy-value model. This model describes how family, and in particular parents, shape children's activity choices and achievement, primarily through influencing children's motivational beliefs (Simpkins, Fredricks, \& Eccles, 2015). The model outlines several groups of parental influences and a number of direct, indirect, and moderating relationships between these groups of variables (Eccles, 1993; Simpkins et al. 2015a). The distal mechanisms of parental influence are parental sociodemographic characteristics, such as parental education, financial status, occupation, and parental gender. According to the model, parental distal characteristics influence student outcomes primarily through their influence on parental beliefs and behaviours (Eccles, 2005). Research has found that children from families of lower socio-economic status (SES) achieve lower scores in the STEM school area (OECD, 2007) and are less likely to choose the advanced math and science courses (Bozick \& Ingels, 2008). The next set of constructs in the model are parental general beliefs and behaviours, such as gender stereotypes, efficacy beliefs, general and specific values, and educational styles. These beliefs are expected to directly influence parental child-specific beliefs (Wigfield et al., 2015). Parental distal characteristics and general practices may also act as moderators in the model. For example, it can be expected that because of the reduced financial and social resources, parents of lower SES can experience difficulties 
in translating their beliefs, values, and educational goals into appropriate educational practices (Eccles, 1993).

A prominent role in the model is given to parental child-specific beliefs, such as expectations for a child's achievement, perceptions of the child's abilities and interests, and perceptions of the value of a particular domain for the child. Studies have shown that parental evaluations of children's abilities in the STEM area predict students' motivational beliefs (Bhanot \& Jovanovic, 2009; Bleeker \& Jacobs, 2004; Frome \& Eccles, 1998; Jacobs \& Eccles, 1992) in this area. Parental child-specific beliefs have also been found to predict student achievement in STEM school subjects (Aunola, Nurmi, Lerkkanen, \& Rasku-Puttonen, 2003; Gill \& Reynolds, 1999). The model postulates that this relationship is primarily realized through the influence of parental child-specific beliefs on student motivation (Eccles, 2007). The power of parental child-specific beliefs in predicting student motivation and achievement is retained even when other relevant variables that may explain these associations are taken into account, such as student past achievement (Simpkins et al., 2015a). The model also assumes that through their child-specific beliefs, parents act as the "interpreters of reality". This means that children significantly rely on parental interpretations of the child's past performance as a relevant source for the self-assessment of their current abilities (Jacobs \& Eccles, 2000).

Finally, the model outlines different parenting behaviours, including role modelling, encouragement of a child's interests, provision of activity-related experiences, and parent-child coactivity (Simpkins et al., 2012). Research has found that all of these behaviours in the STEM domain can predict student outcomes related to STEM (e. g., Berkowitz et al., 2015; Jacobs \& Bleeker, 2004; Simpkins, Davis-Kean, \& Eccles, 2005). According to the parent socialization model, through their behaviours and practices, parents communicate to the child their values, beliefs, and goals in a certain activity domain (Eccles, 1993). Accordingly, two important mediational hypotheses emerge from the model: parenting behaviours should mediate the relationship between parental beliefs and children's motivational beliefs, and children's motivational beliefs should play a mediating role in the relationship between parents' and children's behaviours in a given area of activity (Simpkins et al., 2012).

Integrating student constructs from the expectancy-value model and parent constructs from the parent socialization model offers a wide view of parental influences in specific activity domains such as mathematics and technical education. Accordingly, in this research, we explored how parents shape student achievement and activity choices but also student academic motivation in these fields. This is important since the socialization of achievement motivation in specific activity domains has not been studied enough (Wigfield et al., 2015). 


\section{Research aims and problems}

The aim of this research was to examine the parental determinants of students' motivational beliefs, out-of-school activities, and achievement in mathematics and technical education, using theoretical assumptions and constructs specified in the expectancy-value model (Eccles et al., 1983; Eccles \& Wigfield, 2002) and the parent socialization model (Eccles, 1993; Simpkins et al., 2015a). The research attempted to address two broader problems. The first research problem was to test the conceptual model of parental determinants of student educational outcomes in mathematics and technical education. In the scope of this problem, we wanted to examine the direct and indirect relationships between distal and proximal parental influences and student educational outcomes in these two educational areas. The second research problem was to examine whether the relations assumed by the conceptual model differ with regard to the student gender and parental educational level.

\section{Methods}

\section{Participants}

A total of 1064 sixth- and seventh-grade students from 16 elementary schools in Zagreb and the surrounding area participated in this study. For each student, we also obtained the data from one of their parents or guardians. Thus, 1064 parents/guardians also participated in the study. In the student sample, there was an approximately equal number of girls (48\%) and boys (52\%) and sixth- (49\%) and seventh-grade (51\%) students. In the parental sample, $76.4 \%$ of parents were mothers and $19.1 \%$ of parents were fathers, while for 48 parents $(4.5 \%)$ the information on gender was missing.

\section{Measures}

Bearing in mind the theoretical framework, the operationalization of the constructs in this study largely followed the empirical work of Eccles and colleagues and most of the measures were adopted from the "Childhood and Beyond Study (CAB)" project (Eccles, Wigfield, \& Blumenfeld, 1984). Among parental variables, we measured parental educational level, parental child-specific beliefs in math and technical education, and parental behaviours in math and technical domain. To capture parental child-specific beliefs, parents had to report on their perceptions of a child's ability in the subject, their perception of the value of the subject for the child, and their perception of a child's effort and interest in the subject. Among parental 
behaviours, we measured parental role modelling in math and technical domains, parental encouragement of a child's interests in these domains, parents' involvement in student educational activities at home (i. e. homework assistance in math/technical education), and parental provision of STEM-related materials for the child. Among student motivational beliefs, we measured student self-concept of ability in math/technical education, interest in these school subjects, and attainment and utility value of these subjects. Items measuring attainment and utility value were combined in the measure of student importance value. Students also reported how often they engaged in out-of-school math and technical activities. We also obtained the information on student final grades in math and technical education and information on student gender and age cohort.

\section{Procedure}

The students completed the questionnaires in the paper-pen group testing during their regular classes in their school classrooms. Parental questionnaires were forwarded in open envelopes to parents via participating students. The parental questionnaire was intended to examine only one of the student's parents or guardians. Parents would send the completed questionnaire back to school in the sealed envelope, which could be opened only by the researchers. We collected two students' final grades in math and technical education from the school records. The control grades were collected in the school year preceding the student research - at the end of the fifth and sixth grades. As a criterion measure of student achievement, we used student final grades in math/technical education in the school year in which student research was conducted -at the end of sixth and seventh grades.

\section{Data analysis}

Structural equation modelling (SEM) was used to answer the first research problem. Two multigroup SEM analyses were performed to answer the second research problem.

\section{Results and discussion}

The test of the structural models revealed that the explored parental influences had a different role in explaining students' educational outcomes in mathematics and technical education. We expected that parent educational level will have an indirect effect on student outcomes through parental beliefs and behaviours. We mostly did not confirm these hypotheses. Our results point out that in the period of middle school, parents largely base their child-specific 
beliefs in math on the external information about the child's past math success, and that parental education does not have an independent contribution in shaping these beliefs. Previous research also shows that school grades are the most prominent source of information on which parents base their beliefs about their child's math abilities (Möller, Zimmermann, \& Köller, 2014; Tiedemann, 2000). When students' past achievement in technical education was taken into account, more educated parents had lower child-specific beliefs in this school subject. Parental education had a completely indirect negative effect on student self-concept of ability in technical education that was mediated through parental beliefs that were positively related to student self-concept. Parental education was also a direct negative predictor of student interest and the importance of technical education. These findings can be explained by the fact that in Croatian primary education, student outcomes in technical education have formal implications solely for the further orientation towards vocational secondary education and this educational path is less appealing to students and parents of higher SES backgrounds than to students and parents of lower SES (Meer, 2007). Parental education positively predicted parental provision of STEM materials but did not predict parental encouragement of a child's math interest, while in the technical domain this correlation was positive but very low. This result might be attributed to the fact that we did not measure the quality of parental encouragement. Furthermore, previous findings indicate that SES is reflected in parental educational behaviours with young children. For example, more educated parents are more likely to implement practices that develop basic mathematical skills in preschool children (Pan, Yang, Li, Liu, \& Liu, 2018).

In line with our hypotheses, parental beliefs were confirmed as moderate to strong, positive predictor of all student motivational beliefs in both math and technical education. This was also found in the previous research in the STEM area (e.g., Bhanot \& Jovanovic, 2009; Bleeker \& Jacobs, 2004). The predictive effect of parental beliefs in explaining student selfconcept of ability in the subject was stronger than the effect of student past achievement. In both subjects, we found a mediating effect of parental beliefs in explaining the link between student past achievement and later self-concept of ability. This finding confirms the role of parents as the "interpreters of reality". Parental beliefs were confirmed as significant predictors of later math achievement, even when student motivation and prior math achievement were controlled for. In technical education, parental beliefs had a marginal positive effect in predicting achievement, which can be attributed to the very low variability in student grades in technical education. Parental beliefs predicted student achievement in both subjects partially thorough higher student self-concept of ability in the subject. 
Parental beliefs predicted a higher level of parental encouragement in both domains, a higher level of provision of STEM materials, and a lower level of parental assistance in the child's coursework. However, the hypothesis about the mediational role of parental behaviours in explaining the relationship between parental and student beliefs mostly did not find support. This is because parental behaviours were week predictors of student motivation. This is in line with previous examinations of the parent socialization model (Eccles, 1993). Our finding may perhaps be attributed to the fact that we did not include quality measures of parental behaviours. Eccles (2007) argued that the socializing potential of parental behaviours depends on the motivational and emotional climate that parents create in their interactions with the child.

Regarding parental behaviours as predictors of student outcomes, significant differences were found depending on the type of behaviour and subject. Parental modelling did not predict any of the student outcomes in math. Parental modelling in the technical area positively predicted student interest in and importance of technical education. Parental modelling also positively predicted student engagement in out-of-school technical activities, through higher student value of technical education. Parents' technical activities may be more visible within everyday family interactions than math activities since technical activities involve the use of tools, objects, and machines. This would explain the different findings in the two domains.

Parental assistance in the student coursework in math was related to lower student interest in math and through lower interest to lower student engagement in math out-of-school activities. Previous research found that parental helping with math homework negatively predicted student achievement (Carmichael \& MacDonald, 2016; Robinson, 2014). If this type of parental involvement is motivated primarily by the child's poor performance, parents tend to apply more control which negatively affects the child's motivation (Silinskas \& Kikas, 2019). This may explain our findings, as parents were more likely to engage in their child's math coursework if they had lower beliefs about their child in math. This parental behaviour also mediated the relationship between lower parental child-specific beliefs in math and lower student math interest. This implies that this type of parental involvement communicates negative parental beliefs about the child's potential in math which can explain the contra-effect of this type of parental behaviour (Pomerantz, Moorman, \& Litwack, 2007). A small positive correlation was found between parental assistance in the student coursework in technical education and student importance value of this subject. This parental behaviour also had a small positive indirect effect on student engagement in technical activities through higher student importance value. This finding can be explained by the fact that parental beliefs were not related to this type of parental involvement in technical education. Thus, it seems that parents do not 
communicate low beliefs about the child's potential in technical education when engaging in this type of behaviour with the child. This may be because most students had high grades in technical education.

Out of all parenting behaviours, encouragement of a child's interest was the strongest predictor of student engagement in math and technical activities. According to Eccles (1993), one of the ways in which parental encouragement has a positive effect on student involvement in certain activities is the positive impact that such behaviour has on student motivational beliefs. This assumption was confirmed in our math model since parental encouragement in math predicted student engagement in math activities also indirectly - through a positive effect on student math interest. Parental provision of STEM materials was an insignificant predictor of student outcomes in both subjects. The presence of educational materials in the child's home does not imply that children actually use these materials in a way that promotes their motivation for the STEM educational domain. Furthermore, parents reported that their children had a relatively small number of STEM materials available at home, which could also explain our findings. Finally, parental provision of STEM materials may be more important for preschool children who still have not encountered educational materials through the regular education.

The established socialization mechanisms were equal for male and female children. Regarding the moderating effect of parental education, lower parental beliefs were associated with higher parental assistance in math coursework in both groups of parental education, but this association was stronger among parents who had higher education. Parental beliefs were also more strongly positively correlated with parental encouragement of the child's interest in mathematics among parents with higher education. Lack of educational, financial, and time resources can make it difficult for parents of lower SES to translate their socialization goals, beliefs, and values into adequate educational practices (Eccles, 1993; Spera 2006). Furthermore, parents who are more educated have stronger beliefs about their active role in their children's education and are more confident in their competencies to contribute to their child's academic achievement (Whitaker \& Hoover-Dempsey. 2013; Yamamoto, Holloway, \& Suzuki, 2016), which could also explain our findings in math.

\section{Conclusion}

Parental personal characteristics, beliefs, and behaviours had different roles in explaining student motivation, achievement, and activity choices in math and technical domain. The results indicate that both parent and student mediational mechanisms need to be taken into 
account to fully understand these processes. Furthermore, the mechanisms of parent socialization may differ depending on the socio-economic background of the family but also depending on the specific STEM discipline. These results reflect the complexity of socialization processes in the STEM area of education in the early adolescence. Thus, it is important to adopt a wide focus on family influences in this domain by examining multivariate models that will integrate multiple parental constructs and student educational outcomes. For a broader understanding of the socialization in the STEM area of education, more comparative research of multiple STEM disciplines is needed.

Key words: parental influences; socialization; mathematics; technical education; STEM education; educational outcomes 


\section{SADRŽAJ}

1. UVOD 1

1. 1. Važnost suvremenih istraživanja učeničkih obrazovnih ishoda u STEM području ................1

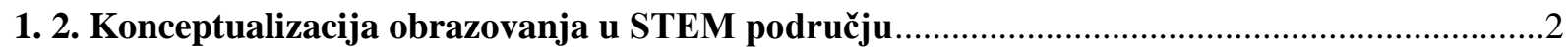

1. 2. 1. Obrazovanje u STEM području u Hrvatskoj i inozemstvu ..............................................2

1. 2. 2. Važnost heterogene konceptualizacije STEM područja u empirijskim istraživanjima ...5

1. 2. 3. Matematika i tehnička kultura kao kontekst istraživanja................................................5

1. 3. Učeničko postignuće i obrazovni odabiri u STEM području ..................................................

1. 3. 1. Važnost učeničkog postignuća u nastavnim predmetima u STEM području ...................7

1. 3. 2. Učenički obrazovni odabiri u STEM području..........................................................10

1. 3. 3. Učeničko sudjelovanje u izvanškolskim aktivnostima u STEM području ......................12

1. 4. Učenička motivacijska uvjerenja u STEM području .........................................................13

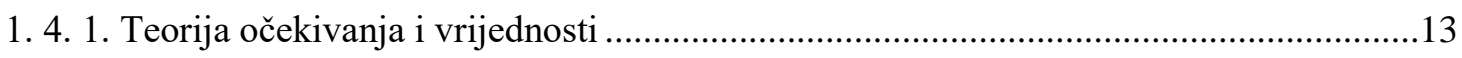

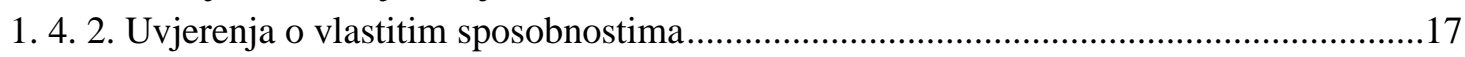

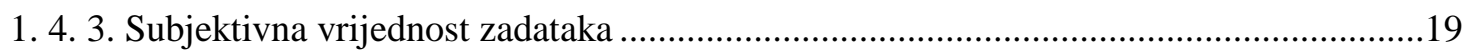

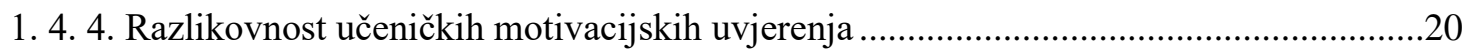

1. 4. 5. Dobne i rodne razlike u učeničkim motivacijskim uvjerenjima u STEM području ......22

1. 5. Odnos između učeničkih motivacijskih uvjerenja, obrazovnih odabira i postignuća............23

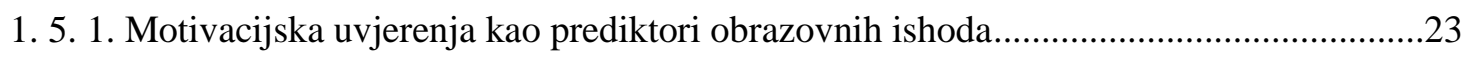

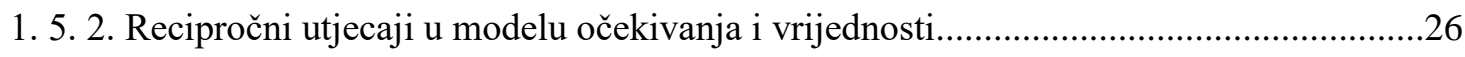

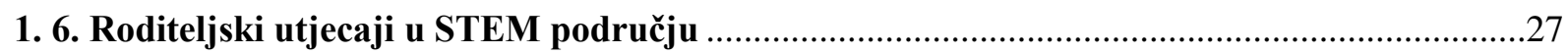

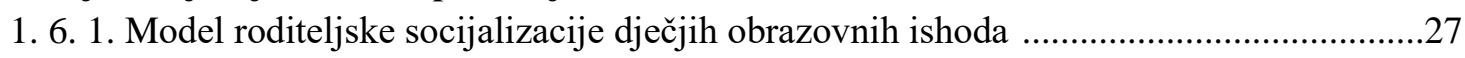

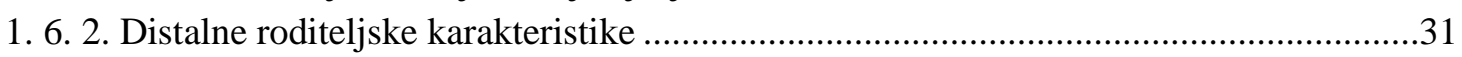

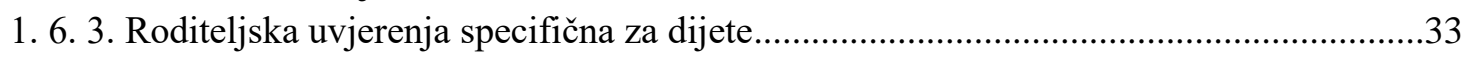

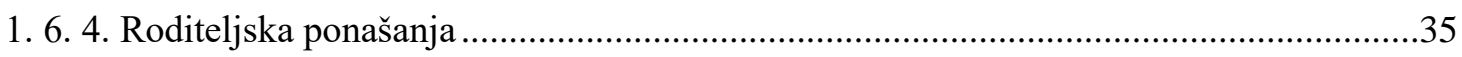

1. 6. 5. Odnos između roditeljskih uvjerenja i ponašanja u STEM području ............................40

1. 6. 6. Rodna diferenciranost roditeljskih uvjerenja i ponašanja u STEM području .................41

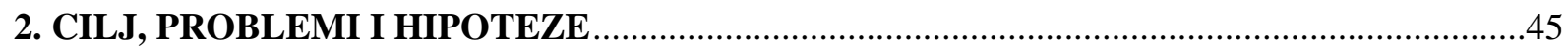

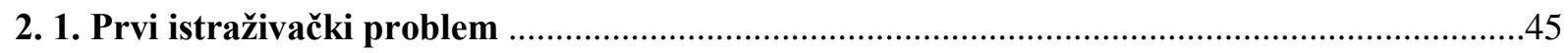

2. 1. 1. Hipoteze u području utjecaja distalnih roditeljskih karakteristika................................47

2. 1. 2. Hipoteze u području utjecaja roditeljskih uvjerenja specifičnih za dijete ......................47

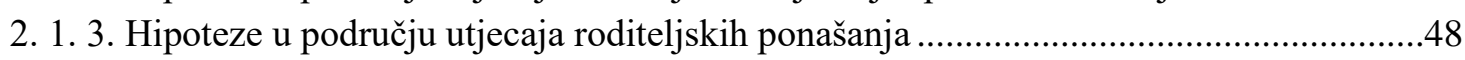

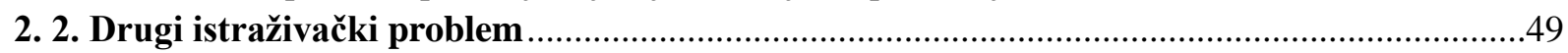

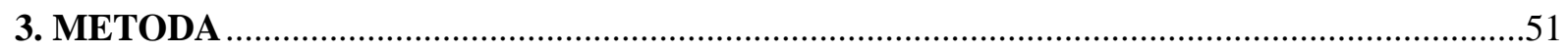

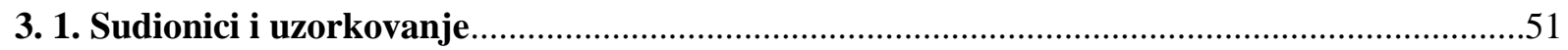

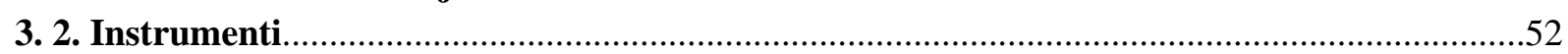

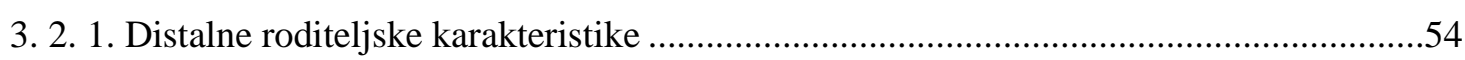

3. 2. 2. Roditeljska uvjerenja specifična za dijete u matematici i tehničkoj kulturi ..................54

3. 2. 3. Roditeljska ponašanja u području matematike i tehničke kulture .................................55

3. 2. 4. Učenička motivacijska uvjerenja u matematici i tehničkoj kulturi.................................57

3. 2. 5. Učeničke slobodne aktivnosti u matematičkom i tehničkom području ..........................58

3. 2. 6. Učeničko školsko postignuće u matematici i tehničkoj kulturi ...................................58

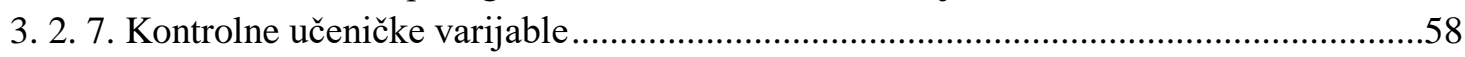

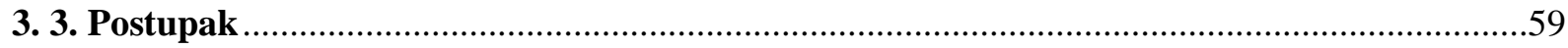

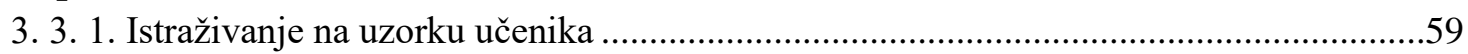

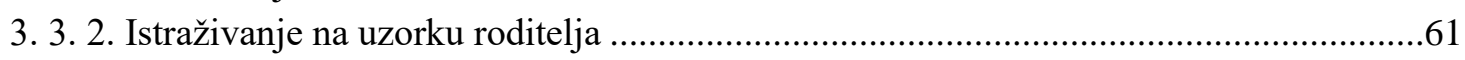




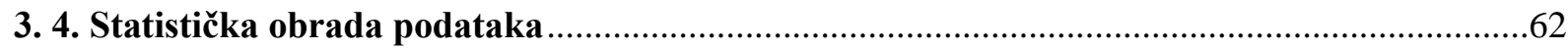

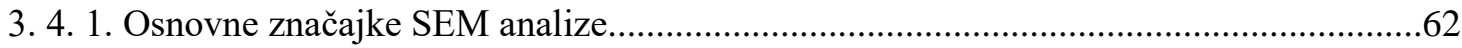

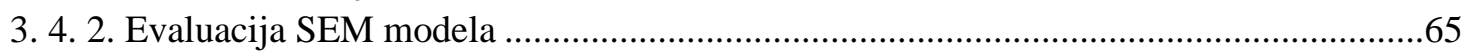

3. 4. 3. Ispitivanje izravnih i medijacijskih veza u SEM modelu ............................................67

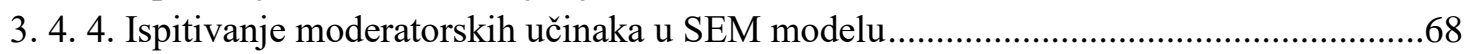

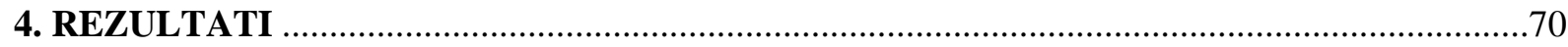

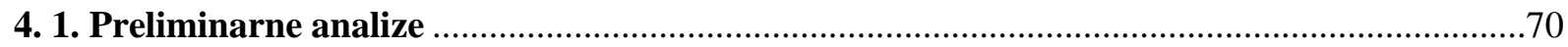

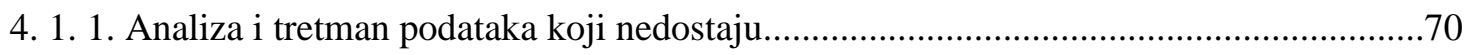

4. 1. 2. Deskriptivni podaci i povezanost varijabli korištenih u istraživanju..............................72

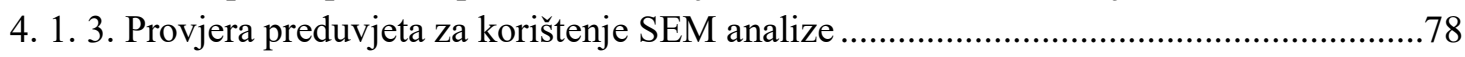

4. 2. Provjera modela roditeljskih odrednica učeničkih obrazovnih ishoda u matematici i tehničkoj kulturi

4. 2. 1. Provjera mjernih dijelova modela roditeljskih odrednica učeničkih obrazovnih ishoda u matematici i tehničkoj kulturi

4. 2. 2. Procjena izravnih puteva u strukturalnim modelima roditeljskih odrednica učeničkih obrazovnih ishoda u matematici

4. 2. 3. Procjena izravnih puteva u strukturalnim modelima roditeljskih odrednica učeničkih obrazovnih ishoda u tehničkoj kulturi

4. 2. 4. Usporedba relativnog doprinosa roditeljskih varijabli u objašnjavanju učeničkih obrazovnih ishoda u matematici i tehničkoj kulturi

4. 2. 5. Procjena neizravnih puteva u strukturalnim modelima roditeljskih odrednica učeničkih obrazovnih ishoda u matematici i tehničkoj kulturi...

4. 3. Provjera moderatorskih učinaka roda učenika i obrazovanja roditelja...............................105

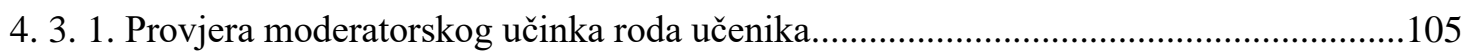

4. 3. 2. Provjera moderatorskog učinka obrazovanja roditelja ..............................................109

5. RASPRAVA

5. 1. Uloga obrazovanja roditelja u objašnjenju učeničkih obrazovnih ishoda u matematici i tehničkoj kulturi

5. 1. 1. Medijacijska uloga roditeljskih uvjerenja

5. 1. 2. Medijacijska uloga roditeljskih ponašanja

\section{2. Uloga roditeljskih uvjerenja u objašnjenju učeničkih obrazovnih ishoda u matematici i} tehničkoj kulturi

5. 2. 1. Roditeljska uvjerenja kao prediktori učeničkih motivacijskih uvjerenja.....................118

5. 2. 2. Roditeljska uvjerenja kao prediktori učeničkog postignuća ......................................119

5. 2. 3. Medijacijska uloga roditeljskih ponašanja

\section{3. Uloga roditeljskih ponašanja u objašnjenju učeničkih obrazovnih ishoda u matematici i} tehničkoj kulturi

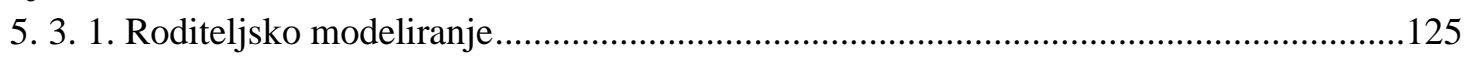

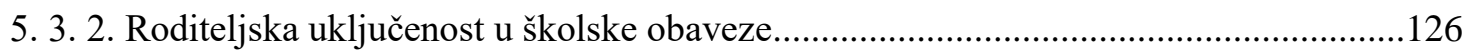

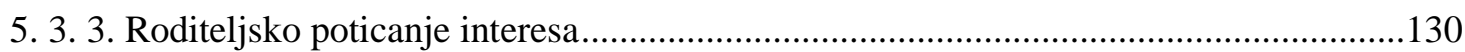

5. 3. 4. Roditeljsko pribavljanje obrazovnih materijala iz STEM područja ............................132

5. 4. Usporedba relativnog doprinosa roditeljskih varijabli u objašnjavanju učeničkih obrazovnih ishoda u matematici i tehničkoj kulturi .................................................................133

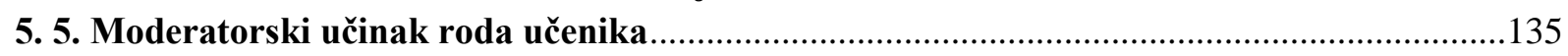

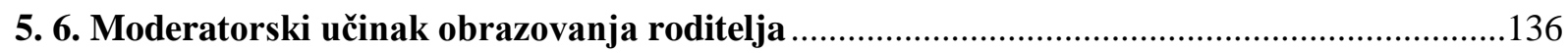

5. 7. Ograničenja istraživanja i preporuke za buduća istraživanja ............................................139

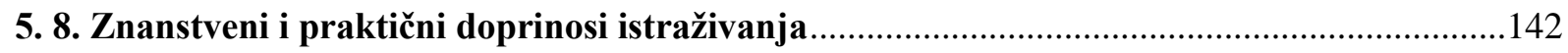

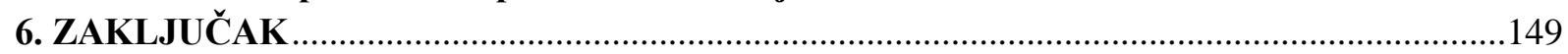


7. LITERATURA

152

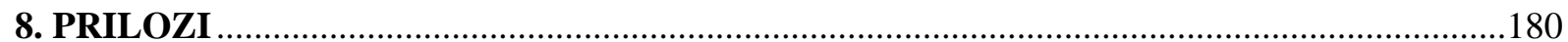

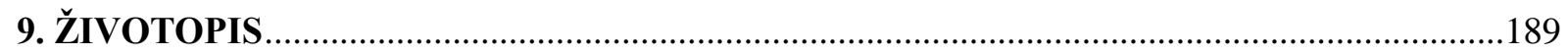




\section{UVOD}

\section{1. Važnost suvremenih istraživanja učeničkih obrazovnih ishoda u STEM području}

Akronim STEM (eng. Science, Technology, Engineering, Mathematics) predstavila je 2001. godine Judith Ramaley, tadašnja direktorica odjela za obrazovanje i ljudske resurse Američke zaklade za znanost. Akronim je uveden kako bi se njime referiralo na obrazovna područja prirodnih znanosti, tehnologije, inženjerstva i matematike (Breiner, Johnson, Harkness i Koehler, 2012). Međutim, od vremena kada je ovaj akronim usvojen nije prihvaćeno jedno, univerzalno određenje STEM područja te danas akronim ima različita značenja ovisno o kontekstu u kojem se koristi (Capraro, Capraro i Morgan, 2013; Roberts 2013). Američka zaklada za znanost STEM zapravo definira šire od disciplina koje označavaju slova akronima pa tako u STEM područje ubraja i društvene znanosti poput psihologije, ekonomije, sociologije i političkih znanosti (Green, 2007). Europski centar za razvoj strukovnog osposobljavanja u kategorizaciji STEM zanimanja navodi zanimanja u području prirodnih znanosti, inženjerstva te informacijskih i komunikacijskih tehnologija (Shapiro, Ostergaard i Hougaard, 2015). Međutim, u drugim međunarodnim izvještajima u STEM zanimanja se ubrajaju i zanimanja u području medicine i zdravstva (Shapiro i sur., 2015). Nacionalne politike u razvijenim zemljama su pak primarno usmjerene na poboljšanje STEM obrazovanja u područjima koja se odnose na užu definiciju STEM-a, tj. na matematiku, prirodne znanosti, inženjerstvo i tehnologiju (Kuenzi, Matthews i Mangan 2006; National Governors Association [NGA], 2007).

Bez obzira na njegovu konačnu operacionalizaciju, akronim STEM je danas široko korišten u znanstvenim, obrazovnim, gospodarskim i političkim raspravama. Naime, još od razdoblja Drugog svjetskog rata znanja i vještine u STEM području smatraju se ključnima za ekonomski napredak i konkurentnost svake države (Ritz i Fan, 2015). Danas se ovaj akronim najčešće koristi u kontekstu rasprava o nedostatku radne snage u STEM sektorima u brojnim zemljama svijeta. Primjerice, recentni podaci (European Centre for the Development of Vocational Training [Cedefop], 2016) pokazuju da u većini članica Europske unije trenutno postoji značajan nedostatak kvalificirane radne snage u STEM području, a posebice se to odnosi na stručnjake u industrijama informacijsko-komunikacijske tehnologije (tzv. ICT sektor). Kako bi se odgovorilo na rastuće potrebe tržišta za ovim radnim kadrom, u SAD-u je Vijeće savjetnika predsjednika za znanost i tehnologiju 2012. godine izdalo izvješće u kojem se kao nacionalni prioritet ističe potreba za školovanjem oko dodatnih milijun visokokvalificiranih stručnjaka u STEM području do 2022. godine (President's Council of Advisors on Science and 
Technology [PCAST], 2012). Nedavno istraživanje među poslodavcima u Ujedinjenom Kraljevstvu ukazalo je na raširenost problema regrutacije radne snage u STEM sektorima i to na svim razinama ekspertize - od početnika do iskusnih stručnjaka u području (Confederation of British Industry [CBI], 2015). Previđanja su da će u nekim STEM sektorima, kao što je računalni sektor, nerazmjer između potreba tržišta i broja dostupnih stručnjaka nastaviti rasti (Bureau of Labor Statistics, 2012). Globalna potreba za ovim radnim kadrom posljedica je, s jedne strane, pada broja ljudi koji se odlučuju za karijere u STEM području (Ramsey i Beathe, 2013; Watt i sur., 2012), a s druge strane, povećanja raznolikosti i broja radnih mjesta na kojima su potrebne vještine i znanja iz STEM područja (Franz-Odendaal, Blotnicky, French i Joy, 2016).

Opisani problemi se ne mogu promatrati odvojeno od problema i specifičnosti koji se vežu uz obrazovanje u STEM području. Naime, rana obrazovna iskustva koja se stječu već u osnovnoj školi određuju kasniji obrazovni, a time i profesionalni put pojedinca (Tai, Qi Liu, Maltese i Fan, 2006). Primjerice, odluka o odabiru fakulteta u STEM području kod mladih ljudi je uvelike uvjetovana njihovim iskustvima i postignućima mnogo prije upisa fakulteta (Astin i Astin, 1992). Stoga je istraživanje obrazovnih ishoda učenika u STEM području neophodno u kontekstu rješavanja tzv. „STEM problema“ na široj, gospodarskoj i društvenoj razini. Iz ovih razloga, mnoge svjetske vlade pokušavaju riješiti problem nedostataka radne snage u STEM području upravo kroz obrazovna istraživanja i obrazovne reforme u STEM području (Banks i Barlex, 2014).

\section{2. Konceptualizacija obrazovanja u STEM području}

\section{2. 1. Obrazovanje u STEM području u Hrvatskoj i inozemstvu}

U obrazovanju također nedostaje konsenzus oko toga kako odrediti STEM obrazovno područje. Xie, Fang i Shauman (2015) kao jedan od načina na koji se može prevladati konceptualna neodređenost STEM obrazovanja navode što jasniju operacionalizaciju STEM obrazovnog područja u empirijskim istraživanjima. Većina obrazovnih istraživanja koja se bave STEM područjem orijentirana je specifično na matematiku i prirodoslovlje (National Research Council [NRC], 2011). S druge strane, mnogo je manje istraživanja vezanih uz obrazovanje u području tehnologije i inženjerstva. Razlog tome se može pripisati činjenici da se ovi sadržaji najčešće ne poučavaju u obliku nastavnih predmeta u osnovnoj i srednjoj školi (NRC, 2009) te je nastava iz STEM područja u velikoj mjeri usmjerena upravo na matematiku i prirodoslovlje 
(English, 2015). Također, obrazovne politike u STEM području su primarno usmjerene na matematiku i prirodoslovlje (Bell, 2016).

O definiciji STEM obrazovnog područja danas se najčešće raspravlja unutar tri okvira (Radloff i Guzey, 2016): (1) STEM kao metoda poučavanja; (2) STEM kao skup povezanih ili integriranih disciplina; te (3) određenje STEM-a koje ovisi o pojedinim interesnim skupinama ili o specifičnom kontekstu unutar kojeg se STEM obrazovanje razmatra i konceptualizira. Nastavno na prvi okvir, pojedini se autori umjesto na tradicionalno bavljenje sadržajem STEM područja, više usmjeravaju na način razmišljanja i vještine koje su karakteristične za STEM područje. Prema njima je STEM specifični način poučavanja kojeg obilježava usvajanje koncepata znanstvenog istraživanja, tehnološkog i inženjerskog dizajna, matematičke analize te uvođenje interdisciplinarnih tema i vještina koje su nužne u 21. stoljeću (Johnson, 2013). STEM poučavanje se također definira kao interdisciplinarni pristup kroz koji se obrazovni koncepti povezuju s primjerima iz stvarnog života, čime se ostvaruju poveznice između škole, zajednice te svijeta rada i poduzetništva (Tsupros, Kohler i Hallinen, 2009).

Kada govorimo o sadržaju STEM obrazovnog područja, postoje značajne razlike s obzirom na razinu obrazovanja (Breiner i sur., 2012) i nacionalni kurikulum (Ritz i Fan, 2015). Ove se razlike ponajviše odnose na osnovnoškolsko i srednjoškolsko obrazovanje. U američkom predtercijarnom obrazovnom sustavu STEM obrazovno područje je do šestog razreda $^{1}$ sinonim za kurikulum nastavnih predmeta matematike i prirodoslovlja (eng. science) koji su obavezni za sve učenike (Xie i sur., 2015). Na višim razinama obrazovanja STEM kurikulum postaje sve više specijaliziran. Primjerice, u periodu između osmog i dvanaestog razreda $^{2}$ američki učenici mogu birati između različite razine složenosti kurikuluma iz matematike i prirodoslovlja. Postsekundarno obrazovanje je u SAD-u, kao i u većini zemalja, organizirano kao slijed kolegija u jednom području koje se može definirati kao STEM ili neSTEM područje (Xie i sur., 2015). Međutim, unutar postsekundarnog obrazovanja u nekoj od STEM disciplina obrazovna iskustva i obrazovni ishodi studenata mogu uvelike varirati pa bi istraživači trebali razlikovati između pojedinih disciplina koje se mogu svrstati u postsekundarno obrazovanje u STEM području (Xie i Killewald, 2012).

U Hrvatskoj se na razini osnovnoškolskog odgoja i obrazovanja STEM sadržaji poučavaju primarno u okviru matematičkog, prirodoslovnog te tehničkog i informatičkog područja kurikuluma (Ministarstvo znanosti i obrazovanja [MZO], 2017a). Unutar ovih

\footnotetext{
${ }^{1} \mathrm{U}$ američkom obrazovnom sustavu učenici koji polaze šesti razred su najčešće dobi između 11 i 12 godina. ${ }^{2} \mathrm{U}$ američkom obrazovnom sustavu učenici su u ovom periodu obrazovanja najčešće u dobi između 14 i 18 godina.
} 
područja poučavaju se nastavni predmeti matematika (kroz svih osam razreda), priroda i društvo (u prva četiri razreda), priroda (u petom i šestom razredu), geografija i tehnička kultura (od petog do osmog razreda) te biologija, fizika i kemija (u sedmom i osmom razredu). Posljednjih dvadesetak godina se informatika u hrvatskim osnovnim školama poučavala kao izborni predmet, međutim, 2018. godine uvedena je kao obavezni predmet u petom i šestom razredu osnovne škole (MZO, 2018b). U sedmom i osmom razredu informatika se može slušati kao izborni predmet, a predviđeno je da od školske godine 2020./21. informatika postane izborni predmet i u nižim razredima osnovne škole. U hrvatskom srednjoškolskom sustavu obrazovanje iz STEM područja postaje više specijalizirano budući da učenici mogu birati između škola s različitim udjelom STEM nastavnih sadržaja. Pritom je dostupan veliki broj strukovnih srednjih škola koje pripremaju učenike za rad u specifičnim područjima STEM djelatnosti. Takve škole spadaju u obrazovna područja kao što su Elektrotehnika i računalstvo, Graditeljstvo i geodezija, Strojarstvo, brodogradnja i metalurgija, Geologija, rudarstvo, nafta i kemijska tehnologija (MZO, 2013). Unutar gimnazijskih programa STEM sadržaji se poučavaju kroz nastavne predmete matematike, biologije, kemije, fizike, geografije i informatike. Pritom je naglasak, kao i u osnovnoj školi, stavljen na matematiku koja se poučava u najvećoj satnici (MZO, 1994). Međutim, satnica iz matematike, ali i ostalih nastavnih predmeta iz STEM područja, u srednjoj se školi značajno razlikuje s obzirom na konkretan program. Primjerice, unutar gimnazijskih programa, satnica matematike je najveća u prirodoslovno-matematičkim, a najmanja u jezičnim gimnazijama (MZO, 2018a).

U Hrvatskoj, za razliku od brojnih drugih zemalja, ne postoji integrirano poučavanje prirodoslovnih predmeta. U posljednje se pak vrijeme u izvješćima prominentnih znanstvenih organizacija poziva na u potpunosti integrirano poučavanje STEM sadržaja u osnovnoj i srednjoj školi (National Academy of Engineering and National Research Council, 2014). Međutim, učinkovitost takvog obrazovanja za učeničko usvajanje ključnih STEM sadržaja je slabo istražena (Barrett, Moran i Woods, 2014; Honey, Pearson i Schweingruber, 2014). Ipak, u brojnim zemljama već postoji određena razina integracije nastavnih predmeta iz STEM područja. Najčešće je ta integracija prisutna u obliku objedinjenog obrazovanja iz predmeta prirodoslovlje koji se, primjerice, poučava u SAD-u i Engleskoj (Tripney i sur., 2010). U Francuskoj, Izraelu i Nizozemskoj postoji objedinjeno obrazovanje iz područja prirodoslovlja i tehnologije (Moon, Brown i Ben-Peretz, 2000). U Kanadi, SAD-u i Švedskoj sadržaji vezani uz inženjerstvo su integrirani u obrazovni kurikulum u tehnološkom području (Ritz i Fan, 2015). U Aziji je korejski obrazovni sustav 2011. godine kao jedno obrazovno područje uveo poučavanje sadržaja iz prirodoslovlja, tehnologije i osnova ekonomije (Kim, 2011). 


\section{2. 2. Važnost heterogene konceptualizacije STEM područja u empirijskim istraživanjima}

Iako u brojnim zemljama svijeta postoji određena razina integriranog poučavanja STEM sadržaja, pokazalo se da je u empirijskim istraživanjima poželjno STEM promatrati kao heterogeno područje. U prilog tome, primjerice, govore nalazi rijetkih istraživanja koja su obuhvatila zasebne nastavne predmete iz STEM područja te pritom ukazala na diferencijaciju učeničkih motivacijskih uvjerenja u tim predmetima (npr. Simpkins, Price i Garcia, 2015). Potreba za heterogenom konceptualizacijom STEM područja ponajviše je do sada dokazana u istraživanjima rodnih razlika u STEM-u. Primjerice, američki nacionalni podaci pokazuju da je najveći rodni disparitet u obrazovnim odabirima u STEM području prisutan u fizici te posebice u području inženjerstva, gdje su žene značajno podzastupljene. S druge strane, žene predvode u broju dodijeljenih diploma iz bioloških znanosti (Mann i DiPrete, 2013).

Važnost heterogene konceptualizacije STEM područja u empirijskim istraživanjima je vidljiva i u ispitivanju drugih važnih prediktora obrazovnih i profesionalnih ishoda učenika. Primjerice, u nedavnom se istraživanju na hrvatskom uzorku pokazalo da su učenički profesionalni interesi u području prirodoslovlja u velikoj mjeri povezani $\mathrm{s}$ učeničkim prethodnim postignućem u nastavnim predmetima STEM obrazovnog područja (Šimunović i Babarović, u tisku). S druge strane, nije pronađena povezanost između učeničkog postignuća u nastavnim predmetima STEM područja i učeničkog interesa za zanimanja u području inženjerstva i tehnologije. Iako empirijski rezultati, dakle, upućuju na važnost ispitivanja različitih STEM disciplina, takav je istraživački pristup relativno rijetko zastupljen (Su i Rounds, 2015). Posebice je to vidljivo u području kojim se bavi ovaj rad, odnosno, u istraživanjima roditeljskih odrednica učeničkih obrazovnih ili vokacijskih ishoda u STEM području, gdje su istraživanja najčešće usmjerena na samo jednu STEM disciplinu (npr. Bhanot i Jovanovic, 2009; Denner, 2011; Simpkins, Fredricks, i Eccles, 2012) ili na cjelovito STEM područje, bez uvida u zasebne discipline (npr. Nugent i sur., 2015; VanMeter-Adams, Frankenfeld, Bases, Espina i Liotta, 2014).

\section{2. 3. Matematika i tehnička kultura kao kontekst istraživanja}

Imajući u vidu prethodno prikazane nalaze, čini se važnim ispitati jesu li pojedini mehanizmi roditeljskih utjecaja invarijantni kroz različite STEM discipline. Ovakav je pristup još više opravdan ako u obzir uzmemo hrvatski obrazovni kontekst u kojem ne postoji integrirano poučavanje STEM sadržaja. Stoga je moguće i da se roditeljski utjecaji međusobno 
razlikuju s obzirom na konkretan nastavni predmet. Ovo je istraživanje usmjereno na matematiku i tehničku kulturu kao jedina dva predmeta STEM obrazovnog područja u Hrvatskoj koja svi učenici polaze kroz sve više razrede osnovne škole. Provjera istraživačkih problema u području matematike ima dodatnu važnost budući da su učenička motivacija i postignuće u matematici krucijalni za kasniji odabir obrazovanja i zanimanja općenito u STEM području (National Science Board [NSB], 2010; Sadler, Sonnert, Hazari i Tai, 2012). Što se tiče predmeta tehničke kulture, iako u inozemstvu postoje slični tipovi nastavnih predmeta (npr. predmet Dizajn i tehnologija koji se poučava na svim razinama osnovne i srednje škole u Engleskoj), pregledom literature nismo pronašli istraživanja koja su se bavila roditeljskim utjecajima ili međuodnosom učeničkih obrazovnih ishoda u ovom obrazovnom području. S druge strane, razina apstraktnosti sadržaja koji se poučavaju u tehničkoj kulturi je evidentno manja nego u matematici i prirodoslovnim predmetima koji ujedno predstavljaju nastavne predmete STEM obrazovnog područja unutar kojih se dominantno istražuju relevantni roditeljski utjecaji (npr. Acosta i Hsu, 2014; Bleeker i Jacobs, 2004; Breakwell i Beardsell, 1992).

Iz ovih se razloga čini istraživački vrijednim provjeriti vrijede li odnosi koji će biti ispitani u ovom istraživanju u jednakoj mjeri u području matematike i tehničke kulture. Pritom treba imati na umu određene razlike između ova dva predmeta koje mogu predstavljati relevantne čimbenike u pogledu stabilnosti modela roditeljskih utjecaja koji će biti ispitan u ovom istraživanju. Naime, matematika je jedan od najvažnijih predmeta i u osnovnoškolskom i u srednjoškolskom obrazovanju u Hrvatskoj te obrazovno postignuće u matematici ima vrlo važne reperkusije za obrazovni put učenika, o čemu će biti više riječi u kasnijim poglavljima. S druge strane, tehnička kultura je u mnogo manjoj mjeri zastupljena u našem obrazovanju. Godišnja satnica matematike u svim razredima osnovne škole iznosi 140 sati, odnosno četiri sata tjedno (MZO, 2018a), dok se nastava tehničke kulture izvodi samo u višim razredima osnovne škole i to sa značajno manjom satnicom - 35 sati godišnje, odnosno, jedan sat tjedno (MZO, 2018a). Nadalje, matematika je predmet koji je zastupljen u svim srednjim školama (Nacionalni centar za vanjsko vrednovanje obrazovanja [NCVVO], 2015), dok se tehničkotehnološki nastavni predmeti provode samo u pojedinim strukovnim srednjim školama. Naposljetku, ispit iz matematike obavezni je dio državne mature (MZO, 2012) te se vrednuje za upis na većinu fakulteta. S obzirom na stalnu prisutnost i istaknutu važnost koja se pridaje matematici tijekom osnovnoškolskog i srednjoškolskog obrazovanja, može se očekivati da škola ima istaknutu ulogu u učeničkom usvajanju matematičkih vještina i razvoju motivacije za matematiku. Ovaj se zaključak može povezati i s nalazima inozemnih istraživanja. 
Primjerice, Simpkins i suradnice (2012) su utvrdile da roditelji imaju manju važnost u socijalizaciji učeničkih motivacijskih uvjerenja i odabira aktivnosti u području matematike u usporedbi s područjima glazbe i sporta, gdje je utjecaj roditelja bio značajno snažniji. Autorice ovaj nalaz pripisuju upravo činjenici da matematika predstavlja središnji dio obrazovnog kurikuluma, dok su sport i glazba manje zastupljeni u nastavnim sadržajima pa roditeljski utjecaji mogu imati istaknutiju ulogu u socijalizaciji učeničkih ishoda u tim područjima. Sljedeći ove pretpostavke, zanimljivo je pitanje provjeriti razlikuju li se pojedini mehanizmi roditeljskih utjecaja i u dva nastavna predmeta STEM područja čija je istaknutost u obaveznom obrazovanju u Hrvatskoj vrlo različita. Empirijski nalazi koji će biti prikazani u kasnijim dijelovima ovog uvoda odnosit će se na istraživanja iz različitih nastavnih predmeta STEM područja, s naglaskom na nalaze u području matematike. Naime, osim što je jedno od dva područja uključena u ovo istraživanje, matematika je nastavni predmet iz STEM područja u kojem postoje najopsežniji empirijski nalazi vezani uz probleme kojima se bavi ovaj rad. S druge strane, kao što je već bilo riječi, nismo pronašli istraživanja koja su se bavila područjem istraživanja u tehničkom obrazovanju.

\section{3. Učeničko postignuće i obrazovni odabiri u STEM području}

\section{3. 1. Važnost učeničkog postignuća u nastavnim predmetima u STEM području}

Postignuće učenika u nastavnim predmetima STEM područja vrlo je važno u kontekstu rasprava o obrazovnim i profesionalnim odabirima mladih ljudi. Školsko postignuće u matematici i prirodnim predmetima posebice je važno u višim razredima osnovne škole, kada su učenici u dobi između 10 i 14 godina budući da školski uspjeh u ovoj dobi uvelike određuje izbor srednje škole, a time dugoročno i pristup visokoškolskom obrazovanju i kasnijim profesionalnim mogućnostima (Reynolds, 1991). Uspjeh u nastavnim predmetima STEM područja u višim razredima osnovne škole ima dodatnu važnost u obrazovnim sustavima kao što je američki, u kojima učenici u skladu sa svojim postignućem mogu birati različitu razinu složenosti nastavnih predmeta STEM područja u srednjoj školi (Singh, Granville i Dika, 2002). U hrvatskom obrazovnom sustavu postignuće u predmetima STEM područja postaje po prvi put važno za učenički obrazovni i profesionalni put pri prelasku iz osnovne u srednju školu. Naime, osim prosjeka zaključnih ocjena iz svih nastavnih predmeta, za upis u sve srednjoškolske programe u Hrvatskoj, izuzev strukovnih programa koji traju manje od tri godine, dodatno se vrednuje i postignuće iz hrvatskog jezika, matematike i prvog stranog jezika 
u posljednje dvije godine osnovnog obrazovanja (MZO, 2013). Time se ističe važnost matematike kao ključnog STEM predmeta u osnovnoj školi. Pored toga, za upis u veliki broj srednjoškolskih programa u Hrvatskoj dodatno se boduje postignuće u posljednja dva razreda osnovne škole u dodatnim STEM predmetima osim matematike. Od ukupno 153 četverogodišnja srednjoškolska programa koja su dostupna u Hrvatskoj, postignuće u fizici se boduje za upis u 58 programa, postignuće u kemiji za upis u 53 programa, postignuće u biologiji za upis u 38 programa te postignuće u tehničkoj kulturi za upis u 35 programa (MZO, 2013). Postignuće u dodatnim predmetima STEM područja vrednuje se za upis u većinu neumjetničkih strukovnih programa te za upis u prirodoslovne i prirodoslovno-matematičke gimnazije (MZO, 2013).

Kada govorimo o ulasku u sustav visokog obrazovanja, u Hrvatskoj je za upis na sva javna visoka učilišta nužno polaganje ispita državne mature. Osim toga, fakulteti u Hrvatskoj boduju i prosjek ocjena tijekom srednje škole. Matematika se i u ovoj fazi obrazovne tranzicije ističe se kao ključan nastavni predmet STEM područja budući da je upravo ispit iz matematike, pored ispita iz hrvatskog jezika te stranog jezika, obavezan dio državne mature. Pritom učenici mogu odabrati hoće li polagati ispite na višoj ili osnovnoj razini (MZO, 2012). Za upis na veliki broj fakulteta koji su STEM usmjerenja, kao što su fakulteti u tehničkom i prirodoslovnom području, potrebno je polaganje više razine ispita iz matematike. Pored toga, za upis na mnoge fakultete STEM usmjerenja traži se i polaganje izbornih ispita iz državne mature iz različitih nastavnih predmeta STEM područja (Nacionalni informacijski sustav prijave na visoka učilišta, 2019). U tom smislu vještine i znanja koje je učenik stekao u STEM obrazovnom području tijekom srednje škole u velikoj mjeri određuju njegov pristup visokom obrazovanju u STEM području.

Ovdje treba naglasiti da su vještine i znanja u STEM području važne za sve učenike, a ne samo za učenike koje zanima kasnije obrazovanje i karijera u ovom području. Naime, zbog ubrzanog tehnološkog i znanstvenog razvoja, u 21. stoljeću je STEM pismenost ključna za građansku uključenost, financijsku produktivnost i donošenje informiranih osobnih i društvenih odluka (NRC, 2011). Međutim, istraživanja pokazuju da veliki broj učenika ostvaruje nisku razinu znanja i vještina u STEM području. Primjerice, rezultati velikog nacionalnog istraživanja koje je 2011. godine provedeno u SAD-u, pokazali su da je čak 65\% učenika osmih razreda osnovne škole ostvarilo najnižu kategoriju postignuća na standardiziranom testu znanja i sposobnosti iz prirodoslovlja, $35 \%$ učenika drugu razinu postignuća, a samo $2 \%$ učenika treću, naprednu razinu postignuća (National Center for Educational Statistics [NCES], 2012). Europska komisija u svom je izvješću iz 2013. godine upozorila da čak 20\% učenika u Europi 
nema osnovnu razinu matematičke i prirodoslovne pismenosti (European Commission [EC], 2013). Komisija je naglasila da je ovaj nalaz alarmantan s obzirom da je „kultura znanosti i znanstvenog načina kritičkog propitkivanja ključna pretpostavka dobrog funkcioniranja tehnološki i politički složenog demokratskog društva“ (EC, 2013, str. 3). Europska komisija također upozorava da se većina članica Europske unije u svojim obrazovnim politikama ne bavi niskim postignućem učenika u STEM obrazovnom području.

Posljednjih se nekoliko desetljeća primjenjuju i međunarodni standardizirani testovi znanja i vještina u STEM obrazovnim područjima. Rezultati tih testiranja također pokazuju da su mnoge razvijene zapadne zemlje, poput SAD-a i Njemačke, suočene s relativno niskim postignućem svojih učenika u STEM obrazovnom području (Neumann, Kauertz i Fischer, 2012). Jedno od najpoznatijih takvih istraživanja je Međunarodni program za procjenu znanja i vještina učenika (Programme for International Student Assessment - PISA) kojeg od 1997. godine, u trogodišnjim ciklusima, provodi Organizacija za ekonomsku suradnju i razvoj (OECD) (Braš Roth, 2016). Ovo istraživanje uključuje učenike u dobi od 15 godina te se osim čitalačke pismenosti ispituje i pismenost iz matematike i prirodoslovlja. U istraživanju provedenom 2015. godine prirodoslovne kompetencije su ispitivane kao glavno područje. U Hrvatskoj je tada u istraživanju sudjelovalo 6754 učenika iz 158 srednjih i dvije osnovne škole. Rezultati pokazuju da je u Hrvatskoj učeničko postignuće u prirodoslovlju niže u odnosu na međunarodni prosjek. Naime, 2015. godine Hrvatska se po postignuću na testu prirodoslovne pismenosti od 72 uključene zemlje našla na 37. mjestu. Dodatno zabrinjava nalaz da je u usporedbi s rezultatima iz 2006. godine prosječni rezultat hrvatskih učenika značajno pao te se on također svake tri godine pogoršava za otprilike pet bodova (Braš Roth, 2016). Međutim, treba napomenuti da analiza rezultata prošlih PISA ciklusa pokazuje da u većini uključenih zemalja od 2006. godine nije došlo do povećanja učeničkih kompetencija u prirodoslovnom području ili je čak došlo do njihovog pogoršanja, kao što je to slučaj u Hrvatskoj (Braš Roth, Markočić Dekanić i Markuš Sandrić, 2017). Od 2006. godine je također vidljiv kontinuitet u povećanju proporcije učenika u Hrvatskoj koji na skali prirodoslovne pismenosti ne dostižu drugu razinu, što znači da ne posjeduju osnovna prirodoslovna znanja i vještine potrebne za svakodnevni život. Prema rezultatima iz 2015. godine takav rezultat je postiglo čak $24,7 \%$ hrvatskih učenika (Braš Roth, 2016). U PISA istraživanju matematičke pismenosti Hrvatska je 2015. godine također ostvarila ispodprosječni rezultat te se našla na 41. mjestu od 72 uključene zemlje. Pritom čak 32\% hrvatskih učenika nije ostvarilo drugu razinu postignuća koja ukazuje na ovladavanje osnovnom razinom matematičkih znanja i vještina (Braš Roth, 2016). 
Istraživanja na postsekundarnoj razini obrazovanja također ukazuju na nedostatne kompetencije studenata koji studiraju u STEM području. Pokazalo se da studenti često nemaju osnovno razumijevanje ključnih STEM sadržaja prije završetka studija (Bao i sur., 2009; Smith i Knight, 2012). Inozemna istraživanja ukazuju i na značajne razlike u postignuću u STEM obrazovnom području između različitih demografskih skupina. Tako je poznato da Afroamerikanci i Latinoamerikanci postižu niže rezultate u STEM obrazovnom području od bijelaca i azijskih Amerikanaca (Hemphill i Vanneman, 2011; Hill i Green, 2007). Učenici nižeg socioekonomskog statusa (SES) postižu niže rezultate u nastavnim predmetima STEM područja nego učenici višeg SES-a (Duncan i Magnuson, 2011). Ove su razlike u velikoj mjeri stabilne (Morgan, Farkas, Hillemeier i Maczuga, 2016).

S obzirom na dalekosežne implikacije koje postignuće u STEM obrazovnom području ima za obrazovni i profesionalni put učenika, ali i za uspješno funkcioniranje svih mladih ljudi, istraživanja se trebaju orijentirati na identifikaciju individualnih i kontekstualnih čimbenika koji određuju ovo postignuće. To je dodatno važno uzmemo li u obzir nalaze da su mnoge svjetske zemlje suočene s relativno niskim kompetencijama učenika u STEM području.

\section{3. 2. Učenički obrazovni odabiri u STEM području}

Učeničke odabire u STEM području moguće je promatrati kroz različite razine obrazovnog i profesionalnog puta. Kao što je već bilo riječi, u nekim zemljama učenici prelaskom u više razrede osnovne škole biraju razinu složenosti nastavnih predmeta STEM područja. Međutim, istraživanja u ovim zemljama ukazuju na pad udjela učenika koji se odlučuju za složenije nastavne predmete u STEM području (Bøe, Henriksen, Lyons i Schreiner, 2011; Lyons i Quinn, 2010). U hrvatskom osnovnoškolskom sustavu učenici koji pokazuju izraziti interes i sposobnosti za određene nastavne predmete STEM područja mogu odabrati polaziti dodatnu nastavu iz tih predmeta. Međutim, učenici u Hrvatskoj nemaju mogućnost sukladno svojim afinitetima usmjeriti se k složenijim STEM sadržajima kroz izbor razine složenosti obaveznih predmeta ili kroz odabir izbornih predmeta u STEM području. Izuzetak je informatika koja se tek odnedavno kao izborni predmet može slušati u sedmom i osmom razredu osnovne škole.

Prelaskom u srednju školu učenici u Hrvatskoj mogu se jasnije usmjeriti prema STEM području. Primjerice, učenici koji se odluče za gimnazijski program mogu se prema STEM području usmjeriti kroz upis prirodoslovno-matematičkog ili prirodoslovnog gimnazijskog programa. Učenici koji se ne odluče za gimnazijski program mogu se prema STEM području 
usmjeriti kroz izbor različitih strukovnih srednjih škola koje pružaju osposobljavanje za zanimanja u STEM području. Međutim, ovdje treba napomenuti da u kontekstu hrvatskog obrazovnog sustava, izbor srednje škole vjerojatno nije najbolji indikator učeničkih odabira vezanih uz STEM područje. Naime, mnogi učenici koji se u Hrvatskoj odluče za srednjoškolsko obrazovanje koje nije u STEM području, kao što je primjerice program opće gimnazije, kasnije odabiru i uspješno ulaze u visoko obrazovanje u nekom od STEM polja. Primjerice, učenici različitih gimnazijskih programa u Hrvatskoj čine većinu upisanih studenta na sveučilišne studijske programe iz područja tehničkih te posebice iz područja prirodnih znanosti (Jokić i Ristić Dedić, 2014).

Rezultati velike analize koju su proveli Jokić i Ristić Dedić 2014. godine daju uvid u odabire hrvatskih učenika na razini visokog obrazovanja u STEM području. Ova se analiza temeljila na rezultatima ispita državne mature te podacima vezanim uz prijavu i odabire studijskih programa u akademskim godinama od 2010./2011. do 2013./2014. Različite kategorije dobivenih rezultata ukazuju na relativno nisku poželjnost sveučilišnih studijskih programa koji spadaju u temeljne STEM znanstvene discipline među hrvatskim učenicima. Primjerice, kada se u obzir uzme omjer broja kandidata koji su postavili određeni sveučilišni studijski program ili kategoriju programa kao svoj prvi odabir i broja upisnih mjesta na tom programu, sveučilišni programi u područjima biotehničkih, tehničkih i prirodnih znanosti imali su relativno nisku razinu poželjnosti među učenicima. Kada se u obzir uzmu izdvojeni sveučilišni programi, kroz sve su četiri analizirane godine najpoželjniji programi bili u manjim znanstvenim i umjetničkim poljima poput logopedije, filmske i kazališne umjetnosti. Među 15 najpoželjnijih polja našle su se tri polja iz područja tehničkih znanosti - arhitektura i urbanizam, geodezija i građevinarstvo, ali samo jedno polje iz prirodnih znanosti - biologija. Među 15 najmanje poželjnih sveučilišnih studijskih programa čak je njih 13 bilo iz područja prirodnih, tehničkih ili biotehničkih znanosti (Jokić i Ristić Dedić, 2014).

Podaci za Europsku uniju pokazuju da je 2016. godine najzastupljenije područje studiranja u Europskoj uniji uključivalo studije izvan STEM područja, odnosno, studije vezane uz društvene znanosti, novinarstvo, informacije, poslovanje, administraciju ili pravo. Gotovo je jedna trećina svih studenata u Europskoj uniji 2016. godine studirala u nekom od ovih područja (Eurostat, 2018). Iako je drugo najzastupljenije područje studiranja uključivalo studije iz STEM područja, tj. studije u području inženjerstva, prerađivačke industrije te studije povezane s građevinarstvom, u ovoj je kategoriji bilo dvostruko manje studenata nego u prvoj kategoriji oko $15 \%$. Studiji u području prirodnih znanosti, matematike, statistike te informacijske i komunikacijske tehnologije, koji čine neke od ključnih STEM disciplina, našli su se tek na 
petom mjestu, s udjelom studenata nešto većim od 10\% (Eurostat, 2018). Opći je zaključak međunarodnih izvještaja da se u usporedbi s potrebama suvremenog tržišta rada, premali broj studenata odlučuje za studije u STEM području (National Science Foundation [NSF], 2009). Tome svjedoče ovdje prikazani i inozemni i domaći podaci.

Iako rodna pitanja u STEM području nisu u fokusu ovog rada, valja spomenuti da upravo rodne razlike čine jedan od ključnih problema koji se vežu uz participaciju mladih u visokom obrazovanju i karijerama u STEM području. Naime, žene u odnosu na muškarce značajno rjeđe biraju školovanje i karijere u STEM području (Smith, 2011; OECD, 2012). Ovo je problematičan nalaz s obzirom da takvo stanje pridonosi održavanju rodnih stereotipa u STEM području, ali i problemu nedostatka radne snage u STEM sektorima u brojnim državama svijeta (Aeschlimann, Herzog i Makarovac, 2016).

\section{3. 3. Učeničko sudjelovanje u izvanškolskim aktivnostima u STEM području}

Važna tema u istraživanju učeničkih odabira u STEM području su i učeničke izvanškolske STEM aktivnosti. Naime, u posljednjem se desetljeću učenje sadržaja iz STEM područja uvelike promijenilo s obzirom da su danas, više nego ikad, učenicima dostupni brojni i raznoliki obrazovni izvori izvan okvira formalnog obrazovanja. Takvi izvori, primjerice, uključuju klubove i ljetne škole, interaktivne muzeje i parkove te online materijale o različitim temama iz STEM područja (NRC, 2015). Izvanškolske aktivnosti i iskustva u STEM području mogu se svrstati u različite kategorije. Neki autori razlikuju nestrukturirane aktivnosti, kao što su aktivnosti kod kuće i učenički hobiji u STEM području te aktivnosti koje se odvijaju u strukturiranim uvjetima učenja, kao što su STEM klubovi učenika (Dou, Hazari, Dabney, Sonnert i Sadler, 2019).

DeWitt i Archer (2017) su u istraživanje izvanškolskih aktivnosti u STEM području uključile 6000 učenika u dobi između 11 i 16 godina te su identificirale tri kategorije aktivnosti koje su se razlikovale po nekim važnim obilježjima. Prva kategorija se odnosila na informalna iskustva u STEM području, kao što su posjeti zoološkim vrtovima i akvarijima, provođenje eksperimenata te posjeti znanstvenim centrima i muzejima. Druga kategorija su bile svakodnevne aktivnosti u STEM području kao što je gledanje znanstvenih TV programa, istraživanje tema u STEM području na internetu te razgovaranje o ovim temama s drugim ljudima. Treću kategoriju su činile aktivnosti koje predstavljaju obogaćivanje školskog programa u STEM području. Takve su aktivnosti školski izleti koji su povezani sa STEM sadržajima ili školski posjeti predavanjima i prezentacijama na neku od tema iz STEM 
područja. Pokazalo se da učenici često sudjeluju u svakodnevnim aktivnostima u STEM području, dok je sudjelovanje u strukturiranim informalnim aktivnostima bilo rjeđe. To se može pripisati činjenici da strukturirane aktivnosti u STEM području najčešće iziskuju više planiranja nego svakodnevne aktivnosti te iziskuju potencijalne financijske troškove. Učeničko sudjelovanje u aktivnostima koje predstavljaju obogaćivanje školskog programa u STEM području također je bilo relativno rijetko. Rezultati ovog istraživanja su također ukazali na društvenu nejednakost u participaciji učenika u ovim aktivnostima. Učenici koji pripadaju etničkim manjinama i učenici s nižom razinom kulturalnog kapitala ${ }^{3}$ značajno su rjeđe sudjelovali u informalnim aktivnosti u STEM području od učenika s višom razinom kulturalnog kapitala koji pripadaju ne-manjinskim skupinama (DeWitt i Archer, 2017).

Pri korištenju indikatora koji ukazuju na učeničke odabire u STEM području, istraživači bi trebali uzeti u obzir mogućnosti koje su učenicima dostupne u određenoj etapi obrazovanja, ali i razvojne specifičnosti određene dobi (Simpkins, Davis-Kean i Eccles, 2006). U osnovnoj školi, kada učenici ne mogu birati obrazovno usmjerenje kroz izbor nastavnih predmeta, učenički odabiri u STEM području mogu se operacionalizirati kroz učeničko sudjelovanje u izvanškolskim aktivnostima u ovom području (Simpkins i sur., 2006). S druge strane, kroz period adolescencije, sudjelovanje u izvanškolskim aktivnostima u STEM području sve više opada. Naime, u kasnoj adolescenciji je slobodno vrijeme učenika većinom ispunjeno drugim izvanškolskim aktivnostima, druženjem s vršnjacima te ispunjavanjem redovnih školskih obaveza kod kuće (Larson i Verma, 1999). Stoga je u kasnijim periodima školovanja prikladnije ispitivati obrazovne i profesionalne odabire u užem smislu, kao što je izbor nastavnih predmeta ili izbor područja studiranja u STEM području.

\section{4. Učenička motivacijska uvjerenja u STEM području}

\section{4. 1. Teorija očekivanja i vrijednosti}

Među brojnim teorijama motivacije za postignućem teorija očekivanja i vrijednosti (Eccles, 2005; Eccles i sur., 1983; Eccles i Wigfield, 2002; Wigfied, 1994; Wigfield i Eccles, 2000) ističe se kao jedna od najutjecajnijih teorija, a posebice u okviru istraživanja motivacije

\footnotetext{
${ }^{3}$ Kulturalni kapital je dio šireg sociološkog koncepta kapitala kojeg je predložio Pierre Bourdieu (1986). Koncept kapitala se odnosi na legitimne, vrijedne i razmjenjive resurse koji pridonose stvaranju društvene prednosti u specifičnom području kao što je, primjerice, obrazovanje (Bourdieu, 1986). U spomenutom je radu kulturalni kapital operacionaliziran kao kompozit roditeljskog obrazovanja, frekvencije posjeta muzejima i broja knjiga koje učenik ima kod kuće.
} 
za STEM područje. Ovu su teoriju 1983. godine osmislili američka obrazovna psihologinja Jacquelynne Eccles i njezini suradnici. Osnovni motiv za razvoj teorije bio je vezan upravo uz jedan problem u STEM obrazovnom području. Naime, Eccles i suradnike je zanimalo zašto djevojke značajno rjeđe u odnosu na mladiće biraju zahtjevnije matematičke kolegije, iako u ranijim fazama školovanja postižu sličan uspjeh u matematici kao mladići (Barron i Hulleman, 2015). Zadnjih 30 godina ova teorija je postala široko korištena u svrhu istraživanja i razumijevanja učeničkih odabira, ustrajnosti i postignuća u obrazovanju (Barron i Hulleman, 2015) te se ističe kao dominantno korišten teorijski okvir u istraživanjima diljem svijeta koja se bave konstruktima očekivanja i vrijednosti (Wigfield i Gladstone, 2019).

Kao što sam naziv sugerira, teorija pretpostavlja da su očekivanje uspjeha u nekom zadatku te vrijednost koju pojedinac pridaje uključivanju u taj zadatak ključni za ukupnu motivaciju za bavljenjem tim zadatkom (Wigfield i Cambria, 2010). Primjerice, ako uzmemo u obzir učenički izbor nastavnih predmeta, teorija pretpostavlja da će učenik najvjerojatnije odabrati one predmete za koje smatra da ih može uspješno savladati i koji za njega imaju visoku vrijednost (Eccles, 2005). Teorija se temelji na radovima Kurta Lewina i Edwarda Tolmana koji su prvi definirali konstrukte očekivanja i vrijednosti (Eccles i Wigfield, 2002) te se naslanja na prvi model očekivanja i vrijednosti kojeg je postavio John Atkinson (1957; 1964). Temeljna sličnost između Atkinsonovog modela i suvremene teorije očekivanja i vrijednosti jest što obje teorije pretpostavljaju da su postignuće, ustrajnost i odabir zadataka najizravnije povezani upravo s očekivanjima uspjeha i s vrijednosti zadataka (Wigfield, Tonks i Lutz Klauda, 2009). Ipak, ova se dva modela razlikuju u nekoliko važnih elemenata. Najprije, u suvremenoj teoriji očekivanja i vrijednosti obje su ove motivacijske komponente detaljnije razrađene te su povezane sa širim skupom psiholoških, ali i socijalnih te kulturalnih odrednica. Nadalje, teorijski model Eccles i suradnika pretpostavlja pozitivnu povezanost između konstrukata očekivanja i vrijednosti, dok je Atkinson pretpostavio da su očekivanja i vrijednost zadatka u obrnuto proporcionalnom odnosu (Eccles i Wigfield, 2002). Naposljetku, postavke modela Eccles i suradnika provjeravane su u kontekstu stvarnih situacija vezanih uz postignuće, a ne kroz primjenu laboratorijskih zadataka koji su bili dominantno korišteni u svrhu provjere pretpostavki Atkinsonove teorije (Wigfield i Cambria, 2010).

Barron i Hulleman (2015) u svom pregledu suvremene teorije očekivanja i vrijednosti ističu njezina tri ključna obilježja - riječ je o psihološkom, razvojnom i integrativnom teorijskom modelu. Psihološka dimenzija proizlazi iz važnosti koju ova teorija pridaje subjektivnim uvjerenjima pojedinca, odnosno, očekivanjima i vrijednosti. Pored toga, psihološka dimenzija proizlazi iz pretpostavke da ove dvije vrste uvjerenja nisu utemeljene na 
stvarnim prošlim iskustvima pojedinca, već na osobnim interpretacijama tih iskustava (Eccles i sur., 1983). Razvojna dimenzija teorije proizlazi iz pretpostavke da se motivacijska uvjerenja pojedinca oblikuju tijekom vremena i pod utjecajem različitih individualnih i kontekstualnih faktora. Naposljetku, teorija je integrativna s obzirom da predstavlja sveobuhvatni motivacijski okvir koji objedinjuje različite motivacijske konstrukte koji zajedno u većoj mjeri mogu objasniti učeničke obrazovne odabire, ustrajnost i postignuće nego što to mogu neke druge teorije koje se temelje na izdvojenim motivacijskim konstruktima (Barron i Hulleman, 2015).

Suvremena teorija očekivanja i vrijednosti usmjerena je na dva ključna područja (Wigfield i Gladstone, 2019): (1) prirodu i vremensku promjenu dječjih motivacijskih uvjerenja, vrijednosti i ciljeva vezanih uz različite aktivnosti te kako ova uvjerenja, vrijednosti i ciljevi utječu na dječje postignuće i izbor aktivnosti; te na (2) socijalizacijske prakse kod kuće i u školi koje utječu na razvoj ovih dječjih motivacijskih uvjerenja, vrijednosti i ciljeva. Na Slici 1 je prikazana recentna verzija cjelovitog modela očekivanja i vrijednosti. Kao što je vidljivo, model se sastoji od sekvenci uzročno-posljedičnih veza između različitih skupina konstrukata na razini pojedinca te na razini njegovog kulturalnog i socijalizacijskog okruženja. Krajnji element kojeg model pokušava objasniti su učenički odabiri zadataka i aktivnosti te uspješnost u njima. Ako krenemo s opisom modela s njegove desne strane, vidljivo je da učeničke odabire i postignuće izravno predviđaju učenička očekivanja i vrijednosti vezane uz određeni zadatak ili aktivnost. Ta očekivanja i vrijednosti su pak pod utjecajem niza psiholoških konstrukata. Prvenstveno su pod utjecajem učenikovih uvjerenja vezanih uz zadatak, kao što su uvjerenja o vlastitoj sposobnosti u zadatku, ciljevi te sheme o sebi, ali i pod utjecajem afektivnih sjećanja na prijašnje događaje u kojima se vrednovalo postignuće učenika (Wigfield, Rosenzweig i Eccles, 2017). Nadalje, na ova uvjerenja, ciljeve i afektivna sjećanja djeluju učenikove percepcije stavova i očekivanja drugih ljudi, ali i učenikove interpretacije njegovih prošlih postignuća. Naposljetku, na krajnjoj lijevoj strani modela je vidljivo da su te percepcije i interpretacije učenika pod utjecajem širokog skupa socijalizacijskih i kulturalnih čimbenika te pod utjecajem učenikovih stvarnih sposobnosti i objektivnih prošlih situacija u kojima se vrednovalo njegovo postignuće. Među važnim socijalizacijskim i kulturalnim faktorima ističu se uvjerenja i ponašanja učenikovih roditelja i učitelja te obilježja kulturalnog podneblja u kojem učenik odrasta (Wigfield i sur., 2017). 


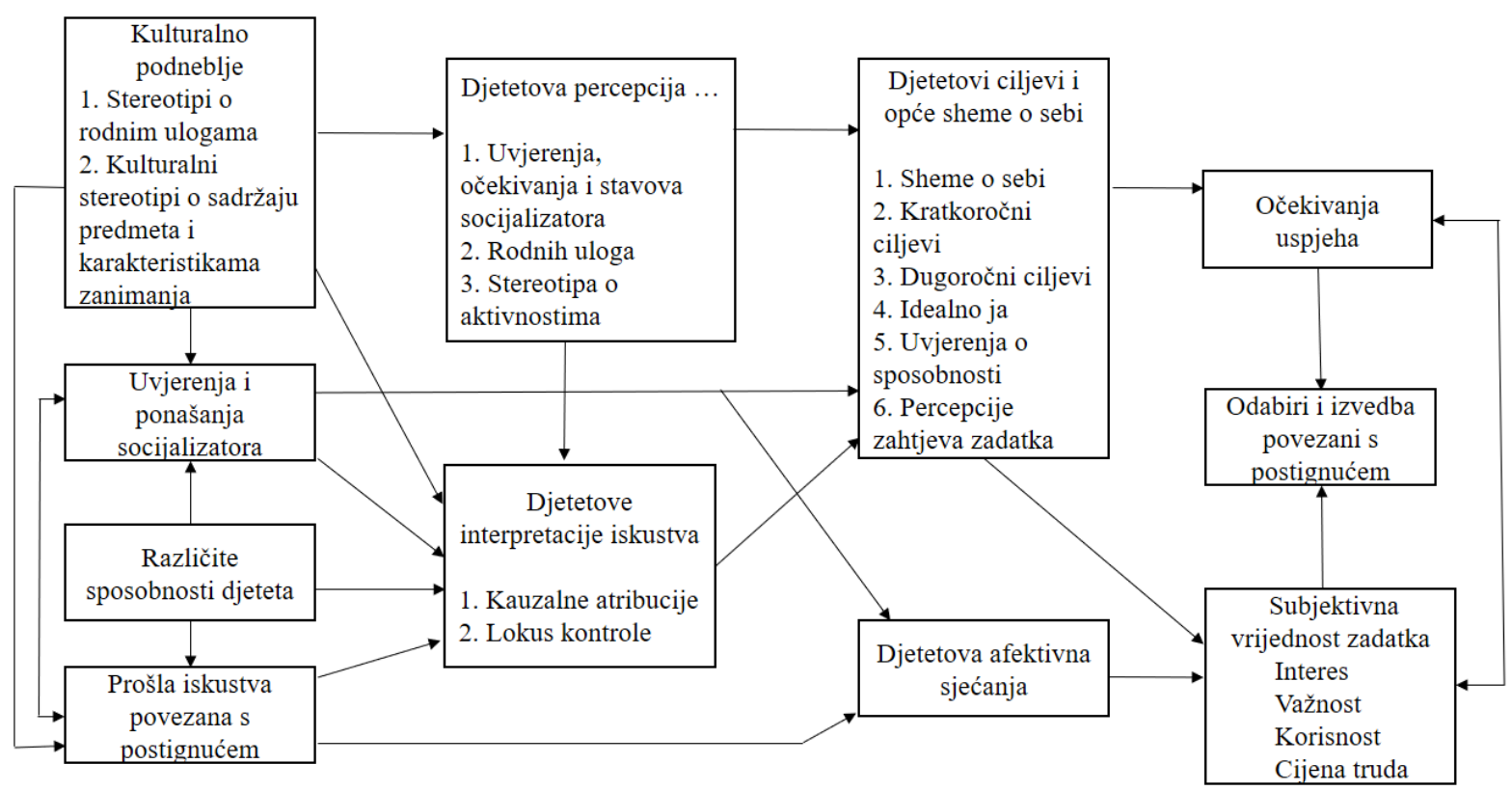

Slika 1. Model očekivanja i vrijednosti Eccles i suradnika (preuzeto iz Wigfield i sur., 2017).

Eccles (2005) ističe četiri obilježja modela koja se ne mogu obuhvatiti ovakvim "statičnim" prikazom. Ta su obilježja ipak važna za razumijevanje individualnih te grupnih razlika u odabirima aktivnosti i zadataka i uspješnosti u njima. Najprije treba napomenuti da se model bavi ponašanjima vezanim uz postignuće koja uključuju ne samo svjesne, već i nesvjesne izbore. Naime, pretpostavka je da se učenički odabiri jednim dijelom temelje na svjesnim aspektima učeničkih motivacijskih uvjerenja. Međutim, model također pretpostavlja da učenici često donose i odluke koje su uvjetovane socijalizacijskim pritiscima i kulturalnim normama kojih učenici nisu uvijek svjesni. Drugi važan aspekt modela, koji nije obuhvaćen njegovim vizualnim prikazom, tiče se šireg područja mogućih odabira pojedinca. Naime, pri donošenju odabira, pojedinci najčešće nisu svjesni ili ne uzimaju u obzir sve mogućnosti koje su im dostupne. Razlozi za to mogu biti neznanje o postojanju određenih opcija ili pak netočne informacije koje pojedinac ima o samoj opciji ili o svojim mogućnostima da tu opciju ostvari. Primjerice, pri odabiru obrazovanja mladi ljudi često nemaju potpune informacije ili imaju netočna saznanja o tome koje aktivnosti određeno područje obrazovanja ili zanimanje uključuje ili pak nemaju dovoljno saznanja o različitim mogućnostima financiranja svog obrazovanja u nekom području (Eccles, 2005). Treće obilježje modela tiče se pretpostavke da učenici donose svoje obrazovne i ostale odabire u vrlo složenom društvenom okruženju u kojem je prisutan čitav niz drugih odabira od kojih svaki ima trenutačne te dugoročne posljedice. Učenici pri donošenju odluka o izboru određenih zadataka ili aktivnosti moraju odvagnuti između različitih pozitivnih i negativnih aspekata svakog odabira. Primjerice, u obrazovnim sustavima u kojima 
učenici odabiru složenost nastavnog programa iz matematike takva se odluka donosi u kontekstu drugih važnih obrazovnih i socijalnih odluka. Zato je često pri donošenju odluka važnija hijerarhija vrijednosti koju učenik veže uz različite dostupne opcije nego apsolutna vrijednost koju veže uz jednu opciju (Eccles, 2005). Naposljetku, iz prikaza modela nije vidljiva pretpostavka da su prikazani procesi razvojni i dinamični. Primjerice, pretpostavlja se da će različita situacijska obilježja, kao i unutarnja stanja pojedinca, utjecati na istaknutost pojedinih komponenti samopoimanja učenika. Sukladno tome, i subjektivna vrijednost različitih opcija može varirati. Pored toga, Eccles (2005) ističe da se psihologijske komponente modela razvojno mijenjaju u funkciji promjena u kognitivnim sposobnostima i interpretacijskim uvjerenjima učenika te promjena u sociokulturalnim utjecajima. Također se očekuje da se i odnosi između varijabli u modelu mijenjaju tijekom vremena (Wigfield i sur., 2017).

S obzirom da ćemo se u ovom radu baviti samo manjim dijelom modela očekivanja i vrijednosti, u daljnjim ćemo se poglavljima usmjeriti na teorijski i empirijski prikaz učeničkih uvjerenja o vlastitim sposobnostima i subjektivnu vrijednost zadataka, s naglaskom na empirijske nalaze u STEM području. Kao što je već rečeno, ova dva skupa varijabli predstavljaju elemente modela za koje se smatra da neposredno predviđaju učeničke obrazovne odabire, ustrajnost i postignuće.

\section{4. 2. Uvjerenja o vlastitim sposobnostima}

Osim što su vrlo važan dio modela očekivanja i vrijednosti, uvjerenja o vlastitim sposobnostima predstavljaju središnji element i brojnih drugih teorija motivacije za postignućem. Među psihologijske konstrukte koji se mogu podvesti pod ovaj širi nadređeni pojam spadaju konstrukti kao što su samopoimanje vlastitih sposobnosti u određenom području, očekivanje uspjeha, samoefikasnost, atribucije i uvjerenja koja osoba ima vezano uz prirodu inteligencije te osjećaj kontrole nad ishodima aktivnosti (Wigfield i sur., 2015; Wigfield, Eccles, Schiefele, Roeser i Davis-Kean, 2006). Bez obzira na specifičnu operacionalizaciju, uvjerenja o vlastitim sposobnostima mogu se najbolje opisati u kontekstu odgovora na pitanje „Mogu li ja obaviti ovaj zadatak?“. Kada je odgovor na ovo pitanje potvrdan, učenici u prosjeku postižu viši obrazovni uspjeh, više se trude, ustrajniji su u zadatku te odabiru one zadatke koji im predstavljaju veći izazov (Wigfield i sur., 2006). 
Među konstruktima koji opisuju učenička uvjerenja o vlastitim sposobnostima, model očekivanja i vrijednosti razlikuje samoefikasnost ${ }^{4}$, percipiranu težinu zadatka te očekivanje uspjeha (Eccles i sur., 2005). Očekivanje uspjeha moguće je definirati kao uvjerenje osobe o tome koliko će biti uspješna u nekom zadatku u bližoj ili daljoj budućnosti (Eccles i sur., 1983). Samoefikasnost se pak odnosi na procjenu pojedinca o njegovoj trenutnoj kompetentnosti u određenom području aktivnosti (Eccles i sur., 1983). Dakle, dok je očekivanje uspjeha orijentirano na budućnost, samoefikasnost predstavlja evaluaciju u sadašnjem trenutku. S obzirom na njihovu konceptualnu sličnost, u ovom je dijelu važno ponuditi nekoliko objašnjenja vezanih uz teorijsku distinkciju između konstrukta samoefikasnosti unutar teorije očekivanja i vrijednosti i socijalno-kognitivne teorije Alberta Bandure (1986). Bandura (1986) samoefikasnost definira kao samoprocjenu vlastitih sposobnosti za organiziranje i izvršavanje akcija koje su potrebne za ostvarenje određenih ishoda. Kao i u modelu očekivanja i vrijednosti, pretpostavlja se da samoefikasnost predviđa osobne izbore pojedinca, postignuće u zadacima, trud i ustrajnost u njima (Bandura, 1986). Procjena samoefikasnosti unutar Bandurinog modela je uvijek vezana uz kontekst koji je u velikoj mjeri specificiran, odnosno, uz procjenu sposobnosti za obavljanje specifičnog zadatka. S druge strane, mjere samoefikasnosti unutar modela očekivanja i vrijednosti su općenitije, odnosno nisu vezane uz toliko visoku razinu specifičnosti. Samoefikasnost unutar modela Eccles i suradnika zapravo odražava osjećaj vlastite vrijednosti koja je povezana s percipiranom kompetencijom (Pajares i Miller, 1994; Pajares i Schunk, 2005). Ovaj se konstrukt odražava u učeničkom odgovoru na pitanje „Jesi li dobar/ra u matematici?“, dok odgovor na pitanje „Možeš li riješiti ovaj matematički problem?“, odražava percepciju samoefikasnosti unutar Bandurine teorije (Pajares i Miller, 1994). Nedavno istraživanje u području prirodoslovlja pokazalo je da su ove dvije mjere visoko povezani, ali odvojivi konstrukti (Jansen, Scherer i Schroeders, 2015). Nalazi na koje ćemo se referirati u ostatku ovog rada odnose se na istraživanja koja su se bavila konstruktom samoefikasnosti unutar modela očekivanja i vrijednosti.

Empirijska istraživanja učeničkih uvjerenja o vlastitim sposobnostima trebaju u obzir uzeti njihovu područnu specifičnost. Naime, već u prvom razredu osnovne škole, kada je

\footnotetext{
${ }^{4}$ Originalni naziv ovog konstrukta na engleskom jeziku se razlikuje u pojedinim istraživanjima pa se tako spominju termini "self-concept of ability" (npr. Wigfield i sur., 2015), "ability self-concept" (npr. Eccles, O’Neill i Wigfield, 2005) i "self-perception of ability" (npr. Bleeker i Jacobs, 2004). U domaćim su radovima također korišteni različiti prijevodi ovog konstrukta, kao što je "uvjerenja o sposobnosti" (Rovan, Pavlin-Bernardić i Vlahović-Štetić, 2013) te "samopoimanje vlastitih sposobnosti" (Jugović, Baranović i Marušić, 2012). U ovom ćemo radu koristiti prijevod samoefikasnost. Međutim, treba imati na umu razlike između ovog konstrukta unutar modela očekivanja i vrijednosti i Bandurinog (1986) konstrukta samoefikasnosti, što je detaljnije objašnjeno u nastavku ovog poglavlja.
} 
iskustvo sa školskim i izvanškolskim aktivnostima još relativno ograničeno, djeca pokazuju različitu samoefikasnost u različitim područjima aktivnosti kao što su matematika, čitanje, sport i glazba (Eccles, Wigfield, Harold i Blumenfeld, 1993). Primjerice, iako učeničko postignuće u matematici i jezičnim predmetima značajno korelira, učenička samoefikasnost u ovim predmetima je gotovo nepovezana (Marsh, 1990). Razlikovnost u učeničkoj samoefikasnosti je potvrđena i unutar STEM područja. Primjerice, pokazalo se da srednjoškolci čine razliku u percepciji svoje samoefikasnosti u biologiji, kemiji i fizici (Simpkins i sur., 2015b).

\section{4. 3. Subjektivna vrijednost zadataka}

Prema modelu očekivanja i vrijednosti, subjektivna vrijednost zadatka ima četiri komponente koje su povezani, ali empirijski odvojivi konstrukti. Važnost se može definirati kao osobno značenje koje pojedinac pridaje uspješnom bavljenju aktivnošću, odnosno, kao osjećaj povezanosti uspjeha u zadatku s osobnim identitetom (Eccles i Wigfield, 2002). U kontekstu STEM obrazovanog područja, ova komponenta može se operacionalizirati kao važnost koju učenik pridaje postizanju visokog uspjeha u nastavnim predmetima STEM područja. Važnost ukazuje u kojoj mjeri određeni zadatak doprinosi zadovoljavanju osobnih potreba učenika te iskazivanju osobnog i socijalnog identiteta učenika. Pokazalo se da važnost ima istaknutiju ulogu u uključenosti u određeno područje kod starijih učenika, a moguće je da je razlog tome činjenica da je kod starijih učenika osjećaj identiteta snažnije formiran (Eccles i Wang, 2012). Interes ili intrinzična vrijednost definira se kao uživanje u bavljenju aktivnošću (Eccles i Wigfield, 2002) ili kao anticipirano uživanje kojeg osoba očekuje u situaciji bavljenja nekim zadatkom (Eccles, 2005). Korisnost je komponenta vrijednosti koja opisuje u kojoj je mjeri domena postignuća povezana sa sadašnjim ili budućim ciljevima osobe. Iako predstavlja empirijski odvojivu vrijednosnu komponentu, percepcija korisnosti može pozitivno djelovati i na intrinzičnu vrijednost zadatka budući da se direktno odnosi na internalizirane kratkoročne i dugoročne ciljeve osobe (Eccles i Wigfield, 2002). S obzirom da mjere korisnosti mogu ukazivati na osobne ciljeve koji su internalizirani, ova vrijednosna komponenta može biti iskaz pojma o sebi, kao što je to komponenta važnosti (Eccles, 2005). Čestice koje mjere korisnost i važnost se u empirijskim istraživanjima često kombiniraju u jednu mjeru (npr. Durik, Vida i Eccles, 2006; Jacobs, Lanza, Osgood, Eccles i Wigfield, 2002; Simpkins i sur., 2012; Viljaranta, Lazarides, Aunola, Räikkönen i Nurmi, 2015; Watt i sur., 2012). Naposljetku, cijena truda je komponenta subjektivne vrijednosti zadatka koja je pod utjecajem faktora kao što su anksioznost i strah od neuspjeha, strah od socijalnih posljedica uspjeha u aktivnosti (npr. 
odbacivanje od strane vršnjaka), strah od gubitka osjećaja vlastite vrijednosti ili percepcija gubitka vremena i energije za bavljenje drugim aktivnostima. Ova komponenta odnosi se na percepciju pojedinca od čega mora odustati, a koliko treba uložiti da bi se bavio pojedinom aktivnošću (Eccles, 2005).

Komponente subjektivne vrijednosti zadatka pojavljuju se u obliku različitih operacionalizacija i u drugim motivacijskim teorijama, a posebice se tu ističe komponenta intrinzične vrijednosti zadatka te komponenta korisnosti. Intrinzična vrijednost zadatka slična je konstruktu intrinzične motivacije iz teorije samoodređenja Decija i Ryana (1985). Unutar ove teorije, intrinzična motivacija se odnosi na proaktivnu, cilju orijentiranu ljudsku prirodu koja čini osnovu za čovjekovo učenje i razvoj (Vansteenkiste, Lens i Deci, 2006). Intrinzična motivacija ima karakteristiku autonomije budući da uključuje iskustvo odlučivanja i odabira, za razliku od kontroliranih oblika motivacije kojim je u osnovi iskustvo pritiska ili osjećaja primoranosti (Vansteenkiste i sur, 2006). Intrinzična vrijednost zadatka se također može povezati s konstruktom interesa (Renninger, Hidi i Krapp, 1992; Tobias, 1994), pri čemu većina istraživača razdvaja koncept individualnog i situacijskog interesa. Individualni interes se definira kao relativno stabilna vrijednosna orijentacija prema određenim područjima aktivnosti, dok je situacijski interes tip afektivnog stanja kojeg pobuđuju određene karakteristike zadatka kojim se osoba bavi, kao što su osobna važnost, novost, razina aktivnosti ili razumljivost (Eccles i Wigfield, 2002). S obzirom da se intrinzična vrijednost zadataka odnosi na pozitivne osjećaje koja osoba doživljava prilikom uključenosti u zadatak, ova komponenta vrijednosti se može povezati sa situacijskim interesom (Lazarides, Harackiewicz, Pesu i Viljaranta, 2015). Komponenta korisnosti može se povezati s ekstrinzičnom motivacijom definiranom u okviru teorije samoodređenja. Međutim, kao što smo ranije naveli, korisnost može imati i intrinzični aspekt $\mathrm{s}$ obzirom da može ukazivati na potencijal sudjelovanja u aktivnosti za ostvarivanje osobno smislenih i važnih ciljeva (Hulleman, Godes, Hendricks i Harackiewicz, 2010).

\section{4. 4. Razlikovnost učeničkih motivacijskih uvjerenja}

Pretpostavka originalnog modela očekivanja i vrijednosti je da samoefikasnost $u$ interakciji s percipiranom težinom zadatka predviđa očekivanje uspjeha u konkretnom području (Eccles i sur., 2005). Pretpostavlja se da je samoefikasnost pozitivno, a percipirana težina zadatka negativno povezana s očekivanjem uspjeha (Eccles i sur., 2005). Međutim, u empirijskim provjerama modela je utvrđeno da su samoefikasnost i očekivanje uspjeha zasićeni istim faktorom te se zato u istraživanjima mogu tretirati kao isti konstrukt (Eccles, 2009; Eccles 
i Wigfield, 1995). Zato se u novije vrijeme u brojnim istraživanjima mjera samoefikasnosti koristi kao mjera očekivanja uspjeha u određenom obrazovnom području (npr. Musu-Gillette, Wigfield, Harring i Eccles, 2015; Simpkins i sur., 2012; Wang i sur., 2013).

Istraživanja pokazuju da mlađa djeca, u dobi između sedam i deset godina ne razlikuju pojedine komponente subjektivne vrijednosti zadatka, već one čine jedan zajednički faktor (Eccles i sur., 1993b). Istraživanja u području matematike koja su obuhvatila učenike u periodu adolescencije pokazala su da su opisane komponentne subjektivne vrijednosti zadatka empirijski razdvojive (Conley, 2012; Eccles i Wigfield, 1995; Trautwein i sur., 2012).

Diferencijacija između uvjerenja o vlastitim sposobnostima i subjektivne vrijednosti zadatka koja je pretpostavljena modelom očekivanja i vrijednosti potvrđena je već kod učenika u dobi od sedam godina (Eccles i sur., 1993b). Iako je riječ o razdvojivim konstruktima, akademska samoefikasnost i subjektivna vrijednost zadatka su pozitivno povezani te se najčešće radi o umjerenim do snažnim korelacijama (Wigfield i Eccles, 2002; Wigfield i sur., 2009). U longitudinalnom istraživanju Jacobs i suradnika (2002) promjena u učeničkom uvjerenju o vlastitoj sposobnosti u matematici tijekom školovanja pozitivno je predviđala promjenu u subjektivnoj vrijednosti matematike. Također se pokazalo da je samoefikasnost od svih komponenti subjektivne vrijednosti zadatka najviše povezana s interesom (Wigfield i sur., 2009).

Model očekivanja i vrijednosti pretpostavlja da samoefikasnost u određenom području utječe na razvoj subjektivne vrijednosti zadatka u tom području (Eccles i Wigfield, 2002). Mac Iver, Stipek i Daniels (1991) su dobili podršku za ovaj smjer utjecaja na uzorku srednjoškolaca u dva nastavna predmeta STEM područja - matematici i prirodoslovlju. Promjena u učeničkoj akademskoj samoefikasnosti tijekom jednog akademskog polugodišta predviđala je promjenu u vrijednosti koju učenici pridaju ovim nastavnim predmetima te je taj smjer utjecaja bio snažniji nego obrnuti smjer utjecaja između ova dva konstrukta. U nedavnom je istraživanju niska učenička samoefikasnost u matematici u dobi od oko deset godina predviđala snažniji pad u učeničkom interesu za matematiku kroz tri točke mjerenja (Denner, Valdes, Dickson i Laursen, 2019). Nalazi o smjeru utjecaja između samoefikasnosti i vrijednosti zadatka impliciraju da povećanje učeničke percepcije vlastite sposobnosti u obrazovnom području dovodi i do toga da učenici sadržaj kojeg uče vide zanimljivijim i korisnijim (Mac Iver i sur., 1991). Opisani smjer utjecaja između ova dva konstrukta moguće je objasniti različitim procesima. Smatra se da tijekom vremena djeca počinju pridavati više vrijednosti područjima aktivnosti u kojima su kompetentna zbog procesa povezanih s klasičnim uvjetovanjem pozitivan učinak iskustva kompetentnosti u određenoj aktivnosti počinje se povezivati sa 
samom aktivnosti (Eccles i sur., 1983). Pored toga, smanjivanje vrijednosti koju dijete pridaje aktivnostima koje su mu teške i u kojima se ne percipira kompetentnim može služiti kao mehanizam zaštite samopoštovanja i općeg osjećaja samoefikasnosti (Eccles, Wigfield i Schiefele, 1998).

\section{4. 5. Dobne i rodne razlike u učeničkim motivacijskim uvjerenjima u STEM području}

Prethodna su istraživanja pronašla određene dobne $\mathrm{i}$ rodne razlike $\mathrm{u}$ dječjim motivacijskim uvjerenjimau. Eccles i suradnici (1993b) su utvrdili da u nižim razredima osnovne škole mlađa djeca pozitivnije vrednuju svoje sposobnosti u različitim STEM i neSTEM područjima od starije djece. Longitudinalna istraživanja također su potvrdila pad učeničke samoefikasnosti u matematici tijekom perioda osnovne i srednje škole (Jacobs i sur., 2002; Pesu, Aunola, Viljaranta, Hirvonen i Kiuru, 2018). U pogledu rodnih razlika, istraživanja pokazuju da dječaci u odnosu na djevojčice pozitivnije procjenjuju svoje sposobnosti u STEM područjima kao što su matematika i prirodoslovlje (Arens i sur., 2017; Eccles i sur., 1993b; Guo, Parker, Marsh i Morin, 2015; Heller i Ziegler, 1996; Jacobs i sur., 2002; Juang i Silbereisen, 2002; Lauermann, Tsai i Eccles, 2017; Pajares, 1996) te u sportu (Eccles i sur., 1993b; Jacobs i sur., 2002), dok djevojčice pozitivnije vrednuju svoje sposobnosti u čitanju, glazbi i jezicima (Eccles i sur., 1993b; Jacobs i sur., 2002). Ove razlike slijede rodno-stereotipna kulturalna uvjerenja o rodnim razlikama u pojedinim područjima aktivnosti (Eccles i sur., 1993b). Međutim, većina pronađenih rodnih razlika u uvjerenjima o vlastitim sposobnostima u različitim područjima aktivnosti su relativno male (Wigfield i sur., 2015). Kada govorimo isključivo o STEM području, treba reći da očekivane rodne razlike nisu pronađene u svim istraživanjima. Primjerice, Simpkins i suradnice (2006) su utvrdile značajne rodne razlike u samoefikasnosti u matematici u korist dječaka, no isti nalaz nije potvrđen u području prirodoslovlja. Pored toga, u longitudinalnom istraživanju Jacobs i suradnika (2002) se pokazalo da je stopa opadanja percepcije vlastite kompetentnosti u matematici tijekom vremena bila izraženija kod učenika nego kod učenica. Stoga su do početka srednje škole djevojke i mladići pokazivali slična uvjerenja o svojoj sposobnosti u matematici.

U pogledu dobnih razlika u subjektivnoj vrijednosti zadatka, u prethodno spomenutom longitudinalnom istraživanju Jacobs i suradnika (2002), koje je obuhvatilo razvojni period čitave osnovne i srednje škole, pokazalo se da subjektivna vrijednost koju učenici pridaju matematici, jeziku i sportu opada tijekom osnovnog i srednjeg školovanja. Dok je u području jezika pad subjektivne vrijednosti tijekom vremena usporio, u području matematike on je čak 
pokazao lagano ubrzanje. Također, prosječni pad vrijednosti je za jezike bio najveći tijekom osnovne škole, a za matematiku tijekom srednje škole (Jacobs i sur., 2002). Kada govorimo o rodnim razlikama, Eccles i suradnici (1993b) su kod učenika u nižim razredima osnovne škole pronašli isti obrazac rodnih razlika u subjektivnoj vrijednosti zadatka za različita područja aktivnosti kakav su pronašli i za njihova uvjerenja o vlastitim sposobnostima. Tako se pokazalo da u nižim razredima osnovne škole dječaci u odnosu na djevojčice pozitivnije vrednuju matematiku i sport, dok djevojčice u odnosu na dječake pozitivnije vrednuju čitanje i glazbene aktivnosti. Međutim, ovaj nalaz nije potvrđen u svim istraživanjima. Jacobs i suradnici (2002) nisu pronašli razliku u prosječnom vrednovanju matematike kod djevojčica i dječaka tijekom perioda osnovne i srednje škole. Simpkins i suradnice (2006) nisu pronašle rodne razlike u učeničkom vrednovanju matematike i prirodoslovlja tijekom viših razreda osnovne te nižih razreda srednje škole. Novija istraživanja sugeriraju da nema rodnih razlika u učeničkom vrednovanju matematike, no da dječaci za razliku od djevojčica i dalje više vrednuju područje fizike, računalnih znanosti i inženjerstva (Eccles, 2013; Wang, Eccles i Kenny, 2013).

\section{5. Odnos između učeničkih motivacijskih uvjerenja, obrazovnih odabira i postignuća}

\section{5. 1. Motivacijska uvjerenja kao prediktori obrazovnih ishoda}

U velikom broju dosadašnjih istraživanja učenička uvjerenja o sposobnosti i subjektivna vrijednost zadatka u različitim STEM disciplinama, kao što su matematika, prirodoslovlje i računarstvo, potvrđena su kao značajni prediktori niza obrazovnih i profesionalnih ishoda vezanih uz ova područja. Među tim ishodima su obrazovne i profesionalne aspiracije učenika u STEM području (npr. DeWitt i sur., 2013; Jansen i sur., 2015), trud kojeg učenici ulažu u nastavne predmete STEM područja (npr. Chouinard, Karsenti i Roy, 2007), postignuće u ovim predmetima (npr. Nagengast i sur., 2011; Meece, Wigfield i Eccles, 1990; Trautwein i sur., 2012), namjera izbora te izbor nastavnih predmeta STEM područja u srednjoj školi (npr. Dickhäuser i Stiensmeier-Pelster, 2003; Guo i sur.,2015; Meece i sur., 1990; Simpkins i sur., 2006), izbor STEM područja studiranja (npr. Guo i sur., 2015; Musu-Gillette i sur., 2015) te procijenjena samoefikasnost u karijerama u STEM području (npr. Bleeker i Jacobs, 2004).

Međutim, neka istraživanja sugeriraju da kada se $u$ istom istraživanju u obzir uzmu i uvjerenja o sposobnosti i subjektivna vrijednost zadatka ove dvije vrste motivacijskih uvjerenja imaju različiti doprinos u objašnjavanju učeničkih obrazovnih ishoda, posebice obrazovnog postignuća i obrazovnih odabira. Tako se pokazalo da je učenička samoefikasnost snažnije 
povezana s kasnijim obrazovnim postignućem, dok je subjektivna vrijednost zadatka snažnije povezana s obrazovnim planovima i konačnim obrazovnim odabirima (Eccles i sur., 2005). U istraživanju koje su proveli Eccles, Adler i Meece (1984) na uzorku učenika u dobi između 14 i 16 godina, samo je učenička samoefikasnost u matematici bila povezana s kasnijim učeničkim ocjenama iz matematike. $U$ istom se istraživanju subjektivna vrijednost matematike pokazala kao najsnažniji prediktor učeničkih obrazovnih planova o upisu nastavnih predmeta iz područja matematike.

$\mathrm{U}$ recentnom istraživanju $\mathrm{u}$ području matematike dobivena je slična razlika $u$ prediktorskoj ulozi ova dva motivacijska konstrukta (Guo i sur., 2016). U dobi od oko 15 godina, učenička samoefikasnost u matematici snažnije je predviđala učeničko postignuće u matematici nego učenička subjektivna vrijednost matematike. S druge strane, učenička subjektivna vrijednost matematike pokazala se snažnijim prediktorom samoprocjene učeničkog truda u matematici. Zanimljiv je nalaz da su ove dvije vrste motivacijskih uvjerenja bile jednako važni prediktori učiteljske procjene učeničke uključenosti u matematiku (Guo i sur., 2016).

Treba ipak napomenuti da opisane razlike između subjektivne vrijednosti zadatka i uvjerenja o vlastitim sposobnostima nisu potvrđene u svim istraživanjima (Eccles i sur., 2005). Primjerice, u longitudinalnom istraživanju Simpkins i suradnica (2006) učenička samoefikasnost u matematici i prirodoslovlju u osnovnoj školi je snažnije predviđala broj nastavnih predmeta STEM područja koje je učenik odabrao slušati u srednjoj školi nego subjektivna vrijednost matematike i prirodoslovlja u osnovnoj školi. Autorice ovaj nalaz pripisuju povijesnim promjenama u kriterijima za upis na fakultet. Naime, u 21. stoljeću je broj učenika koji se prijavljuju za upis na fakultete značajno porastao, zbog čega su uvjeti za upis fakulteta, u pogledu učeničkog akademskog postignuća i naprednih obrazovnih aktivnosti sve stroži. S obzirom da većina mladih želi upisati fakultet, većina ih je vjerojatno i svjesna vrijednosti koje STEM obrazovni sadržaji imaju za njihove buduće obrazovanje i karijeru. Učenička samoefikasnost u predmetima STEM područja tako može igrati važniju ulogu u učeničkim odabirima zbog uske povezanosti ovog konstrukta sa školskim ocjenama učenika. Moguće je da učenici koji imaju pozitivnije viđenje vlastitih sposobnosti u nastavnim predmetima STEM područja u srednjoj školi odabiru veći broj STEM sadržaja jer očekuju da će i u budućnosti ostvariti visoke ocjene u ovim predmetima (Simpkins i sur., 2006).

Jedna od vrlo slabo istražnih pretpostavki modela očekivanja i vrijednosti tiče se pretpostavke o postojanju interakcije između samoefikasnosti i subjektivne vrijednosti zadataka u predviđanju obrazovnih ishoda učenika (Guo i sur., 2016). Istraživanje kojeg su proveli Guo i suradnici (2016) u području matematike potvrdilo je da u predviđanju učeničkih obrazovnih 
ishoda u matematici postoji tzv. sinergijska interakcija između ova dva motivacijska uvjerenja, koja je i pretpostavljena suvremenim modelom očekivanja i vrijednosti. Pobliže, to znači da učenici postižu više obrazovne rezultate u matematici, pokazuju viši trud i visoko su uključeni u nastavu iz matematike jedino kada su i samoefikasnost u matematici i vrijednost koju učenici pridaju matematici relativno visoki ${ }^{5}$ (Guo i sur., 2016). Kada su dodatno provjerene interakcije između samoefikasnosti i zasebnih komponenti subjektivne vrijednosti zadatka, dobivena je sinergijska interakcija između visoke samoefikasnosti i niske cijene truda u predviđanju matematičkog postignuća. To znači da je manje vjerojatno da će učenici koji visoko percipiraju svoju sposobnost u matematici postizati visoke rezultate u matematici ukoliko istovremeno percipiraju da ulaganje truda u matematiku iziskuje mnogo vremena i energije (Guo i sur., 2016).

Model očekivanja i vrijednosti također pretpostavlja da različite komponente subjektivne vrijednosti zadatka imaju različit doprinos u predviđanju učeničkih obrazovnih ishoda (Eccles, 2009). Međutim, istraživanja u kojima je simultano provjeren doprinos različitih vrijednosnih komponenti u objašnjavanju učeničkog postignuća, odabira aktivnosti ili obrazovnih i profesionalnih aspiracija, uz istovremenu kontrolu učeničkog uvjerenja o vlastitim sposobnostima, su vrlo rijetka (Guo i sur., 2016). Dio razloga za to je visoka kolinearnost između komponenti subjektivne vrijednosti zadatka koja predstavlja prepreku za uključivanje više komponenti vrijednosti kao prediktora u isti model (Guo i sur., 2016). U jednom od rijetkih istraživanja u kojem je ispitan doprinos više od jedne komponente subjektivne vrijednosti, pokazalo se da je, uz kontrolu učeničke samoefikasnosti u matematici, kompozitna mjera važnosti i korisnosti matematike snažnije predviđala obrazovne aspiracije srednjoškolaca nego intrinzična vrijednost matematike. S druge strane, intrinzična vrijednost matematike snažnije je predviđala učeničko polaženje nastavnih predmeta u području matematike u srednjoj školi (Watt i sur., 2012). U nedavnom su istraživanju Guo i suradnici (2016) problem kolinearnosti komponenata subjektivne vrijednosti zadatka razriješili formiranjem latentnog dvo-faktorskog modela kojim se u obzir mogla uzeti multidimenzionalna priroda subjektivne vrijednosti zadatka i preklapanje između pojedinih komponenti vrijednosti. Od svih komponenti subjektivne vrijednosti zadatka jedino je percipirana niska cijena truda bila povezana s višim učeničkim postignućem u matematici. Također se pokazalo da važnost ima važniju ulogu u

\footnotetext{
${ }^{5} \mathrm{Za}$ razliku od sinergijske interakcije, potvrda tzv. kompenzatorne interakcije značila bi da su učenici visoko motivirani za uključivanje u određeni zadatak dok god pokazuju ili visoku samoefikasnost u području ili visoko vrednovanje područja. U novijim istraživanjima nije dobivena podrška za kompenzatornu interakciju između samoefikasnosti i subjektivne vrijednosti zadatka u STEM i ne-STEM akademskim područjima (Guo i sur., 2016; Nagengast i sur., 2011; Trautwein i sur., 2012).
} 
predviđanju učeničkog truda u matematici, čak i uz kontrolu opće subjektivne vrijednosti zadatka. S druge strane, percipirana korisnost matematike nije imala nezavisni doprinos u predviđanju učeničkog postignuća, truda ili uključenosti u matematiku, što se možda može prepisati tome što je percipirana korisnost važnija za učeničke obrazovne odabire te obrazovne i profesionalne aspiracije (Guo i sur., 2016). Rezultati ovog istraživanja daju podršku konceptualnom razlikovanju komponenti subjektivne vrijednosti zadatka (Guo i sur., 2016).

\section{5. 2. Recipročni utjecaji u modelu očekivanja i vrijednosti}

Za mnoge odnose u modelu očekivanja i vrijednosti pretpostavljen je recipročan smjer utjecaja. Tako se pretpostavlja da obrazovni odabiri učenika utječu na učenička kasnija motivacijska uvjerenja, a ta uvjerenja pak utječu na kasnije odabire učenika (Eccles, 1994). Simpkins i suradnice (2006) su prve provjerile ove pretpostavke kroz longitudinalno istraživanje u dva nastavna predmeta STEM područja - matematici i prirodoslovlju. Pritom su koristile dvije mjere učeničkih odabira aktivnosti. U petom razredu osnovne škole, kada učenici u SAD-u još ne mogu birati složenost obrazovnih sadržaja, autorice su učeničke odabire operacionalizirale kao čestinu učeničkog sudjelovanja u izvanškolskim aktivnostima povezanim s matematikom i prirodoslovljem. Tijekom srednje škole je kao mjera učeničkih odabira korišten podatak o tome koliko je matematičkih i prirodoslovnih nastavnih predmeta učenik slušao tijekom svog srednjoškolskog obrazovanja. Rezultati istraživanja pokazali su da je odabir izvanškolskih aktivnosti u petom razredu osnovne škole predviđao učeničku kasniju samoefikasnost i subjektivnu vrijednost u području matematike i prirodoslovlja. Također, kao što je bilo i očekivano, subjektivna vrijednost zadatka i samoefikasnost u matematici i prirodoslovlju u osnovnoj školi pozitivno su predviđali kasnije obrazovne odabire u matematici i prirodoslovlju u adolescenciji.

Teorija također pretpostavlja da učenička motivacijska uvjerenja predviđaju kasnije postignuće, ali i da ranije postignuće, koje učenicima služi kao važan oblik povratne informacije o njihovoj akademskoj izvedbi, predviđa kasnija motivacijska uvjerenja i odabire učenika (Eccles i sur., 1984). Simpkins i suradnice (2006) su empirijski provjerile ulogu učeničkog postignuća kao prediktora motivacijskih uvjerenja i obrazovnih odabira u matematici $\mathrm{i}$ prirodoslovlju. Pokazalo se da je veća vjerojatnost da će učenici odabirati izvanškolske i nastavne sadržaje vezane uz matematiku i prirodoslovlje u osnovnoj i srednjoj školi ukoliko su prethodno ostvarili bolje ocjene iz matematike i prirodoslovlja. Također, učeničke ocjene iz matematike i prirodoslovlja u petom razredu osnovne škole predviđale su učeničku 
samoefikasnost u matematici i prirodoslovlju te učenički interes za ove predmete godinu dana kasnije. Međutim, isti nalaz nije potvrđen za važnost koju učenici pridaju ovim predmetima, što je u skladu s ranijim nalazom Ecless (1994) prema kojem su samoefikasnost i interes u većoj mjeri pod utjecajem školskih ocjena nego važnost koju učenici pridaju obrazovnom području. Do sad najrobusniju potvrdu recipročnih odnosa između samoefikasnosti u matematici i matematičkog postignuća dalo je nedavno istraživanje u kojem su isti učenici praćeni u periodu između 12. i 17. godine (Arens i sur., 2017). U tzv. križnom modelu koji je u istraživanju testiran, putevi od samoefikasnosti do postignuća i od postignuća do samoefikasnosti bili su slični veličinom te stabilni kroz pet valova istraživanja. Osim toga, ovi nalazi potvrđeni su i uz kontrolu različitih relevantnih kovarijati kod učenika u različitim vrstama srednjih škola te kada su korišteni različiti indikatori matematičkog postignuća (Arens i sur., 2017).

Na kraju ovog dijela uvoda važno je definirati što u ovom istraživanju podrazumijevamo pod pojmom ,učenički obrazovni ishodi“. Iz pozicije teorije očekivanja i vrijednosti (Eccles i sur., 1983; Eccles, 2005; Eccles i Wigfield, 2002; Wigfield i Eccles, 2002), koja predstavlja preuzeti teorijski okvir u ovom istraživanju, pod ovim se pojmom prvenstveno podrazumijevaju učenički odabiri nastavnih predmeta, područja obrazovanja ili izvannastavnih aktivnosti; zatim učenička ustrajnost $\mathrm{u}$ odabranim aktivnostima ili obrazovanju te učeničko postignuće $\mathrm{u}$ obrazovnom području. Međutim, osim ovih konstrukata koji se odnose na ponašajne ishode, važnu ulogu u STEM obrazovnom području ima i učenička motivacija. Američko Nacionalno istraživačko vijeće u svom izvješću iz 2011. godine naglašava da je osim postignuća učenika i postignuća škola u testovima znanja, pri procjeni obrazovnih ishoda u STEM području nužno u obzir uzeti i konstrukte kao što su motivacija i interes učenika za STEM sadržaje. Vijeće također napominje da je potrebno češće u empirijska istraživanja uključivati ovaj oblik učeničkih ishoda (NRC, 2011). Stoga u ovom radu pod pojmom „učenički obrazovni ishodi u matematici i tehničkoj kulturi“ podrazumijevamo učeničko postignuće i odabir aktivnosti, ali i motivacijska uvjerenja u ovim predmetima.

\section{6. Roditeljski utjecaji u STEM području}

1. 6. 1. Model roditeljske socijalizacije dječjih obrazovnih ishoda

Roditeljski utjecaji objašnjavaju učeničke razlike u čitavom nizu ishoda u STEM obrazovnom području, među kojima su školsko postignuće (Acosta i Hsu, 2014; Berkowitz i sur., 2015; Ing, 2014), uvjerenja o vlastitim sposobnostima (Bhanot i Jovanovic, 2009; 
Simpkins i sur., 2012; Simpkins, Fredricks, i Eccles, 2015b), stavovi, interes i vrijednosti (Breakwell i Beardsell, 1992; Jacobs i Bleeker, 2004; Simpkins i sur., 2012; Simpkins, Fredricks, i Eccles, 2015a), odabir nastavnih predmeta (Harackiewicz, Rozek, Hulleman i Hyde, 2012) te odabir izvannastavnih aktivnosti (Breakwell i Beardsell, 1992; Jacobs i Bleeker, 2004; Simpkins, Davis-Kean i Eccles, 2005). Koristan teorijski okvir za istraživanje i razumijevanje ovih odnosa jest model roditeljske socijalizacije dječjih obrazovnih ishoda ${ }^{6}$ (Eccles, 1993; 2007). Ovaj model je uklopljen unutar modela očekivanja i vrijednosti Eccles i suradnika te detaljnije opisuje kako obitelj, a posebice roditelji, oblikuju dječje odabire i postignuće, primarno kroz utjecaj na dječja motivacijska uvjerenja (Simpkins i sur., 2015a).

Kao što je vidljivo iz Slike 2, model pretpostavlja nekoliko skupina roditeljskih utjecaja te niz izravnih, neizravnih te moderatorskih odnosa između ovih skupina varijabli (Eccles, 1993; Simpkins i sur. 2015a). Kao najdalji (distalni) mehanizmi roditeljskih utjecaja postavljene su roditeljske i obiteljske sociodemografske karakteristike, kao što su obrazovanje roditelja, financijski status obitelji, zanimanje i rod roditelja. Sljedeća skupina konstrukata su opća roditeljska uvjerenja i ponašanja, kao što su roditeljski rodni stereotipi, uvjerenja o efikasnosti, roditeljske opće i specifične vrijednosti te odgojni stilovi. Nadalje, istaknutu ulogu u modelu imaju roditeljska uvjerenja specifična za dijete, kao što su roditeljska očekivanja vezana uz djetetovo postignuće, percepcija djetetovih sposobnosti i interesa te percepcija vrijednosti određenih vještina za dijete. Naposljetku se u modelu navode različita roditeljska ponašanja. To su primjerice roditeljsko modeliranje te različita roditeljska ponašanja specifična za područja aktivnosti, među kojima su poticanje djetetovih aktivnosti i interesa, zajednička uključenost roditelja s djetetom $\mathrm{u}$ aktivnosti te roditeljsko pribavljanje materijala $\mathrm{i}$ iskustava za dijete (Simpkins i sur., 2012).

\footnotetext{
${ }^{6}$ Originalni naziv modela u radovima Eccles i suradnika glasi "parent socialization model "(npr. Eccles, 2005) ili samo "socialization model" (npr. Fredricks, Simpkins i Eccles, 2005). U kasnijim radovima (npr. Eccles, 2007; Simpkins i sur., 2015a) pojavljuje se i dulji naziv - "model of parents' influence on children's achievement related to self-perception, values, and behaviors". U ovom ćemo se radu pri referiranju na model služiti prijevodom "model roditeljske socijalizacije dječjih obrazovnih ishoda", pri čemu se "dječji obrazovni ishodi" odnose na dječja motivacijska uvjerenja, ponašanja, tj. odabire aktivnosti i školsko postignuće.
} 


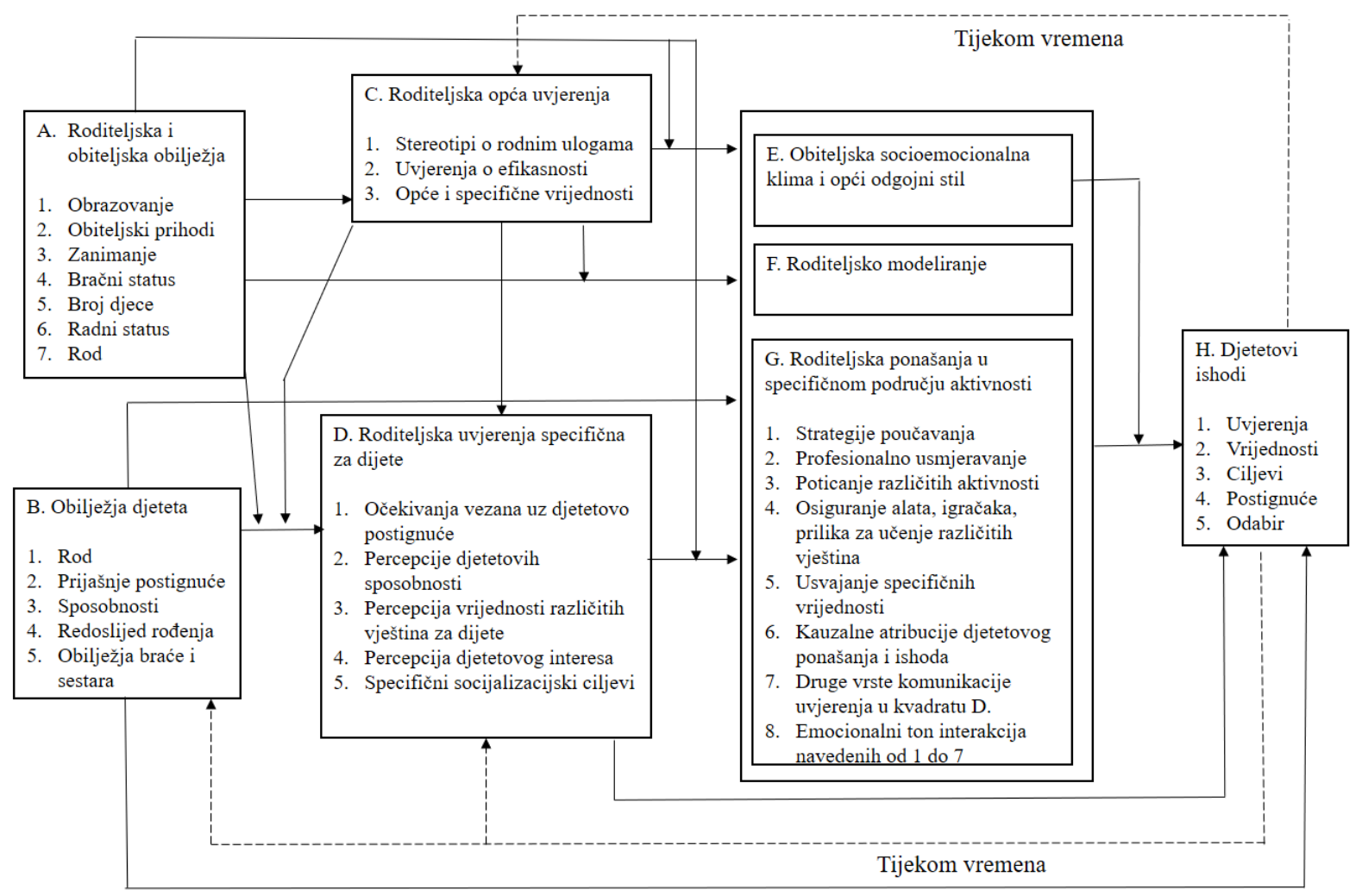

Slika 2. Model roditeljske socijalizacije dječjih obrazovnih ishoda (preuzeto iz Simpkins i sur., 2015a).

U opisima ovog modela često se ističu dvije osnovne roditeljske uloge - uloga roditelja kao "tumača stvarnosti" te uloga roditelja kao "osiguravatelja iskustava" (npr. Eccles, 1993; Fredricks i Eccles, 2004). Roditeljska uloga "tumača stvarnosti" ostvaruje se prvenstveno kroz roditeljska uvjerenja specifična za dijete kao što je percepcija djetetovih sposobnosti (Jacobs i Eccles, 2000). Naime, kada su djeca mala njihova sposobnost procjene vlastitih kompetencija nije dovoljno razvijena (Nicholls, 1978; prema Jacobs i Eccles, 2000) pa se djeca u velikoj mjeri oslanjaju na roditeljske interpretacije svoje izvedbe kao relevantan izvor za samoprocjenu (Jacobs i Eccles, 2000). Roditeljska uloga "osiguravatelja iskustava" odnosi se na već opisana roditeljska ponašanja u specifičnim područjima aktivnosti, kao što su roditeljsko poticanje interesa, zajednička uključenost roditelja $\mathrm{s}$ djetetom $\mathrm{u}$ aktivnosti te pribavljanje različitih materijala i iskustava za dijete (Eccles, 1993).

Kao što je vidljivo iz Slike 2, osim izravnih i neizravnih veza, model roditeljske socijalizacije dječjih obrazovnih ishoda pretpostavlja i postojanje interakcija između određenih roditeljskih konstrukata pri njihovom utjecaju na dječje obrazovne ishode. Primjerice, pretpostavlja se da će afektivna i motivacijska klima koja prevladava u obitelji utjecati na to do koje će mjere roditeljsko modeliranje aktivnosti te roditeljska ponašanja specifična za određeno 
područje djelovati na razvoj dječjih motivacijskih uvjerenja i sposobnosti (Simpkins i sur., 2015a). Ova moderatorska uloga obiteljske socioemocionalne klime oslikava pretpostavku da nije samo važno što roditelji prenose svojoj djeci, već i na koji način to prenose. Naime, kada u obitelji prevladava zdrava socioemocionalna klima, veća je vjerojatnost da će dijete biti motivirano internalizirati roditeljske ciljeve i vrijednosti te usvojiti ponašanja i aktivnosti koje roditelji modeliraju. $\mathrm{S}$ druge strane, pretjerana roditeljska kontrola i pritisak da dijete mora biti uspješno u određenom području mogu negativno utjecati na intrinzičnu vrijednost koju dijete pridaje aktivnostima u tom području te na razinu djetetovih uvjerenja o vlastitoj sposobnosti u području (Simpkins i sur., 2015a).

Nadalje, osim što se pretpostavlja da roditelji svoja opća uvjerenja ('kućica' C) prevode u uvjerenja specifična za dijete ('kućica' D), pretpostavka modela je i da roditeljska opća uvjerenja djeluju kao moderator poveznice između obilježja djeteta te roditeljskih uvjerenja specifičnih za dijete (Eccles, 1993). Primjerice, u istraživanju koje su proveli Yamamoto i Holloway (2010) roditeljska obrazovna očekivanja vezana uz njihovo dijete bila su snažnije povezana $\mathrm{s}$ djetetovim ranijim obrazovnim postignućem u slučaju kada su roditelji vjerovali da je sposobnost naslijeđena, a ne promjenjiva dispozicija, kada su iskazivali povjerenje u djetetovu školu i kada su vjerovali da mogu utjecati na obrazovno postignuće svoje djece.

Nadalje, iako je $u$ istraživanjima u području obrazovanja obiteljski SES dominantno tretiran kao prediktorska varijabla, iz Slike 2 je vidljivo da model roditeljske socijalizacije dječjih obrazovnih ishoda postavlja distalne roditeljske karakteristike i kao moderatorsku varijablu odnosa između dječjih karakteristika (npr. prošlog postignuća) i roditeljskih uvjerenja specifičnih za dijete te odnosa između roditeljskih uvjerenja i roditeljskih ponašanja. Primjerice, može se očekivati da je zbog manje financijskih i socijalnih resursa roditeljima nižeg SES-a teže uvijek uspješno prevoditi svoja uvjerenja, vrijednosti i odgojne ciljeve u uspješne odgojne prakse (Eccles, 1993). Stoga bi poveznica između ova dva skupa roditeljskih varijabli trebala biti snažnija kod roditelja koji su višeg SES-a. Istraživanja također pokazuju da je kod roditelja višeg SES-a snažnija poveznica između djetetovog prošlog školskog postignuća i roditeljskih uvjerenja specifičnih za dijete, kao što je očekivanje djetetovog budućeg uspjeha (Yamamoto i Holloway, 2010).

Iako su mnoge komponente modela roditeljske socijalizacije dječjih obrazovnih ishoda empirijski istražene, i dalje postoji nekoliko područja za koje nedostaje empirijska provjera. Primjerice, nedostaje istraživanja u kojima bi se paralelno ispitao utjecaj proksimalnih $\mathrm{i}$ distalnih roditeljskih karakteristika na učeničke obrazovne ishode te na specifična roditeljska ponašanja ('kućica' G) (Eccles, 2007). Naime, većina se istraživanja do sada bavila poveznicom 
između egzogenih elemenata modela ('kućice' A i B) i ostalih konstrukata koji se odnose na roditelje i djecu (Wigfield i sur., 2015). Drugo, rijetko su unutar istog modela testirani različiti mehanizmi proksimalnih roditeljskih utjecaja, odnosno, utjecaji različitih roditeljska uvjerenja, ali i roditeljskih praksi (Simpkins i sur., 2012). Treće, relativno je mali broj radova u kojima je unutar jednog istraživanja provjeren utjecaj različitih komponenti roditeljskih ponašanja na dječje obrazovne ishode (Simpkins i sur., 2015a; Wigfield i sur., 2015). Saznanja o utjecajima specifičnih roditeljskih ponašanja, usko vezanih uz STEM područje, su također ograničena (Simpkins i sur., 2005). Wigfield i suradnici (2015) napominju da je nedostatak dosadašnjih istraživanja roditeljske socijalizacije dječje motivacije za postignućem i to što ih se većina bavi općim konstruktima, a ne konstruktima u specifičnom području aktivnosti. Primjerice, postoji veliki broj istraživanja u kojima su SES te opći socijalizacijski stilovi povezivani s općim školskim uspjehom te općim motivacijskim konstruktima kod učenika kao što su školska uključenost ili naučena bespomoćnost (Wigfield i sur., 2015). Međutim, istraživanja bi se trebala usmjeriti na specifična područja. Naime, iako su roditeljske opće socijalizacijske prakse važne, roditeljska uvjerenja i ponašanja u specifičnim obrazovnim područjima, kao što su primjerice predmeti prirodoslovnog područja, su snažniji prediktori učeničkih obrazovnih ishoda u tim predmetima nego roditeljski opći obrazovni ciljevi (Archer i sur., 2012).

U narednim ćemo poglavljima detaljnije opisati teorijske odnose i empirijske nalaze vezane uz tri skupine konstrukata vezanih uz roditelje iz modela roditeljske socijalizacije dječjih obrazovnih ishoda koje će biti obuhvaćene ovim istraživanjem - distalne roditeljske karakteristike, roditeljska uvjerenja specifična za dijete u STEM području te roditeljska ponašanja u STEM području.

\section{6. 2. Distalne roditeljske karakteristike}

Model roditeljske socijalizacije dječjih obrazovnih ishoda opisuje složen mehanizam utjecaja preko kojeg distalne roditeljske karakteristike, kao što su roditeljsko genetsko nasljeđe, obrazovanje, pripadnost određenoj kulturalnoj skupini, zanimanje, financijski prihodi i druga obilježja utječu na krajnje učeničko obrazovno postignuće. Taj se utjecaj prvenstveno ostvaruje preko roditeljskih uvjerenja i ponašanja (Eccles, 2005). Naime, roditeljska uvjerenja i ponašanja, koja su značajno oblikovana distalnim obilježjima roditelja, utječu na dječja motivacijska uvjerenja i vještine. Dječja motivacijska uvjerenja i vještine pak određuju uključenost djeteta u različite aktivnosti, što naposljetku određuje i djetetovo obrazovno postignuće (Eccles, 2005). Od svih indikatora SES-a, stupanj obrazovanja roditelja do sada se 
pokazao najvažnijim u predviđanju učeničkih obrazovnih ishoda (Davis-Kean, 2005). Empirijska istraživanja su potvrdila da djeca iz obitelji nižeg SES-a postižu niže rezultate u nastavnim predmetima STEM područja (OECD, 2007). Primjerice, utvrđeno je da se razlike u učeničkom postignuću iz matematike koje su povezane sa SES-om održavaju tijekom godina školovanja (Shin, Davison, Long, Chan i Heistad, 2013). Pored toga, učenici iz obitelji nižeg SES-a rjeđe se odlučuju za napredne kurikulume iz matematike i prirodnih predmeta (Bozick i Ingels, 2008; Simpkins i sur., 2006; Tyson, Lee, Borman i Hanson, 2007). Posljedično, učenici nižeg SES-a imaju manje mogućnosti za ostvarenje daljnjeg obrazovanja i karijere u STEM području (Gorard i See, 2009).

U području istraživanja distalnih roditeljskih utjecaja postoji nekoliko nedovoljno istraženih pitanja te nekonzistentnih nalaza. Prvo, relativno se rijetko u obzir uzimaju raznoliki roditeljski medijacijski mehanizmi u podlozi poveznice između SES-a i učeničkih obrazovnih ishoda (Davis-Kean, 2005). Prijašnja istraživanja ukazuju na medijacijsku ulogu roditeljskih očekivanja uspjeha, odnosno uvjerenja o djetetovoj sposobnosti u zadanom području. Naime, obrazovaniji roditelji imaju viša obrazovna očekivanja od svoje djece, koja pak predviđaju djetetovo postignuće (Alexander, Entwisle i Bedinger, 1994; Carolan i Wasserman, 2015; Davis-Kean, 2005). Pokazalo se da viša roditeljska obrazovna očekivanja predviđaju kasnije učeničko postignuće čak i uz kontrolu prethodnog postignuća učenika (Briley, Harden i TuckerDrob, 2014). Važnost roditeljskih uvjerenja vezanih uz dijete kao medijacijskih mehanizama obiteljskog SES-a potvrđena je i u STEM području (Davis-Kean, 2005; Halle, Kurtz-Costes i Mahoney, 1997).

Uloga specifičnih roditeljskih ponašanja u objašnjavanju poveznice između distalnih roditeljskih karakteristika i učeničkog postignuća u predmetima STEM područja manje je jasna. Primjerice, postoje nekonzistentni nalazi o tome razlikuje li se razina roditeljske uključenosti s obzirom na obiteljski SES (Perera, Bomhoff i Lee, 2014). Neka su istraživanja tako pokazala da je niži SES povezan s višom razinom roditeljske uključenosti u djetetove aktivnosti vezane uz školu (npr. Silinskas, Leppänen, Aunola, Parrila i Nurmi, 2010), dok u drugim istraživanjima nije pronađena poveznica između SES-a i frekvencije roditeljskog pomaganja s domaćom zadaćom (npr. Epstein i Van Voorhis, 2001; Lee i Bowen, 2006).

Drugo nedovoljno istraženo područje odnosi se na ulogu SES-a u formiranju dječje motivacije. Naime, iako je poveznica između SES-a i učeničkog obrazovnog postignuća često istraživana, mnogo je manje istraživanja u kojima je ispitano na koji je način SES povezan s dječjim motivacijskim uvjerenjima u različitim područjima obrazovanja (Eccles, 2005). Međutim, kao što je već spomenuto, prema modelu roditeljske socijalizacije dječjih obrazovnih 
ishoda, distalne roditeljske karakteristike bi trebale utjecati ne samo na postignuće, već i na učenička motivacijska uvjerenja u području (Eccles, 2005). Pored toga, u potpunom razumijevanju poveznice između SES-a i učeničkog postignuća i odabira, u obzir treba uzeti ne samo roditeljska ponašanja i uvjerenja, već i učenička motivacijska uvjerenja (Eccles, 2005). Primjerice, Svoboda, Rozek, Hyde, Harackiewicz i Destin (2016) potvrdili su hipotezu da se povezanost između razine obrazovanja roditelja i učeničkih odabira nastavnih sadržaja STEM područja može dijelom objasniti kombinacijom i roditeljskih i učeničkih uvjerenja u STEM obrazovnom i profesionalnom području.

\section{6. 3. Roditeljska uvjerenja specifična za dijete}

Kao što je već bilo riječi, model Eccles i suradnika razdvaja opća roditeljska uvjerenja te uvjerenja specifična za dijete. U ovom ćemo se istraživanju baviti samo potonjim roditeljskim uvjerenjima u STEM obrazovnom području. Dvije značajne meta-analize u psihologiji obrazovanja (Fan i Chen, 2001; Hill i Tyson, 2009) sugeriraju da roditeljska uvjerenja specifična za dijete, kao što su očekivanja vezana uz djetetovo postignuće te obrazovne aspiracije roditelja, imaju snažniji utjecaj na učeničko postignuće nego konkretne roditeljske prakse kao što je roditeljska uključenost kod kuće i u školi. Ova su se roditeljska uvjerenja pokazala značajnim i konzistentnim prediktorima ne samo učeničkog postignuća, već i motivacije za postignućem (Simpkins i sur., 2015a). Važno je napomenuti da se prediktivna snaga ovih roditeljskih uvjerenja zadržava čak i kada se u obzir uzmu i druge relevantne varijable koje bi mogle objasniti ovu povezanost, kao što je prošlo školsko postignuće učenika ili rod učenika (Simpkins i sur., 2015a). Valja također naglasiti da se prema modelu Eccles i suradnika ova roditeljska uvjerenja uvijek operacionaliziraju u kontekstu procjene individualnog djeteta u jasno određenom području aktivnosti (Wigfield i sur., 2015). Naime, roditelji mogu imati uvjerenje da je njihovo dijete vrlo sposobno u području matematike, ali da ima ograničene vještine u području čitanja (Simpkins i sur., 2015a).

U istraživanjima u STEM obrazovnom području do sada su korištene različite operacionalizacije roditeljskih uvjerenja specifičnih za dijete, kao što su roditeljska percepcija djetetovih sposobnosti u području (npr. Frome i Eccles 1998; Jacobs i Eccles 1992), roditeljska očekivanja djetetovog uspjeha u području (npr. Bleeker i Jacobs 2004; Jodl, Michael, Malanchuk, Eccles i Sameroff, 2001; Simpkins i sur., 2006) te roditeljska percepcija djetetovih vrijednosti i truda u području (npr. Eccles, Adler i Kaczala, 1982; Tenenbaum i Leaper, 2003). Istraživanja su pokazala da se motivacijska uvjerenja učenika u STEM području mogu 
predvidjeti na temelju roditeljskih evaluacija dječjih sposobnosti u STEM području (Bhanot i Jovanovic, 2009; Bleeker i Jacobs, 2004; Frome i Eccles, 1998; Jacobs i Eccles, 1992). Čak se pokazalo da su učenička uvjerenja o vlastitoj sposobnosti u matematici u većoj mjeri direktno povezana s uvjerenjima njihovih roditelja o njihovoj matematičkoj sposobnosti, nego s učeničkim prijašnjim postignućem u matematici ili s rodom učenika (Eccles i sur., 1982; Frome i Eccles, 1998).

Model roditeljske socijalizacije dječjih obrazovnih ishoda pretpostavlja da kroz svoja uvjerenja vezana za dijete roditelji imaju tzv. ulogu "tumača stvarnosti". Ova je hipoteza i empirijski potvrđena. Primjerice, Frome i Eccles (1998) su pronašli da su roditeljske percepcije djetetove matematičke sposobnosti djelovale kao medijatori u objašnjavanju povezanosti između djetetovih ocjena iz matematike i djetetove samoprocjene u matematici te vrijednosti zadatka u području matematike. Ovaj rezultat sugerira da roditeljska uvjerenja o djetetovoj sposobnosti uistinu mogu utjecati na način kako dijete interpretira stvarnost. Drugim riječima, čini se da su djetetove percepcije samoga sebe utemeljene ne samo na informaciji o objektivnom uspjehu, već i na roditeljskim interpretacijama ove stvarnosti.

U jednoj od rijetkih longitudinalnih studija u ovom području, Bleeker i Jacobs (2004) su potvrdile dugoročan efekt roditeljskih uvjerenja vezanih uz dijete. Pokazalo se da su majčine percepcije sposobnosti djeteta u srednjoškolskim predmetima matematike i prirodoslovlja bile povezane sa samoprocjenom adolescenata u ovim školskim područjima u dobi između 16 i 17 godina. Nadalje, ove su samoprocjene adolescenata imale ulogu medijatora između majčine inicijalne evaluacije djeteta i kasnije samoefikasnosti u karijeri iz STEM područja kada su mladi bili u dobi između 24 i 25 godina. Majčina očekivanja o djetetovom uspjehu u karijerama vezanim uz matematiku također su bila povezana s vjerojatnošću da će djeca u adolescentskoj dobi izabrati karijeru u području prirodoslovlja umjesto karijere u nekom drugom području. U ovom je istraživanju dobivena i interakcija između majčine percepcije djetetove sposobnosti i roda učenika u predviđanju kasnijih karijernih odabira u adolescentskoj dobi. Naime, pokazalo se da je u slučaju djevojaka niža majčina evaluacija djetetove uspješnosti u karijeri povezanoj s matematikom bila povezana s nižom vjerojatnošću da će djevojke kasnije izabrati karijeru u području prirodoslovlja u odnosu na karijeru koja nije u ovoj domeni. Zanimljivo je da je u slučaju dječaka majčina inicijalna evaluacija imala minimalan efekt u njihovim kasnijim karijernim odabirima.

Neka istraživanja sugeriraju da roditeljska uvjerenja mogu imati različiti utjecaj na oblikovanje djetetovih uvjerenja o vlastitoj sposobnosti tijekom različitih faza školovanja. U longitudinalnom istraživanju koje su proveli Gniewosz, Eccles i Noack (2011) ispitivan je 
utjecaj djetetovih ocjena te utjecaj majčine percepcije djetetovih sposobnosti u matematici (i engleskom) na djetetova akademska uvjerenja o sposobnosti tijekom i nakon tranzicije iz osnovne u srednju školu. Pokazalo se da tijekom tranzicije utjecaj školskih ocjena na akademsko samopoimanje opada, dok utjecaj majčine evaluacije djetetovih sposobnosti raste. Zanimljiv je nalaz da nakon što je obrazovna tranzicija završena, utjecaj djetetovih ocjena opet počinje rasti, a utjecaj majčine evaluacije slabjeti. Autori ovaj nalaz pripisuju tome da učenici tijekom obrazovne tranzicije gube svoj uobičajeni referentni okvir i stoga se u većoj mjeri oslanjaju na roditeljske procjene.

Kada govorimo o povezanosti između roditeljskih uvjerenja specifičnih za dijete i učeničkog postignuća, treba reći da model roditeljske socijalizacije dječjih obrazovnih ishoda pretpostavlja da je ta poveznica posredovana preko roditeljskog utjecaja na učeničku motivaciju za postignućem (Eccles, 2007). Međutim, u novijim se istraživanjima u području matematike pokazalo da roditeljska uvjerenja previđaju učeničko postignuće ne samo preko svog utjecaja na učeničku motivaciju u području, već i da je njihov efekt na postignuće i izravan (npr. Froiland i Davison, 2016; Froiland, Peterson i Davison, 2013; Neuenschwander, Vida, Garrett i Eccles 2007). Thomas i Strunk (2017) su pronašli da su roditeljska očekivanja pozitivno predviđala učeničko školsko postignuće u prirodoslovlju te da su pritom imala snažniji prediktivni učinak nego učenička samoefikasnost u prirodoslovlju.

\section{6. 4. Roditeljska ponašanja}

U dosadašnjim su istraživanjima u STEM području korištene različite operacionalizacije roditeljskih ponašanja, kao što je modeliranje aktivnosti, zajednička uključenost roditelja i djeteta u aktivnosti te roditeljsko poticanje djetetovih interesa u STEM području. Roditeljsko modeliranje se odnosi na samostalno uključivanje roditelja u aktivnosti, bez uključivanja djeteta (Jacobs i Bleeker, 2004). Eksperimentalna istraživanja u psihologiji potvrđuju važnost ponašanja odraslih osoba kao modela za dječje učenje ponašanja (Bandura i Walters, 1963; Gerull i Rapee, 2002; Hoogerheide, van Wermeskerken, Loyens i van Gog, 2016). Iako dijete nije aktivni sudionik, samim uključivanjem u pojedine aktivnosti roditelji mogu značajno utjecati na vrijednosni odnos djece prema istim tim aktivnostima s obzirom da većina male djece teži tome da budu poput svojih roditelja (Eccles, 1993). Kroz odabir između različitih dostupnih aktivnosti, način na koje provode slobodno vrijeme te kroz komuniciranje vlastite kompetentnosti u tim aktivnostima, roditelji djeci šalju snažnu poruku o tome koje aktivnosti imaju visoku vrijednost te koji su prihvatljivi načini provođenja slobodnog vremena (Jacobs i 
Bleeker, 2004). Također, opažanjem roditeljskih ponašanja djeca mogu ta ponašanja početi imitirati i u konačnici preuzeti kao dio svog repertoara aktivnosti i ponašanja (Jacobs i Bleeker, 2004). Pritom, zbog tendencije da se identificiraju s vlastitim spolom, dječaci i djevojčice mogu razviti različite vrijednosti prema pojedinim aktivnostima kao posljedicu različitog modeliranja aktivnosti od strane ženskog, odnosno muškog roditelja.

Dosadašnja istraživanja potvrdila su značaj roditeljskog modeliranja u STEM području. Primjerice, frekvencija roditeljskog korištenja računala pokazala se povezanom s dječjom namjerom korištenja računala (Pulos i Fisher, 1993). Roditeljska uključenost u matematičke aktivnosti pozitivno je predviđala učeničko očekivanje postignuća u matematici (Eccles i sur., 1982). Međutim, nalazi istraživanja Eccles i suradnika u području matematike sugeriraju da je roditeljski utjecaj na dječja motivacijska uvjerenja ipak veći kroz ranije raspravljenu roditeljsku ulogu "tumača stvarnosti" nego kroz ulogu modela za pojedine aktivnosti (Eccles, 1993).

Također, čini se da za razliku od nekih drugih specifičnih roditeljskih ponašanja, modeliranje ima slabiju ulogu u oblikovanju djetetovih ishoda u STEM području. Primjerice, u istraživanju Simpkins i suradnica (2005) roditeljska uključenost s djetetom u aktivnosti, roditeljsko pribavljanje STEM materijala te roditeljsko poticanje djetetovih interesa u STEM području imali su važniju ulogu u objašnjavanju razlika u dječjoj participaciji u STEM aktivnostima nego roditeljsko modeliranje aktivnosti u STEM području. Ovaj se nalaz, između ostalog, može objasniti time da je dječje usvajanje roditeljskih aktivnosti u STEM području isključivo kroz opažanje roditelja otežano budući da su mnoge aktivnosti ove vrste znatno kompleksnije u odnosu na druga ponašanja koja djeca obično usvajaju opažanjem, kao što su primjerice sportske ili umjetničke aktivnosti (Simpkins i sur., 2005).

Osim modeliranja, roditelji mogu na dječje ishode u određenoj domeni aktivnosti utjecati i kroz igračke, materijale, opremu i iskustva koje svojoj djeci osiguravaju (Eccles, 1993). Ovaj roditeljski mehanizam utjecaja se često opisuje kao "struktura mogućnosti" (Jacobs, Davis-Kean, Bleeker, Eccles i Malanchuk, 2005). Primjerice, roditelji koji visoko vrednuju matematiku mogu svojoj djeci pribavljati računalne igre, društvene igre i druge manipulativne materijale koji uključuju matematiku te time djeci osigurati priliku da kroz igru budu u doticaju s matematičkim sadržajima i izvan škole (Jacobs i Bleeker, 2004). Uzimajući $\mathrm{u}$ obzir djetetov spol, dob, kohortu te roditeljska uvjerenja vezana uz matematiku i prirodoslovlje, Jacobs i Bleeker (2004) su pronašle da je majčino kupovanje igračaka povezanih s matematikom i prirodoslovljem bilo povezano s višom uključenosti djece u matematičke $\mathrm{i}$ prirodoslovne aktivnosti dvije godine poslije. Kvalitativno istraživanje koje se temeljilo na intervjuima s djecom pokazalo je da je u obiteljima u kojima su interesi za STEM područje 
najizraženiji, izloženost djece iskustvima vezanim uz STEM područje također najveća. U takvim obiteljima postoji visoka dostupnost časopisa i knjiga iz STEM područja, a članovi obitelji često gledaju TV programe koji prikazuju STEM sadržaje te čitaju vijesti koje se tiču tema iz STEM područja (Archer, 2010).

Roditelji također mogu djetetu osigurati dodatnu uključenost u aktivnosti povezane sa STEM sadržajima kroz specijalizirane klubove, natjecanja u STEM obrazovnom području i slične aktivnosti. Izvannastavne aktivnosti imaju i širi domet od pozitivnog utjecaja na dječju motivaciju, izbore i postignuće. Naime, ovakva iskustva također mogu pozitivno utjecati na djetetov socijalni razvoj i odnose s vršnjacima te služe kao zaštitni čimbenik od odustajanja od daljnjeg školovanja (Jacobs i sur., 2005). Eccles (1993) navodi da izloženost djece različitim aktivnostima, igračkama i materijalima djeluje na njihova motivacijska uvjerenja i kasnije izbore sličnih aktivnosti kroz procese povezane s klasičnim i operantnim uvjetovanjem te poznatost aktivnosti.

Međutim, kao što je već bilo riječi u opisu modela roditeljske socijalizacije dječjih obrazovnih ishoda, usvajanje pozitivnih motivacijskih uvjerenja kroz izloženost različitim iskustvima koje roditelji osiguravaju uvelike ovisi o afektivnoj i motivacijskoj klimi koju roditelji stvaraju dok je dijete u doticaju s ovim iskustvima. Ako se učenje događa u pozitivnom afektivnom okruženju, veća je vjerojatnost da će dijete razviti interes prema aktivnosti (Eccles, 1993). Visoko kontrolirajuća roditeljska ponašanja i pritisak da dijete bude uspješno u aktivnosti mogu negativno utjecati na djetetovu intrinzičnu motivaciju za bavljenje aktivnošću, djetetova uvjerenja o vlastitim sposobnostima te stvoriti negativan stav prema aktivnosti kroz proces uvjetovanja (Grolnick, 2003; Lepper i Henderlong, 2000; prema Eccles, 2007).

Jedan od roditeljskih bihevioralnih mehanizama je i zajedničko sudjelovanje roditelja i djece u različitim svakodnevnim aktivnostima kao što je, primjerice, zajedničko čitanje knjiga ili posjeti događanjima povezanima s konkretnim područjem, kao što je posjet prirodoslovnom muzeju (Simpkins i sur., 2012). Zajedničko sudjelovanje s djetetom u aktivnostima daje roditelju priliku da verbalno potiče dijete, izravno poučava dijete određenim vještinama $i$ pomaže djetetu da se kreće kroz zone proksimalnog razvoja (Cole, 1996; prema Simpkins i sur., 2005). Prema teoriji Leva Vygotskog (1978), zona proksimalnog razvoja predstavlja prostor između zadataka koje dijete može samostalno obaviti i zadataka u kojima mu je potrebno vođenje i pomoć odraslih. Kroz pružanje adekvatne pomoći i strukture u prolaženju zona proksimalnog razvoja, roditelji pomažu djetetu da uspješnije usvaja nova znanja i vještine, razvija uvjerenja o vlastitim sposobnostima te bude uspješnije u budućim zadacima (Grolnick i Ryan, 1989; prema Simpkins i sur., 2005). Istraživanja pokazuju da u akademskom području 
roditeljska uključenost može pozitivno djelovati i na postignuće, ali i na uspješnost u kognitivnoj obradi informacija (Eccles i Harold, 1996). Tako se pokazalo da djeca brže i s višom razinom samopouzdanja usvajaju nove sadržaje iz prirodoslovlja kada zajedno s roditeljima sudjeluju u aktivnostima povezanim s ovim područjem (Dierking i Falk, 1994).

Korištenjem objašnjenja u aktivnostima s djecom u STEM području, roditelji mogu djetetu olakšati usvajanje vještine znanstvenog rješavanja problema te mu pomoći $u$ rekonstrukciji naivnih teorija koje većina djece ima u STEM području (Crowley, Callanan, Tenenbaum i Allen, 2001). Zajedničko sudjelovanje roditelja s djecom u STEM području pozitivno je povezano ne samo s dječjim postignućem, nego i s razvojem pozitivnih vrijednosti i interesa za STEM područje (Crowley i sur., 2001). Međutim, bez obzira na ove pozitivne efekte, roditelji u većoj mjeri sudjeluju s djecom u drugim akademskim aktivnostima, kao što je zajedničko čitanje priča, nego u matematičkim aktivnostima (Berkowitz i sur., 2015). Rasprostranjen stav među roditeljima je da škola ima primarnu ulogu u matematičkom obrazovanju te da je roditeljska uloga u dječjem usvajanju matematičkih sadržaja puno manje važna nego podrška roditelja u dječjem ovladavanju čitanjem (Cannon i Ginsburg, 2008).

Iako većina roditelja vjeruje da su prirodoslovni sadržaji neizostavan dio svakodnevnog života, roditeljska uključenost u dječje obrazovanje iz prirodoslovnih predmeta još je rjeđa u odnosu na uključenost i u matematici i u čitanju. Roditelji također imaju relativno malo saznanja o tome što njihova djeca uče iz prirodoslovnih predmeta u školi (American Association for the Advancement of Science, 2001). Osim nedostatka roditeljske kompetentnosti $\mathrm{u}$ ovom području, razlog slabe roditeljske uključenosti $\mathrm{u}$ prirodoslovno obrazovanje njihove djece može ležati i u negativnim osobnim iskustvima s prirodoslovnim predmetima o kojima mnogi roditelji izvještavaju (Cardoso i Solomon, 2002). Istraživanja također pokazuju da je roditeljska uključenost u aktivnosti njihove djece u STEM području značajno češća kada su djeca mlađa (Jacobs i Bleeker, 2004).

Iako roditeljska uključenost $\mathrm{u}$ dječje aktivnosti generalno predstavlja pozitivan socijalizacijski utjecaj, neophodno je da dijete tu uključenost percipira kao izraz roditeljske podrške kako bi konačni efekti u pogledu dječje motivacije i postignuća bili pozitivni (Campbell i Mandel, 1990). Također, manje konzistentni pozitivni efekti u odnosu na ostale oblike roditeljske uključenosti dobiveni su za roditeljsku uključenost u dječje školske obaveze, kao što je roditeljsko pomaganje s domaćom zadaćom. Meta-analiza koja je uključivala istraživanja provedena s učenicima viših razreda osnovne škole (Hill i Tyson, 2009), pokazala je da je od svih oblika roditeljske uključenosti jedino roditeljsko pomaganje s domaćom zadaćom bilo negativno povezano $\mathrm{s}$ učeničkim postignućem $\mathrm{u}$ različitim obrazovnim 
područjima. Ovaj se nalaz možda može pripisati razlozima zbog kojih roditelji pružaju pomoć sa zadaćom. Naime, roditelji najčešće povećavaju svoju uključenost u zadaće u periodima kada djeca imaju poteškoće u školi (Pomerantz i Grolnick, 2017). Specifično za STEM područje, Bhanot i Jovanovic (2005) su pronašli da je roditeljsko nadziranje domaće zadaće bilo povezano s lošijom percepcijom vlastite matematičke sposobnosti kod učenika, ali je taj nalaz dobiven samo za djevojčice. Istraživanja koja su se bavila roditeljskim ponašanjima u okviru modela roditeljske socijalizacije dječjih obrazovnih ishoda Eccles i suradnika, većinom su roditeljsku uključenost operacionalizirala tako da se ona odnosila na šire područje aktivnosti u STEM području (npr. zajednički rad roditelja i djeteta na računalu, posjet muzejima, zajedničko gledanje znanstvenih emisija i sl.), a ne usko na roditeljsku uključenost u djetetove obaveze vezane uz konkretan nastavni predmet (npr. Simpkins i sur., 2005; Simpkins i sur. 2012). Međutim, slijedeći pretpostavku modela roditeljske socijalizacije dječjih obrazovnih ishoda, prema kojoj pojedina ponašanja roditelja predstavljaju sredstvo preko kojeg roditelji djetetu šalju poruke o svojim procjenama djetetovih sposobnosti (Simpkins i sur. 2015a), možemo očekivati da visoka roditeljska uključenost u djetetove školske obaveze može djetetu odašiljati poruku da ga roditelj ne vidi dovoljno kompetentnim $u$ danom predmetu i time negativno djelovati na djetetova motivacijska uvjerenja vezana uz taj predmet.

Prema modelu roditeljske socijalizacije dječjih obrazovnih ishoda, roditeljsko verbalno poticanje i podrška dječjih aktivnosti i interesa pozitivno djeluju na dječja motivacijska uvjerenja, što posljedično pozitivno utječe i na vjerojatnost da će se dijete baviti aktivnošću i u budućnosti (Eccles, 1993). Pored toga, roditeljevo poticanje i ohrabrivanje djeteta u bavljenju određenom aktivnošću djetetu može signalizirati da je riječ o aktivnosti koju roditelj visoko vrednuje, što olakšava internalizaciju roditeljskih vrijednosti (Simpkins i sur., 2005). Poticanje aktivnosti također može stvoriti pozitivno afektivno stanje kod djeteta, što procesima klasičnog uvjetovanja dovodi do povezivanja pozitivnih osjećaja sa samom aktivnošću (Simpkins i sur., 2005). Pokazalo se da je roditeljsko poticanje obrazovanja u području matematike te odabira zanimanja vezanog uz matematiku i prirodoslovlje pozitivno povezano s dječjim očekivanjima uspjeha i dječjom samoefikasnosti u matematici (Turner, Steward i Lapan, 2004). Roditeljske rasprave s djetetom o predmetima i karijerama u STEM području mogu pozitivno djelovati na dječje vrednovanje STEM područja i dječju participaciju u izvannastavnim aktivnostima u STEM području, kao što su posjeti prirodoslovnim muzejima i znanstvenim sajmovima (George i Kaplan, 1998). Roditeljsko poticanje u STEM području posebice je važno za razvoj djetetovih karijernih aspiracija vezanih uz ovo područje (Paa i McWhirter, 2000) te može imati 
vrlo važnu ulogu u ustrajnosti djevojaka da nastave s obrazovnim i profesionalnim putem $\mathrm{u}$ nekoj od STEM disciplina (Rayman i Brett, 1995).

\section{6. 5. Odnos između roditeljskih uvjerenja i ponašanja u STEM području}

U prijašnjim se istraživanjima pokazalo da su različiti oblici roditeljskih uvjerenja pozitivno povezani s različitim oblicima roditeljskih ponašanja u STEM području. Primjerice, pokazalo se da su pozitivni roditeljski stavovi prema STEM području povezani s roditeljskim posjećivanjem prirodoslovnih muzeja s djetetom (Szechter i Carey, 2009) i uključenosti u dječju domaću zadaću iz predmeta STEM obrazovnog područja (Cardoso i Solomon, 2002). Bhanot i Jovanovic (2005) su pronašli da je majčina percepcija djetetove sposobnosti u matematici bila pozitivno povezana $\mathrm{s}$ majčinom uključenosti $\mathrm{u}$ djetetove obaveze iz matematike. Međutim, pretpostavka modela roditeljske socijalizacije dječjih obrazovnih ishoda je ne samo postojanje poveznice između roditeljskih uvjerenja i ponašanja, već se pretpostavlja i da kroz svoja ponašanja i prakse roditelji djetetu komuniciraju vlastite vrijednosti, uvjerenja i ciljeve vezane uz neko područje (Eccles, 1993). Iz modela tako proizlaze dva medijacijska slijeda utjecaja: roditeljska ponašanja bi trebala posredovati u odnosu između dječjih motivacijskih uvjerenja i roditeljskih uvjerenja, a dječja motivacijska uvjerenja bi trebala imati ulogu medijatora u odnosu između roditeljskih i dječjih ponašanja u danom području aktivnosti (Simpkins i sur., 2012).

Međutim, gotovo da ne postoje istraživanja u kojima je unutar jedinstvenog modela provjerena cjelovita sekvenca utjecaja roditeljska uvjerenja - roditeljska ponašanja - dječja uvjerenja - dječja ponašanja (Simpkins i sur., 2012). Jedino takvo istraživanje u STEM području koje smo pronašli pregledom literature je istraživanje koje su provele Simpkins i suradnice (2012). U ovom je istraživanju provjera modela roditeljske socijalizacije dječjih obrazovnih ishoda u području matematike dobila samo djelomičnu podršku. Naime, medijacijski učinak roditeljskih ponašanja u objašnjavanju poveznice između roditeljskih i učeničkih uvjerenja te medijacijski učinak učeničkih uvjerenja u objašnjavanju poveznice između roditeljskih i učeničkih ponašanja potvrđeni su samo u modelu u kojem je kao motivacijsko uvjerenje učenika postavljena subjektivna vrijednost zadatka, ali ne i u modelu s učeničkom samoefikasnosti u matematici. Zanimljivo je da je model dobio mnogo jaču podršku u izvanškolskim područjima aktivnosti, kao što su sport i glazba.

U istraživanju kojeg su proveli Bhanot i Jovanovic (2009) provjerena je samo medijacijska uloga roditeljskih ponašanja. Majčino poticanje u području prirodoslovlja nije se 
pokazalo kao značajan medijacijski mehanizam između majčinih percepcija djetetove sposobnosti u prirodoslovlju i dječjih samopercepcija. Nadalje, u istom istraživanju, majčine rasprave o korisnosti prirodoslovlja također nisu imale medijacijski učinak u objašnjavanju povezanosti između majčinih i djetetovih vrijednosti zadatka. Općenito, teorijska pretpostavka o medijacijskoj ulozi roditeljskih ponašanja u objašnjavanju poveznice između roditeljskih uvjerenja i učeničkih motivacijskih uvjerenja nije u istraživanjima dobila dovoljnu empirijsku podršku (Eccles, 1993). S time je izravno povezan problem što je malo istraživanja koja su do sada pokušala identificirati koja su to točno ponašanja preko kojih roditelji prenose svoja uvjerenja i vrijednosti o nekom području aktivnosti svojoj djeci (Lazarides i sur., 2015).

\section{6. 6. Rodna diferenciranost roditeljskih uvjerenja i ponašanja u STEM području}

U teorijskom radu ${ }^{7}$ Eccles i suradnika rod učenika ima vrlo važnu ulogu. Kao što je vidljivo iz prošlih poglavlja u kojima je bilo riječi o modelu očekivanja i vrijednosti, $u$ fokusu modela su rodne razlike na razini aritmetičke sredine, a ne rodne razlike u pristajanju modela (Wigfield i sur., 2015). Inicijalna pretpostavka Eccles i suradnika je da odnosi pretpostavljeni modelom u jednakoj mjeri vrijede za mušku i žensku djecu (Wigfield i sur., 2015). Međutim, pojavom sofisticiranih metoda obrade podataka kao što je strukturalno modeliranje, istraživači su počeli provjeravati postoji li diferencijacija u pristajanju modela s obzirom na rod učenika (Wigfield i sur., 2015). Veći broj istraživanja u STEM području potvrdio je da isti procesi socijalizacije vrijede za mušku i žensku djecu (Aunola, Nurmi, Lerkkanen i Rasku-Puttonen 2003; Chouinard i sur., 2007; Eccles i sur., 1982; Gladstone, Häfner, Turci, Kneißler i Muenks, 2018; Pesu, Aunola, Viljaranta i Nurmi, 2016; Simpkins i sur., 2005; Simpkins i sur., 2012; Simpkins i sur., 2015c). Međutim, u nekim su istraživanjima dobivene rodne razlike u ovim procesima. Primjerice, Lazarides i Ittel (2013) su pronašle da je roditeljsko vrednovanje matematike i prirodoslovlja bilo značajno povezano s dječjim interesom za matematiku, ali samo u slučaju djevojčica. U području odabira obrazovnog i karijernog puta, Bleeker i Jacobs (2004) su pokazale da je u slučaju djevojaka niža majčina procjena uspješnosti djevojaka u budućoj karijeri povezanoj s matematikom bila povezana s nižom vjerojatnošću da će djevojke kasnije izabrati karijeru u području prirodoslovlja u odnosu na karijeru izvan ovog područja. S

\footnotetext{
${ }^{7}$ Ovdje treba naglasiti da je model roditeljske socijalizacije dječjih obrazovnih ishoda uklopljen u model očekivanja i vrijednosti, odnosno, predstavlja njegov socijalizacijski dio. Stoga se u empirijskim radovima, u kojima se testiraju određene socijalizacijske hipoteze modela očekivanja i vrijednosti, autori nerijetko simultano referiraju na oba modela (vidi npr. Simpkins i sur., 2012). Iz tog se razloga rasprava o ulozi roda u teorijskom radu Eccles i suradnika odnosi na oba modela.
} 
druge strane, u slučaju mladića majčina inicijalna procjena je imala minimalan efekt na kasnije odabire mladića. U istraživanju kojeg su provele Taskinen, Dietrich i Kracke (2016) roditeljska očekivanja djetetovog uspjeha su bila snažnije povezana s interesom, uvjerenjem o vlastitoj sposobnosti i postignućem u prirodoslovlju kod dječaka nego kod djevojčica. Kako bi se razriješile ove nekonzistentnosti, potrebna su dodatna istraživanja kojima bi se ispitali moderatorski učinci roda učenika. Ova saznanja imaju i važne implikacije za praksu jer nam mogu otkriti treba li u intervencijskim programima ciljati na različite roditeljske prakse $u$ slučaju ženske, odnosno muške djece (Simpkins i sur., 2012).

Kada govorimo o razlikama na razini aritmetičke sredine, istraživanja pokazuju da roditelji dječaka u odnosu na roditelje djevojčica često procjenjuju da njihova djeca imaju višu razinu sposobnosti koje su potrebne za uspjeh u nastavnim predmetima STEM područja (Andre, Whigham, Hendrickson i Chambers, 1999; Bhanot i Jovanovic, 2009; Frome i Eccles, 1998) i STEM zanimanjima (Eccles, 1993), da je ovo područje manje zahtjevno njihovoj djeci (Tenenbaum i Leaper, 2003) te da su njihova djeca u većoj mjeri zainteresirana za STEM područje (Bhanot i Jovanovic, 2009; Eccles i Jacobs 1986; Tenenbaum i Leaper, 2003). S druge strane, roditelji djevojčica svoje kćeri doživljavaju kao više kompetentne u čitanju i jezicima nego roditelji dječaka (Eccles i sur., 1993a). U istraživanju koje su proveli Eccles i suradnici (1993a) roditelji ženske djece su procijenili da njihove kćeri moraju ulagati više truda kako bi ostvarile dobre ocjene iz matematike, nego roditelji dječaka. Razlika je bila u suprotnom smjeru za engleski jezik - roditelji dječaka su procijenili da njihovi sinovi moraju ulagati značajno više truda nego roditelji djevojčica. Slični rodne razlike u roditeljskim uvjerenjima o potrebnom trudu djeteta pronađene su i za prirodoslovne predmete (Goodnow, 1990). Rodno uvjetovane razlike u roditeljskim uvjerenjima rastu s djetetovom dobi (Frome i Eccles, 1998). Eccles, Jacobs i Harold (1990) su primjerice pronašle da se roditeljske percepcije o sposobnostima njihove djece ne razlikuju kada su djeca mala, no počinju se razlikovati kad djeca dostignu dob od oko 12 godina. Ova uvjerenja su često nepovezana s učeničkim stvarnim uspjehom u STEM području. Tome svjedoči nalaz istraživanja u kojem su roditelji djevojčica imali niže percepcije matematičke sposobnosti svoje djece nego roditelji dječaka i to čak kada su djevojčice ostvarivale bolji školski uspjeh u matematici nego dječaci (Frome i Eccles, 1998). Kao potencijalna objašnjenja ovakvih nalaza Eccles (2005) navodi različite kauzalne atribucije koje roditelji pripisuju uspjehu, odnosno, neuspjehu muške i ženske djece u različitim aktivnostima te općim rodnim stereotipima koje roditelji zastupaju. Naime, pokazalo se da što su roditelji više atribuirali djetetov uspjeh u matematici trudu (ovaj tip atribucije je bio više izražen u slučaju kćeri nego sinova), to su godinu dana kasnije iskazivali nižu percepciju djetetove 
matematičke sposobnosti (Yee i Eccles, 1988). S druge strane, roditelji dječaka su u većoj mjeri djetetovo matematičko postignuće atribuirali talentu nego što su to činili roditelji djevojčica. Što su roditelji više zastupali ovaj tip atribucije, to je bila veća vjerojatnost da će svoje dijete procijeniti kao talentirano za matematiku godinu dana kasnije.

Jacobs i Eccles (1992) su potvrdile značajnu interakciju između roditeljskih općih stereotipnih uvjerenja i roda učenika u predviđanju roditeljske percepcije djetetove sposobnosti. Naime, roditelji koji su zastupali tipične rodne stereotipe precjenjivali su matematičku sposobnost svog djeteta u slučaju kada je dijete bilo dječak, a podcjenjivali u slučaju kada je dijete bilo djevojčica. Istraživanja su pokazala da čak i roditelji vrlo male djece zastupaju opće rodne stereotipe o dječjim sposobnostima. U kros-kulturalnom istraživanju koje je uključivalo roditelje iz Japana, Tajvana i SAD-a, roditelji vrtićke djece u sve tri kulture zastupali su uvjerenje da su dječaci bolji u matematici, a djevojčice u čitanju (Lummis i Stevenson, 1990).

Iako nalazi istraživanja vezani uz rodne razlike $\mathrm{u}$ roditeljskim socijalizacijskim ponašanjima nisu u potpunosti jednoznačni (Simpkins i sur., 2005), veći broj istraživanja sugerira da rodno stereotipni obrasci razlika postoje i u roditeljskim ponašanjima vezanim uz STEM područje. Primjerice, Jacobs i Bleeker (2004) su utvrdile da majke dječaka u odnosu na majke djevojčica češće svojoj djeci kupuju igračke i knjige povezane s matematikom i to neovisno o djetetovoj dobi. Međutim, majke ženske djece su u istom istraživanju izvijestile o većoj razini uključenosti u matematičke aktivnosti sa svojim kćerima, nego majke dječaka, što može biti posljedica roditeljske percepcije da kćeri trebaju više pomoći u matematici (Jacobs i Bleeker, 2004). Crowley i sur. (2001) su utvrdili da je tri puta veća vjerojatnost da će roditelji koristiti objašnjenja tijekom posjeta izložbama u prirodoslovnim muzejima ako je dijete dječak, nego djevojčica. Ovaj nalaz je utvrđen na uzorku koji je uključivao i vrlo malu djecu između jedne i tri godine, što sugerira da roditelji stvaraju rodno uvjetovane razlike u dječjem učenju prirodoslovnih sadržaja i prije nego se djeca susretnu s formalnim obrazovanjem u ovom području (Crowley i sur., 2001). Eccles i sur. (1993a) su pronašli da roditelji češće potiču dječake na sudjelovanje u matematičkim i prirodoslovnim aktivnostima kod kuće i rad na računalu te da će češće uključiti dijete u aktivnosti građenja i izrade stvari ako je ono muškog roda. Eccles (2015) napominje kako opisane rodno-uvjetovane razlike u roditeljskim uvjerenjima i ponašanjima mogu barem dijelom objasniti rodne razlike u učeničkim motivacijskim uvjerenjima u STEM obrazovnom području.

Imajući u vidu važnost, složenost te specifične probleme STEM obrazovnog područja koji su opisani u uvodu ovog rada, važno je empirijski utvrditi što veći broj čimbenika koji mogu objasniti učeničke obrazovne ishode u ovom području. Iako su roditelji, uz učitelje, 
prepoznati kao krucijalni socijalizacijski čimbenici u STEM području (Chouinard i sur., 2007), roditeljski su utjecaji u ovom području nedovoljno istraženi, a roditelje se rijetko uključuje u programe kojima je cilj promicanje učeničkog interesa za STEM obrazovanje (Rozek, Hyde, Svoboda, Hulleman i Harackiewicz, 2015). Uzimajući u obzir nedostatke prethodnih istraživanja, kao i ranije opisanu važnost heterogene konceptualizacije STEM područja, u ovom smo istraživanju ispitali složeni model roditeljskih odrednica učeničkih obrazovnih ishoda u dva STEM školska područja - matematici i tehničkoj kulturi. Ispitani je model temeljen na teorijskim pretpostavkama i konstruktima iz ranije opisanih modela očekivanja i vrijednosti (Eccles i sur., 1983; Eccles i Wigfield, 2002) i modela roditeljske socijalizacije dječjih obrazovnih ishoda (Eccles, 1993; Simpkins i sur., 2015a). U ispitanom konceptualnom modelu smo integrirali glavne učeničke konstrukte iz modela očekivanja i vrijednosti (učenička motivacijska uvjerenja, odabire aktivnosti i postignuće) te roditeljske konstrukte iz modela roditeljske socijalizacije dječjih obrazovnih ishoda (distalne roditeljske karakteristike, roditeljska uvjerenja i roditeljska ponašanja). I roditeljski i učenički konstrukti operacionalizirani su na način da se odnose usko na matematičko, odnosno tehničko područje obrazovanja. Ovakav pristup nam je omogućio provjeru roditeljske socijalizacije različitih učeničkih obrazovnih ishoda u matematici i tehničkoj kulturi te ispitivanje složenih medijacijskih mehanizama u podlozi roditeljskih učinaka koji uključuju i roditeljske i učeničke posredujuće varijable. 


\section{CILJ, PROBLEMI I HIPOTEZE}

Cilj ovog istraživanja bio je ispitati roditeljske odrednice učeničkih obrazovnih ishoda (motivacijskih uvjerenja, slobodnih aktivnosti te postignuća) u dva STEM školska područja, korištenjem teorijskih pretpostavki i konstrukata specificiranih modelom očekivanja i vrijednosti (Eccles i sur., 1983; Eccles i Wigfield, 2002) te modelom roditeljske socijalizacije dječjih obrazovnih ishoda (Eccles, 1993; Simpkins i sur., 2015a). Istraživanjem će se pokušati odgovoriti na dva šira problema koja su specificirana u nastavku.

\section{1. Prvi istraživački problem}

Prvi problem ovog istraživanja bio je testirati konceptualni model roditeljskih odrednica učeničkih obrazovnih ishoda u STEM područjima matematike i tehničke kulture (Slika 3), odnosno, ispitati izravne i neizravne odnose između distalnih i proksimalnih roditeljskih varijabli i učeničkih obrazovnih ishoda u ova dva područja. Distalne roditeljske varijable se pritom odnose na obrazovni stupanj roditelja, a proksimalne varijable na roditeljska uvjerenja specifična za dijete u matematici i tehničkoj kulturi te roditeljska ponašanja vezana uz matematičko i tehničko područje. Učenički obrazovni ishodi se odnose na učeničko školsko postignuće u matematici i tehničkoj kulturi, učenička motivacijska uvjerenja u ovim predmetima (samoefikasnost i komponente subjektivne vrijednosti zadatka) te učeničko bavljenje izvanškolskim aktivnostima u matematičkom i tehničkom području. 


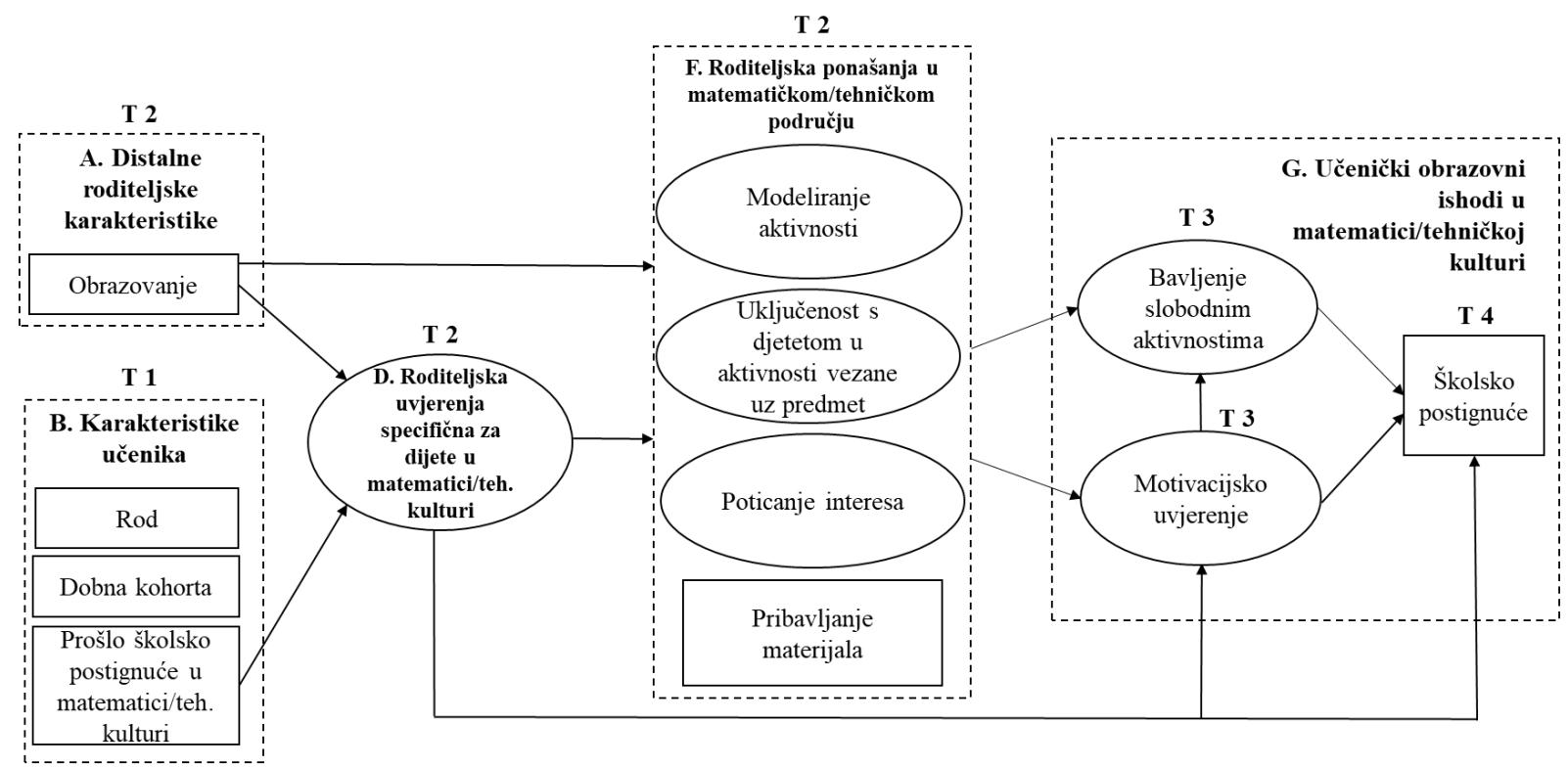

Slika 3. Konceptualni model roditeljskih odrednica učeničkih obrazovnih ishoda u matematici i tehničkoj kulturi i oznake vremenskih točki prikupljanja podataka.

Napomena. Vrijeme prikupljanja podataka: T1: prikupljanje podataka učenika petog i šestog razreda na kraju školske godine; T2: ispitivanje roditelja učenika šestog i sedmog razreda na početku školske godine; T3: ispitivanje učenika šestog i sedmog razreda na polovici školske godine; T4: prikupljanje podataka učenika šestog i sedmog razreda na kraju školske godine.

U konceptualnom modelu na Slici 3, varijable koje su modelirane na latentnoj razini su prikazane elipsom, dok su pravokutnikom prikazane varijable koje su modelirane na manifestnoj razini. Radi jednostavnosti, nisu prikazani pojedini manifestni indikatori za latentne varijable, već su oni opisani u dijelu rada u kojem je dan prikaz korištene metodologije. Model je testiran zasebno za tri specifične vrste motivacijskih uvjerenja učenika. Ta uvjerenja su samoefikasnost u predmetu te dvije komponente subjektivne vrijednosti zadatka komponenta interesa za predmet te komponentna vrijednosti koja je temeljena na združenoj učeničkoj percepciji važnosti i korisnosti predmeta $^{8}$ (engl. importance value; Jacobs i sur., 2002; Simpkins i sur., 2012). Također, svaki od modela zasebno je provjeren u području matematike i u području tehničke kulture. U kontekstu prvog istraživačkog problema, formuliran je niz istraživačkih hipoteza koje su postavljene na temelju teorijskih pretpostavki modela očekivanja i vrijednosti te modela roditeljske socijalizacije dječjih obrazovnih ishoda. Radi preglednosti, hipoteze $(\mathrm{H})$ su podijeljene u četiri šire kategorije s obzirom na pojedine cjeline konceptualnog modela.

\footnotetext{
${ }^{8}$ Do sad korišteni hrvatski prijevod komponenti subjektivne vrijednosti zadatka su (Rovan i sur., 2013): važnost (eng. attainment value), interes ili intrinzična vrijednost (eng. intrinsic value), korisnost (eng. utility value) i cijena truda (eng. cost). Stoga treba naglasiti da se u ovom radu pojam važnost ne odnosi na zasebnu vrijednosnu komponentu (eng. attainment value), nego na kompozit važnosti i korisnosti.
} 
2. 1. 1. Hipoteze u području utjecaja distalnih roditeljskih karakteristika

H (1a): Očekujemo da će viši stupanj obrazovanja roditelja biti izravno povezan s pozitivnijim roditeljskim uvjerenjima specifičnim za dijete u matematici/tehničkoj kulturi (uvjerenja o višoj djetetovoj sposobnosti u predmetu, trudu i interesu za predmet te višoj korisnosti predmeta za dijete) te $\mathrm{s}$ češćim roditeljskim poticanjem interesa i većim pribavljanjem materijala za dijete u ovim područjima.

H (1b): Očekujemo da će viši stupanj obrazovanja roditelja biti neizravno povezan s višom učeničkom samoefikasnosti u matematici/tehničkoj kulturi i višim postignućem u ovim predmetima. Roditeljska uvjerenja će biti medijator odnosa između obrazovanja roditelja i učeničkog postignuća, dok će odnos između obrazovanja roditelja i učeničke samoefikasnosti biti posredovan preko roditeljskih uvjerenja i roditeljskih ponašanja (poticanja interesa i pribavljanje materijala).

T 2

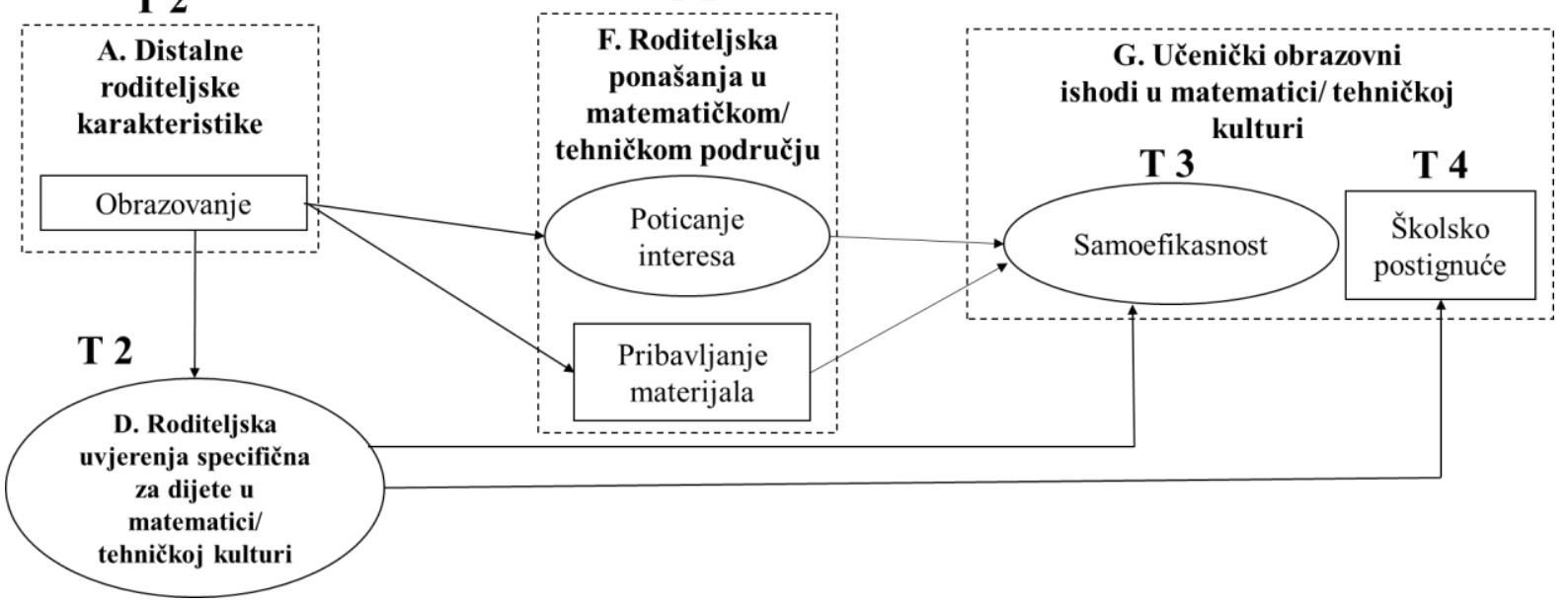

Slika 4. Odnosi među konstruktima u konceptualnom modelu pretpostavljeni hipotezama u području roditeljskih distalnih karakteristika (H1a do H1b).

2. 1. 2. Hipoteze u području utjecaja roditeljskih uvjerenja specifičnih za dijete

H (2a): Polazeći od roditeljske uloge tzv. "tumača stvarnosti" (Eccles, 1993), očekujemo da će roditeljska uvjerenja specifična za dijete u matematici/tehničkoj kulturi djelovati kao djelomični medijator pozitivnog odnosa između prošlog učeničkog postignuća i kasnije učeničke samoefikasnosti u ovim predmetima. 
H (2b): Očekujemo da će pozitivnija roditeljska uvjerenja specifična za dijete u matematici/tehničkoj kulturi predviđati češće roditeljsko poticanje djetetovih interesa i veće pribavljanje materijala za dijete u ovim područjima, ali rjeđu roditeljsku uključenost s djetetom $\mathrm{u}$ aktivnosti vezane uz ove predmete.

H (2c): Očekujemo da će pozitivnija roditeljska uvjerenja specifična za dijete u matematici/tehničkoj kulturi predviđati viša učenička motivacijska uvjerenja i više kasnije postignuće u ovim predmetima te će ti odnosi biti dijelom izravni, a dijelom neizravni. Pobliže, očekujemo da će odnos između roditeljskih uvjerenja i učeničkih motivacijskih uvjerenja biti dijelom posredovan preko roditeljske uključenosti $\mathrm{u}$ aktivnosti $\mathrm{s}$ djetetom vezane $\mathrm{uz}$ matematiku/tehničku kulturu, poticanja interesa te pribavljanja materijala u ovim područjima. Neizravan odnos između roditeljskih uvjerenja i učeničkog kasnijeg postignuća će biti ostvaren tako što će pozitivnija roditeljska uvjerenja predviđati viša učenička motivacijska uvjerenja koja će predviđati više postignuće u matematici/tehničkoj kulturi.

H (2d): Očekujemo da će od svih ispitivanih roditeljskih utjecaja (distalne karakteristike, uvjerenja i ponašanja roditelja), roditeljska uvjerenja specifična za dijete imati najsnažniji i najkonzistentniji učinak u predviđanju učeničkih obrazovnih ishoda $u$ matematici/tehničkoj kulturi.

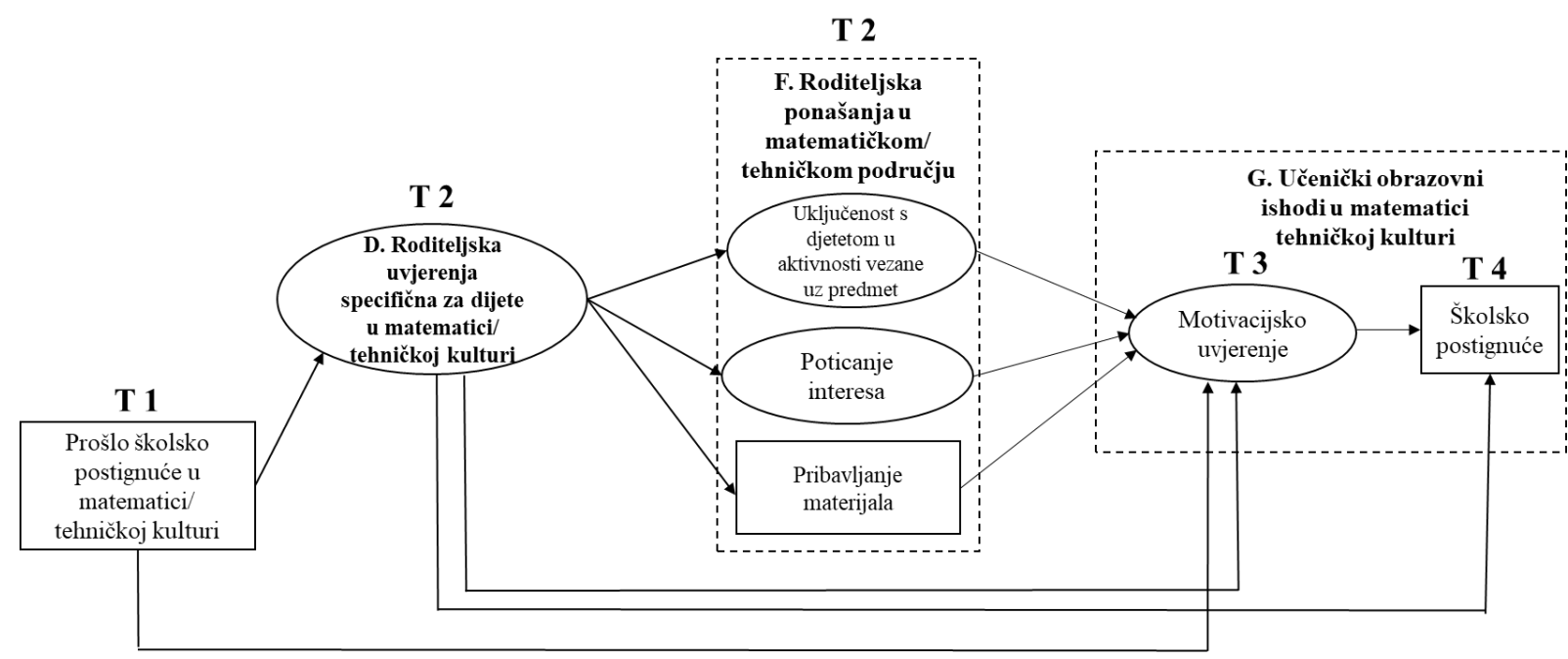

Slika 5. Odnosi među konstruktima u konceptualnom modelu pretpostavljeni hipotezama u području roditeljskih uvjerenja specifičnih za dijete (H2a do $\mathrm{H} 2 \mathrm{c})$.

2. 1. 3. Hipoteze u području utjecaja roditeljskih ponašanja

H (3a): Očekujemo da će izraženija roditeljska ponašanja modeliranja aktivnosti, poticanja interesa te pribavljanja materijala u matematičkom/tehničkom području izravno 
predviđati viša učenička motivacijska uvjerenja u matematici/tehničkoj kulturi i češće učeničko bavljenje slobodnim aktivnostima u ovim područjima, dok će češće roditeljsko ponašanje uključenosti s djetetom u aktivnosti vezane uz matematiku/tehničku kulturu izravno predviđati nižu razinu ovih učeničkih ishoda.

H (3b): Očekujemo da će roditeljska ponašanja predviđati učeničko bavljenje aktivnostima u matematičkom/tehničkom području dijelom i neizravno - preko viših učeničkih motivacijskih uvjerenja u matematici/tehničkoj kulturi koja će predviđati češće učeničko bavljenje aktivnostima u ovim područjima.

H (3c): Očekujemo da će od ispitivanih ponašanja, ona ponašanja koja podrazumijevaju veći stupanj izravne interakcije roditelj-dijete (roditeljska uključenost s djetetom u aktivnosti vezane uz matematiku/tehničku kulturu i roditeljsko poticanje djetetovih interesa u ovim područjima) biti snažniji prediktori učeničkih ishoda nego ona ponašanja koja podrazumijevaju manje izravne interakcije (roditeljsko modeliranje aktivnosti i pribavljanje materijala za dijete u matematičkom/tehničkom području).

T 2

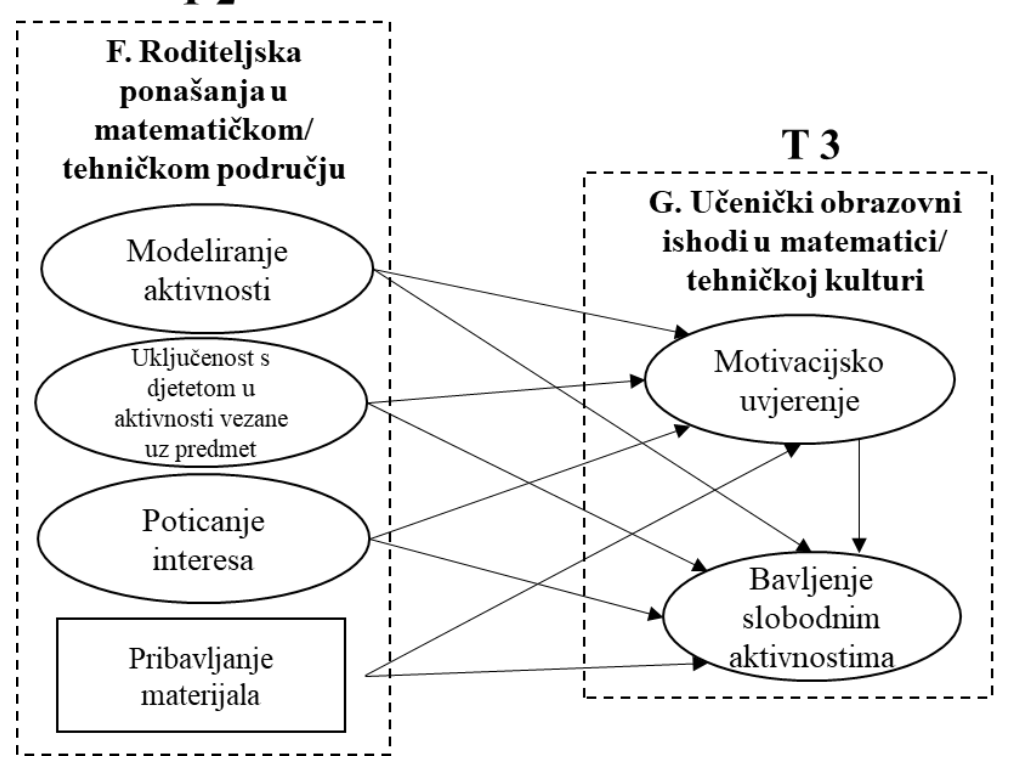

Slika 6. Odnosi među konstruktima u konceptualnom modelu pretpostavljeni hipotezama u području roditeljskih ponašanja (H3a do $\mathrm{H} 3 b)$.

\section{2. Drugi istraživački problem}

Drugi problem ovog istraživanja bio je provjeriti razlikuju li se odnosi pretpostavljeni konceptualnim modelom s obzirom na rod učenika te s obzirom na stupanj obrazovanja roditelja. Za ovaj su problem postavljene sljedeće hipoteze: 
H (4a): Očekujemo da će modelom pretpostavljeni odnosi u jednakoj mjeri vrijediti za djevojčice i dječake.

H (4b): Očekujemo da će kod roditelja višeg obrazovanja prethodno postignuće njihove djece u matematici/tehničkoj kulturi biti snažnije povezano s roditeljskim uvjerenjima specifičnim za dijete u ovim predmetima nego kod roditelja nižeg obrazovanja.

H (4c): Očekujemo da će kod roditelja višeg obrazovanja njihova uvjerenja specifična za dijete u matematici/tehničkoj kulturi biti snažnije povezana s njihovim ponašanjima u ovim područjima nego kod roditelja nižeg obrazovanja. 


\section{METODA}

\section{1. Sudionici i uzorkovanje}

Podaci koji su korišteni u ovom radu prikupljeni su u sklopu JOBSTEM ${ }^{9}$ istraživačkog projekta kojeg je financirala Hrvatska zaklada za znanost, a ustanova nositeljica projekta bio je Institut društvenih znanosti Ivo Pilar u Zagrebu. U projektnom istraživanju su kroz tri vala praćeni učenici tri dobne kohorte, iz ukupno 16 osnovnih škola sa sjeverozapada Hrvatske (grad Zagreb i okolica). Budući da se u prošlom istraživanju (Babarović, Burušić i Šakić, 2009) pokazalo da je stupanj urbanizacije i razvijenosti okoline u kojoj se škola nalazi važna odrednica školskog postignuća učenika, u uzorku su podjednako bile zastupljene škole iz različito urbaniziranih sredina. Po četiri škole su pripadale jednom od četiri klastera koji su se razlikovali s obzirom na stupanj urbanizacije matičnih općina. Jedinice uzorkovanja su bila razredna odjeljenja učenika unutar jedne dobne kohorte. Planirana veličina jedne kohorte je bila 640 učenika. Imajući u vidu da prosječno razredno odjeljenje u hrvatskim osnovnim školama ima 20 učenika (Babarović, Burušić i Šakić, 2013), procijenjeno je da je potrebno uzrokovati oko 32 razredna odjeljenja u svakoj dobnoj kohorti kako bi se postigla planirana veličina uzorka. Stoga su u svakoj od 16 škola slučajno uzorkovana po dva razredna odjeljenja unutar jedne dobne kohorte.

U ovom su doktorskom istraživanju korišteni podaci učenika šestog i sedmog razreda osnovne škole koji su prikupljeni u drugom valu projektnog istraživanja. U ovom su valu obuhvaćena 32 šesta te 32 sedma razreda - ukupno 1454 učenika. Od tog su broja u drugom valu istraživanja naposljetku sudjelovala 1192 učenika (82 \%), a roditeljski podaci su prikupljeni za ukupno 1174 učenika (80.7 \%). Za svakog smo učenika istraživanjem obuhvatili jednog od njegovih roditelja, bez ograničenja treba li u istraživanju sudjelovati otac ili majka. Za četiri učenika roditeljski podaci su tretirani kao nedostajući. Naime, u tri slučaja roditeljski upitnik nije ispunio roditelj ili skrbnik, već su dva puta to bili odgojitelji, a jednom djed. Jedan je roditelj naznačio da je upitnik ispunjavao zajedno s djetetom. Stoga je valjan uzorak uključivao 1170 roditelja/skrbnika. Međutim, u konačan uzorak za ovo istraživanje su uključeni samo oni učenici za koje su prikupljeni i roditeljski podaci, odnosno, samo oni roditelji za koje

\footnotetext{
${ }^{9}$ Puni naziv projekta glasi "Profesionalne aspiracije prema STEM zanimanjima tijekom osnovne škole: Longitudinalno istraživanje odnosa postignuća, vjerovanja o vlastitim sposobnostima i interesa za zanimanja" (voditelj: prof. dr. sc. Josip Burušić). Projekt se provodio u razdoblju od 1.9.2015. do 31.8.2019. te ga je u potpunosti financirala Hrvatska zaklada za znanost (IP-09-2014-9250).
} 
smo imali učeničke podatke. Od 1192 učenika, koliko je sudjelovalo u drugom valu istraživanja, za 1064 učenika smo prikupili podatke njihovih roditelja (89.3 \%). Stoga je konačan uzorak u ovom istraživanju uključivao 1064 učenika te 1064 roditelja. U većini škola (ukupno devet od 16 škola) odaziv roditelja za sudjelovanje u istraživanju je bio veći od 90 \%. U četiri škole je odaziv roditelja bio veći od $80 \%$, a u preostale tri je bio veći od $70 \%$. U konačnom učeničkom uzorku bilo je otprilike podjednako djevojčica $(N=511 ; 48 \%)$ i dječaka $(N=553 ; 52 \%)$ te podjednako učenika šestog $(N=521 ; 49 \%)$ i sedmog razreda $(N=543 ; 51 \%)$. Većinu roditeljskog uzorka činile su majke ili skrbnice. Roditeljski upitnik ispunilo je 813 majki/skrbnica (76.4\%) te 203 oca/skrbnika (19.1\%), dok za 48 roditelja (4.5\%) nedostaje podatak o rodu.

Među učenicima šestih razreda bilo je otprilike podjednako djevojčica $(N=252 ; 48.4$ $\%)$ i dječaka $(N=269 ; 51.6 \%)$, a roditeljski upitnik je ispunilo 400 majki/skrbnica $(76.8 \%)$ te 95 očeva/skrbnika (18.2\%), dok za 26 roditelja (5\%) nedostaje podatak o rodu. Među učenicima sedmih razreda također je bilo otprilike podjednako djevojčica $(N=259 ; 47.7 \%)$ i dječaka $(N=284 ; 52.3 \%)$, a roditeljski upitnik je ispunilo 411 majki/skrbnica (75.7 \%) te 108 očeva/skrbnika (19.9\%), dok za 24 roditelja (4.4\%) nedostaje podatak o rodu.

\section{2. Instrumenti}

Imajući u vidu preuzeti teorijski okvir, operacionalizacije konstrukata u ovom istraživanju većim dijelom slijede empirijske radove Eccles i suradnika te je u skladu s time većina mjernih skala preuzeta iz projekta "Childhood and Beyond Study (CAB)" (Eccles, Wigfield i Blumenfeld, 1984). Sve opisane mjere konstrukata su osmislili, prilagodili i dopunili istraživači unutar JOBSTEM istraživačkog projekta tako da se one odnose na sadržaje STEM obrazovnog područja, dok su za potrebe ovog istraživanja korištene mjere koje se odnose na matematičko i tehničko područje. Treba napomenuti da su mjere razvijene unutar CAB projekta vrlo kratke pa se tako za mjerenje jednog konstrukta najčešće koristi tek nekoliko čestica. Međutim, do sad se pokazalo da ove mjere imaju vrlo dobre psihometrijske karakteristike (npr. Eccles, Freedman-Doan, Frome, Jacobs i Yoon, 2000; Fredricks i Eccles, 2005; Jacobs i sur., 2002; Simpkins i sur., 2015b). Relativno mali broj čestica opravdan je i s obzirom da je u ovom istraživanju kao glavna analitička metoda korišteno strukturalno modeliranje (SEM) ${ }^{10}$. Naime, istraživanja sugeriraju da je unutar SEM analiza najbolje koristiti manji broj manifestnih

\footnotetext{
${ }^{10}$ Radi jezične jednostavnosti, u daljnjem ćemo se tekstu pri referiranju na analitičke postupke u okviru modeliranja strukturalnim jednadžbama koristiti skraćenicom "SEM".
} 
indikatora koji dobro reprezentiraju latentni konstrukt (Hayduk i Littvay, 2012). Također je poznato da je unutar SEM analiza veliki broj indikatora nerijetko povezan s praktičnim problemima pristajanja modela podacima (Kelloway, 1998).

U ovom su se istraživanju pojedine mjere eksplicitno odnosile na matematiku i tehničku kulturu kao STEM nastavne predmete, dok su određene mjere bile vezane uz matematičko i tehničko područje aktivnosti. Ova distinkcija između nastavnog predmeta i šireg područja aktivnosti se ne pojavljuje u elaboraciji modela Eccles i suradnika (npr. Eccles, 1993). Stoga je u ovom istraživanju preuzet metodološki pristup koji se do sad koristio u većem broju radova u području. Naime, pregledom empirijskih radova u STEM području obrazovanja koji su temeljeni na modelima Eccles i suradnika, vidljivo je da se procjene učeničkih motivacijskih uvjerenja te procjene roditeljskih uvjerenja specifičnih za dijete većinom usko vežu uz nastavne predmete, najčešće matematiku ili prirodoslovlje (npr. Bhanot i Jovanovic, 2009; Gniewosz i Watt, 2017; Simpkins, Estrella, Gaskin i Kloberdanz, 2018; Taskinen i sur., 2016). S druge strane, kada govorimo o mjerama roditeljskih ponašanja, dosadašnja su istraživanja koristila skale koje su se najčešće odnosile na roditeljska ponašanja u širem području matematičkih, prirodoslovnih ili računalnih aktivnosti i interesa (npr. Bhanot i Jovanovic, 2009; Jacobs i Bleeker; 2004; Simpkins i sur., 2005; Simpkins i sur., 2012). Sljedeći ovu metodologiju, u ovom su istraživanju roditeljska uvjerenja specifična za dijete te učenička motivacijskih uvjerenja operacionalizirana tako da se odnose na matematiku i tehničku kulturu kao nastavne predmete. S druge strane, mjere roditeljskih ponašanja su operacionalizirane tako da se odnose na šire matematičko i tehničko područje, osim mjere roditeljske uključenosti koja je usmjerena na roditeljsku participaciju s djetetom u aktivnostima vezanim uz nastavne predmete matematike i tehničke kulture.

Naposljetku, kada govorimo o učeničkim ponašajnim varijablama, modeli Eccles i suradnika pod ovim konstruktima prvenstveno podrazumijevaju odabire aktivnosti (Wigfield i sur., 2015). U užem obrazovnom smislu, ti se odabiri odnose na izbor nastavnih predmeta STEM područja (npr. Dickhäuser i Stiensmeier-Pelster, 2003; Simpkins i sur., 2006) ili izbor srednje škole ili fakulteta u STEM području (npr. Lykkegaard i Ulriksen, 2016). S obzirom da u hrvatskim osnovnim školama učenici ne mogu birati predmet ili razinu zahtjevnosti predmeta u matematičkom i tehničkom području, ovakve mjere nisu mogle biti korištene u ovom istraživanju. Također, učenici u ispitivanim dobnim kohortama još nisu suočeni s odabirom nastavka školovanja. Međutim, kao što je već bilo riječi u uvodu ovog rada, unutar modela Eccels i suradnika kao mjera učeničkih ponašanja u osnovnoj školi do sad se koristila i procjena uključenosti učenika u različite izvanškolske aktivnosti koje su povezane sa STEM područjima 
(npr. Simpkins i sur., 2005; Simpkins i sur., 2006). Po uzoru na ove empirijske radove, i u ovom je istraživanju kao mjera učeničkih ponašanja korištena učenička procjena uključenosti u različite aktivnosti koje se odnose na matematičko i tehničko područje.

U nastavku ovog poglavlja korištene mjere su kategorizirane s obzirom na šire konstrukte koji su specificirani u konceptualnom modelu prikazanom na Slici 3. Za mjere koje uključuju više od jedne čestice su također prikazani koeficijenti pouzdanosti tipa unutarnje konzistencije (Cronbachov alpha).

\section{2. 1. Distalne roditeljske karakteristike}

Podatak o obrazovanju roditelja preuzet je iz šireg roditeljskog upitnika konstruiranog za potrebe JOBSTEM projekta. Roditelji su trebali naznačiti najvišu razinu svog obrazovanja na skali od 6 stupnjeva ( 1 = „nezavršena ili završena osnovna škola“, 2 = „završena srednja strukovna škola“, 3 = „završena gimnazija“, 4 = ,završena viša škola“, 5 = ,završen fakultet“, $6=$,stečen magisterij ili doktorat znanosti“"). Ova je varijabla u model unesena kao opažena varijabla.

\section{2. 2. Roditeljska uvjerenja specifična za dijete u matematici i tehničkoj kulturi}

Roditeljska uvjerenja su u strukturalnom modelu modelirana kao latentni konstrukt s četiri indikatora u slučaju oba predmeta. Ti su indikatori bili roditeljska percepcija djetetove sposobnosti za nastavni predmet, roditeljska percepcija korisnosti predmeta za dijete, roditeljska percepcija djetetovog interesa za predmet te roditeljska percepcija djetetovog truda u predmetu. Prva dva indikatora su izražena kao prosjek čestica, dok druga dva indikatora čini po jedna čestica. Mjere svih indikatora su preuzete iz CAB projekta te se u prošlim istraživanjima pokazalo da imaju odlične psihometrijske karakteristike, uključujući dobru pojavnu, diskriminativnu i prediktivnu valjanost (npr. Eccles i sur., 2000; Fredricks i Eccles, 2005).

Roditeljska percepcija djetetove sposobnosti $u$ predmetu je mjerena s po četiri čestice za svaki nastavni predmet: 1) „Djeca mogu biti različito uspješna u pojedinim školskim predmetima. Što Vi mislite, koliko je Vaše dijete uspješno u (predmet)?“ (1 = „uopće nije uspješno“, 7 = ,,jako je uspješno“); 2) „Što mislite, koliko je Vašem djetetu (predmet) težak? “ $(1=$, jako mu je lagan“, 7 = ,jako mu je težak“ $) ; 3)$ „U usporedbi s ostalom djecom, što mislite, koliko je Vaše dijete uspješno u (predmet)?“ (1 = „puno je lošije“, 7 = „puno je bolje“); te 4) 
„U usporedbi s ostalom djecom, što mislite, koliko Vaše dijete ima urođenih sposobnosti ili talenta za (predmet)?“ (1 = ,puno manje“, 7 = ,puno više“). Rezultat na drugoj čestici je rekodiran u suprotnom smjeru kako bi veći rezultat odražavao roditeljsku procjenu o višim djetetovim sposobnostima u nastavnom predmetu. Cronbachov alpha za ove četiri čestice iznosi $.91 \mathrm{u}$ području matematike te .82 u području tehničke kulture.

Roditeljska percepcija korisnosti predmeta za dijete mjerena je s po dvije čestice za svaki predmet: 1) „Što mislite, koliko je (predmet) Vašem djetetu koristan za budućnost?" (1 = „uopće nije koristan“, 7 = ,jako je koristan“); te 2) „Što mislite, koliko će Vašem djetetu u budućem zanimanju koristiti znanja iz (predmet)?" (1 = „uopće mu neće koristiti“, 7 = ,jako će mu koristiti“). Cronbachov alpha za ove dvije čestice iznosi .85 za roditeljsku procjenu u području matematike te .85 za procjenu u području tehničke kulture.

Roditeljska percepcija djetetovog interesa za predmet te roditeljska percepcija djetetovog truda mjerene su obje s po jednom česticom za svaki predmet. Kao mjera roditeljske percepcije interesa korištena je čestica „Koliko Vaše dijete pokazuje interesa za (predmet)?“ (1 $=$ „,uopće ne pokazuje“, 7 = ,jako puno interesa“), a kao mjera percepcije djetetovog truda u predmetu čestica: „Koliko se Vaše dijete trudi oko (predmet)?“ $(1$ = „uopće se ne trudi“, 7 = ,jako se trudi“').

\section{2. 3. Roditeljska ponašanja u području matematike i tehničke kulture}

Roditeljska ponašanja modeliranja aktivnosti u matematičkom/tehničkom području, poticanja djetetovog interesa za matematičko/tehničko područje i uključenosti u djetetove aktivnosti vezane uz matematiku/tehničku kulturu modelirana su kao zasebne latentne varijable s pojedinačnim česticama kao manifestnim indikatorima. Roditeljsko pribavljanje materijala u STEM području uneseno je model kao opažena varijabla. Čestice za mjeru konstrukata roditeljskog modeliranja te poticanja djetetovih interesa osmišljene su i prilagođene $u$ okviru JOBSTEM istraživačkog projekta, po uzoru na čestice korištene u projektima CAB (Eccles i sur., 1984) i ASPIRES (Archer i sur., 2013). Čestice za mjeru roditeljskog pribavljanja STEM materijala dijelom su preuzete i adaptirane iz CAB projekta (Eccles i sur., 1982) te nadopunjene novim česticama za potrebe JOBSTEM projekta.

$\mathrm{Za}$ latentni konstrukt roditeljskog modeliranja aktivnosti u području matematike korištena su dva indikatora, a za modeliranje aktivnosti u području tehničke kulture tri indikatora. Kao indikatori u području matematike korištene su roditeljske procjene o tome koliko često „sami kod kuće ili u slobodno vrijeme, rješavaju matematičke zagonetke, zadatke 
ili slagalice“ te „rješavaju zagonetke, mozgalice, pitalice“. U području tehničkih aktivnosti, roditelji su trebali naznačiti koliko često ,izrađuju makete i modele stvari“ ${ }^{\prime \prime}$, slažu Lego kocke ili puzzle" te ,izrađuju ili popravljaju stvari korištenjem raznih alata“. U oba slučaja, skala odgovora je imala šest stupnjeva ( $1=$,nikada“, $6=$,vrlo često“"). Roditeljima je u uputi naglašeno da naznače koliko navedene aktivnosti provode sami, kako bi se dobila mjera „pravog“ modeliranja koje po definiciji ne uključuje interakciju s djetetom (Simpkins i sur., 2005). Treba napomenuti da iako ovaj faktor u slučaju matematike ima samo dva indikatora, taj se broj smatra dovoljnim u više-faktorskim strukturalnim modelima (Kline, 2015), kao što su modeli koji su testirani $\mathrm{u}$ ovom istraživanju. Cronbachov alpha za čestice $\mathrm{u}$ području modeliranja matematičkih aktivnosti iznosi .76, a za čestice u području tehničkih aktivnosti .63.

Roditeljska uključenost $\mathrm{s}$ djetetom u aktivnosti povezane s predmetom je mjerena s po tri indikatora za svaki predmet. Roditelji su za svaki predmet trebali procijeniti koliko često: 1) „razgovaraju s djetetom o onome što uči na satovima iz (predmeta)“; 2) „pomažu djetetu oko domaćih zadaća iz (predmeta)“; te 3), „pomažu djetetu u učenju za testove $i$ ispitivanja iz (predmeta)“ $(1=$ „vrlo rijetko“, $5=$ „vrlo često“). Ove čestice preuzete su iz šireg upitnika roditeljske uključenosti (Walker, Wilkins, Dallaire, Sandler i Hoover-Dempsey, 2005). Cronbachov alpha za ove čestice iznosi .83 u oba područja.

Roditeljsko poticanje djetetovih interesa u području matematike mjereno je s tri indikatora, a u području tehničke kulture s četiri. Primjer čestice za matematiku je: „Koliko često potičete dijete da igra igre u kojima se koristi matematika?". Primjer čestice u području tehničke kulture je: „Koliko često potičete dijete da izrađuje makete i modele stvari?“. Skala odgovora za oba predmeta je od $1=$,vrlo rijetko“ do $5=$ „vrlo često“. Cronbachov alpha za čestice poticanja iznosi $.70 \mathrm{u}$ oba područja.

Roditeljsko pribavljanje materijala mjereno je česticama Skale pribavljanja STEM materijala koja je formirana za potrebe JOBSTEM projekta te se sastoji se od ukupno 13 dihotomnih čestica koje opisuju određenu opremu, igračke ili materijale vezane uz STEM područje. Zadatak roditelja bio je naznačiti što od nabrojane opreme, materijala ili igračaka njihovo dijete ima u svom domu za korištenje $(0=n e ; 1=\mathrm{da})$. Ova skala je za potrebe projekta formirana za cjelovito STEM područje, a ne za izdvojene nastavne predmete STEM područja. Zbog toga za potrebe ovog istraživanja nije bilo moguće izdvojiti dovoljan broj čestica koje bi se odnosile na materijale koji su vezani isključivo uz matematiku i isključivo uz tehničku kulturu. Stoga su u ovom istraživanju korištene sve čestice na ovoj skali, osim čestica koje su se odnosile isključivo na područje prirodoslovlja, a kojih je bilo ukupno šest. Primjer takve čestice koja nije korištena u ovom istraživanju je ,dječji set za pokuse iz kemije, fizike ili 
biologije“. Tako je roditeljsko pribavljanje STEM materijala u ovom istraživanju bilo mjereno s ukupno sedam čestica te je isti latentni konstrukt bio korišten i u strukturalnim modelima za matematiku i u strukturalnim modelima za tehničku kulturu. Primjeri korištenih čestica su: „računalni software iz matematike, kao što je GeoGebra ili Sketchpad“ te „časopisi ili knjige povezani s tehničkim predmetima (tehničkom kulturom ili informatikom) koje nisu redovni školski udžbenici“‘. Cronbachov alpha za ovih sedam čestica iznosi .66. Za potrebe daljnjih analiza rezultati na ovim česticama su zbrojeni te je ova varijabla u modele unesena kao opažena kontinuirana varijabla.

\section{2. 4. Učenička motivacijska uvjerenja u matematici i tehničkoj kulturi}

Među učeničkim motivacijskim uvjerenjima ispitana je učenička samoefikasnost u predmetu te tri komponente učeničke subjektivne vrijednosti zadatka u predmetu (interes za predmet, korisnost predmeta i važnost uspjeha u predmetu). Mjere ovih učeničkih uvjerenja osmišljene su unutar JOBSTEM projekta po uzoru na mjere korištene u CAB projektu (Eccles i sur., 1984). Prethodna su istraživanja pokazala da ove mjere imaju odlične psihometrijske karakteristike (npr. Jacobs i sur., 2002). Sve učeničke motivacijske varijable modelirane su kao latentni konstrukti u SEM modelima, s pojedinačnim česticama kao manifestnim indikatorima.

Učenička samoefikasnost u predmetu mjerena je s po pet indikatora za svaki predmet. Primjer čestice (indikatora) je: „Kada trebaš naučiti nešto novo iz (predmet) kako ti to ide?" (1 $=$,mislim da mi ide jako loše“, $7=$,mislim da mi ide jako dobro“). Cronbachov alpha za ove čestice u području matematike iznosi .95 , a u području tehničke kulture .93 .

Izmjerene su tri komponente učeničke subjektivne vrijednosti zadatka u predmetu: interes za predmet (četiri čestice po predmetu), korisnost predmeta (dvije čestice po predmetu) te važnost uspjeha u predmetu (dvije čestice po predmetu). Primjer čestice za interes je: „U usporedbi s ostalim školskim predmetima, koliko ti se (predmet) sviđa?“ (1 = „ne sviđa mi se toliko koliko mi se sviđaju drugi predmeti““, 7 = „,sviđa mi se puno više od drugih predmeta“). Primjer čestice za korisnost je: „Općenito, što misliš koliko je korisno ono što učiš u (predmet)?“ ( 1 = „nije korisno kao ono što učim na drugim predmetima“, $7=$ „,puno je korisnije od onoga što učim na drugim predmetima“). Primjer čestice za važnost uspjeha je: „Općenito, koliko ti je važno biti dobar u (predmet)?“ (1 = „nije mi uopće važno“, 7 = ,jako mi je važno“). Kao što smo prethodno napomenuli, slijedeći prijašnja istraživanja, mjere korisnosti i važnosti su kombinirane u jednu mjeru na koju se u daljnjem tekstu referiramo koristeći pojam "važnost". 
Cronbachov alpha za mjeru interesa za matematiku i tehničku kulturu iznosi 90 i .92, dok za kompozitnu mjeru važnosti iznosi .81 u području matematike te .88 u području tehničke kulture.

\section{2. 5. Učeničke slobodne aktivnosti u matematičkom i tehničkom području}

Čestina učeničkih slobodnih aktivnosti modelirana je kao latentni konstrukt $\mathrm{s}$ pojedinačnim česticama kao indikatorima u SEM modelu. Čestina učeničkih slobodnih aktivnosti koje se odnose na matematičke sadržaje procijenjena je s tri indikatora, a čestina aktivnosti koje uključuju sadržaje vezane uz tehničku kulturu s četiri indikatora. Primjer čestice za matematiku je „Koliko često u svoje slobodno vrijeme igraš igre u kojima se koristi matematika? “, a za tehničko područje: „,Koliko često u svoje slobodno vrijeme izrađuješ makete i modele stvari? “ ( 1 = „nikad“, 5 = ,jako često“). Ove mjere su osmišljene u okviru JOBSTEM istraživačkog projekta po uzoru na čestice korištene u projektima CAB (Eccles i sur., 1984) i ASPIRES (Archer i sur., 2013). Cronbachov alpha za mjeru slobodnih aktivnosti u matematičkom području iznosi .74, a za mjeru aktivnosti u tehničkom području .71.

\section{2. 6. Učeničko školsko postignuće u matematici i tehničkoj kulturi}

Kao kriterijske mjere učeničkog školskog postignuća iz matematike i tehničke kulture korištene su zaključne ocjene iz ovih predmeta u školskoj godinu u kojoj su prikupljene motivacijske i ponašajne mjere učenika, na kraju šestog, odnosno, sedmog razreda. Varijabla učeničkog postignuća u modele je unesena kao opažena varijabla.

\section{2. 7. Kontrolne učeničke varijable}

Kao kategorijalne binarne varijable u modelima su korištene varijable roda učenika $($ dječaci $=0$; djevojčice $=1)$ te dobne kohorte učenika $(0=$ šesti razred; $1=$ sedmi razred $)$. Također je prikupljen podatak o učeničkom postignuću (zaključnoj ocjeni) iz matematike i tehničke kulture na kraju školske godine koja je prethodila dijelu istraživanja u kojem su prikupljeni podaci o učeničkim motivacijskim i ponašajnim varijablama. Riječ je, dakle, o zaključnim ocjenama iz matematike i tehničke kulture na kraju petog, odnosno, šestog razreda. 
Rod učenika, dobna kohorta i prethodna ocjena iz predmeta su u modelima korištene u svojstvu opaženih, kontrolnih varijabli ${ }^{11}$.

\section{3. Postupak}

Prije provedbe istraživanja, unutar JOBSTEM projekta su osigurane dozvole Ministarstva znanosti i obrazovanja, Agencije za odgoj i obrazovanje, odobrenja ravnatelja uključenih škola te pisane suglasnosti roditelja za sudjelovanje njihove djece u projektnim aktivnostima. Šire projektno istraživanje je odobreno od strane Etičkog povjerenstva Instituta društvenih znanosti Ivo Pilar u Zagrebu, dok je doktorsko istraživanje odobreno i od strane Etičkog povjerenstva Odsjeka za psihologiju Filozofskog fakulteta. Istraživanje je provedeno u skladu s Etičkim kodeksom istraživanja s djecom. U istraživanju nije bila prikrivana svrha istraživanja, a roditelji i djeca su bili obaviješteni o svim elementima istraživanja kao i o slobodi uskrate pristanka na sudjelovanje u svakom trenutku istraživanja.

$\mathrm{S}$ obzirom da su podaci za ovo istraživanje prikupljeni u sklopu longitudinalnog istraživačkog projekta, nije bilo moguće organizirati prikupljanje podataka na anoniman način. Prikupljeni osobni podaci učenika (ime i prezime, škola i razredno odjeljenje) korišteni su isključivo u tehničku svrhu sparivanja podataka iz tri vala projektnog istraživanja. Povjerljivost podataka zajamčena je s obzirom da su osobne informacije iz upitnika zamijenjene jedinstvenim identifikacijskim brojem pri unosu podataka u bazu. Povjerljivost je zajamčena i činjenicom da su uvid u upitnike imali samo istraživači, dok škole, nastavnici ili bilo tko drugi ni na koji način nije imao uvid u odgovore učenika ili roditelja. Učenici i roditelji su uputom (roditelji pisanom, učenici usmenom, direktno od istraživača) bili obaviješteni da će u kasnijoj fazi obrade podataka njihovi osobni podaci biti zamijenjeni jedinstvenim identifikacijskim brojem, da su njihovi podaci strogo povjerljivi i poznati samo istraživačima te da će uvijek biti obrađivani i prikazivani samo na grupnoj razini.

\section{3. 1. Istraživanje na uzorku učenika}

Drugi val projektnog istraživanja na uzorku učenika, unutar kojeg su prikupljeni i podaci korišteni u ovom istraživanju, organiziran je grupno u formi papir-olovka. Istraživanje je organizirano za vrijeme redovne nastave, u razrednim odjeljenjima učenika, u trajanju od dva

\footnotetext{
${ }^{11}$ Varijabla prethodnog školskog postignuća iz predmeta (na kraju petog, tj. šestog razreda) je još korištena i kao prediktorska varijabla pri testiranju hipoteze o roditeljskoj ulozi "tumača stvarnosti" (Hipoteza 2a).
} 
školska sata uz pauzu od 5 do 10 minuta za vrijeme školskog odmora. U Tablici 1 prikazane su vremenske točke u kojima su prikupljene pojedine istraživačke varijable. Mjere učeničkih motivacijskih uvjerenja u matematici i tehničkoj kulturi te mjera učeničkog bavljenja slobodnim aktivnostima u ovim područjima prikupljeni su kada su učenici polazili šesti, odnosno sedmi razred, otprilike na sredini školske godine. Unutar JOBSTEM projekta su konstruirane zasebne verzije upitnika za učenike i učenice koje su se razlikovale u jezičnim nastavcima za muški i ženski rod. Svi su upitnici bili obilježeni kodovima s obzirom na razred ${ }^{12}$ i rodnu verziju (npr. kod $6 z ̌$ je ukazivao na upitnik za učenice šestih razreda). Svako ispitivanje učenika vodila su minimalno dva obučena istraživača od kojih bi jedan učenicima pročitao uputu te naglasio da je sudjelovanje $\mathrm{u}$ istraživanju dobrovoljno te da od njega mogu odustati $\mathrm{u}$ bilo kojem trenutku, bez ikakvih posljedica. U uputi je također navedena svrha istraživanja te je jamčena povjerljivost podataka. Istraživači su tijekom ispitivanja odgovarali na eventualne nejasnoće koje su učenici imali.

Tablica 1. Prikaz vremenskih točaka u kojima su prikupljeni podaci o istraživačkim varijablama

\section{$\begin{array}{llll}\text { T1 } & \text { T2 } & \text { T3 } & \text { T4 }\end{array}$}

Učeničke varijable

Motivacijska uvjerenja u mat./teh. kulturi

$\times$

Bavljenje izvanškolskim aktivnostima u mat./teh.

području

Postignuće iz mat./teh. kulture - kriterijska mjera

$\times$

Postignuće iz mat./teh. kulture - kontrolna mjera $\quad \times$

Rod $\quad x$

Dobna kohorta $\quad x$

Roditeljske varijable

$\times$

Napomena. T1: kraj petog/šestog razreda; T2: početak šestog/sedmog razreda; T3: sredina šestog/sedmog razreda; T4: kraj šestog/sedmog razreda.

Kriterijske i kontrolne ocjene učenika iz matematike i tehničke kulture prikupljene su u suradnji sa školskim projektnim koordinatorima kroz e-Matice - centralizirani sustav Ministarstva znanosti i obrazovanja. Riječ je o sustavu u koji se upisuju podaci koji su važni za

${ }^{12}$ Ovakvo označavanje projektnih upitnika je bilo potrebno budući da su upitnici za učenike sedmih razreda sadržavali i pitanja koja su se odnosila na predmete kemije i fizike koji se ne slušaju u šestom razredu. 
praćenje učenika od upisa osnovne škole do završetka osnovnog ili srednjeg obrazovanja. Ovaj sustav omogućuje vjerodostojan i cjelovit uvid u učenikove podatke tijekom njegova obrazovanja (MZO, 2017b).

\section{3. 2. Istraživanje na uzorku roditelja}

Postupak istraživanja na uzorku roditelja uključivao je nekoliko koraka. Prije provedbe istraživanja školama je poslan službeni dopis u kojem je opisan postupak ispitivanja roditelja. Školama su također dostavljene detaljne pisane upute za školske projektne koordinatore kojih se trebalo pridržavati pri organizaciji ispitivanja (Prilog 1). Školama su također dostavljeni upitnici za roditelje zajedno s omotnicama, evidencijske liste učenika koji su sudjelovali u projektu, upute za razrednike uključenih razrednih odjeljenja te podsjetnici za roditelje. Razrednici uključenih razrednih odjeljenja su upitnike zaprimili od školskih koordinatora te su ih raspodijelili učenicima koji su sudjelovali u istraživanju tako da je svaki učenik primio jedan upitnik za roditelja. Upitnik je trebao ispuniti samo jedan/roditelj skrbnik učenika te nije bilo ograničeno treba li to biti majka ili otac, već su roditelji sami mogli odlučiti tko će ispuniti upitnik. Razrednici su učenicima usmeno dali upute o svrsi upitnika za roditelje i postupku vraćanja upitnika u školu.

Kao i u slučaju upitnika za učenike, i u upitnicima za roditelje su postojale određene sadržajne razlike ovisno o dobnoj kohorti učenika (npr. roditelji učenika sedmih razreda su odgovarali na dodatna pitanja koja su se odnosila na nastavne predmete fizike i kemije). Pisanom uputom na početku upitnika roditelji su bili upućeni da popunjeni upitnik, u zatvorenoj omotnici, vrate u školu po svom djetetu. Roditelji su uputom također bili obaviješteni da će omotnicu s upitnikom smjeti otvoriti tek istraživači nakon preuzimanja upitnika iz škole. U uputama za koordinatore i razrednike je bilo naznačeno da cjelokupni proces prikupljanja roditeljskih upitnika ne bi trebao premašiti vremenski period od ukupno sedam dana. Roditeljima koji upitnik ne bi vratili u roku od tri dana po učeniku bi bio poslan kratak pisani podsjetnik o vraćanju upitnika. Nakon zaprimanja svih upitnika, razrednici su upitnike uručili školskim koordinatorima, od kojih su upitnike naposljetku preuzeli članovi istraživačkog tima. Roditeljski podaci prikupljeni su prije učeničkih podataka, pri početku školske godine u kojoj je provedeno ispitivanje učenika. Razmak između prikupljanja roditeljskih i učeničkih podataka bio je između tri i četiri mjeseca. 


\section{4. Statistička obrada podataka}

Prije provedbe središnjih analitičkih postupaka kojima se pokušalo odgovoriti na postavljene istraživačke probleme, najprije su provedene preliminarne analize koje su uključivale: kontrolu unosa podataka ${ }^{13}$, analizu nedostajućih vrijednosti, provjeru statističkih preduvjeta za SEM analizu, izračun osnovnih deskriptivnih parametara učeničkih i roditeljskih varijabli te izračun Pearsonovih korelacija između svih učeničkih i roditeljskih varijabli. Ove su analize provedene pomoću IBM SPSS statističkoga paketa (verzija 20.0).

Kao osnovni analitički postupak kojim se pokušalo odgovoriti na istraživačke probleme u ovom je istraživanju korišteno modeliranje strukturalnim jednadžbama (engl. structural equation modeling - SEM). Sve analize u okviru SEM metodologije su provedene u statističkom programu R i pripadajućem paketu Latent Variable Analysis - 'lavaan', verzija 0.6-3 (Rosseel, 2012a). Potpuni prikaz osnovnih značajki SEM analize premašuje ciljeve ovog rada, no u nastavku su ukratko opisani neki od najvažnijih elementa ovog analitičkog pristupa te koraci koje smo unutar SEM analize slijedili kako bismo odgovorili na postavljena istraživačka pitanja. O provjeri preduvjeta za provedbu SEM analize bit će više riječi u dijelu rada koji se odnosi na prikaz rezultata.

\section{4. 1. Osnovne značajke SEM analize}

SEM je široko korištena, multivarijatna metoda obrade podataka, kojom je moguće ispitati složene teorijske modele (Savalei i Falk, 2014). Unutar SEM modela moguće je paralelno ispitati odnose između većeg broja zavisnih i nezavisnih varijabli, a pritom je obje vrste varijabli u model moguće unijeti kao latentne faktore ili opažene varijable ${ }^{14}$ (Ullman i Bentler, 2013). SEM zapravo predstavlja skup statističkih postupaka, a najjednostavnije se može shvatiti kao kombinacija faktorske analize te analize traga (Weston i Gore, 2006). Naime, svaki SEM model moguće je raščlaniti na mjerni i strukturalni dio (Schreiber, Nora, Stage, Barlow i King, 2006). Mjernim modelom se specificiraju pretpostavljeni odnosi između latentnih faktora i njihovih opaženih indikatora. Testiranjem ovog dijela modela istraživač može provjeriti koliko dobro kombinacija opaženih varijabli identificira latentni konstrukt za

\footnotetext{
${ }^{13}$ Kontrola unosa je pokazala da su sve unesene vrijednosti bile unutar teorijskog raspona.

${ }^{14}$ U stručnoj se terminologiji, u okviru SEM analitičkih postupaka, za latentne varijable još koriste izrazi faktori, konstrukti ili neopažene varijable, dok se za opažene varijable još koriste izrazi indikatori ili manifestne varijable (Ullman i Bentler, 2013). Ovi će izrazi naizmjence biti korišteni i u ovom radu.
} 
koji se pretpostavlja da je u pozadini opaženih varijabli (Weston i Gore, 2006). Unutar SEM analize, mjerni dio modela se najčešće provjerava primjenom konfirmatorne faktorske analize (CFA) koja će biti korištena i u ovom istraživanju. Za razliku od eksploratorne faktorske analize (EFA), CFA je snažno vođena teorijom i/ili prethodnim empirijskim istraživanjima (Brown, 2015). Pri provjeri mjernog modela istraživač mora odrediti broj faktora u modelu, obrazac odnosa između faktora i opaženih varijabli te eventualne kovarijance između rezidualnih varijanci opaženih varijabli (Brown, 2015). Važna specifičnost CFA modela je što su u njima, za razliku od EFA modela, tzv. križne saturacije najčešće fiksirane na nulu (Brown, 2015). Drugim riječima, to znači da je u mjernim modelima svaka opažena varijabla najčešće zasićena samo jednim latentnim faktorom.

Strukturalni dio SEM modela se odnosi na specifikaciju odnosa između varijabli u modelu. Strukturalni odnosi se mogu specificirati kao kovarijance, izravne veze ili neizravne (medijacijske) veze. Kovarijance predstavljaju neusmjerene veze između varijabli, dok izravnim vezama pretpostavljamo smjer odnosa od jedne varijable prema drugoj, slično kao u analizi varijance te višestrukoj regresijskoj analizi (Weston i Gore, 2006). Parametri koji se izračunavaju za svaku usmjerenu vezu u SEM modelu interpretiraju se na sličan način kao klasični regresijski koeficijenti (Weston i Gore, 2006). Neizravni efekti se u SEM modelima definiraju i interpretiraju kao i unutar drugih analitičkih postupaka. Tako o neizravnom efektu govorimo kada se veza između dvije varijable u modelu ostvaruje preko medijacijskog efekta jedne ili više varijabli (Weston i Gore, 2006).

Opisana mjerna i strukturalna komponenta SEM modela se najčešće provjeravaju odvojeno (Anderson i Gerbing, 1988). Naime, odvojena provjera mjernog i strukturalnog modela olakšava istraživaču pronalaženje izvora eventualnog lošeg pristajanja modela podacima. Pored toga, nije opravdano provjeravati regresijske odnose u modelu prije postavljanja adekvatnog mjernog modela (Kline, 2015). Sljedeći ovu proceduru, u ovom smo istraživanju uvijek najprije provjerili pristajanje mjernog modela latentnih varijabli kroz provedbu CFA, a nakon toga bismo testirali strukturalne puteve u modelima, $\mathrm{tj}$. pretpostavljene veze između roditeljskih i učeničkih konstrukata.

Osim mjernog i strukturalnog modela, specifična terminologija koja se veže uz SEM analizu uključuje i tzv. endogene i egzogene varijable (Kline, 2015). Endogene (unutarnje) varijable su zavisne varijable za koje se u modelu pretpostavlja da ih uzrokuju druge varijable. S druge strane, uzroci egzogenih (vanjskih) varijabli nisu specificirani u SEM modelima.

SEM modeli se vizualno uobičajeno prikazuju pomoću tzv. dijagrama puta koji su korišteni i u ovom istraživanju. Pri izradi ovih dijagrama potrebno je slijediti određena pravila 
o grafičkoj prezentaciji pojedinih dijelova SEM modela (Kline, 2015). Primjerice, latentne varijable se u dijagramima puta prikazuju pomoću krugova ili elipsi, dok se opažene varijable prikazuju pomoću kvadrata ili pravokutnika. Usmjerene veze između varijabli se prikazuju pomoću jednosmjernih strelica $(\rightarrow)$, dok dvosmjerne strelice $(\leftrightarrow)$ predstavljaju korelaciju ${ }^{15}$, odnosno kovarijancu između dviju varijabli.

Primjena SEM analitičkih metoda obrade podataka $\mathrm{u}$ istraživanjima ima brojne prednosti. U slučajevima kada se ispituju strukturalni odnosi između latentnih varijabli, takvi su izračuni oslobođeni mjerne pogreške budući da se u SEM modelima varijanca mjerne pogreške može odvojiti od varijance koja je zajednička skupu indikatora i koja se pripisuje latentnom konstruktu. Iz tog razloga, SEM omogućuje utvrđivanja snažnijih veza između varijabli u odnosu na tradicionalne regresijske metode u kojima nije moguće iz analize izuzeti mjernu pogrešku budući da se u takvim analizama strukturalni odnosi ispituju na razini opaženih varijabli (Little, 2013). Procjena i uklanjanje mjerne pogreške također omogućuje direktnu procjenu pouzdanosti korištenih varijabli. Nadalje, kada su fenomeni koji su predmet interesa istraživača složeni i multidimenzionalni, kao što je slučaj i u ovom istraživanju, SEM je jedini analitički postupak koji omogućuje simultanu provjeru svih pretpostavljenih veza (Ullman i Bentler, 2013).

U društvenim se znanostima istraživačke hipoteze često postavljaju na razini konstrukata. Međutim, korištenjem drugih statističkih postupaka takve se hipoteze zapravo testiraju na razini opaženih varijabli. Neusklađenost razine istraživačkih hipoteza i razine obrade podataka može dovesti do netočnih istraživačkih zaključaka, što je problem koji je u istraživanjima često zanemaren. $U$ istraživanjima u području psihologije obrazovanja većina varijabli, kao što su, primjerice, obrazovne aspiracije učenika, različite učeničke percepcije i samoprocijenjena ponašanja, su zapravo latentni konstrukti (Schreiber i sur., 2006). Prednost SEM-a je upravo mogućnost provjere istraživačkih hipoteza na konstruktnoj razini (Ullman i Bentler, 2013; Weston i Gore, 2006).

Naposljetku treba napomenuti da iako u SEM modelima specificiramo kauzalne odnose između varijabli, ova tehnika sama po sebi ne omogućuje zaključke kauzalnog tipa. Samo valjanost korištene teorije te priroda istraživačkog nacrta omogućuju donošenje zaključaka o kauzalnosti (Weston i Gore, 2006).

\footnotetext{
${ }^{15} \mathrm{O}$ kovarijanci govorimo u dijagramu puta s nestandardiziranim parametrima, a o korelaciji u dijagramu puta sa standardiziranim parametrima (Kline, 2015).
} 


\section{4. 2. Evaluacija SEM modela}

Prvi korak u evaluaciji mjernog i strukturalnog modela jest evaluacija indeksa pristajanja modela podacima. Najstariji indeks pristajanja koji se koristi unutar SEM metodologije jest hi-kvadrat $\left(\chi^{2}\right)$. Statistička značajnost $\chi^{2}$ vrijednosti ukazuje da se reproducirana matrica varijanci i kovarijanci korištenih varijabli značajno razlikuje od empirijske matrice, odnosno, da postavljeni model ne opisuje dobro empirijske podatke. Međutim, poznato je da kod velikih uzoraka $\chi^{2}$ indeks redovito ukazuje na loše pristajanje modela podacima. Neki autori stoga preporučuju izračun omjera između $\chi^{2}$ indeksa i stupnjeva slobode $(d f)$. Ukoliko ovaj omjer ima vrijednost između jedan i pet, moguće je zaključiti da je pristajanje modela podacima prihvatljivo. Omjer koji je manji od tri ukazuje na dobro pristajanje, a omjer koji je manji od dva na vrlo dobro pristajanje modela podacima (Arbuckle i Wothke 1999). Ovaj omjer korišten je i pri evaluaciji SEM modela i u ovom istraživanju.

$S$ obzirom na njegove nedostatke, $\chi^{2}$ indeks nikada ne bi trebalo koristiti kao jedinu mjeru u evaluaciji SEM modela (Brown, 2015). Preporuča se da se pri evaluaciji modela u obzir uzme bar jedan indeks iz tri šire skupine pokazatelja pristajanja - skupine apsolutnog pristajanja, parsimoničnosti i skupine komparativnih indeksa (Brown, 2015). Pritom je važno napomenuti kako ne postoji opći konsenzus o prihvatljivim veličinama ovih indeksa, a njihova interpretacija može uvelike ovisiti o veličini uzorka te kompleksnosti modela. Međutim, u literaturi se navode pojedine granične vrijednosti za ove indekse koji mogu poslužiti kao opći vodič pri evaluaciji SEM modela. U nastavku su ukratko opisani indeksi iz sve tri skupine koji su korišteni u ovom istraživanju.

Iz skupine apsolutnog pristajanja, osim $\chi^{2}$ indeksa, najčešće se koristi SRMR indeks (engl. standardized root mean square residual). SRMR može poprimiti vrijednosti između $0 \mathrm{i}$ 1, pri čemu manja vrijednost ukazuje na bolje pristajanje modela podacima (Brown, 2015). Kline (2015) navodi da vrijednost SRMR indeksa koja je veća od .10 najčešće ukazuju na loše pristajanje modela podacima, dok Hu i Bentler (1999) navode vrijednost nižu od .08 za mogućnost zaključivanja o adekvatnosti modela. Iz skupine parsimonijskih indeksa koristili smo RMSEA indeks (engl. root mean square error of approximation). Kao i u slučaju SRMR indeksa, manje vrijednosti RMSEA indeksa ukazuju na bolje pristajanje modela podacima (Brown, 2015). Browne i Cudeck (1993; prema Brown, 2015) kao graničnu vrijednost za zaključivanje o adekvatnosti modela predlažu veličinu RMSEA indeksa manju od .08. Hu i Bentler (1999) navode nešto stroži kriterij - vrijednost jednaku ili nižu od .06. Kline (2015) navodi da je u idealnom slučaju RMSEA vrijednost manja ili jednaka .05, dok njezin interval 
sigurnost ne bi trebao prelaziti graničnu vrijednost od .10. Naposljetku, iz skupine komparativnih indeksa koristili smo CFI (engl. comparative fit index) i TLI indekse (engl. Tucker-Lewis index). CFI može poprimiti vrijednost između 0 i 1, a veće vrijednosti ukazuju na bolje pristajanje modela. TLI može imati i vrijednost i izvan ovog raspona, ali se interpretira slično kao CFI - veća vrijednost je indikator boljeg pristajanja modela. Neki metodičari za CFI te TLI indekse kao adekvatne navode vrijednosti između .90 i .95, dok se za vrijednosti ispod .90 smatra da su indikatori nedostatnog pristajanja modela (Brown, 2015). S duge strane, često se kao granična vrijednost navodi i vrijednost iznad .95 (npr., Hu i Bentler, 1999). Prema Millsapu (2011) možemo govoriti o dobrom i prihvatljivom pristajanju modela podacima. Model koji dobro pristaje podacima ima sljedeće vrijednosti indeksa pristajanja: CFI $\geq 0.95$, RMSEA $\leq 0.05$, SRMR $\leq 0.05$, dok model koji ima prihvatljivo pristajanje podacima ima sljedeće indekse pristajanja: $\mathrm{CFI} \geq 0.90, \mathrm{RMSEA} \leq 0.08, \mathrm{SRMR} \leq 0.08$.

Osim provjere općeg pristajanja modela podacima, kod evaluacije SEM modela razmotrili smo i procijenjene parametre u vidu njihove statističke značajnosti, veličine i teorijske interpretabilnosti. Pri evaluaciji parametara u mjernom (CFA) modelu treba voditi računa o faktorskim zasićenjima, varijancama faktora i kovarijancama između faktora te o mjernim pogreškama (Brown, 2015). Prema statističkim kriterijima, ovi parametri ne bi smjeli imati vrijednosti izvan određenih teorijskih raspona. Standardizirane korelacije među faktorima ne smiju imati vrijednost veću od jedan, a varijance faktora i mjernih pogrešaka moraju imati pozitivnu vrijednost. Slučajevi nezadovoljavanja ovih kriterija, koji se u literaturi nazivaju Heywood slučajevima, najčešće ukazuju na pogreške u specifikaciji modela ili na probleme s veličinom uzorka ili ulaznom matricom varijanci i kovarijanci (Brown, 2015).

Nadalje smo provjerili statističku značajnost i veličinu pojedinih parametara. Sve procijenjene faktorske saturacije bi trebale biti statistički značajne i adekvatne veličine. Hair, Black, Babin i Anderson (2010) navode da bi u CFA modelima standardizirana faktorska zasićenja trebala iznositi barem 0.50, a u idealnom slučaju barem 0.70. Također smo provjerili korelacije između latentnih faktora koje se ne bi smjele približavati potpunoj korelaciji. Naime, u primijenjenim istraživanjima korelacije među faktorima koje premašuju vrijednost od .80 ili .85 ukazuju na lošu diskriminativnu valjanost, odnosno preveliko preklapanje u latentnim faktorima (Brown, 2015). Osim evaluacije parametara u mjernom modelu, važno je interpretirati i parametre strukturalnog modela, što je opisano u narednom poglavlju. 


\section{4. 3. Ispitivanje izravnih i medijacijskih veza u SEM modelu}

Kao što smo već spomenuli, izravne se veze u SEM modelima interpretiraju na sličan način kao u regresijskoj analizi, odnosno, interpretiraju se procijenjeni regresijski koeficijenti. Zbog mogućih razlika u mjernim skalama ispitivanih varijabli, umjesto nestandardiziranih, obično se interpretiraju standardizirani regresijski koeficijenti (Ullman i Bentler, 2013). U kompleksnim modelima, kao što su modeli koji su testirani u ovom istraživanju, SEM omogućuje i procjenu izravnog efekta varijable X na varijablu Y, uz istovremenu kontrolu svih drugih varijabli za koje je u modelu specificirano da utječu na Y (Kline, 2015).

Kod ispitivanja pretpostavljenih medijacijskih veza, potrebno je najprije utvrditi značajnost izravnog, neizravnog i totalnog učinka (Gunzler, Chen, Wu i Zhang, 2013). Unutar medijacijskih SEM modela izravni učinak predstavlja strukturalni put između egzogene varijable i kriterijske varijable uz kontrolu medijatorske varijable. Neizravni učinak je put od egzogene varijable do kriterijske varijable kroz medijatorsku varijablu. On se izračunava kao umnožak strukturalnog puta od egzogene varijable do medijatorske varijable te puta od medijatorske varijable do kriterijske varijable. Naposljetku, totalni učinak predstavlja zbroj izravnog i neizravnog učinka egzogene varijable na kriterijsku varijablu (Gunzler i sur., 2013). Unutar paketa 'lavaan' moguće je izračunati veličinu i statističku značajnost standardiziranih beta koeficijenata za sva tri navedene vrste učinaka ${ }^{16}$.

Osnovna medijacijska hipoteza je da se utjecaj nezavisne varijable na zavisnu ostvaruje preko promjene u medijacijskoj varijabli. Ukoliko je riječ o potpunoj medijaciji, učinak nezavisne na zavisnu varijablu u potpunosti se ostvaruje na ovaj način. U takvom je modelu ranije opisani izravni učinak statistički neznačajan. Međutim, u većini je istraživanja mnogo češći slučaj tzv. parcijalne medijacije. Kod parcijalne medijacije učinak nezavisne na zavisnu varijablu samo se djelomično ostvaruje preko medijatorske varijable. Drugim riječima, u takvom se modelu izravan učinak nezavisne na zavisnu varijablu zadržava čak i kada se u model uključi medijatorska varijabla (Gunzler i sur., 2013).

U ovom smo istraživanju pri određivanju konačnog strukturalnog modela koristili tzv. pristup rezanja modela (engl. model trimming). Kroz ovaj se postupak barem jedan ili više slobodnih parametara koji su se pokazali statistički neznačajnima fiksira na nulu, čime model

\footnotetext{
${ }^{16}$ Kako bi se ovi učinci mogli procijeniti, potrebno im je dodati direktne oznake unutar 'lavaan' sintakse (za više detalja vidi Rosseel, 2019).
} 
postaje sve jednostavniji, sljedeći načelo parsimonije ${ }^{17}$ (Kline, 2015). S uklanjanjem slobodnih parametara, opće pristajanje modela podacima najčešće postaje sve lošije, tj. vrijednost hikvadrat indeksa raste. Cilj rezanja modela je pronaći što jednostavniji model koji pokazuje adekvatno specificiranu strukturu kovarijanci i koji je teorijski opravdan (Kline, 2015). Kako bismo utvrdili dovodi li fiksiranje neznačajnih puteva na nulu do značajnog pogoršanja u pristajanju modela podacima, koristili smo kriterije za usporedbu ugniježđenih modela (engl. nested models) (Kline, 2015). Kroz ovu se metodu pristajanje jednostavnijeg modela uspoređuje s pristajanjem složenijeg modela na temelju ispitivanja značajnosti razlike $\mathrm{u} \chi^{2}$ indeksu $\left(\Delta \chi^{2}\right)$ dva modela ${ }^{18}$. Stupnjevi slobode $\left(d f_{D}\right)$ koji se vežu uz $\Delta \chi^{2}$ vrijednost predstavljaju razliku stupnjeva slobode između dva modela koja uspoređujemo (Kline, 2015). Ukoliko model koji je parsimoničniji ne pristaje podacima značajno lošije nego model s većim brojem procijenjenih parametara opravdano je prihvatiti jednostavniji model.

\section{4. 4. Ispitivanje moderatorskih učinaka u SEM modelu}

Kako bismo odgovorili na drugi istraživački problem, proveli smo tzv. multigrupnu SEM analizu. Osnovni cilj ove analize je utvrditi razlikuju li se pojedini parametri u SEM modelima značajno u skupinama koje čine različiti uzorci. U našem su istraživanju ti uzorci bili učenici muškog i ženskog roda te učenici čiji su roditelji nižeg i višeg obrazovanja. U multigrupnoj SEM analizi se najprije izračunaju nestandardizirane vrijednosti parametara koji nas zanimaju tako da one budu jednake za oba uzorka koja uspoređujemo. Pristajanje ovog, tzv. ograničenog modela (engl. constrained model) se potom uspoređuje s pristajanjem modela u kojem su isti parametri oslobođeni tako da mogu varirati među skupinama. Ukoliko je pristajanje ograničenog modela podacima značajno lošije, moguće je zaključiti da uspoređivani parametri nisu jednaki kod dva uzorka (Kline, 2015).

Kako bismo mogli zaključivati o strukturalnoj invarijantnosti modela, odnosno o tome razlikuju li se pojedini strukturalni putevi za dva uspoređivana uzorka, potrebno je najprije utvrditi postojanje određene razine invarijantnosti u mjernom modelu. Smatra se da je tzv. metrijska ili slaba invarijantnost dovoljna za valjano uspoređivanje strukturalnih puteva

\footnotetext{
${ }^{17}$ Unutar SEM analitičkih postupaka, tzv načelo parsimonije govori da između dva modela koji podjednako dobro pristaju podacima treba zadržati onaj model koji je jednostavniji, tj. model koji ima manji broj procijenjenih parametara (Kline, 2015).

${ }^{18}$ Kada se kao metoda procjene parametara koristi MLR metoda, kao što je slučaj u ovom istraživanju, za testiranje razlike u pristajanju modela koristi se tzv. Satorra-Bentler test razlike hi-kvadrata (Satorra i Bentler, 2001).
} 
između različitih skupina (Cieciuch, Davidov, Schmidt, Algesheimer i Schwartz 2014). Metrijska invarijantnost znači da se faktorske saturacije u mjernom modelu ne razlikuju značajno za dvije uspoređivane skupine. Kako bi se utvrdila ova razina invarijantnosti, potrebno je najprije testirati tzv. konfiguralnu invarijantnost. Ova vrsta invarijantnosti podrazumijeva da se pojedini latentni konstrukti u mjernom modelu sastoje od istih indikatora u obje uspoređivane skupine. Konfiguralna invarijantnost se procjenjuje na temelju pristajanja multigrupnog SEM modela u kojem nijedan parametar nije ograničen da bude jednak u obje skupine (Millsap, 2011). Ukoliko se ova vrsta invarijantnosti utvrdi, konfiguralni SEM model se uspoređuje s modelom koji podrazumijeva metrijsku invarijantnost. U slučaju kad ne postoji razlika u pristajanju ova dva modela, moguće je zaključiti da su faktorske saturacije slične u uspoređivanim skupinama. Potom se na isti način može provjeriti strukturalna invarijantnost model s metrijskom invarijantnosti se uspoređuje s modelom u kojem su svi ili određeni strukturalni putevi ograničeni da budu jednaki među skupinama. Ukoliko model s ograničenim putevima ne pristaje podacima značajno lošije nego model u kojem su ograničena samo faktorska zasićenja, možemo zaključiti da su testirani putevi u dvama skupinama jednaki. Usporedbe modela u okviru multigrupne analize provedene su već opisanom metodom usporedbe ugniježđenih modela, odnosno, provjerom razlike u hi-kvadrat indeksima. 


\section{REZULTATI}

\section{1. Preliminarne analize}

\section{1. 1. Analiza i tretman podataka koji nedostaju}

Analiza podataka koji nedostaju pokazala je da je postotak takvih slučajeva u ovom istraživanju bio nizak. Postotak nedostajućih vrijednosti se kretao od nula u slučaju varijabli roda i dobne kohorte učenika do maksimalne vrijednosti od $5.5 \%$ za varijablu obrazovanja roditelja. Ako se u obzir uzmu sve varijable izuzev obrazovanja roditelja, prosječni postotak nedostajućih vrijednosti bio je vrlo nizak te je iznosio $1.29 \%$, dok je maksimalni postotak nedostajanja iznosio $3.2 \%$. U skupini čestica koje se odnose na roditeljska uvjerenja specifična za dijete, postotak nedogovaranja se kretao između 0.8 i $2.3 \%$. Od 16 čestica u ovoj skupini (osam čestica je vezano uz matematiku i osam uz tehničku kulturu), na njih 13 je postotak vrijednosti koje nedostaju bio ispod $2 \%$. Na preostale tri čestice je taj postotak bio malo viši od $2 \%$. Dvije od tih čestica su se odnosile na pitanje „U usporedbi s ostalom djecom, što mislite, koliko je Vaše dijete uspješno u (matematici/tehničkoj kulturi)?“‘. Moguće je da neki roditelji nisu mogli ili nisu željeli svoju djecu uspoređivati prema sposobnostima s drugom djecom u razredu, što bi objasnilo zašto je na ovoj čestici za oba nastavna predmeta postotak neodgovaranja bio nešto viši nego na ostalim česticama koje nisu od roditelja zahtijevale uspoređivanje njihovog djeteta s drugom djecom.

U skupini čestica koje se odnose na učenička motivacijska uvjerenja postotak nedostajućih vrijednosti je bio vrlo nizak te se kretao između 0.2 i $0.9 \%$, osim u slučaju čestice „Kada trebaš naučiti nešto novo iz matematike, kako ti to ide?“ na kojoj je postotak neodgovaranja bio $3.1 \%$. Poznato je da kod velikog broja učenika matematičke aktivnosti i zadaci izazivaju tzv. matematičku anksioznost, odnosno, negativne afektivne reakcije (Ashcraft, 2002; Maloney i Beilock, 2012). Stoga je moguće da je ovo pitanje kod dijela učenika izazvalo negativnu emocionalnu reakciju, što bi objasnilo zašto je na ovoj čestici značajno viša stopa neodgovaranja u usporedbi s ostalim česticama u skupini.

U skupini čestica koje se odnose na konstrukte roditeljskih ponašanja, postotak nedostajućih vrijednosti se kretao između $0.8 \%$ i $3.2 \%$, dok se u skupini čestica koje se odnose na učenička ponašanja taj postotak kretao između 0.8 i $1.8 \%$. Među sociodemografskim varijablama i varijablama vezanim uz učeničko postignuće, stopa nedostajućih vrijednosti je 
bila vrlo niska (između 0 i $0.8 \%$ ), izuzev već spomenute varijable obrazovanja roditelja sa stopom neodgovaranja od $5.5 \%$.

S obzirom da je stopa neodgovaranja u ovom istraživanju bila niska, odlučeno je da će se u okviru SEM analiza, koje predstavljaju primarnu metodu obrade podataka u ovom istraživanju, nedostajuće vrijednosti tretirati primjenom metode najveće vjerojatnosti (engl. full information maximum likelihood - FIML) ${ }^{19}$. FIML predstavlja naprednu metodu tretmana nedostajućih vrijednosti, koja se po učinkovitosti može usporediti s višestrukim imputacijama i koja ima brojne prednosti u odnosu na tradicionalne metode tretmana nedostajućih vrijednosti, kao što je isključivanje iz analize onih sudionika za koje nedostaje bilo koji od podataka koji su uključeni u analizu (engl. listwise deletion) te zadržavanje ispitanika koji imaju podatak bar na nekoj od varijabli ili parovima varijabli uključenih u analizu (engl. pairwise deletion) (Allison, 2003). FIML zamjenjuje podatke koji nedostaju koristeći opažene podatke koji su dostupni za svakog sudionika (Little, Jorgensen, Lang i Moore, 2014). U ostalim, preliminarnim analizama (korelacijskim analizama i t-testovima prikazanim u ovom potpoglavlju), korištena je listwise ili pairwise metoda tretmana nedostajućih vrijednosti.

Dodatno smo u ovom dijelu provjerili razlikuju li se učenici čiji su roditelji pristali sudjelovati u istraživanju od učenika čiji roditelji nisu sudjelovali u istraživanju. Provjerili smo razlikuju li se ove dvije skupine učenika u obrazovnim ishodima u matematici i tehničkoj kulturi - postignuću, motivacijskim uvjerenjima u ovim predmetima i bavljenju slobodnim aktivnostima u matematičkom i tehničkom području. Naime, rezultati ove analize mogu ukazati na potencijalnu pristranost uzorka s obzirom da smo u istraživanje uključili samo one učenike za koje smo imali i podatke njihovih roditelja. Prije provedbe analize, formirane su kompozitne varijable motivacijskih uvjerenja, slobodnih aktivnosti i školskog postignuća kao prosjeci pripadajućih čestica. Kako bismo ostvarili veću varijancu mjere učeničkog postignuća u matematici i tehničkoj kulturi, za potrebe ove specifične analize, koristili smo prosječnu vrijednost kontrolne i kriterijske zaključne ocjene iz predmeta.

$\mathrm{S}$ obzirom da je u svrhu ove analize provedeno ukupno deset nezavisnih t-testova (pet mjera $\times$ dva nastavna predmeta), $\mathrm{s}$ ciljem kontrole vjerojatnosti pogreške tipa $\mathrm{I}$, Bonferronijevom korekcijom je razina značajnosti postavljena na .005 $(\alpha=.05 / 10)$. Detaljan prikaz rezultata provedenih t-testova dostupan je u Prilogu 2. Kao što je vidljivo, učenici čiji su

\footnotetext{
${ }^{19}$ U literaturi se pri referiranju na ovu metodu koriste pojmovi "full information maximum likelihood (FIML)", "maximum likelihood (ML)", "direct maximum likelihood" i "raw maximum likelihood" (vidi Allison, 2003). U Rovom paketu lavaan, za ovu metodu tretmana nedostajućih vrijednosti potrebno je kao vrijednost argumenta 'missing' unijeti 'direct', 'ml' ili 'fiml'. Pritom je uvjet za korištenje FIML-a da je kao metoda procjena parametara u modelu odabrana metoda najveće vjerojatnosti (Rosseel, 2012b).
} 
roditelji sudjelovali $\mathrm{u}$ istraživanju imali su nešto više školsko postignuće iz matematike $(t=$ $3.63 ; p<.001)$ te su izvijestili o nešto višoj samoefikasnosti u matematici $(t=2.94 ; p=.003)$ od učenika čiji roditelji nisu sudjelovali u istraživanju. No, ako u obzir uzmemo Cohenovu veličinu učinka (1988), vidljivo je da je riječ o malim razlikama: $d$ iznosi 0.34 za razliku u postignuću te 0.27 za razliku u samoefikasnosti.

\section{1. 2. Deskriptivni podaci i povezanost varijabli korištenih u istraživanju}

Osnovni deskriptivni podaci (broj čestica, opaženi i teorijski raspon rezultata, aritmetička sredina, standardna devijacija i parametri normalnosti distribucije) za roditeljske varijable korištene u ovom istraživanju prikazani su u Tablici 2. U Tablici 3 prikazani su isti deskriptivni podaci za korištene učeničke varijable. 
Tablica 2. Deskriptivni parametri roditeljskih varijabli korištenih u istraživanju $(N=1064)$

\begin{tabular}{|c|c|c|c|c|c|c|}
\hline Varijabla & $\begin{array}{l}\text { Broj } \\
\text { čestica }\end{array}$ & $\begin{array}{c}\text { Raspon } \\
\text { (Teorijski } \\
\text { raspon) }\end{array}$ & $M$ & $S D$ & Asimetričnost & Spljoštenost \\
\hline \multicolumn{7}{|l|}{ Matematika } \\
\hline $\begin{array}{l}\text { Percepcija djetetovih } \\
\text { sposobnosti u } \\
\text { predmetu }\end{array}$ & 4 & $1-7(1-7)$ & 4.64 & 1.41 & -0.17 & -0.70 \\
\hline $\begin{array}{l}\text { Percepcija korisnosti } \\
\text { predmeta za dijete }\end{array}$ & 2 & $1-7(1-7)$ & 6.06 & 1.20 & -1.37 & 1.37 \\
\hline $\begin{array}{l}\text { Percepcija djetetovog } \\
\text { interesa za predmet }\end{array}$ & 1 & $1-7(1-7)$ & 4.59 & 1.71 & -0.24 & -0.86 \\
\hline $\begin{array}{l}\text { Percepcija djetetovog } \\
\text { truda u predmetu }\end{array}$ & 1 & $1-7(1-7)$ & 4.98 & 1.66 & -0.49 & -0.72 \\
\hline $\begin{array}{c}\text { Modeliranje } \\
\text { aktivnosti u području }\end{array}$ & 2 & $1-6(1-6)$ & 3.52 & 1.29 & -0.16 & -0.65 \\
\hline $\begin{array}{l}\text { Uključenost u } \\
\text { djetetove aktivnosti } \\
\text { iz predmeta }\end{array}$ & 3 & $1-5(1-5)$ & 3.08 & 1.04 & 0.09 & -0.67 \\
\hline $\begin{array}{l}\text { Poticanje djetetovih } \\
\text { interesa u području }\end{array}$ & 3 & $1-5(1-5)$ & 3.22 & 0.83 & -0.17 & -0.08 \\
\hline
\end{tabular}

\section{Tehnička kultura}

\begin{tabular}{|c|c|c|c|c|c|c|}
\hline $\begin{array}{l}\text { Percepcija djetetovih } \\
\text { sposobnosti u } \\
\text { predmetu }\end{array}$ & 4 & $1.75-7(1-7)$ & 5.46 & 1.05 & -0.52 & -0.25 \\
\hline $\begin{array}{l}\text { Percepcija korisnosti } \\
\text { predmeta za dijete }\end{array}$ & 2 & $1-7(1-7)$ & 4.93 & 1.51 & -0.51 & -0.33 \\
\hline $\begin{array}{l}\text { Percepcija djetetovog } \\
\text { interesa za predmet }\end{array}$ & 1 & $1-7(1-7)$ & 5.06 & 1.49 & -0.63 & -0.27 \\
\hline $\begin{array}{l}\text { Percepcija djetetovog } \\
\text { truda u predmetu }\end{array}$ & 1 & $1-7(1-7)$ & 5.16 & 1.55 & 0.13 & -0.65 \\
\hline $\begin{array}{l}\text { Modeliranje } \\
\text { aktivnosti u području }\end{array}$ & 3 & $1-6(1-6)$ & 3.08 & 1.19 & 0.53 & -0.38 \\
\hline $\begin{array}{l}\text { Uključenost u } \\
\text { djetetove aktivnosti } \\
\text { iz predmeta }\end{array}$ & 3 & $1-5(1-5)$ & 2.42 & 1.05 & 0.01 & -0.35 \\
\hline $\begin{array}{l}\text { Poticanje djetetovih } \\
\text { interesa u području }\end{array}$ & 4 & $1-5(1-5)$ & 2.98 & 0.87 & -0.63 & -0.27 \\
\hline $\begin{array}{c}\text { Pribavljanje STEM } \\
\text { materijala }\end{array}$ & 7 & $0-7(0-7)$ & 2.69 & 1.86 & 0.31 & -0.79 \\
\hline $\begin{array}{l}\text { Obrazovanje } \\
\text { roditelja }\end{array}$ & 1 & $1-6(1-6)$ & 3.29 & 1.50 & 0.39 & -1.38 \\
\hline
\end{tabular}


Tablica 3. Deskriptivni parametri učeničkih varijabli korištenih u istraživanju $(N=1064)$

\begin{tabular}{|c|c|c|c|c|c|c|}
\hline Varijabla & $\underset{\text { čestica }}{\text { Broj }}$ & $\begin{array}{c}\text { Raspon } \\
\text { (Teorijski } \\
\text { raspon) } \\
\end{array}$ & $M$ & $S D$ & Asimetričnost & Spljoštenost \\
\hline \multicolumn{7}{|l|}{ Matematika } \\
\hline $\begin{array}{c}\text { Samoefikasnost u } \\
\text { predmetu }\end{array}$ & 4 & $1-7(1-7)$ & 4.67 & 1.39 & -0.29 & -0.53 \\
\hline Interes za predmet & 4 & $1-7(1-7)$ & 4.17 & 1.47 & -0.14 & -0.50 \\
\hline Važnost predmeta & 4 & $1-7(1-7)$ & 5.41 & 1.10 & -0.80 & 0.53 \\
\hline $\begin{array}{l}\text { Slobodne aktivnosti } \\
\text { u području }\end{array}$ & 3 & $1-5(1-5)$ & 2.54 & 0.97 & 0.34 & -0.38 \\
\hline $\begin{array}{c}\text { Postignuće- } \\
\text { kontrolna mjera }\end{array}$ & 1 & $2-5(1-5)$ & 3.71 & 1.06 & -0.25 & -1.18 \\
\hline $\begin{array}{c}\text { Postignuće - } \\
\text { kriterijska mjera }\end{array}$ & 1 & $1-5(1-5)$ & 3.61 & 1.13 & -0.24 & -1.14 \\
\hline \multicolumn{7}{|l|}{ Tehnička kultura } \\
\hline $\begin{array}{c}\text { Samoefikasnost u } \\
\text { predmetu }\end{array}$ & 5 & $1-7(1-7)$ & 5.50 & 1.22 & -0.74 & 0.02 \\
\hline Interes za predmet & 4 & $1-7(1-7)$ & 4.28 & 1.77 & -0.21 & -0.93 \\
\hline Važnost predmeta & 4 & $1-7(1-7)$ & 4.30 & 1.43 & -0.22 & -0.27 \\
\hline $\begin{array}{c}\text { Slobodne aktivnosti } \\
\text { u području }\end{array}$ & 4 & $1-5(1-5)$ & 2.50 & 0.96 & 0.48 & -0.33 \\
\hline $\begin{array}{c}\text { Postignuće - } \\
\text { kontrolna mjera }\end{array}$ & 1 & $2-5(1-5)$ & 4.59 & 0.62 & -1.30 & 0.80 \\
\hline $\begin{array}{c}\text { Postignuće - } \\
\text { kriterijska mjera }\end{array}$ & 1 & $2-5(1-5)$ & 4.65 & 0.59 & -1.57 & 1.97 \\
\hline
\end{tabular}

Pearsonove korelacije između svih učeničkih i roditeljskih varijabli korištenih $\mathrm{u}$ istraživanju prikazane su u Tablici 4. Pregled ovih korelacija može pružiti inicijalnu podršku odnosima koji su pretpostavljeni konceptualnim modelom roditeljskih odrednica učeničkih obrazovnih ishoda u matematici i tehničkoj kulturi koji će biti provjeren u sklopu prvog istraživačkog problema. U pogledu hipoteza vezanih uz distalne roditeljske karakteristike, pokazalo se da je obrazovanje roditelja pozitivno povezano s roditeljskim uvjerenjima specifičnim za dijete, no samo u matematici $(r=.11$ do $.32 ; p<.001)$, ali ne i u tehničkoj kulturi. Više obrazovanje roditelja povezano je s većim roditeljskim pribavljanjem materijala u STEM području $(r=16 ; p<.001)$ te $\mathrm{s}$ češćim roditeljskim poticanjem tehničkih $(r=17 ; p<$ .001 ), ali ne i matematičkih aktivnosti djeteta. Obrazovanje roditelja je pozitivno povezano s 
učeničkim postignućem i iz matematike $(r=38 ; p<.001)$ i iz tehničke kulture $(r=30 ; p<.001)$ te $\mathrm{s}$ učeničkom samoefikasnosti u matematici $(r=.27 ; p<.001)$, ali ne i s učeničkom samoefikasnosti u tehničkoj kulturi.

U pogledu pretpostavljenih odnosa koji uključuju roditeljska uvjerenja specifična za dijete u matematici i tehničkoj kulturi, pokazalo se da su sve varijable roditeljskih uvjerenja u matematici umjereno do snažno pozitivno povezane s učeničkim prethodnim postignućem iz matematike $(r=.30$ do $.77 ; p<.001)$. Roditeljska uvjerenja u tehničkoj kulturi su također pozitivno povezana $\mathrm{s}$ učeničkim prethodnim postignućem $\mathrm{u}$ ovom predmetu, iako su ove korelacije nešto niže u odnosu na korelacije u području matematike $(r=.09$ do $.43 ; p<.01)$. Sličan obrazac odnosa utvrđen je i za korelacije između roditeljskih uvjerenja i kasnijeg učeničkog postignuća iz matematike i tehničke kulture. Ove korelacije su umjerene do snažne u području matematike ( $r=.31$ do $.76 ; p<.001)$ te niske do umjerene u području tehničke kulture $(r=.10$ do $.38 ; p<.001)$. Niže korelacije roditeljskih uvjerenja i učeničkog postignuća iz tehničke kulture mogu se vjerojatno pripisati izrazito malom varijabilitetu učeničkih ocjena iz tehničke kulture.

Nadalje, korelacijska matrica pruža inicijalne dokaze o povezanosti između roditeljskih uvjerenja specifičnih za dijete i učeničkih motivacijskih uvjerenja u predmetu. U području matematike, zabilježene su niske do snažne pozitivne korelacije između ove dvije skupine varijabli ( $r=.25$ do $.75 ; p<.001)$, dok su u području tehničke kulture zabilježene niske do umjerene pozitivne korelacije između ove dvije skupine varijabli ( $r=.13$ do $.47 ; p<.001)$. U ovoj skupini korelacija, i u matematici, i u tehničkoj kulturi najsnažnija korelacija je utvrđena između roditeljske percepcije djetetove sposobnosti u predmetu i djetetove samoefikasnosti u istom predmetu (matematika: $r=.75 ; p<.001$; tehnička kultura: $r=.47 ; p<.001$ ). 
Tablica 4. Interkorelacije (Personov $r$ ) opaženih varijabli korištenih u istraživanju (korelacije varijabli vezanih uz matematiku su ispod dijagonale, a varijabli vezanih uz tehničku kulturu iznad dijagonale) $(N=1064)$

\begin{tabular}{|c|c|c|c|c|c|c|c|c|c|c|c|c|c|c|c|c|c|}
\hline Varijable & 1. & 2. & 3. & 4. & 5. & 6. & 7. & 8. & 9. & 10. & 11. & 12. & 13. & 14. & 15. & 16. & 17. \\
\hline 1. Rod učenika & 1 & -.01 & -.04 & $.10^{* *}$ & $-.19^{* *}$ & $-.07^{*}$ & .05 & .00 & $-.09^{* *}$ & $-.17^{* * *}$ & $-.15^{* * *}$ & $.07^{*}$ & $-.17^{* * * *}$ & $-.17^{* * *}$ & $-.13^{* * *}$ & $.20^{* * *}$ & $.18^{* * *}$ \\
\hline 2. Razred & -.01 & 1 & .00 & .01 & -.06 & $-.09^{* *}$ & $-.06^{*}$ & -.04 & -.06 & $-.07^{*}$ & -.02 & .04 & $-.08^{* *}$ & $-.08^{*}$ & $-.09^{* *}$ & -.05 & .00 \\
\hline 3. Obr. roditelj & -.04 & .00 & 1 & .06 & .02 & -.05 & $-.06^{*}$ & $.07^{*}$ & $-.06^{*}$ & $.17^{* * *}$ & $.16^{* * *}$ & -.03 & $-.18^{* * *}$ & $-.15^{* * *}$ & $.09^{* *}$ & $.26^{* * *}$ & $.30^{* * *}$ \\
\hline 4. Perc. sposob. & .03 & -.03 & $.32^{* * *}$ & 1 & $.27^{* * *}$ & $.60^{* * *}$ & $.38^{* * *}$ & $.10^{* *}$ & $-.13^{* * *}$ & $.12^{* * *}$ & $.13^{* * *}$ & $.47^{* * * *}$ & $.24^{* * *}$ & $.18^{* * *}$ & $.16^{* * *}$ & $.43^{* * *}$ & $.38^{* * *}$ \\
\hline 5. Perc. koristi & -.01 & -.02 & $.11^{* * * *}$ & $.38^{* * * *}$ & 1 & $.44^{* * *}$ & $.26^{* * *}$ & $.17^{* * *}$ & $.13^{* * *}$ & $.28^{* * *}$ & $.22^{* * *}$ & $.19^{* * *}$ & $.28^{* * *}$ & $.31^{* * *}$ & $.19^{* * *}$ & $.09^{* *}$ & $.10^{* *}$ \\
\hline 6. Perc. interesa & $.07^{*}$ & -.06 & $.23^{* * *}$ & $.81^{* * * *}$ & $.40^{* * *}$ & 1 & $.52^{* * * *}$ & $.12^{* * *}$ & .02 & $.24^{* * *}$ & $.19^{* * *}$ & $.36^{* * *}$ & $.36^{* * *}$ & $.29^{* * *}$ & $.21^{* * *}$ & $.21^{* * *}$ & $.17^{* * *}$ \\
\hline 7. Perc. truda & $.17^{* * *}$ & -.02 & $.15^{* * *}$ & $.44^{* * *}$ & $.23^{* * *}$ & $.56^{* * *}$ & 1 & .05 & $.12^{* * *}$ & $.15^{* * *}$ & $.10^{* * *}$ & $.16^{* * *}$ & $.14^{* * *}$ & $.13^{* * *}$ & $.13^{* * *}$ & $.16^{* * *}$ & $.16^{* * *}$ \\
\hline 8. Modeliranje & -.04 & .02 & $.09^{* *}$ & $.12^{* * *}$ & $.14^{* * *}$ & $.13^{* * *}$ & $.10^{* *}$ & 1 & $.29^{* * *}$ & $.49^{* * *}$ & $.31^{* * *}$ & .06 & $.11^{* * *}$ & $.13^{* * *}$ & $.12^{* * *}$ & .01 & .03 \\
\hline 9. Uključenost & -.03 & -.03 & -.04 & $-.36^{* * *}$ & $-.09^{* *}$ & $-.28^{* * * *}$ & .01 & $.25^{* * *}$ & 1 & $.28^{* * *}$ & $.24^{* * * *}$ & $-.07^{*}$ & $.12^{* * *}$ & $.15^{* * *}$ & $.08^{* *}$ & $-.18^{* * *}$ & $-.15^{* * *}$ \\
\hline 10. Poticanje & -.04 & -.01 & .04 & $.11^{* * *}$ & $.21^{* * * *}$ & $.18^{* * *}$ & $.21^{* * *}$ & $.52^{* * *}$ & $.31^{* * *}$ & 1 & $.46^{* * *}$ & $.10^{* *}$ & $.13^{* * *}$ & $.15^{* * *}$ & $.34^{* * *}$ & $.09^{* *}$ & $.12^{* * * *}$ \\
\hline 11. Pribavljanje & $-.15^{* * *}$ & -.02 & $.16^{* * *}$ & $.18^{* * *}$ & $.17^{* * *}$ & $.20^{* * *}$ & $.07^{*}$ & $.34^{* * *}$ & $.15^{* * *}$ & $.40^{* * *}$ & 1 & .03 & $.08^{*}$ & $.11^{* * *}$ & $.21^{* * *}$ & $.08^{*}$ & $.11^{* * *}$ \\
\hline 12.Samoefikas. & .02 & -.04 & $.27^{* * *}$ & $.75^{* * * *}$ & $.33^{* * *}$ & $.65^{* * *}$ & $.39^{* * * *}$ & $.10^{* *}$ & $-.31^{* * *}$ & $.13^{* * *}$ & $.16^{* * *}$ & 1 & $.53^{* * *}$ & $.41^{* * *}$ & $.20^{* * *}$ & $.30^{* * *}$ & $.29^{* * * *}$ \\
\hline 13. Interes & -.01 & $-.08^{* *}$ & $.15^{* * *}$ & $.43^{* * *}$ & $.26^{* * *}$ & $.47^{* * *}$ & $.25^{* * *}$ & $.07^{*}$ & $-.17^{* * *}$ & $.17^{* * *}$ & $.17^{* * *}$ & $.65^{* * *}$ & 1 & $.77^{* * *}$ & $.32^{* * *}$ & -.02 & -.02 \\
\hline 14. Važnost & $.06^{*}$ & $-.18^{* * *}$ & $.10^{* *}$ & $.30^{* * *}$ & $.31^{* * * *}$ & $.35^{* * *}$ & $.24^{* * *}$ & $.07^{*}$ & $-.07^{*}$ & $.12^{* * *}$ & $.11^{* * *}$ & $.46^{* * *}$ & $.57^{* * *}$ & 1 & $.28^{* * *}$ & -.01 & .00 \\
\hline 15. Sl. aktivn. & -.02 & $-.13^{* * *}$ & $.10^{* *}$ & $.26^{* * *}$ & $.18^{* * *}$ & $.28^{* * *}$ & $.18^{* * * *}$ & $.11^{* * *}$ & $-.09^{* *}$ & $.19^{* * *}$ & $.17^{* * *}$ & $.39^{* * *}$ & $.50^{* * *}$ & $.37^{* * *}$ & 1 & $.10^{* *}$ & $.11^{* * *}$ \\
\hline 16. Ocjena I & $.13^{* * * *}$ & $-.08^{* *}$ & $.39^{* * *}$ & $.77^{* * * *}$ & $.30^{* * *}$ & $.63^{* * *}$ & $.42^{* * *}$ & $.09^{* *}$ & $-.30^{* *}$ & $.07^{*}$ & $.12^{* * *}$ & $.72^{* * * *}$ & $.39^{* * *}$ & $.30^{* * *}$ & $.20^{* * * *}$ & 1 & $.71^{* * *}$ \\
\hline 17. Ocjena II & $.15^{* * *}$ & .02 & $.38^{* * * *}$ & $.76^{* * *}$ & $.31^{* * *}$ & $.61^{* * *}$ & $.44^{* * *}$ & $.08^{* *}$ & $-.28^{* * *}$ & $.08^{*}$ & $.12^{* * *}$ & $.73^{* * *}$ & $.38^{* * *}$ & $.31^{* * *}$ & $.21^{* * *}$ & $.84^{* * *}$ & 1 \\
\hline
\end{tabular}

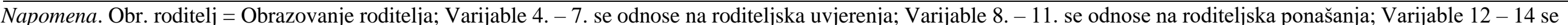

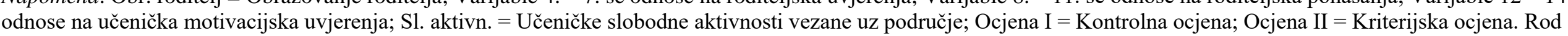
učenika je kodiran na način: dječaci $=1$; djevojčice $=2$.

$* * * p<.001 ; * * p<.01 ; * p<.05$. 
U pogledu povezanosti roditeljskih uvjerenja i ponašanja, potvrđene su očekivane veze između roditeljskih uvjerenja i roditeljskog poticanja interesa u matematici i tehničkoj kulturi te roditeljskog pribavljanja STEM materijala za dijete. Pozitivnija roditeljska uvjerenja specifična za dijete u matematici/tehničkoj kulturi povezana su s češćim roditeljskim poticanjem djetetovih interesa vezanih uz matematiku $(r=.11$ do $.21 ; p<.001)$ i tehničku kulturu $(r=.12$ do $.28 ; p<.001)$ te $\mathrm{s}$ većim pribavljanjem STEM materijala za dijete (matematika: $r=.07$ do $.20 ; p<.01$; tehnička kultura: $r=.10$ do $.22 ; p<.01$ ). Pozitivnija roditeljska uvjerenja su, u skladu s očekivanjima, povezana s rjeđom roditeljskom uključenosti $\mathrm{s}$ djetetom u aktivnosti vezane uz matematiku $(r=-.09$ do $-.36 ; p<.01)$. Međutim, u području tehničke kulture samo je roditeljska percepcija djetetove sposobnosti u ovom predmetu negativno povezana s roditeljskom uključenosti u aktivnosti vezane uz tehničku kulturu ( $r=$ $.13 ; p<.001$ ), dok je pozitivna korelacija pronađena između roditeljske uključenosti i roditeljske percepcije koristi tehničke kulture za dijete $(r=.13 ; p<.001)$ te roditeljske percepcije djetetovog truda u tehničkoj kulturi $(r=.12 ; p<.001)$.

Nadalje su pregledane korelacije koje se odnose na roditeljska ponašanja kao prediktore učeničkih obrazovnih ishoda. U skladu s očekivanjima, učenička motivacijska uvjerenja i frekvencija bavljenja slobodnim aktivnostima u matematičkom i tehničkom području pozitivno su povezani s roditeljskim poticanjem interesa u ovim područjima (matematika: $r=.13$ do .19 ; $p<.001$; tehnička kultura: $r=.10$ do $.34 ; p<.001$ ), roditeljskim modeliranjem aktivnosti u ovim područjima (matematika: $r=.07$ do $.11 ; p<.05$; tehnička kultura: $r=.11$ do $.13 ; p<.001$ ) te s roditeljskim pribavljanjem STEM materijala (matematika: $r=.11$ do $.17 ; p<.001$; tehnička kultura: $r=.08$ do $.21 ; p<.001)$. Također, kako je očekivano, roditeljska uključenost u dječje aktivnosti vezane uz matematiku je negativno povezana s učeničkim motivacijskim uvjerenjima u matematici $(r=-.07$ do $-.31 ; p<.05)$ i frekvencijom bavljenja slobodnim aktivnostima vezanim uz matematiku $(r=-.09 ; p<.01)$. Međutim, u području tehničke kulture, ovo je roditeljsko ponašanje slabo negativno povezano samo s učeničkom samoefikasnosti u tehničkoj kulturi $(r=-.07 ; p<.05)$, no pozitivno je povezano s učeničkim interesom za tehničku kulturu $(r=.12 ; p<.001)$ i važnosti koju učenik veže uz tehničku kulturu $(r=.15 ; p<.001)$, kao i s učeničkom frekvencijom bavljenja slobodnim aktivnostima vezanim uz tehničko područje $(r=$ $.08 ; p<.01)$.

Zatim su pregledane i korelacije između pojedinih učeničkih varijabli budući da su te veze dio širih medijacijskih hipoteza o neizravnom utjecaju roditeljskih varijabli na učeničke obrazovne ishode. Učeničko postignuće iz matematike na kraju šestog, odnosno sedmog razreda, pokazalo se pozitivno i umjereno do snažno povezano sa sve tri vrste učeničkih 
motivacijskih uvjerenja iz matematike, pri čemu je najsnažnija povezanost utvrđena $\mathrm{s}$ učeničkom samoefikasnosti u matematici (samoefikasnost: $r=.73 ; p<.001$; interes: $r=.38 ; p$ $<.001$; važnost: $r=.31 ; p<.001)$. S druge strane, u području tehničke kulture, utvrđena je samo povezanost između učeničkog postignuća u ovom predmetu i samoefikasnosti $(r=.29 ; p$ $<$.001), no nije utvrđena korelacija između učeničkog interesa za tehničku kulturu i važnosti tehničke kulture te postignuća u ovom predmetu. Motivacijska uvjerenja u matematici su se također, prema očekivanjima, pokazala pozitivno povezana s frekvencijom učeničkog bavljenja matematičkim aktivnostima, pri čemu je najveća korelacija utvrđena između učeničkog interesa za matematiku i bavljenja matematičkim aktivnostima (samoefikasnost: $r=.39 ; p<.001$; interes: $r=.50 ; p<.001$; važnost: $r=.37 ; p<.001)$. Isti obrazac povezanosti između motivacijskih uvjerenja i frekvencije bavljenja slobodnim aktivnostima utvrđen je i u području tehničke kulture (samoefikasnost: $r=.20 ; p<.001$; interes: $r=.32 ; p<.001$; važnost: $r=.28$; $p<.001)$.

\section{1. 3. Provjera preduvjeta za korištenje SEM analize}

Prije provede SEM analiza, potrebno je provjeriti statističke preduvjete nužne za valjano korištenje ovog postupka. Kline (2015) navodi nekoliko takvih pretpostavki. Najprije je važno provjeriti odsustvo ekstremnih slučajeva multikolinearnosti. Problem multikolinearnosti ukazuje da različite varijable zapravo mjere isti aspekt predmeta mjerenja, iz čega proizlazi da su pojedine varijable redundantne. Kao najjednostavnija metoda detekcije multikolinearnosti preporuča se izračun bivarijatnih korelacija između svih indikatora u SEM modelu. Bivarijatne korelacije koje prelaze vrijednost od .85 mogu ukazivati na potencijalni problem vezan uz kolinearnost (Kline, 2005). Stoga su za potrebe ovog istraživanja izračunate zasebne korelacije između svih indikatora u modelima za matematiku te zasebne korelacije između svih indikatora u modelima za tehničku kulturu ${ }^{20}$.

Korelacija viša od .85 pronađena je u slučaju dva indikatora na varijabli samoefikasnosti u matematici. Radi se o česticama: „Prema tvojem mišljenju, koliko si dobar/dobra u matematici?“ te „Kada bi trebao/la učenike svoga razreda poredati u matematici, od najlošijeg do najboljeg, gdje bi sebe stavio/stavila?“. Korelacija između ove dvije čestice iznosila je .86. Stoga smo odlučili prosjek vrijednosti na ove dvije čestice izraziti kao jednu varijablu. Tako je

\footnotetext{
${ }^{20}$ Detaljniji rezultati ove analize ne navode se u radu, no dostupni su na upit.
} 
u konačnom SEM modelu iz matematike latentni konstrukt učeničke samoefikasnosti umjesto pet imao četiri indikatora.

Nadalje, kako bismo utvrdili postoje li u podacima unvarijatne ekstremne vrijednosti, rezultati na svakoj varijabli transformirani su u z-vrijednosti te je potom provjereno prelaze li rezultati graničnu vrijednost od $z>3.29$ ili $z<-3.29$ (Field, 2009). Takva odstupanja su utvrđena na samo manjem broju učeničkih i roditeljskih varijabli te se radilo o relativno malom broju takvih rezultata na svakoj od pojedinih varijabli. Iz skupine varijabli koje se odnose na roditeljska uvjerenja, na varijabli "roditeljska percepcija korisnosti matematike za dijete" utvrđeno je 12 rezultata iznad granične z-vrijednosti (maksimalno odstupanje iznosilo je -4.20) te su utvrđena tek tri odstupajuća rezultata na varijabli "roditeljska percepcija djetetove sposobnosti u tehničkoj kulturi" (maksimalno odstupanje iznosilo je -3.52). U skupinama varijabli koje se odnose na roditeljska ponašanja, rezultati iznad apsolutne vrijednosti od $z=$ 3.29 utvrđeni su samo na varijabli "roditeljsko pribavljanje materijala". Na ovoj varijabli su utvrđena tri takva rezultata (maksimalno odstupanje iznosilo je -3.87).

U skupini varijabli koje se odnose na učenička motivacijska uvjerenja, u matematici su utvrđena odstupanja samo na jednom indikatoru konstrukta "učenička važnost matematike", gdje je bilo tek deset takvih slučajeva (maksimalno odstupanje iznosilo je -3.32). U tehničkoj kulturi ekstremni rezultati utvrđeni su na tri indikatora koja se odnose na varijablu "učenička samoefikasnost u tehničkoj kulturi". Na dva indikatora je utvrđeno osam takvih rezultata, a na jednom indikatoru 11 (maksimalno odstupanje iznosilo je -3.75). Na varijablama koje se odnose na učeničke slobodne aktivnosti, ni u matematici ni u tehničkoj kulturi nije bilo odstupajućih rezultata. U ocjenama iz matematike nisu utvrđeni odstupajući rezultati, dok su na kontrolnoj ocijeni iz tehničke kulture utvrđena dvije takve vrijednosti (-4.20), a na kriterijskoj ocijeni iz tehničke kulture četiri takve vrijednosti. S obzirom da su te četiri vrijednosti bile bitno iznad $z$ graničnog praga $(<-4.50)$, odlučeno je da ove vrijednosti budu uklonjene iz daljnje analize. $\mathrm{Na}$ svim ostalim varijablama odstupajući univarijatni rezultati su zadržani u daljnjoj analizi. Naime, kod velikih uzorka, kao što je slučaj u ovom istraživanju, uobičajeno je pojavljivanje manjeg broja odstupajućih rezultata (Tabachnick i Fidell, 2013). Pored toga, na većini varijabli utvrđena odstupanja nisu bila bitno veća od apsolutne vrijednosti $z=3.29$.

U svrhu detekcije multivarijatnih ekstremnih rezultata, izračunate su Mahalanobis distance pomoću regresijskog modela u kojem su sve varijable iz pojedinog SEM modela korištene kao prediktori, dok je kao kriterijska varijabla korišten jedinstveni identifikacijski broj učenika (Tabachnick i Fidell, 2007). Pri ovoj se metodi kao granična vrijednost Mahalanobis distance uzima granična vrijednost hi-kvadrat distribucije uz razinu značajnosti 
od .001 te uz broj stupnjeva slobode koji odgovara broju prediktora u regresijskom modelu ${ }^{21}$ (Tabachnick i Fidell, 2007). Ovom je metodom utvrđeno između 14 i 20 odstupajućih multivarijatnih rezultata, ovisno o varijablama iz pojedinog SEM modela. Kako bi se minimizirao broj sudionika koji su zbog multivarijatnih ekstremnih rezultata isključeni iz daljnjih analiza, formirano je šest novih baza podataka za šest SEM modela koji su ispitani u glavnoj analizi (dva predmeta $\times$ tri vrste učeničkih motivacijskih uvjerenja). Iz svake od ovih baza isključeni su samo oni sudionici koji su imali multivarijatne ekstremne rezultate na kombinaciji varijabli koje čine pojedini SEM model.

Tako je naposljetku za ispitivanje modela $\mathrm{u}$ matematici $\mathrm{s}$ varijablom učeničke samoefikasnosti izbačeno 16 sudionika (konačni $N=1048$ ), za model s varijablom učeničkog interesa za matematiku 14 sudionika (konačni $N=1050$ ) te za model s varijablom učeničke važnosti matematike 14 sudionika (konačni $N=1050$ ). U modelu s učeničkom samoefikasnosti u tehničkoj kulturi izbačeno je 20 sudionika (konačni $N=1044$ ), u modelu s učeničkim interesom za tehničku kulturu 16 sudionika (konačni $N=1048$ ) te u modelu s učeničkom važnosti tehničke kulture 14 sudionika (konačni $N=1050$ ).

Zatim su pregledane univarijatne distribucije svih varijabli, uvidom $\mathrm{u}$ histograme rezultata $^{22}$. Pokazalo se da su distribucije rezultata na svim varijablama roditeljskih uvjerenja specifičnih za dijete i u matematici i tehničkoj kulturi negativno asimetrične, s koncentracijom većine roditeljskih rezultata u višim vrijednostima. Među varijablama koje se odnose na roditeljska ponašanja, rezultati na indikatorima roditeljskog modeliranja matematičkih aktivnosti su normalno distribuirani, dok su distribucije dva od ukupno tri indikatora roditeljskog modeliranja tehničkih aktivnosti blago pozitivno asimetrične, s koncentracijom rezultata u nižim vrijednostima. Rezultati na većini indikatora roditeljske uključenosti u predmet su normalno distribuirani, izuzev dvije čestice u području tehničke kulture koje se odnose na roditeljsko pomaganje s domaćom zadaćom i pomaganje u učenju za testove $\mathrm{i}$ ispitivanja, na kojima rezultati imaju pozitivno asimetričnu distribuciju, što ukazuje da većina roditelja provodi ovaj oblik aktivnosti relativno rijetko. Rezultati na većini indikatora koji se odnose na roditeljsko poticanje interesa u području matematike i tehničke kulture su normalno

\footnotetext{
${ }^{21}$ U slučaju varijabli koje čine SEM modele iz matematike, broj stupnjeva slobode u regresijskom modelu iznosio je 23. U slučaju varijabli koje čine SEM modele iz tehničke kulture broj stupnjeva slobode u regresijskom modelu iznosio je 27 za model s varijablom učeničke samoefikasnosti te 26 za model s varijablom učeničkog interesa te za model s varijablom učeničke važnosti tehničke kulture. U ove regresijske modele nisu unesene varijable učeničkog spola i dobne kohorte.

${ }^{22}$ Kod velikih uzoraka, kao što je slučaj u ovom istraživanju, formalni testovi pristajanja rezultata normalnoj distribuciji često dovode do pogrešnog odbacivanja nul-hipoteze. Stoga je provjera oblika distribucije u slučajevima velikih uzoraka bolji način utvrđivanja normalnosti distribucije (Tabachnick i Fidell, 2013).
} 
distribuirani, izuzev jednog indikatora u području matematike i jednog indikatora u području tehničkih aktivnosti, na kojima su uočene blago negativno asimetrične distribucije. Rezultati na varijabli roditeljskog pribavljanja materijala vezanih uz matematiku i tehničku kulturu pokazuju pozitivno asimetričnu distribuciju, s koncentracijom rezultata u nižim vrijednostima.

Nadalje su pregledani indikatori učeničkih motivacijskih uvjerenja. Na konstruktu učeničke samoefikasnosti u matematici, od četiri indikatora ovog konstrukta, na dva je uočena blago negativno asimetrična distribucija, dok je na ostala dva indikatora distribucija rezultata normalna. S druge strane, u tehničkoj kulturi je na svim indikatorima učeničke samoefikasnosti zapažena negativno asimetrična distribucija, što pokazuje da većina učenika izvještava o samoefikasnosti u tehničkoj kulturi koja je iznad srednje vrijednosti skale odgovora.

Na svim indikatorima učeničkog interesa za predmet i u matematici i tehničkoj kulturi zabilježene su normalne distribucije. S druge strane, distribucije svih indikatora učeničke percepcije važnosti matematike pomaknute su u desno, s koncentracijom rezultata u višim vrijednostima. U tehničkoj kulturi su pak svi indikatori važnosti predmeta distribuirani normalno.

$\mathrm{Na}$ indikatorima učeničkih slobodnih aktivnosti vezanih uz matematiku i tehničku kulturu, većina je distribucija rezultata blago pomaknuta prema nižim vrijednostima, što ukazuje na nešto rjeđe učeničko bavljenje s ovim aktivnostima. Naposljetku, u pogledu učeničkih ocjena, uočene su blago negativno asimetrične distribucije ocjena iz matematike te izrazito negativno asimetrične distribucije ocjena iz tehničke kulture.

Rezultati Mardia testa unutar 'MVN' funkcije ${ }^{23}$ istoimenog R-ovog paketa, pokazali su značajna odstupanje od multivarijatne normalne distribucije u slučaju skupa varijabli iz svih šest SEM modela. Prikaz rezultata ovog testa za sve modele nalazi se u Prilogu 3. Budući da je utvrđen izostanak multivarijatne te dijelom unvarijatne normalnosti podataka, odlučeno je da umjesto standardne 'maximum likelihood $(M L)$ ' metode procjene parametara unutar SEM modela bude korištena 'MLR' metoda. MLR predstavlja robusnu varijantu ML metode koja korigira pristranost standardnih pogrešaka koja se može javiti kao posljedica nezadovoljavanja uvjeta o normalnoj distribuciji rezultata u SEM modelima (Brown, 2015).

Nadalje, kako bi SEM modeli mogli biti identificirani, nužno je da broj slobodnih parametara koje procjenjujemo bude manji od broja elemenata ulazne matrice varijanci i kovarijanci (Brown, 2015). Primjenom formule $a=p(p+1) / 2$ (pri čemu je 'a' ukupan broj ulaznih elemenata, a 'p' broj manifestnih indikatora), dobije se da je u sva tri modela iz

\footnotetext{
${ }^{23}$ Kako bi se unutar 'MVN' paketa mogle dobiti vrijednosti Mardia testa, potrebno je koristiti podatkovnu bazu bez nedostajućih vrijednosti (Korkmaz, Goksuluk, Zararsiz i Korkmaz, 2019).
} 
matematike broj ulaznih elemenata jednak 325 s obzirom da je sva tri modela ukupno 25 varijabli. U modelima iz matematike procjenjujemo ukupno 75 do $77^{24}$ parametara: u mjernom modelu šest kovarijanci između varijabli roditeljskih ponašanja, šest varijanci faktora, 19 varijanci mjernih pogrešaka i 13 faktorskih saturacija ${ }^{25}$, a u strukturalnim modelima ukupno 31 do 33 strukturalna puta. Tako u modelima iz matematike imamo ukupno 250 do 248 stupnjeva slobode, čime su svi modeli preidentificirani.

Zbog većeg broja manifestnih indikatora, u modelima iz tehničke kulture broj ulaznih elemenata je nešto veći i iznosi 329 u slučaju modela s varijablom učeničke samoefikasnosti te 328 u modelima s varijablom učeničkog interesa i važnosti. Za većinu vrsti parametara broj procijenjenih parametara je isti kao u modelima iz matematike, izuzev što u modelima iz tehničke kulture, zbog većeg broja indikatora, procjenjujemo 23 varijance mjernih pogrešaka i 17 faktorskih saturacija u modelu s varijablom učeničke samoefikasnosti te 22 varijance mjernih pogrešaka i 16 faktorskih saturacija u modelima s varijablom učeničkog interesa i važnosti. U modelu sa samoefikasnosti iz tehničke kulture procjenjujemo 36 strukturalnih parametara, a u modelima s interesom i važnosti tehničke kulture po 32 strukturalna parametra. Tako je u modelu s učeničkom samoefikasnosti u tehničkoj kulturi ukupno 88 procijenjenih parametara i 241 stupanj slobode, dok je u modelima s učeničkim interesom i važnosti tehničke kulture ukupno 82 procijenjena parametra i 246 stupnjeva slobode. Time su svi modeli iz tehničke kulture također preidentificirani ${ }^{26}$.

Naposljetku, slijedeći opću preporuku o postojanju deset opservacija za svaki procijenjeni parametar (Joreskog i Sorbom, 1989), možemo zaključiti da je u svih šest SEM modela uključen dovoljan broj sudionika za opravdano provođenje SEM analize.

\footnotetext{
${ }^{24} \mathrm{U}$ sva tri modela iz matematike broj procijenjenih parametara u mjernom modelu je isti i iznosi 44 . Broj strukturalnih parametara se razlikuje s obzirom na definirane puteve između učeničkih kontrolnih varijabli (rod i razred učenika te prošlo postignuće u predmetu) $i$ endogenih varijabli u modelu. Ovi su putevi definirani uvidom u značajne bivarijatne korelacije između kontrolnih varijabli i ostalih učeničkih i roditeljskih varijabli. Zbog istog razloga, razlikovanja u broju strukturalnih parametara postoje i u modelima u tehničkoj kulturi.

${ }^{25}$ Šest saturacija smo fiksirali na jedan radi dodjeljivanja mjerene skale latentnim varijablama (vidi Brown, 2015). Isto vrijedi i za modele u području tehničke kulture.

${ }^{26} \mathrm{~S}$ obzirom na post-hoc respecifikacije mjernih i strukturalnih modela koje su opisane u poglavljima 4.2.1. i 4.2.2., konačni brojevi procijenjenih parametara i stupnjeva slobode u manjoj se mjeri razlikuju od ovih inicijalnih procjena, no svih šest završnih SEM modela su i nakon ovih respecifikacija preidentificirani.
} 


\section{2. Provjera modela roditeljskih odrednica učeničkih obrazovnih ishoda u matematici i tehničkoj kulturi}

4. 2. 1. Provjera mjernih dijelova modela roditeljskih odrednica učeničkih obrazovnih ishoda u matematici i tehničkoj kulturi

U ovom su poglavlju prikazani rezultati CFA analiza za svih šest mjernih modela $u$ području matematike i tehničke kulture (tri modela koja su testirana u dva predmeta - model s učeničkom samoefikasnosti u predmetu, model s učeničkim interesom za predmet i model s učeničkom važnosti predmeta). Početni mjerni model iz matematike s varijablom učeničke samoefikasnosti imao je većim dijelom zadovoljavajuće indekse pristajanja: Yuan-Bentler $\chi^{2}$ $(137)=750.59, p<.001 ; \chi^{2} / d f=5.48 ; \mathrm{R}-\mathrm{CFI}=.94 ; \mathrm{R}-\mathrm{TLI}=.93 ; \mathrm{R}-\mathrm{RMSEA}=.067,90 \% \mathrm{CI}$ $[.062, .072]$; SRMR $=.064$. Međutim, kako bismo pokušali poboljšati pristajanje modela podacima, pregledani su tzv. modifikacijski indeksi. Ovi indeksi pokazuju u kojoj bi se mjeri pristajanje modela poboljšalo u slučaju oslobađanja pojedinih parametara (Brown, 2015). Modifikacijski indeksi su ukazali na dva potencijalna poboljšanja u modelu. Prvi po veličini modifikacijski indeks sugerirao je uvođenje kovarijance između mjernih pogrešaka dva indikatora koja se odnose na roditeljska uvjerenja specifična za dijete u matematici. Riječ je o česticama: „Koliko Vaše dijete pokazuje interesa za matematiku?““ i „Koliko se Vaše dijete trudi oko matematike?“. Vrijednost modifikacijskog indeksa za ovaj parametar pokazala je da bi se uvođenjem slobodne procjene ovog parametra $\chi^{2}$ za ukupni model smanjio za 125.39 jedinica. Kovarijanca pogrešaka između ova dva indikatora ukazuje da oni mjere nešto što je jedinstveno za njih, a ne može se objasniti njihovim latentnim faktorom (Kline, 2015). Iz ovog smo razloga odlučili ove dvije čestice kombinirati u jedan kompozit. Stoga je u svim modelima iz matematike u konačnici faktor roditeljskih uvjerenja umjesto četiri, imao tri manifestna indikatora.

Nadalje, drugi i četvrti modifikacijski indeks ukazao je na problem s jednim od indikatora roditeljske uključenosti u djetetove aktivnosti vezane uz matematiku - „Razgovaram s djetetom o onome što uči na satovima matematike." Ovi su indeksi ukazivali na značajno smanjivanje hi-kvadrata u slučaju uvođenja križnih saturacija ovog indikatora s faktorima roditeljskog modeliranja matematičkih aktivnosti i roditeljskog poticanja djetetovih interesa $u$ području matematike. I sa sadržajne strane ova čestica odudara od ostala dva indikatora roditeljske uključenosti koja se odnose na roditeljsko pomaganje u obavezama iz matematike pomaganje u pisanju zadaća i u učenju za provjere znanja i za usmena ispitivanja. Stoga smo 
odlučili ovu česticu isključiti iz mjernih modela u matematici, čime su svi modeli iz matematike umjesto tri imali dva indikatora faktora roditeljske uključenosti.

Nakon uvođenja dvije opisane modifikacije, mjerni model s varijablom učeničke samoefikasnosti u matematici imao je prihvatljive do dobre indekse pristajanja podacima (Tablica 5).

Model s učeničkim interesom za matematiku također je na većini indeksa pristajanja imao zadovoljavajuće do dobro pristajanje podacima (Tablica 5). Inicijalni model s važnosti matematike imao je prihvatljive, ali ipak nešto lošije indekse pristajanja: Yuan-Bentler $\chi^{2}(104)$ $=672.75, p<.001 ; \chi^{2} / d f=6.47 ; \mathrm{R}-\mathrm{CFI}=.91 ; \mathrm{R}-\mathrm{TLI}=.88 ; \mathrm{R}-\mathrm{RMSEA}=.073,90 \% \mathrm{CI}[.068$, $.079] ;$ SRMR $=.050$. Prvi po veličini modifikacijski indeks sugerirao je oslobađanje kovarijance mjernih pogrešaka dva indikatora konstrukta važnosti matematike koji se odnose na percipiranu korisnost predmeta što bi smanjilo hi-kvadrat vrijednost za 162.81 jedinice. Uvođenje kovarijance između pogrešaka $u$ modelu iziskuje osim statističke i teorijsku, odnosno, istraživačku elaboraciju (Brown, 2015). Činjenica da se ove dvije čestice jedine u konstruktu važnosti odnose na percepciju korisnosti predmeta predstavlja i teorijsko opravdanje za oslobađanje kovarijance njihovih pogrešaka. Nakon uvođenja ove modifikacije, model je pokazao prihvatljivo do dobro pristajanje podacima (Tablica 5).

Tablica 5. Indeksi pristajanje mjernih modela u području matematike i tehničke kulture

\begin{tabular}{cccccccc}
\hline Model & YB $\chi^{2}$ & $d f$ & $\chi^{2} / d f$ & $\begin{array}{c}\text { R- } \\
\text { CFI }\end{array}$ & R-TLI & $\begin{array}{c}\text { R-RMSEA } \\
(90 \% \text { CI })\end{array}$ & SRMR \\
\hline Matematika & & & & & & & \\
\hline Samoefikasnost & 410.95 & 104 & 3.95 & .97 & .96 & $.054(.049-.060)$ & .046 \\
Interes & 472.76 & 104 & 4.55 & .96 & .94 & $.059(.054-.065)$ & .046 \\
Važnost & 524.65 & 103 & 5.09 & .94 & .92 & $.063(.058-.069)$ & .047 \\
\hline Tehnička kultura & & & & & & & \\
\hline Samoefikasnost & 770.53 & 193 & 3.99 & .94 & .93 & $.054(.050-.058)$ & .049 \\
Interes & 677.95 & 173 & 3.92 & .94 & .93 & $.054(.049-.058)$ & .049 \\
Važnost & 771.16 & 172 & 4.48 & .93 & .91 & $.058(.054-.062)$ & .051 \\
\hline
\end{tabular}

U tablici u Prilogu 4 prikazana su faktorska zasićenja za sve indikatore korištene u modelima iz matematike i tehničke kulture. Prosjek prikazanih faktorskih zasićenja za indikatore u području matematike iznosi .77. Sva faktorska zasićenja u konačnim mjernim modelima iz matematike bila su značajna i na većini faktora viša od .60. Izuzetak je jedan od 
indikatora roditeljskih uvjerenja koji se odnosi na roditeljsku percepciju korisnosti predmeta za dijete čije je zasićenje bilo nešto niže te je iznosilo između .41 i .45, ovisno o modelu.

Nadalje su provjereni modeli u području tehničke kulture. Inicijalni model s učeničkom samoefikasnosti iz tehničke kulture imao je sljedeće indekse pristajanja: Yuan-Bentler $\chi^{2}(215)$ $=1090.13, p<.001 ; \chi^{2} / d f=5.07 ; \mathrm{R}-\mathrm{CFI}=.91 ; \mathrm{R}-\mathrm{TLI}=.90 ; \mathrm{R}-\mathrm{RMSEA}=.063,90 \%$ CI $[.060$, $.067]$; SRMR $=.060$. Kako bismo poboljšali pristajanje modela, pregledani su modifikacijski indeksi. Prvi po veličini indeks ukazivao je na oslobađanje mjerne pogreške između indikatora roditeljskog modeliranja: „Koliko često Vi sami kod kuće ili u slobodno vrijeme slažete Lego kocke ili puzzle?“ $\mathrm{i}$ indikatora roditeljskog poticanja djetetovih interesa: „Koliko često potičete dijete da slaže Lego kocke ili puzzle?“. Uvođenje kovarijanci između mjernih pogrešaka indikatora različitih faktora koji imaju isti širi kontekst ili sadržaj smatra se opravdanim u složenim SEM modelima (Little, 2013). Nadalje, kao i u slučaju modela iz matematike, i u modelu iz tehničke kulture je indikator roditeljske uključenosti koji se odnosi na čestinu roditeljskog razgovaranja s djetetom o sadržajima koje uči iz predmeta pokazivao značajne križne saturacije s drugim roditeljskim konstruktima. Stoga je ovaj indikator isključen i iz svih modela iz tehničke kulture. Nakon ove dvije modifikacije model s varijablom učeničke samoefikasnosti iz tehničke kulture imao je bolje pristajanje podacima po svim indeksima pristajanja (Tablica 5).

Model s učeničkim interesom za tehničku kulturu imao je prihvatljive do dobre indekse pristajanja (Tablica 5). Inicijalni model s važnosti tehničke kulture imao je relativno loše indekse pristajanja: Yuan-Bentler $\chi^{2}(194)=1227.85, p<.001 ; \chi^{2} / d f=6.33 ; \mathrm{R}-\mathrm{CFI}=.88$; R$\mathrm{TLI}=.86 ; \mathrm{R}-\mathrm{RMSEA}=.072,90 \%$ CI $[.068, .076] ;$ SRMR $=.064$. Modifikacijski indeksi pokazali su značajno poboljšanje pristajanja modela u slučaju oslobađanja kovarijance mjernih pogrešaka dva indikatora koji se odnose na percepciju važnosti tehničke kulture u užem smislu te kovarijance dva indikatora koji se odnose na percepciju korisnosti tehničke kulture unutar šireg latentnog faktora važnosti. Uzimajući u obzir teorijsku i sadržajnu opravdanost ovih kovarijanci, obje su uvedene u model. Nakon ovih modifikacija, model je imao prihvatljivo pristajanje podacima (Tablica 5).

Sva faktorska zasićenja u mjernim modelima iz tehničke kulture su značajna i većina ih je viša od .50, dok prosječno faktorsko zasićenje iznosi .74 (Prilog 4). Pregledom korelacija između latentnih konstrukata u mjernim modelima iz oba predmeta, utvrđeno je da nijedna nije prelazila vrijednost od .85 (Prilog 5). 
4. 2. 2. Procjena izravnih puteva u strukturalnim modelima roditeljskih odrednica učeničkih obrazovnih ishoda u matematici

Nakon što smo utvrdili da svi mjerni modeli imaju adekvatno pristajanje podacima, izračunati su pretpostavljeni izravni putevi u strukturalnom dijelu SEM modela. Svi putevi su specificirani na osnovi istraživačkih hipoteza prikazanih u poglavlju 2.1 (hipoteze 1a, 2a, 2b, 2c, 3a). Veze između kontrolnih varijabli (učeničkog roda, razreda, prošlog postignuća te obrazovanja roditelja) i svih ostalih endogenih varijabli u modelu postavljene su na temelju pregleda značajnosti bivarijatnih korelacija između pojedinih parova varijabli. Budući da se pokazalo da roditeljsko modeliranje matematičkih aktivnosti nije bilo značajan prediktor nijednog učeničkog obrazovnog ishoda ni u jednom od tri modela s učeničkim motivacijskim uvjerenjima u matematici, a modelom nije predviđeno da ovo ponašanje ima medijacijsku ulogu pri djelovanju drugih roditeljskih utjecaja (obrazovanja roditela i roditeljskih uvjerenja), ova je varijabla isključena iz analiza modela u matematici. Svi indikatori pristajanja strukturalnih modela u matematici se stoga odnose na modele bez ove latentne varijable.

Osim regresijskih puteva, u svakom su modelu također specificirane tri kovarijance između rezidualnih varijanci preostala tri roditeljska ponašanja u matematici. Nakon inspekcije inicijalnog strukturalnog modela, metodom rezanja modela, koja je opisana u potpoglavlju 3. 4. 3., statistički neznačajni strukturalni putevi su fiksirani na nulu u svrhu postavljanja što jednostavnijih modela.

Početni strukturalni model s varijablom učeničke samoefikasnosti u matematici imao je vrlo dobre indekse pristajanja: Yuan-Bentler $\chi^{2}(155)=455.73, p<.001 ; \chi^{2} / d f=2.94$; R-CFI $=.97 ; \mathrm{R}-\mathrm{TLI}=.96 ; \mathrm{R}-\mathrm{RMSEA}=.044,90 \%$ CI $[.040, .049] ;$ SRMR $=.039 . \mathrm{U}$ ovom je modelu bilo ukupno deset neznačajnih regresijskih puteva koji su fiksirani na nulu, nakon čega je model i dalje imao dobro pristajanje podacima koje nije bilo statistički značajno lošije od pristajanja punog modela: $\Delta \mathrm{YB} \chi^{2}(10)=12.52, p=.252$. U jednostavnijem modelu još je jedan regresijski put bio statistički neznačajan te je fiksiran na nulu nakon čega su dva modela uspoređena. Uklanjanje ovog puta nije pogoršalo model: $\Delta \mathrm{YB} \chi^{2}(1)=3.63, p=.057$. U konačnom su modelu svi zadržani putevi bili statistički značajni te je model imao dobre indekse pristajanja (Tablica 6).

Početni strukturalni model s varijablom učeničkog interesa za matematiku imao je također vrlo dobre indekse pristajanja: Yuan-Bentler $\chi^{2}(154)=491.71, p<.001 ; \chi^{2} / d f=3.19$; $\mathrm{R}-\mathrm{CFI}=.97 ; \mathrm{R}-\mathrm{TLI}=.95 ; \mathrm{R}-\mathrm{RMSEA}=.047,90 \%$ CI $[.042, .052] ;$ SRMR $=.042 . \mathrm{I}$ u slučaju ovog modela, fiksiranje na nulu 12 neznačajnih puteva nije dovelo do lošijeg pristajanja modela 
podacima: $\Delta \mathrm{YB} \chi^{2}(12)=10.15, p=.603$. U jednostavnijem modelu je još jedan put bio statistički neznačajan. Fiksiranje ovog puta na nulu nije dovelo do značajnog pogoršanja modela: $\Delta \mathrm{YB} \chi^{2}(1)=3.62, p=.057$. Inspekcijom modela nakon drugog ,rezanja“ je utvrđeno da je još jedan put neznačajan te je i on fiksiran na nulu čime se pristajanje modela ponovno nije pogoršalo: $\Delta \mathrm{YB} \chi^{2}(1)=2.23, p=.135$. Ovaj završni model, u kojem su svi zadržani putevi bili statistički značajni, imao je dobro pristajanje podacima (Tablica 6).

Naposljetku, strukturalni model s varijablom učeničke važnosti matematike imao je prihvatljive do dobre indikatore pristajanja: Yuan-Bentler $\chi^{2}(152)=581.42, p<.001 ; \chi^{2} / d f=$ 3.83; R-CFI = .95; R-TLI = .93; R-RMSEA = .053, 90\% CI [.049, .058]; SRMR = .045. Nakon što je 14 neznačajnih puteva fiksirano na nulu pristajanje modela nije bilo lošije u odnosu na inicijalni model: $\Delta \mathrm{YB} \chi^{2}(14)=15.30, p=.358$. U jednostavnijem je modelu još jedan put bio statistički neznačajan. Fiksiranje ovog puteva na nulu nije dovelo do značajnog pogoršanja modela: $\Delta \mathrm{YB} \chi^{2}(1)=3.60, p=.058$. Konačan model imao je dobre indekse pristajanja (Tablica $6)$.

Tablica 6. Indeksi pristajanja strukturalnih modela roditeljskih odrednica učeničkih obrazovnih ishoda u području matematike nakon što su neznačajni putevi fiksirani na nulu

\begin{tabular}{cccccccc}
\hline Model & YB $\chi^{2}$ & $d f$ & $\chi^{2} / d f$ & $\begin{array}{c}\text { R- } \\
\text { CFI }\end{array}$ & R-TLI & $\begin{array}{c}\text { R-RMSEA } \\
(90 \% \text { CI })\end{array}$ & SRMR \\
\hline Samoefikasnost & 471.26 & 166 & 2.84 & .97 & .97 & $.043(.039-.048)$ & .040 \\
Interes & 506.81 & 168 & 3.02 & .97 & .96 & $.045(.041-.050)$ & .043 \\
Važnost & 619.11 & 167 & 3.71 & .95 & .93 & $.052(.048-.057)$ & .046 \\
\hline
\end{tabular}

U Prilogu 6 prikazane su standardizirane vrijednosti za sve izračunate direktne učinke u sva tri strukturalna modela iz matematike. Slike 7, 8 i 9 prikazuju dobivene regresijske koeficijente za izravne puteve koji su specificirani prvom, drugom i trećom skupinom istraživačkih hipoteza ${ }^{27}$. Putevi koji su pretpostavljeni istraživačkom hipotezom, ali su bili statistički neznačajni u sva tri modela s učeničkim motivacijskim uvjerenjima, iscrtani su isprekidanom linijom. Radi jednostavnosti, na slikama nije prikazan mjerni dio modela, kao ni korelacije između varijabli roditeljskih ponašanja. Na isti su način prikazani i modeli iz tehničke kulture u sljedećem potpoglavlju.

\footnotetext{
${ }^{27}$ Prikazani koeficijenti su izračunati na temelju punog strukturalnog modela (uz kontrolu svih ostalih puteva koji su postavljeni u konačnom modelu). No, zbog jednostavnosti prikaza rezultata, na slikama su samo oni dijelovi modela koji prikazuju izravne puteve koji su dio tri skupine istraživačkih hipoteza.
} 
Kao što je vidljivo iz Slike 7, u kontekstu prve skupine istraživačkih hipoteza, pokazalo se da je više obrazovanje roditelja jedino u manjoj mjeri povezano $\mathrm{s}$ većim roditeljskim pribavljanjem materijala za dijete u STEM području $(\beta=.11 ; p<.001)$. Nakon kontrole učeničkog prethodnog postignuća iz matematike, obrazovanje roditelja nije bilo povezano $\mathrm{s}$ roditeljskim uvjerenjima specifičnim za dijete u matematici, kao ni s razinom poticanja djetetovih interesa za matematičke aktivnosti.

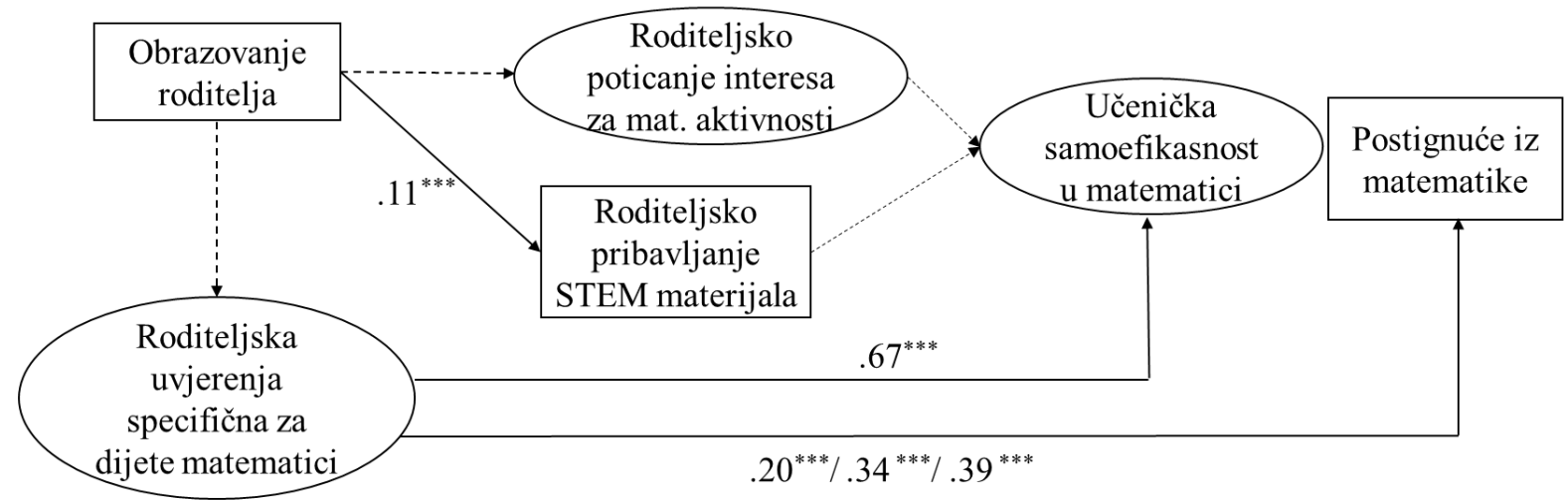

Slika 7. Izravni standardizirani regresijski učinci koji su dio istraživačkih hipoteza prve skupine. Prva vrijednost koeficijenta se odnosi na model s učeničkom samoefikasnosti, druga na model $\mathrm{s}$ učeničkim interesom, a treća vrijednost na model s učeničkom važnosti matematike. Isprekidanom linijom su prikazani putevi koji su bili neznačajni u sva tri modela (modelu sa samoefikasnosti, interesom i važnosti). $* * * p<.001$.

Kao što je vidljivo iz Slike 8, u skladu s očekivanjima, više prošlo učeničko postignuće iz matematike predviđalo je pozitivnija roditeljska uvjerenja specifična za dijete u matematici te se radi o velikom učinku: $\beta=.82-.84 ; p<.001$. Nadalje, u skladu s hipotezama druge skupine, roditeljska uvjerenja pozitivno su predviđala učeničku samoefikasnost $(\beta=.67 ; p<$ $.001)$, interes $(\beta=.45 ; p<.001)$ i važnost matematike $(\beta=.44 ; p<.001)$. Učeničku samoefikasnost (ali ne i učenički interes i važnost matematike) pozitivno je predviđalo i učeničko prethodno postignuće iz matematike $(\beta=.21 ; p<.001)$. Također, od svih učeničkih motivacijskih uvjerenja, jedino je učenička samoefikasnost u matematici predviđala kasnije postignuće u matematici $(\beta=.29 ; p<.001)$. 


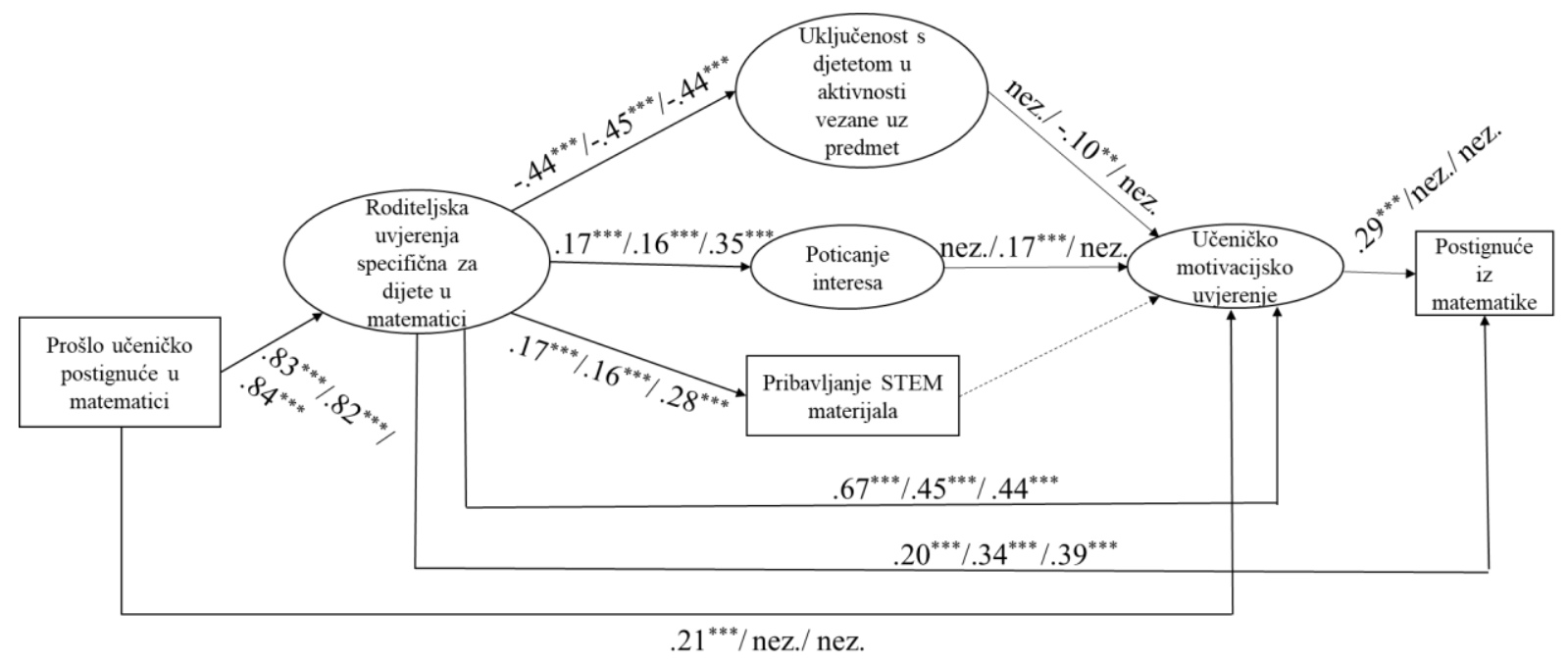

Slika 8. Izravni standardizirani regresijski učinci koji su dio istraživačkih hipoteza druge skupine Prva vrijednost koeficijenta se odnosi na model s učeničkom samoefikasnosti, druga na model s učeničkim interesom, a treća vrijednost na model s učeničkom važnosti matematike. nez. $=$ put je u početnom modelu bio statistički neznačajan te je stoga u konačnom modelu fiksiran na nulu. Isprekidanom linijom je prikazan put koji je bio neznačajan u sva tri modela (modelu sa samoefikasnosti, interesom i važnosti).

$* * p<.01 ; * * * p<.001$.

U sva tri modela, roditeljska uvjerenja su predviđala ne samo učenička motivacijska uvjerenja, već i kasnije učeničko postignuće iz matematike $(\beta=.20-.39 ; p<.001)$. Prema očekivanjima, roditeljska uvjerenja su predviđala i tri vrste roditeljskih ponašanja vezanih uz matematiku i STEM. Roditeljska uvjerenja o višim djetetovim sposobnostima, interesu, trudu u matematici i korisnosti matematike za dijete predviđala su češće poticanje djetetovih interesa za matematiku $(\beta=.17-.35 ; p<.001)$ te veće roditeljsko pribavljanje STEM materijala za dijete $(\beta=.16-.28 ; p<.001)$. S druge strane, kao što je očekivano, roditeljska uvjerenja o nižim djetetovim sposobnostima, interesu, trudu u matematici i korisnosti matematike za dijete bila su povezana s češćom uključenosti roditelja u djetetove obaveze iz matematike $(\beta=-.44-$ $-.45 ; p<.001)$.

Međutim, roditeljska ponašanja u većini slučajeva nisu predviđala učenička motivacijska uvjerenja. Izuzetak je učenički interes za matematiku kojeg je pozitivno predviđalo roditeljsko poticanje interesa u matematici $(\beta=.17 ; p<.001)$, dok je roditeljska uključenost u djetetove obaveze iz matematike negativno predviđala učenički interes za ovaj predmet $(\beta=-.10 ; p=.005)$.

Slika 9 prikazuje izravne puteve koji su specificirani hipotezama treće skupine. Roditeljsko pribavljanje STEM materijala nije prikazano na slici budući da ovo ponašanje ni u jednom od modela nije predviđalo nijedan oblik učeničkih obrazovnih ishoda u matematici. 
Kao što je već opisano u prethodnom odlomku, od učeničkih motivacijskih uvjerenja u matematici, samo je učenički interes za matematiku bio povezan s nekim od roditeljskih ponašanja u matematičkom području.

Frekvenciju učeničkog bavljenja slobodnim aktivnostima u matematičkom području pozitivno je predviđalo roditeljsko poticanje djetetovih interesa za matematiku $(\beta=.11-.23$; $p<.01$ ), dok je roditeljska uključenost $\mathrm{u}$ djetetove matematičke obaveze $\mathrm{u}$ dva modela negativno predviđala učeničko bavljenje matematičkim aktivnostima u slobodno vrijeme $(\beta=$ -.08; -.14; $p<.05)$. U skladu s hipotezom, sva tri motivacijska uvjerenja učenika u matematici - samoefikasnost $(\beta=.59 ; p<.001)$, interes $(\beta=.55 ; p<.001)$ i važnost matematike $(\beta=.42$; $p<.001)$ pozitivno su predviđala frekvenciju učeničkog bavljenja matematičkim aktivnostima.

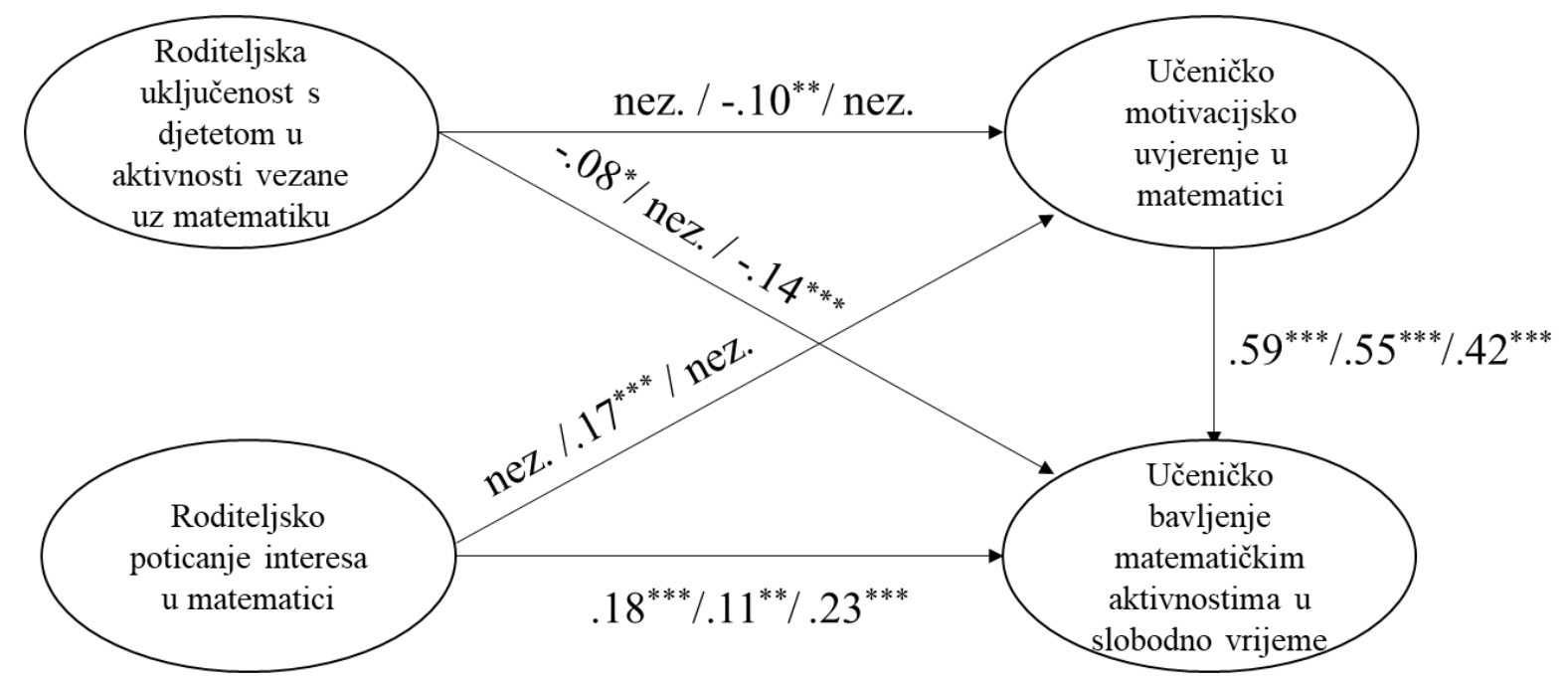

Slika 9. Izravni standardizirani regresijski učinci koji su dio istraživačkih hipoteza treće skupine. Prva vrijednost koeficijenta se odnosi na model s učeničkom samoefikasnosti, druga na model s učeničkim interesom, a treća vrijednost na model s učeničkom važnosti matematike. nez. $=$ put je u početnom modelu bio statistički neznačajan te je stoga u konačnom modelu fiksiran na nulu.

$* p<.05 ; * * p<.01 ; * * * p<.001$.

Iako taj odnos nije obuhvaćen nekom od istraživačkih hipoteza, konceptualnim modelom je postavljeno da će frekvencija učeničkog bavljenja matematičkim aktivnostima pozitivno predviđati učeničko postignuće iz matematike. Ovaj je put bio neznačajan u modelu s interesom i važnosti, ali značajan u modelu s učeničkom samoefikasnosti u kojem je češće bavljenje matematičkim aktivnostima u slobodno vrijeme negativno predviđalo učeničko postignuće iz matematike, iako je taj efekt bio vrlo mali: $\beta=-.08 ; p<.001$ (Prilog 6). 
Kada govorimo o kontrolnim varijablama, roditelji dječaka su imali pozitivnija uvjerenja specifična za dijete u matematici $(\beta=-.07 ; p<.001)$ te su izvijestili o većem pribavljanju STEM materijala za dijete $(\beta=-.12 ; p<.001)$. No, u oba slučaja, radi se o malim efektima. S druge strane, učenice su imale više postignuće iz matematike od učenika, no i tu se radi o vrlo malom učinku $(\beta=.07-08$; $p<.001)$. Nije bilo rodnih razlika ni u jednom od motivacijskih uvjerenja u matematici. Stariji učenici su imali nešto niži interes $(\beta=-.06 ; p=$ $.024)$ te nižu percepciju važnosti matematike $(\beta=-.14 ; p<.001)$ nego mlađi učenici. Stariji učenici su također izvijestili o rjeđem bavljenju matematičkim aktivnostima $(\beta=-.07--.15 ; p$ $<$.05) nego mlađi učenici. U modelu s učeničkom važnosti matematike prošlo postignuće iz matematike bilo je negativan prediktor roditeljskog poticanja $(\beta=-.19 ; p=.005)$ i roditeljskog pribavljanja STEM materijala $(\beta=-.13 ; p=.038)$. U modelu sa samoefikasnosti, prošlo je postignuće negativno predviđalo učeničko bavljenje matematičkim aktivnostima u slobodno vrijeme $(\beta=-.27 ; p<.001)$. U sva tri modela učeničko postignuće je pozitivno i snažno predviđalo postignuće iz matematike godinu dana kasnije $(\beta=.44-53 ; p<.001)$. Kada su u obzir uzeti svi ostali roditeljski utjecaji, obrazovanje roditelja nije izravno predviđalo učeničke ishode u matematici, izuzev postignuća za koje je pronađen vrlo mali pozitivni efekt obrazovanje roditelja $(\beta=.07 ; p<.001)$.

Kao što je vidljivo iz tablice u Prilogu 8, od svih učeničkih obrazovnih ishoda najveći postotak varijance objašnjen je u učeničkom postignuću iz matematike te je taj postotak ovisno o modelu iznosio između 75 i 78 \%. Modelom je objašnjen i visok postotak varijance učeničke samoefikasnosti u matematici (72\%), dok je postotak objašnjene varijance varijable učeničkog interesa i važnosti matematike bio niži (31 \%; 23 \%). Ovisno o modelu, objašnjeno je između 27 i $36 \%$ varijance učeničkog bavljenja matematičkim aktivnostima u slobodno vrijeme.

4. 2. 3. Procjena izravnih puteva u strukturalnim modelima roditeljskih odrednica učeničkih obrazovnih ishoda u tehničkoj kulturi

Nadalje su provjereni strukturalni modeli u području tehničke kulture. Kao i u slučaju matematičkih modela, i ovdje su svi putevi specificirani na osnovi istraživačkih hipoteza (hipoteze 1a, 2a, 2b, 2c, 3a). Veze između kontrolnih varijabli i svih ostalih endogenih varijabli su, kao i u modelima iz matematike, postavljene na temelju pregleda značajnosti bivarijatnih korelacija između pojedinih parova varijabli. U svakom je modelu specificirano šest kovarijanci između rezidualnih varijanci četiri roditeljska ponašanja. I u ovim su modelima nakon 
inspekcije inicijalnog strukturalnog modela, statistički neznačajni strukturalni putevi fiksirani na nulu, u svrhu postavljanja što jednostavnijih modela.

Početni strukturalni model s varijablom učeničke samoefikasnosti u tehničkoj kulturi imao je većinom prihvatljive indekse pristajanja: Yuan-Bentler $\chi^{2}(305)=1336.68, p<.001$; $\chi^{2} / d f=4.38 ; \mathrm{R}-\mathrm{CFI}=.91 ; \mathrm{R}-\mathrm{TLI}=.89 ; \mathrm{R}-\mathrm{RMSEA}=.058,90 \%$ CI $[.055, .062] ; \mathrm{SRMR}=$ .056. Nakon što je 16 neznačajnih puteva fiksirano na nulu model je i dalje imao prihvatljivo pristajanje podacima (Tablica 7) koje nije bilo statistički značajno lošije od pristajanja punog modela: $\Delta \mathrm{YB} \chi^{2}(16)=19.62, p=.238$.

Početni strukturalni model s varijablom učeničkog interesa za tehničku kulturu imao je također većinom prihvatljive indekse pristajanja: Yuan-Bentler $\chi^{2}(279)=1223.36, p<.001$; $\chi^{2} / d f=4.38 ; \mathrm{R}-\mathrm{CFI}=.91 ; \mathrm{R}-\mathrm{TLI}=.89 ; \mathrm{R}-\mathrm{RMSEA}=.058,90 \% \mathrm{CI}[.055, .062] ; \mathrm{SRMR}=.057$. Nakon što je u modelu 16 neznačajnih puteva fiksirano na nulu test hi-kvadrat razlike ukazao je na značajno pogoršanje modela: $\Delta \mathrm{YB} \chi^{2}(16)=28.41, p=.028$. Stoga su pregledani modifikacijski indeksi za sve puteve koji su fiksirani na nulu. Najveći modifikacijski indeks bio je povezan s oslobađanjem strukturalnog puta od roditeljskog modeliranja do učeničkog interesa za tehničku kulturu. Nakon što je ovaj parametar oslobođen, parsimonični model nije se razlikovao u pristajanju podacima od punog modela: $\Delta \mathrm{YB} \chi^{2}(15)=15.35, p=.427$. Međutim, u ovom je modelu put od roditeljskog pribavljanja materijala do učeničkog interesa postao neznačajan te je fiksiran na nulu, čime se pristajanje modela podacima nije pogoršalo: $\Delta \mathrm{YB} \chi^{2}(1)=3.71, p=.054$. Ovaj konačni model, u kojem su svi regresijski putevi bili značajni, imao je prihvatljive indekse pristajanja (Tablica 7).

Strukturalni model s varijablom učeničke važnosti tehničke kulture imao je većinom prihvatljive indekse pristajanja, izuzev nešto nižih CFI i TLI indeksa: Yuan-Bentler $\chi^{2}(277)=$ $1328.29, p<.001 ; \chi^{2} / d f=4.80 ; \mathrm{R}-\mathrm{CFI}=.89 ; \mathrm{R}-\mathrm{TLI}=.86 ; \mathrm{R}-\mathrm{RMSEA}=.062,90 \%$ CI [.058, $.065] ;$ SRMR $=.058$. Nakon fiksiranja 18 neznačajnih puteva na nulu, kao i u slučaju modela s interesom, jednostavniji model je imao značajno viši hi-kvadrat indeks u odnosu na puni model: $\Delta \mathrm{YB} \chi^{2}(18)=33.16, p=.016$. Ponovno su pregledani modifikacijski indeksi za puteve koji su fiksirani na nulu te se, kao i u slučaju modela s interesom, pokazalo da bi oslobađanje puta od roditeljskog modeliranja do učeničke važnosti tehničke kulture u najvećoj mjeri popravilo pristajanje modela. Nakon što je ovaj put oslobođen nije bilo statistički značajne razlike u pristajanju punog i parsimoničnog modela: $\Delta \mathrm{YB} \chi^{2}(17)=23.83, p=.124$. Konačni model je imao većinom prihvatljive indekse pristajanja (Tablica 7). 
Tablica 7. Indeksi pristajanja strukturalnih modela roditeljskih odrednica učeničkih obrazovnih ishoda u području tehničke kulture nakon što su neznačajni putevi fiksirani na nulu

\begin{tabular}{cccccccc}
\hline Model & YB $\chi^{2}$ & $d f$ & $\chi^{2} / d f$ & $\begin{array}{c}\text { R- } \\
\text { CFI }\end{array}$ & R-TLI & $\begin{array}{c}\text { R-RMSEA } \\
(90 \% \text { CI })\end{array}$ & SRMR \\
\hline Samoefikasnost & 1356.27 & 321 & 4.23 & .90 & .89 & $.057(.054-.060)$ & .058 \\
Interes & 1242.38 & 295 & 4.21 & .91 & .89 & $.057(.054-.060)$ & .058 \\
Važnost & 1351.74 & 294 & 4.60 & .89 & .87 & $.060(.057-.063)$ & .059 \\
\hline
\end{tabular}

U Prilogu 7 prikazane su standardizirane vrijednosti za sve izračunate direktne učinke $u$ sva tri strukturalna modela iz tehničke kulture. Slike 10, 11 i 12 prikazuju dobivene regresijske koeficijente za izravne puteve u modelima iz tehničke kulture koji su specificirani prvom, drugom i trećom skupinom istraživačkih hipoteza. Kao što je vidljivo iz Slike 10, u kontekstu prve skupine istraživačkih hipoteza, prema očekivanjima, u modelu $\mathrm{s}$ učeničkom samoefikasnosti, obrazovanje roditelja bilo je pozitivno povezano s roditeljskim poticanjem djetetovih interesa za tehničko područje $(\beta=.09 ; p=.010)$ te roditeljskim pribavljanjem materijala za dijete u STEM području $(\beta=.16 ; p<.001)$. S druge strane, suprotno hipotezi te suprotno nalazu dobivenom u modelu iz matematike, pokazalo se da su nakon kontrole prethodnog postignuća učenika obrazovaniji roditelji imali nešto negativnija uvjerenja specifična za dijete u tehničkoj kulturi $(\beta=-.15 ; p<.001)$.

Međutim, bivarijatna korelacija između obrazovanja roditelja i latentnog faktora roditeljskih uvjerenja bila je neznačajna $(r=-.05 ; p=.173)$, što upućuje na mogućnost da se radi o supresor efektu (Maassen i Bakker, 2001). Obrazovanje roditelja je moguća supresor varijabla za varijablu prošlog učeničkog postignuća u tehničkoj kulturi budući da su ove dvije varijable značajno pozitivno povezane $(r=.26 ; p<.001)$, a korelacija prošlog postignuća i latentnog faktora roditeljskih uvjerenja je također pozitivna i značajna $(r=.33 ; p<.001)$. Međutim, nakon uvođenja supresor varijable u regresijski model, regresijski koeficijent prediktora bi trebao porasti u odnosu na bivarijatnu korelaciju između prediktora i kriterija, no u našem slučaju je taj porast bio neznatan $(\beta=.36 ; p<.001 ; r=.33 ; p<.001)$.

Maassen i Bakker (2001) upozoravaju da klasične slučajeve supresije treba razlikovati od slučajeva tzv. maskirajućih varijabli. U algebarskom smislu ove dvije pojave su vrlo slične no njihove interpretacije se bitno razlikuju. Budući da obrazovanje roditelja u SEM modelu značajno negativno predviđa interes učenika za tehničku kulturu $(\beta=-.18 ; p<.001)$, kao i percepciju važnosti ovog predmeta $(\beta=-.15 ; p<.001)$, moguće je da je nezavisan doprinos obrazovanja roditelja u objašnjenju roditeljskih uvjerenja o djetetu u ovom predmetu uistinu 
negativan, a da prošlo učeničko postignuće učenika „maskira“ tu negativnu povezanost. U kontekstu tog objašnjenja, dio varijance u obrazovanju roditelja koji je pozitivno povezan $\mathrm{s}$ postignućem učenika pozitivno predviđa i uvjerenja roditelja u ovom predmetu. S druge strane, dio varijance u obrazovanju roditelja koji je nezavisan od postignuća učenika negativno predviđa roditeljska uvjerenja. Ova dva utjecaja se međusobno anuliraju što dovodi do nulte korelacije između obrazovanja roditelja i roditeljskih uvjerenja na bivarijatnoj razini ${ }^{28}$. U SEM modelu pak dobivamo uvid $\mathrm{u}$ nezavisan doprinos obrazovanja roditelja $\mathrm{u}$ predviđanju roditeljskih uvjerenja, nakon što smo već u obzir uzeli doprinos učeničkog postignuća. Ovi rezultati sugeriraju da kada su učenici izjednačeni po svom postignuću u tehničkoj kulturi, obrazovaniji roditelji imaju nešto negativnija uvjerenja specifična za dijete u ovom predmetu.

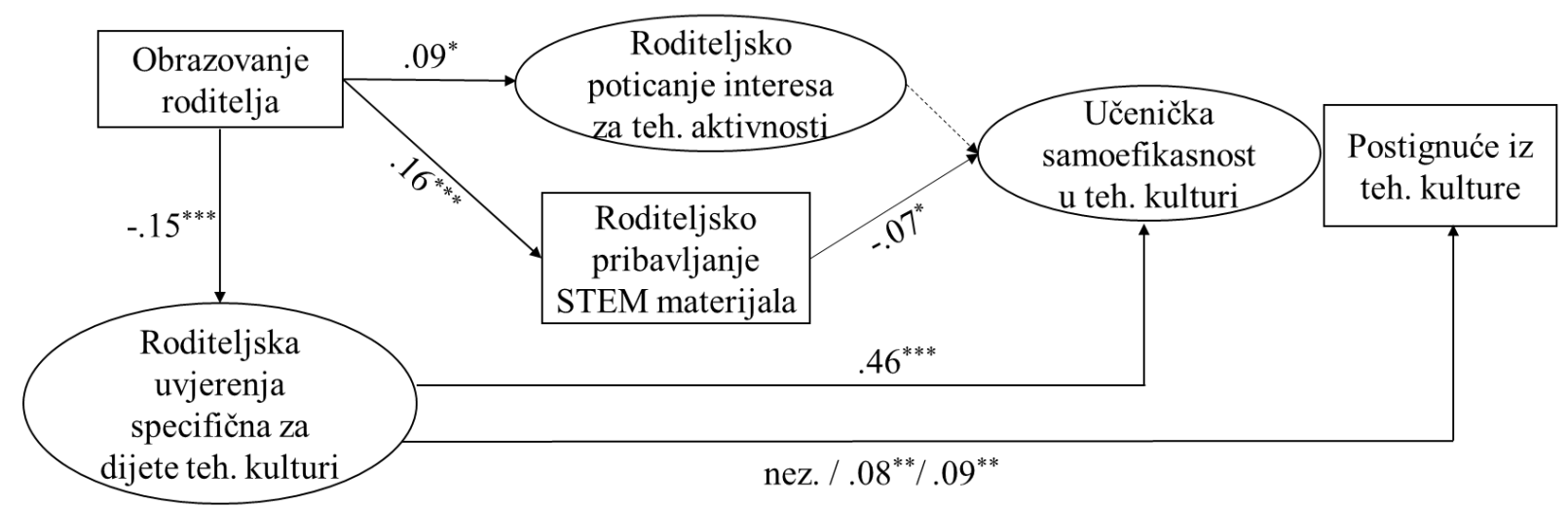

Slika 10. Izravni standardizirani regresijski učinci koji su dio istraživačkih hipoteza prve skupine. Prva vrijednost koeficijenta se odnosi na model s učeničkom samoefikasnosti, druga na model s učeničkim interesom, a treća vrijednost na model s učeničkom važnosti tehničke kulture. nez. $=$ put je u početnom modelu bio statistički neznačajan te je stoga u konačnom modelu fiksiran na nulu. Isprekidanom linijom je prikazan put koji je bio neznačajan u sva tri modela (modelu sa samoefikasnosti, interesom i važnosti).

$* p<.05 ; * * p<.01 ; * * * p<.001$.

Kao što je vidljivo iz Slike 11, prema očekivanjima, više prošlo učeničko postignuće iz tehničke kulture bilo je prediktor pozitivnijih roditeljskih uvjerenja specifičnih za dijete u tehničkoj kulturi, iako je efekt bio slabiji nego u području matematike: $\beta=.37-.42 ; p<.001$. Nadalje, u skladu s hipotezama druge skupine te kao i u slučaju nalaza u matematici, roditeljska uvjerenja pozitivno su predviđala učeničku samoefikasnost $(\beta=.46 ; p<.001)$, interes $(\beta=.38$; $p<.001)$ i važnost tehničke kulture $(\beta=.29 ; p<.001)$. Kao i u slučaju matematičkih modela, $\mathrm{i}$ $\mathrm{u}$ tehničkom je području učeničko prethodno postignuće iz predmeta pozitivno predviđalo kasniju učeničku samoefikasnost u predmetu $(\beta=.31 ; p<.001)$, ali ne i učenički interes $\mathrm{i}$

\footnotetext{
${ }^{28}$ Za više detalja o tzv. maskirajućim varijablama vidi Maassen i Bakker (2001).
} 
važnost tehničke kulture. Također u skladu s nalazima dobivenim za matematiku, i u tehničkom je području od svih učeničkih motivacijskih uvjerenja, jedino učenička samoefikasnost predviđala kasnije školsko postignuće u tehničkoj kulturi $(\beta=.16 ; p<.001)$. Roditeljska uvjerenja su pozitivno predviđala kasnije učeničko postignuće iz tehničke kulture u modelu s učeničkim interesom $(\beta=.08 ; p=.002)$ i u modelu s učeničkom važnosti $(\beta=.09 ; p=.001)$. No, ti su učinci bili vrlo mali te značajno niži nego isti učinci u modelima iz matematike.

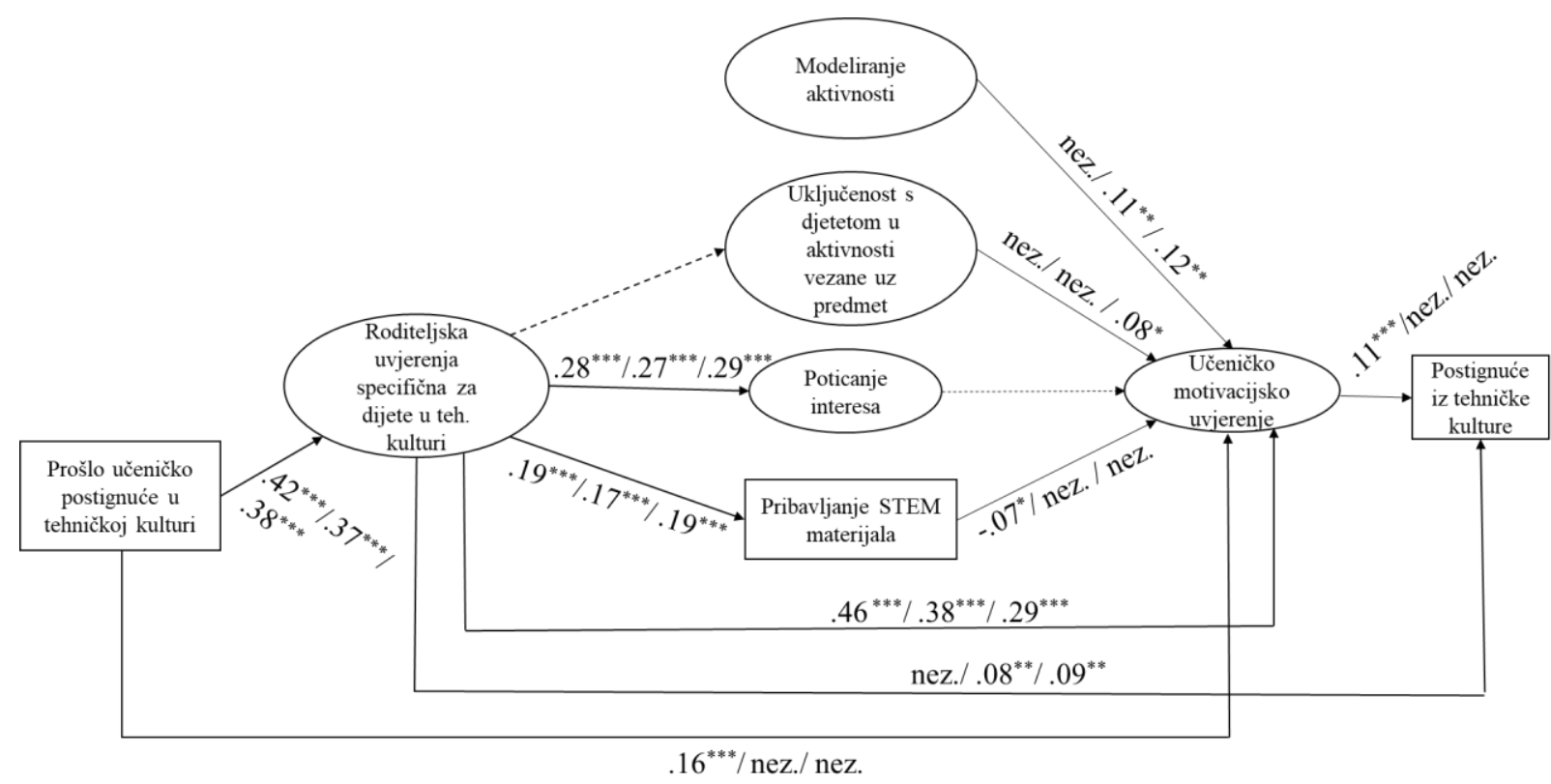

Slika 11. Izravni standardizirani regresijski učinci koji su dio istraživačkih hipoteza druge skupine. Prva vrijednost koeficijenta se odnosi na model s učeničkom samoefikasnosti, druga na model s učeničkim interesom, a treća vrijednost na model s učeničkom važnosti tehničke kulture. nez. $=$ put je u početnom modelu bio statistički neznačajan te je stoga u konačnom modelu fiksiran na nulu. Isprekidanom linijom su prikazani putevi koji su bili neznačajni u sva tri modela (modelu sa samoefikasnosti, interesom i važnosti).

$* p<.05 ; * * p<.01 ; * * * p<.001$.

Roditeljska uvjerenja su, u skladu s hipotezom te u skladu s nalazima za matematiku, bila pozitivno povezana s poticanjem djetetovih interesa za tehničko područje $(\beta=.27-.29 ; p$ $<.001)$ te s pribavljanjem STEM materijala za dijete $(\beta=.17-.19 ; p<.001)$. Međutim, za razliku od nalaza za matematiku, pozitivnija roditeljska uvjerenja nisu bila povezana s nižom uključenosti u djetetove obaveze iz tehničke kulture.

U odnosu na modele iz matematike, roditeljska ponašanja su u više slučajeva predviđala učenička motivacijska uvjerenja u tehničkoj kulturi. Međutim, ti su efekti većinom bili mali. Roditeljsko modeliranje tehničkih aktivnosti je pozitivno predviđalo učenički interes za tehničku kulturu $(\beta=.11 ; p<.01)$ i važnost tehničke kulture $(\beta=.12 ; p=.003)$. Roditeljska uključenost je pozitivno predviđala učeničku važnost tehničke kulture $(\beta=.08 ; p=.019)$. 
Također je pronađena vrlo niska negativna povezanost između roditeljskog pribavljanja STEM materijala za dijete i učeničke samoefikasnosti u tehničkoj kulturi $(\beta=-.07 ; p=.013)$.

Slika 12 prikazuje izravne puteve koji su specificirani hipotezama treće skupine. Kao i u slučaju modela iz matematike, frekvenciju učeničkog bavljenja slobodnim aktivnostima u tehničkom području pozitivno je predviđalo roditeljsko poticanje djetetovih interesa za tehničko područje $(\beta=.50-.56 ; p<.001)$. Roditeljsko modeliranje tehničkih aktivnosti je također predviđalo učeničko bavljenje tehničkim aktivnostima, ali je taj učinak bio negativan $(\beta=-.21--.28 ; p<.001)$. Ovdje treba napomenuti da je bivarijatna korelacija između latentnih varijabli roditeljskog modeliranja i učeničkog bavljenja aktivnostima u tehničkom području bila pozitivnog predznaka $(r=.14 ; p=.002)$. Ovakav nalaz ukazuje na supresor efekt pa su stoga dodatno uspoređene bivarijatne korelacije između prediktora učeničkih aktivnosti koji su uključeni u konačne SEM modele te regresijski koeficijenti za te prediktore.

Ova analiza ukazala je da je varijabla roditeljskog modeliranja negativni supresor za varijablu roditeljske uključenosti. Naime, negativna supresija događa se kada su (Maassen i Bakker, 2001): (a) prediktor i supresor u pozitivnoj korelaciji; (b) obje varijable su pozitivno povezane sa zavisnom varijablom; (c) u regresijskom modelu regresijski koeficijent jedne od varijabli dobije negativni predznak; (d) regresijski koeficijent prediktora poraste nakon uvođenja supresor varijable u model. Kao što je vidljivo iz korelacijske matrice u Prilogu 5 te konačnih regresijskih koeficijenata na Slici 12, ovi uvjeti prisutni su za varijable roditeljskog modeliranja i poticanja. Najprije, roditeljsko modeliranje je, kao supresor varijabla, nisko pozitivno povezano s učeničkim bavljenjem aktivnostima u tehničkom području $(r=.14 ; p=$ .002), dok je korelacija između roditeljskog poticanja i učeničkih aktivnosti znatno viša ( $r=$ $.43 ; p<.001)$. Kada su ove dvije varijable zajedno uvedene u model, koeficijent roditeljskog modeliranja je porastao, ali je promijenio predznak $(\beta=-.21--.28 ; p<.001)$. Koeficijent roditeljskog poticanja je ostao pozitivnog predznaka, ali je također porastao $(\beta=.50-.56 ; p<$ .001). Dodatna analiza je također pokazala da kada se roditeljsko poticanje isključi kao prediktor učeničkih aktivnosti iz SEM modela, a svi ostali prediktori učeničkih aktivnosti ostanu u modelu, roditeljsko modeliranje postaje pozitivan prediktor učeničkog bavljenja tehničkim aktivnostima $(\beta=.12-.16 ; p<.05)$. Ovaj nalaz dodatno potvrđuje da je modeliranje supresor varijabla za roditeljsko poticanje.

Nadalje, u skladu s hipotezom, sva tri motivacijska uvjerenja učenika u tehničkoj kulturi - samoefikasnost $(\beta=.21 ; p<.001)$, interes $(\beta=.36 ; p<.001)$ i važnost tehničke kulture $(\beta=$ $.29 ; p<.001)$ pozitivno su predviđala frekvenciju učeničkog bavljenja tehničkim aktivnostima u slobodne vrijeme. Frekvencija bavljenja tehničkim aktivnostima u slobodno vrijeme nije 
predviđala kasnije postignuće iz tehničke kulture, što je nalaz sličan onom za matematiku gdje je ovaj efekt bio značajan, ali vrlo mali.

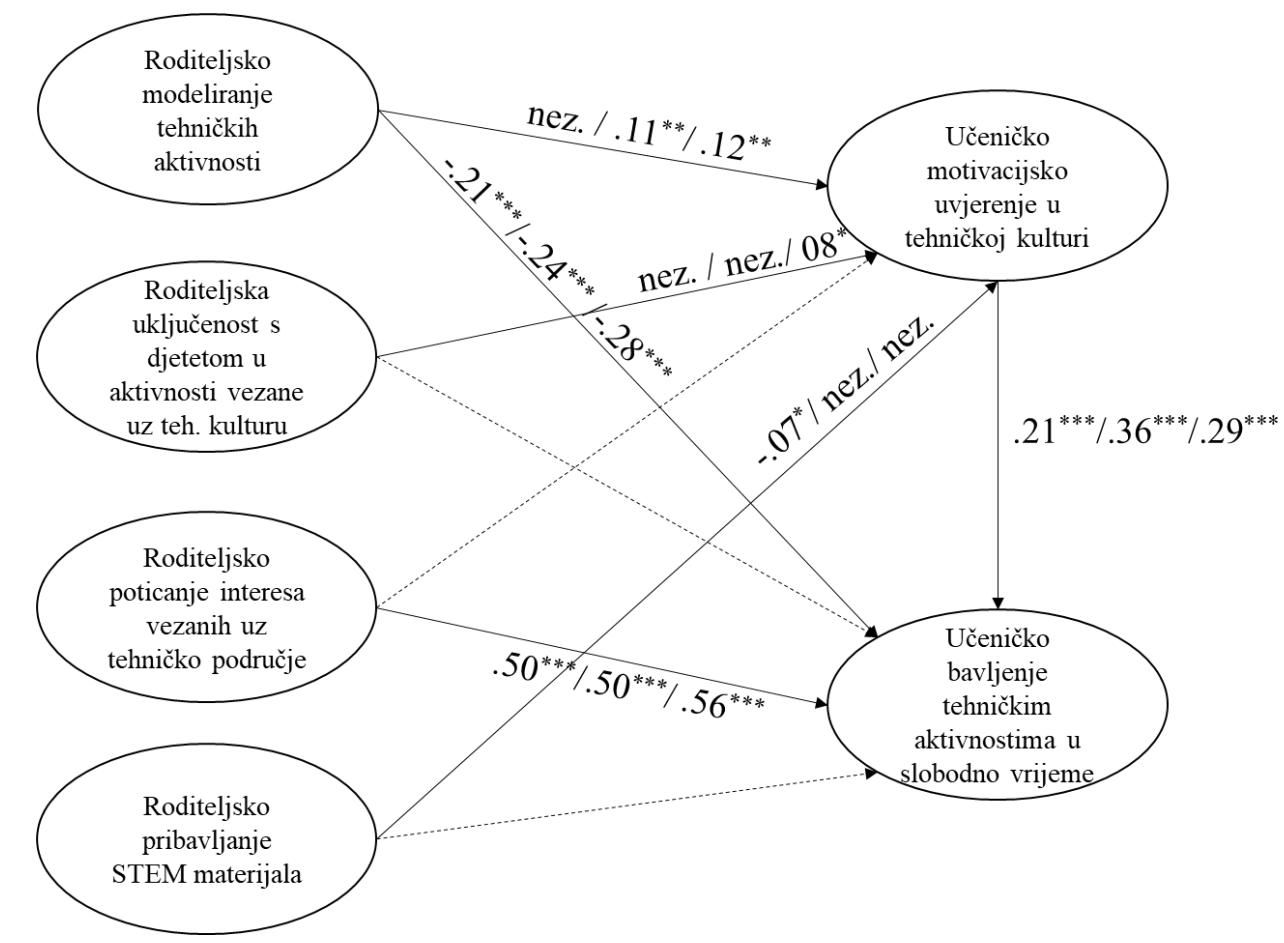

Slika 12. Izravni standardizirani regresijski učinci koji su dio istraživačkih hipoteza treće skupine. Prva vrijednost koeficijenta se odnosi na model s učeničkom samoefikasnosti, druga na model s učeničkim interesom, a treća vrijednost na model s učeničkom važnosti tehničke kulture. nez. $=$ put je u početnom modelu bio statistički neznačajan te je stoga u konačnom modelu fiksiran na nulu. Isprekidanom linijom su prikazani putevi koji su bili neznačajni u sva tri modela (modelu sa samoefikasnosti, interesom i važnosti).

$* p<.05 ; * * p<.01 ; * * * p<.001$.

U pogledu učeničkih kontrolnih varijabli, kao i u slučaju matematike, roditelji dječaka su imali nešto pozitivnija uvjerenja specifična za dijete u tehničkoj kulturi $(\beta=-.11--.12 ; p<$ .001). Pored nešto većeg roditeljskog pribavljanja STEM materijala u slučaju dječaka nego u slučaju djevojčica, što je već utvrđeno u sklopu procjene matematičkih modela ${ }^{29}$, također je utvrđeno da roditelji muške djece značajno češće potiču djetetove interese za tehničke aktivnosti nego roditelji ženske djece $(\beta=-.19 ; p<.001)$. Za razliku od motivacijskih uvjerenja u matematici za koja nisu pronađene rodne razlike, učenici su izvijestili o višem interesu $(\beta=$ $.17 ; p<.001)$ te većoj važnosti tehničke kulture nego učenice $(\beta=-.22 ; p<.001)$. Uz kontrolu ostalih varijabli u modelima, dobna kohorta učenika pokazala se neznačajnim prediktorom ostalih konstrukata u modelima, izuzev malog učinka koji je dobiven u modelu s učeničkom

\footnotetext{
${ }^{29}$ Roditeljsko pribavljanje STEM materijala je konstrukt koji ima iste indikatore i u modelima iz matematike i tehničke kulture.
} 
samoefikasnosti u kojem su stariji učenici izvijestili o nešto rjeđem bavljenju tehničkim aktivnostima u slobodno vrijeme $(\beta=-.10 ; p=.005)$. Prošlo učeničko postignuće iz tehničke kulture bilo je negativan prediktor roditeljske uključenosti u djetetove obaveze iz ovog predmeta $(\beta=-.21--.22 ; p<.001)$. U sva tri modela je učeničko postignuće pozitivno i snažno predviđalo postignuće iz tehničke kulture godinu dana kasnije $(\beta=.62-.63 ; p<.001)$. Naposljetku, za razliku od modela iz matematike u kojima obrazovanje roditelja većinom nije zadržalo značajan prediktivni učinak, u modelima iz tehničke kulture se pokazalo da djeca obrazovanijih roditelja izvještavaju o nižem interesu za tehničku kulturu $(\beta=-.18 ; p<.001) \mathrm{i}$ manjoj važnosti ovog predmeta $(\beta=-.15 ; p<.001)$. S druge strane, u sva tri modela su djeca obrazovanijih roditelja imala više postignuće iz ovog predmeta $(\beta=.13-.14 ; p<.001)$.

U tablici u Prilogu 8 je vidljivo da je, kao i u slučaju matematike, i u modelima iz tehničke kulture od svih učeničkih obrazovnih ishoda najveći postotak varijance objašnjen u učeničkom postignuću iz predmeta $(51-52 \%)$. Obrazac postotka objašnjene varijance u učeničkim motivacijskim uvjerenjima isti je kao i obrazac utvrđen u modelima iz matematike - najviše varijance objašnjeno je u učeničkoj samoefikasnost u tehničkoj kulturi (28 \%), zatim $\mathrm{u}$ interesu za predmet (20\%), a najmanje u važnosti predmeta (18\%). Ovisno o modelu, objašnjeno je između 27 i 34 \% varijance učeničkog bavljenja tehničkim aktivnostima u slobodno vrijeme.

4. 2. 4. Usporedba relativnog doprinosa roditeljskih varijabli u objašnjavanju učeničkih obrazovnih ishoda u matematici i tehničkoj kulturi

Naposljetku su uspoređeni relativni doprinosi pojedinih vrsta roditeljskih varijabli u objašnjavanju učeničkih obrazovnih ishoda. Budući da su prediktivni efekti obrazovanja roditelja u cjelokupnom modelu bili slabi ili neznačajni, usporedit ćemo ulogu roditeljskih uvjerenja i ponašanja. Najprije treba napomenuti da u konceptualnom modelu roditeljska uvjerenja i ponašanja nisu postavljena kao direktni prediktori istih učeničkih varijabli. Izuzetak su učenička motivacijska uvjerenja za koja smo pretpostavili da ih direktno predviđaju i uvjerenja i ponašanja roditelja. Međutim, roditeljska uvjerenja nismo postavili kao prediktore učeničkog bavljenja aktivnostima u matematičkom i tehničkom području, a roditeljska ponašanja nismo postavili kao prediktore učeničkog postignuća. Stoga smo dodatnim analizama provjerili jesu li ove pretpostavke opravdane. $U$ tu smo svrhu testirali strukturalne modele $u$ kojima su dodani opisani putevi. Ni u jednom od modela iz matematike niti iz tehničke kulture put od roditeljskih uvjerenja do učeničkog bavljenja izvanškolskim aktivnostima nije bio 
značajan, kao što niti jedan od puteva od roditeljskih ponašanja do učeničkog postignuća nije bio značajan ${ }^{30}$. Stoga smo te puteve uistinu mogli smatrati nultima, što nam olakšava usporedbu prediktivne uloge roditeljskih uvjerenja i ponašanja.

Prema postavljenoj hipotezi, bilo je očekivano da će roditeljska uvjerenja imati snažniji i konzistentniji učinak u predviđanju učeničkih obrazovnih ishoda od roditeljskih ponašanja. Generalno gledano, ova je hipoteza potvrđena. Naime, i u matematici i u tehničkoj kulturi roditeljska uvjerenja su bila značajno snažniji i konzistentniji prediktori učeničke motivacije za predmet nego roditeljska ponašanja. $\mathrm{U}$ oba su predmeta roditeljska uvjerenja predviđala sva tri motivacijska uvjerenja učenika i ti su efekti bili u većini slučajeva umjereni do snažni. S druge strane, roditeljska ponašanja su se u oba predmeta predviđala samo učenički interes ili važnost predmeta i ti su efekti u svim slučajevima bili mali. Nadalje, roditeljska uvjerenja su također bila značajan prediktor učeničkog postignuća u matematici. U tehničkoj kulturi je ta poveznica bila niska, no to se vjerojatno može pripisati vrlo maloj varijanci ocjena iz tehničke kulture. Roditeljska ponašanja pak nisu bila prediktor postignuća ni u jednom predmetu. Naposljetku, roditeljska ponašanja su bila značajan prediktor jedino učeničkih slobodnih aktivnosti u matematičkom i tehničkom području, dok roditeljska uvjerenja tu nisu imala prediktivni učinak. Međutim, treba napomenuti da su samo neka roditeljska ponašanja bila značajni prediktori učeničkih aktivnosti te se u većini slučajeva radilo o malim efektima.

Također je bilo očekivano da će ona roditeljska ponašanja koja podrazumijevaju veći stupanj interakcije roditelj-dijete (roditeljska uključenost i poticanje) biti snažniji prediktori učeničkih ishoda nego ona ponašanja koja podrazumijevaju manji stupanj ove interakcije (roditeljsko modeliranje i pribavljanje materijala). Uvidom u konačne strukturalne modele pokazalo se da je ova hipoteza u cijelosti potvrđena u modelima iz matematike. Naime, roditeljsko modeliranje i pribavljanje materijala nisu predviđali nijedan učenički obrazovni ishod vezan uz matematiku, dok su roditeljsko poticanje i uključenost predviđali pojedina učenička motivacijska uvjerenja te bavljenje matematičkim aktivnostima. Međutim, u tehničkoj kulturi su roditeljska uključenost i roditeljsko pribavljanje materijala imali podjednako slab doprinos u objašnjavanju učeničkih obrazovnih ishoda, dok su roditeljsko modeliranje i poticanje interesa imali snažniji doprinos u objašnjavanju učeničkih obrazovnih ishoda.

\footnotetext{
${ }^{30}$ Ove analize nisu prikazane u radu, ali su dostupne na upit.
} 
4. 2. 5. Procjena neizravnih puteva u strukturalnim modelima roditeljskih odrednica učeničkih obrazovnih ishoda u matematici i tehničkoj kulturi

Nakon procjene izravnih puteva u svim SEM modelima, proveli smo procjenu neizravnih puteva koji su dio medijacijskih hipoteza. Kao što je opisano u potpoglavlju 3. 4. 3., kako bismo mogli izračunati i formalno testirati neizravni učinak, nužno je da put od prediktorske varijable do medijatorske varijable bude statistički značajan, kao i put od medijatorske varijable do kriterijske varijable. U Tablici 8 su prikazani izravni, neizravni i ukupni učinci za medijacijske hipoteze koje su, prema ovim kriterijima, mogle biti formalno testirane.

\section{Medijacijske hipoteze prve skupine}

Medijacijske hipoteze prve skupine odnose se na neizravnu povezanost obrazovanja roditelja s učeničkim obrazovnim ishodima. U modelima iz matematike ove hipoteze nisu potvrđene budući da određeni izravni efekti koji su uključeni u ove hipoteze nisu bili značajni. Naime, prvi dio hipoteza je predviđao da će obrazovanje roditelja biti povezano s višim učeničkim postignućem iz predmeta preko pozitivnijih roditeljskih uvjerenja specifičnih za dijete. Ova hipoteza u matematici nije potvrđena budući da obrazovanje roditelja nije bilo povezano s roditeljskim uvjerenjima u matematici (Slika 7). Drugi dio medijacijskih hipoteza prve skupine predviđao je da će odnos između obrazovanja roditelja i učeničke samoefikasnosti u predmetu biti posredovan preko pozitivnijih roditeljskih uvjerenja i češćih roditeljskih ponašanja (poticanja interesa i pribavljanje STEM materijala). U modelima iz matematike ova hipoteza nije potvrđena budući da je obrazovanje roditelja predviđalo jedino višu razinu roditeljskog pribavljanja STEM materijala $(\beta=.13 ; p<.001)$, no ovo ponašanje nije predviđalo učeničku samoefikasnosti u matematici (Slika 7).

U modelima iz tehničke kulture bilo je moguće testirati većinu medijacijskih hipoteza prve skupine, iako su neki izravni učinci uključeni u ove hipoteze bili vrlo mali (Slika 10). Medijacijski učinak roditeljskih uvjerenja u objašnjenju neizravne povezanosti obrazovanja roditelja i učeničkog postignuća bilo je moguće testirati u modelima s učeničkim interesom i važnosti s obzirom da u modelu sa samoefikasnosti put od roditeljskih uvjerenja do učeničkog postignuća nije bio značajan. I u modelu s interesom i važnosti ovaj se neizravni učinak pokazao značajnim, ali vrlo malim $(\beta=-.01 ; p=.015)$. Iako smo očekivali da će više obrazovanje roditelja biti povezano s pozitivnijim roditeljskim uvjerenjima koja će pak doprinijeti višem 
učeničkom postignuću iz predmeta, dobivena medijacijska veza je dijelom drugačijeg smjera. Naime, obrazovaniji roditelji imaju nešto slabija uvjerenja o sposobnostima i interesima svoje djece za tehničku kulturu, a ova uvjerenja pak pozitivno predviđaju kasnije postignuće učenika u predmetu. Treba napomenuti da je izravna veza između roditeljskih uvjerenja i učeničkog postignuća pritom vrlo niska (model s interesom: $\beta=.08 ; p=.002$; model s važnosti: $\beta=.09$; $p=.001)$, što se vjerojatno može pripisati vrlo malom varijabilitetu učeničkih ocjena iz tehničke kulture. U oba je modela obrazovanje roditelja osim neizravnog, imalo i izravan učinak na učeničko postignuće $(\beta=.12 ; p<.001)$.

Nadalje su testirani neizravni efekti roditeljskih uvjerenja i pribavljanja STEM materijala u objašnjavanju poveznice između obrazovanja roditelja i učeničke samoefikasnosti u tehničkoj kulturi. Medijacijska uloga roditeljskog poticanja nije mogla biti testirana budući da obrazovanje roditelja nije bilo povezano s ovim ponašanjem. Neizravan učinak obrazovanja roditelja na učeničku samoefikasnosti u tehničkoj kulturi preko roditeljskih uvjerenja bio je statistički značajan $(\beta=-.07 ; p<.001)$. Neizravan učinak preko pribavljanja STEM materijala također je bio značajan, ali vrlo mali $(\beta=-.01 ; p=.022)$. Smjerovi izravnih učinaka koji su uključeni u ove medijacijske odnose nisu sasvim u skladu s postavljenim hipotezama. Naime, kao što je već rečeno u prethodnom odlomku, suprotno očekivanjima, obrazovaniji roditelji imaju uvjerenja o nižim sposobnostima i interesima svoje djece za tehničku kulturu, no, u skladu s očekivanjima, ova uvjerenja umjereno do snažno predviđaju kasniju samoefikasnost učenika u tehničkoj kulturi $(\beta=.46 ; p<.001)$. Također, prema očekivanjima, obrazovaniji roditelji nešto češće nabavljaju STEM materijale za svoje dijete, no frekvencija ovog ponašanja negativno je predviđala učeničku samoefikasnost $u$ tehničkoj kulturi. Međutim, treba napomenuti da je taj izravni efekt bio vrlo nizak $(\beta=-.07 ; p=.013)$.

\section{Medijacijske hipoteze druge skupine}

U okviru medijacijskih hipoteza druge skupine predviđeno je da će učeničko prošlo postignuće u predmetu biti pozitivno povezano s kasnijom samoefikasnosti u predmetu izravno, ali i neizravno - preko pozitivnijih roditeljskih uvjerenja. Ova medijacijska hipoteza je potvrđena u oba predmeta budući da je neizravni učinak bio značajan i u modelu iz matematike $(\beta=.56 ; p<.001)$ i u modelu iz tehničke kulture $(\beta=.19 ; p<.001)$. U matematici se radi o velikom neizravnom efektu, a u tehničkoj kulturi o efektu umjerene veličine (Cohen, 1988).

Nadalje, u sklopu medijacijskih hipoteza druge skupine također je previđeno da će roditeljska uvjerenja biti povezana s učeničkim motivacijskim uvjerenjima u predmetu dijelom 
neizravno - preko tri vrste roditeljskih ponašanja. Nakon uvida u dobivene izravne učinke (Slika 8), ovaj je medijacijski efekt u matematici bilo moguće provjeriti samo u modelu s učeničkim interesom budući da nijedno od roditeljskih ponašanja nije predviđalo učeničku samoefikasnost i važnost matematike. Testiran je neizravni efekt 'roditeljska uvjerenja $\rightarrow$ roditeljska uključenost u djetetove obaveze iz matematike $\rightarrow$ učenički interes za matematiku' te neizravni efekt 'roditeljska uvjerenja $\rightarrow$ roditeljsko poticanje djetetovih interesa u matematici $\rightarrow$ učenički interes za matematiku'. Pokazalo se da su oba testirana neizravna učinka bila mala (Cohen, 1988), ali statistički značajna - neizravni učinak preko roditeljske uključenosti iznosio je $\beta=.05 ; p=.006$, dok je neizravni učinak preko roditeljskog poticanja interesa iznosio $\beta=$ $.03 ; p=.002$. Negativnija roditeljska uvjerenja u matematici predviđala su češću roditeljsku uključenost $u$ djetetove obaveze iz ovog predmeta, što je pak bilo povezano s nižim kasnijim interesom djeteta za matematiku. S druge strane, pozitivnija roditeljska uvjerenja predviđala su češće roditeljsko poticanje djetetovih interesa za matematiku što je u konačnici predviđalo viši kasniji interes djeteta za matematiku.

Uvidom u izravne efekte u modelima iz tehničke kulture (Slika 11), vidljivo je da je bilo moguće testirati jedino neizravan učinak 'roditeljsko uvjerenje $\rightarrow$ roditeljsko pribavljanje STEM materijala $\rightarrow$ učenička samoefikasnosti'. Ovaj je efekt bio značajan, ali vrlo mali $(\beta=-$ $.01 ; p=.028)$ budući da je, kao što je već spomenuto, korelacija između roditeljskog pribavljanja materijala i učeničke samoefikasnosti niska $(\beta=-.07 ; p=.002)$. Pozitivnija roditeljska uvjerenja predviđala su veće pribavljanje STEM materijala za dijete što je pak predviđalo nižu učeničku samoefikasnost u tehničkoj kulturi.

U sklopu druge skupine hipoteza, također je bilo predviđeno da će roditeljska uvjerenja biti dijelom neizravno povezana s kasnijim učeničkim postignućem preko učeničkih motivacijskih uvjerenja. I u slučaju matematike i tehničke kulture ovaj je medijacijski učinak testiran u modelu s učeničkom samoefikasnosti budući da je od tri motivacijska uvjerenja samo samoefikasnost izravno predviđala kasnije postignuće. U oba modela je testirani učinak bio značajan - pozitivnija roditeljska uvjerenja predviđala su kasniju višu učeničku samoefikasnost u predmetu koja je predviđala više kasnije postignuće iz predmeta. U matematici je ovaj neizravni efekt bio velik $(\beta=.20 ; p<.001)$, a u tehničkoj kulturi mali $(\beta=.05 ; p<.001)$. Uz to je u tehničkoj kulturi učinak roditeljskih uvjerenja na kasnije učeničko postignuće bio isključivo neizravan, dok su roditeljska uvjerenja u matematici imala i izravan učinak na učeničko postignuće $(\beta=.20 ; p<.001)$, 
U sklopu hipoteza treće skupine bilo je očekivano da će roditeljska ponašanja predviđati učeničko bavljenje aktivnostima u matematičkom/tehničkom području dijelom neizravno preko učeničkih motivacijskih uvjerenja u ovim predmetima. U matematici je ova hipoteza testirana za model s učeničkim interesom budući da su od tri motivacijska uvjerenja roditeljska ponašanja predviđala jedino kasniji interes za matematiku (Slika 9). Ovaj neizravni učinak je bio značajan $(\beta=-.06 ; p=.006)$, pri čemu je rjeđa roditeljska uključenost predviđala viši učenički interes za matematiku koji je predviđao češće bavljenje matematičkim aktivnostima u slobodno vrijeme. Neizravan učinak roditeljskog poticanja je također bio značajan $(\beta=.09 ; p$ <.001) - češće roditeljsko poticanje interesa predviđalo je viši učenički interes za matematiku koji je bio povezan s češćim bavljenjem matematičkim aktivnostima u slobodno vrijeme.

U modelima iz tehničke kulture također su dobiveni značajni, ali mali neizravni učinci. Roditeljsko modeliranje tehničkih aktivnosti je bilo neizravno povezano s učeničkim bavljenjem tehničkim aktivnostima preko višeg učeničkog interesa za tehničku kulturu $(\beta=.04$; $p=.004)$ i veće učeničke važnosti tehničke kulture $(\beta=.03 ; p=.005)$. Također je dobiven vrlo mali neizravni učinak roditeljske uključenosti $(\beta=.02 ; p=.029)$. Češća uključenost bila je povezana s većom važnosti tehničke kulture koja je predviđala češće bavljenje aktivnostima u ovom području. Naposljetku, dobiven je vrlo mali neizravni učinak roditeljskog pribavljanja STEM materijala na učeničko bavljenje tehničkim aktivnostima preko učeničke samoefikasnosti $(\beta=-.02 ; p=.024)$. Veće pribavljanje STEM materijala za dijete je predviđalo nižu učeničku samoefikasnost u tehničkoj kulturi koja je pak predviđala češće bavljenje tehničkim aktivnostima u slobodno vrijeme. 
Tablica 8. Pregled dobivenih standardiziranih izravnih, neizravnih i ukupnih učinaka pri testiranju medijacijskih hipoteza u istraživanju

Matematika

Tehnička kultura

\begin{tabular}{|c|c|c|c|c|c|c|c|}
\hline $\begin{array}{l}\text { Skupina } \\
\text { hipoteza }\end{array}$ & Strukturalni put (prediktor - medijator - kriterij) & $\begin{array}{l}\text { Izravan } \\
\text { učinak }\end{array}$ & $\begin{array}{l}\text { Neizravan } \\
\text { učinak }\end{array}$ & $\begin{array}{l}\text { Ukupni } \\
\text { učinak }\end{array}$ & $\begin{array}{l}\text { Izravan } \\
\text { učinak }\end{array}$ & $\begin{array}{l}\text { Neizravan } \\
\text { učinak }\end{array}$ & $\begin{array}{l}\text { Ukupni } \\
\text { učinak }\end{array}$ \\
\hline \multirow{3}{*}{$\begin{array}{c}\text { Prva } \\
\text { skupina }\end{array}$} & Obrazovanje roditelja $\rightarrow$ Roditeljska uvjerenja $\rightarrow$ Postignuće učenika & - & - & - & $.13^{* * *}$ & $-.01^{*}$ & $.12^{* * *}$ \\
\hline & Obrazovanje roditelja $\rightarrow$ Roditeljska uvjerenja $\rightarrow$ Samoefikasnost učenika & - & - & - & - & $-.07^{* * *}$ & $-.08^{* * *}$ \\
\hline & Obrazovanje roditelja $\rightarrow$ Roditeljsko pribavljanje $\rightarrow$ Samoefikasnost učenika & - & - & - & - & $-.01^{*}$ & $-.08^{* * *}$ \\
\hline \multirow{5}{*}{$\begin{array}{l}\text { Druga } \\
\text { skupina }\end{array}$} & Prošlo postignuće učenika $\rightarrow$ Roditeljska uvjerenja $\rightarrow$ Samoefikasnost učenika & $.21^{* * *}$ & $.56^{* * * *}$ & $.77^{* * * *}$ & $.16^{* * *}$ & $.19^{* * *}$ & $.35^{* * *}$ \\
\hline & Roditeljska uvjerenja $\rightarrow$ Roditeljska uključenost $\rightarrow$ Interes učenika & $.45^{* * *}$ & $.05^{* *}$ & $.53^{* * *}$ & - & - & - \\
\hline & Roditeljska uvjerenja $\rightarrow$ Roditeljsko poticanje $\rightarrow$ Interes učenika & $.45^{* * *}$ & $.03^{* *}$ & $.53^{* * *}$ & - & - & - \\
\hline & Roditeljska uvjerenja $\rightarrow$ Roditeljsko pribavljanje $\rightarrow$ Samoefikasnost učenika & - & - & - & $.46^{* * *}$ & $-.01^{*}$ & $.45^{* * *}$ \\
\hline & Roditeljska uvjerenja $\rightarrow$ Samoefikasnost učenika $\rightarrow$ Postignuće učenika & $.20^{* * * *}$ & $.20^{* * *}$ & $.40^{* * *}$ & .00 & $.05^{* * *}$ & $.05^{* * *}$ \\
\hline \multirow{6}{*}{$\begin{array}{l}\text { Treća } \\
\text { skupina }\end{array}$} & Roditeljska uključenost $\rightarrow$ Interes učenika $\rightarrow$ Slobodne aktivnosti učenika & .00 & $-.06^{* *}$ & $-.06^{* *}$ & - & - & - \\
\hline & Roditeljsko poticanje $\rightarrow$ Interes učenika $\rightarrow$ Slobodne aktivnosti učenika & $.11^{* *}$ & $.09^{* * *}$ & $.20^{* * *}$ & - & - & - \\
\hline & Roditeljsko modeliranje $\rightarrow$ Interes učenika $\rightarrow$ Slobodne aktivnosti učenika & - & - & - & $-.24^{* * *}$ & $.04^{* *}$ & $-.20^{* *}$ \\
\hline & Roditeljsko modeliranje $\rightarrow$ Važnost predmeta $\rightarrow$ Slobodne aktivnosti učenika & - & - & - & $-.28^{* * *}$ & $.03^{* *}$ & $-.25^{* * *}$ \\
\hline & Roditeljska uključenost $\rightarrow$ Važnost predmeta $\rightarrow$ Slobodne aktivnosti učenika & - & - & - & .00 & $.02^{*}$ & $.02^{*}$ \\
\hline & $\begin{array}{l}\text { Roditeljsko pribavljanje } \rightarrow \text { Samoefikasnost učenika } \rightarrow \text { Slobodne aktivnosti } \\
\text { učenika }\end{array}$ & - & - & - & .00 & $-.02^{*}$ & $-.02^{*}$ \\
\hline
\end{tabular}

Napomena. Hipoteze prve skupine: hipoteze o neizravnoj povezanosti obrazovanja roditelja s učeničkim obrazovnim ishodima; Hipoteze druge skupine: hipoteza o neizravnoj povezanosti prošlog postignuća učenika u predmetu i kasnije samoefikasnosti u predmetu te hipoteze o neizravnoj povezanosti roditeljskih uvjerenja s učeničkim obrazovnim ishodima; Hipoteze treće skupine: hipoteze o neizravnoj povezanosti roditeljskih ponašanja s učeničkim bavljenjem aktivnostima u slobodno vrijeme. $* * * p<.001 ; * * p<.01 ; * p<.05$. 


\section{3. Provjera moderatorskih učinaka roda učenika i obrazovanja roditelja}

\section{3. 1. Provjera moderatorskog učinka roda učenika}

Kako bismo odgovorili na drugi istraživački problem, provedene su multigrupne SEM analize na način koji je opisan u potpoglavlju 3. 4. 4. dijela Metode ${ }^{31}$. U Tablici 9 prikazani su rezultati ovih analiza za modele iz matematike - indeksi pristajanja za pojedine modele s različitim razinama invarijantnosti za učenike i učenice te komparativni indeksi pristajanja koji ukazuju na rezultate testiranja razina invarijantnosti. Kao što je vidljivo iz tablice, za sva tri modela u matematici pokazalo se da postoji konfiguralna i metrijska invarijantnost modela za uzorke učenika i učenica. Strukturalna invarijantnost je potvrđena za modele s učeničkim interesom i važnosti matematike, ali ne i za model s učeničkom samoefikasnosti matematike: $\Delta \mathrm{YB} \chi^{2}(17)=30.13, p=.025$.

Kako bismo otkrili strukturalne puteve koji se statistički značajno razlikuju za uzorke učenika i učenica, koristili smo postupak u kojem se model s metrijskom invarijantnosti uspoređuje s modelom u kojem se jedan po jedan ograničavaju strukturalni putevi. Ukoliko se vrijednost razlike hi-kvadrat indeksa pokaže značajnom, možemo zaključiti da se put koji smo ograničili razlikuje u uspoređivanim skupinama. Ovaj postupak pokazao je da se modeli značajno razlikuju ukoliko se ograniči put 'roditeljska uključenost u učeničke obaveze iz matematike $\rightarrow$ učeničko bavljenje matematičkim aktivnostima': $\Delta \mathrm{YB} \chi^{2}(1)=4.76, p=.029$; put 'učeničko bavljenje matematičkim aktivnostima $\rightarrow$ učeničko postignuće iz matematike': $\Delta \mathrm{YB} \chi^{2}(1)=9.46, p=.002$ te put 'obrazovanje roditelja $\rightarrow$ učeničko postignuće iz matematike': $\Delta \mathrm{YB} \chi^{2}(1)=3.92, p=.048$.

Pregledom parametara u modelu s mjernom razinom invarijantnosti pokazalo se da roditeljska uključenost negativno predviđa bavljenje matematičkim aktivnostima u slobodno vrijeme, ali samo kod učenika $(\beta=-.16 ; p=.003)$. Kod učenica ovaj put nije bio statistički značajan $(\beta=.02 ; p=.808)$. S druge strane, frekvencija bavljenja matematičkim aktivnostima u slobodno vrijeme u modelu sa samoefikasnosti je negativno predviđala postignuće iz matematike kod učenica $(\beta=-.14 ; p<.001)$, ali ne i kod učenika $(\beta=-.03 ; p=.283)$. Također, obrazovanje roditelja izravno je predviđalo postignuće iz matematike kod učenica $(\beta=.10 ; p<$ $.001)$, ali ne i kod učenika $(\beta=.03 ; p=.149)$. Svi ostali strukturalni putevi u modelu sa samoefikasnosti su bili jednaki u slučaju učenika i učenica.

\footnotetext{
${ }^{31}$ Kako bi se ova analiza mogla valjano provesti, varijabla roda učenika, koja je u ovim analizama u ulozi moderatora, morala se najprije ukloniti kao prediktor iz modela.
} 
Tablica 9. Indeksi pristajanja SEM modela u matematici pri testiranja moderatorskog učinka roda učenika

\begin{tabular}{|c|c|c|c|c|c|c|c|c|c|c|}
\hline & & \multicolumn{6}{|c|}{ Indeksi pristajanja modela } & \multicolumn{3}{|c|}{$\begin{array}{l}\text { Komparativni indeksi } \\
\text { pristajanja }\end{array}$} \\
\hline & & YB $\chi^{2}$ & $d f$ & $\chi^{2} / d f$ & R-CFI & $\begin{array}{l}\text { R-RMSEA } \\
(90 \% \mathrm{CI})\end{array}$ & SRMR & $\Delta \mathrm{YB} \chi^{2}$ & $\Delta d f$ & $p$ \\
\hline \multirow{3}{*}{ Samoefikasnost } & Model 1 & 571.81 & 304 & 1.88 & .98 & $.042(.037-.047)$ & .044 & - & - & - \\
\hline & Model 2 & 585.97 & 314 & 1.87 & .98 & $.042(.037-.047)$ & .046 & 14.32 & 10 & .159 \\
\hline & Model 3 & 616.10 & 331 & 1.86 & .97 & $.042(.037-.047)$ & .051 & 30.13 & 17 & .025 \\
\hline \multirow{3}{*}{ Interes } & Model 1 & 627.334 & 308 & 2.04 & .97 & $.046(.041-.051)$ & .049 & - & - & - \\
\hline & Model 2 & 637.98 & 318 & 2.01 & .97 & $.045(.040-.050)$ & .050 & 10.83 & 10 & .371 \\
\hline & Model 3 & 653.81 & 333 & 1.96 & .97 & $.044(.039-.049)$ & .052 & 15.68 & 15 & .404 \\
\hline \multirow{3}{*}{ Važnost } & Model 1 & 730.48 & 306 & 2.39 & .95 & $.053(.048-.058)$ & .052 & - & - & - \\
\hline & Model 2 & 921.72 & 354 & 2.60 & .95 & $.052(.047-.057)$ & .053 & 7.18 & 10 & .709 \\
\hline & Model 3 & 757.75 & 331 & 2.29 & .95 & $.051(.046-.056)$ & .057 & 21.58 & 15 & .119 \\
\hline
\end{tabular}

Napomena. Model 1: Model s konfiguralnom invarijantnosti; Model 2: Model s metrijskom invarijantnosti; Model 3: Model sa strukturalnom invarijantnosti. 
Zatim smo pristupili testiranju razina invarijantnosti modela s obzirom na rod učenika u području tehničke kulture. Kao što je vidljivo iz Tablice 10, u sva tri modela vrijednosti razlike hi-kvadrat indeksa ukazuju na izostanak potpune metrijske invarijantnosti modela. Autori u području strukturalnog modeliranja govore o tzv. parcijalnoj metrijskoj invarijantnosti, koja je postignuta u slučaju kad su u svakom latentnom konstruktu u modelu barem dva faktorska zasićenja invarijantna u skupinama koje uspoređujemo. Ovakva se razina invarijantnosti smatra dovoljnom za opravdano uspoređivanje konstrukata među grupama (Byrne, Shavelson i Muthén, 1989). Inspekcija pojedinačnih faktorskih zasićenja, pokazala je da je ovaj uvjet zadovoljen za sve latentne konstrukte izuzev za konstrukt učeničke važnosti tehničke kulture, u kojem je samo jedno faktorsko zasićenje bilo invarijantno u skupini učenika i učenica. Stoga za model s učeničkom važnosti tehničke kulture nismo mogli testirati strukturalnu invarijantnost $\mathrm{s}$ obzirom na rod učenika. U ostala dva modela je testirana strukturalna invarijantnost te se, kao što je vidljivo iz Tablice 10, pokazalo da rod učenika ne djeluje kao moderatorska varijabla ni u modelu s učeničkom samoefikasnosti niti u modelu s učeničkim interesom za tehničku kulturu. 
Tablica 10. Indeksi pristajanja SEM modela u tehničkoj kulturi pri testiranja moderatorskog učinka roda učenika

\begin{tabular}{|c|c|c|c|c|c|c|c|c|c|c|}
\hline & & \multicolumn{6}{|c|}{ Indeksi pristajanja modela } & \multicolumn{3}{|c|}{$\begin{array}{c}\text { Komparativni indeksi } \\
\text { pristajanja }\end{array}$} \\
\hline & & YB $\chi^{2}$ & $d f$ & $\chi^{2} / d f$ & $\mathrm{R}-\mathrm{CFI}$ & $\begin{array}{c}\text { R-RMSEA } \\
(90 \% \mathrm{CI})\end{array}$ & SRMR & $\Delta \mathrm{YB} \chi^{2}$ & $\Delta d f$ & $p$ \\
\hline \multirow{3}{*}{ Samoefikasnost } & Model 1 & 1502.08 & 604 & 2.49 & .92 & $.055(.051-.058)$ & .062 & - & - & - \\
\hline & Model 2 & 1535.04 & 620 & 2.48 & .92 & $.055(.051-.058)$ & .063 & 33.52 & 16 & .006 \\
\hline & Model 3 & 1559.91 & 637 & 2.45 & .92 & $.054(.051-.057)$ & .066 & 26.13 & 17 & .072 \\
\hline \multirow{3}{*}{ Interes } & Model 1 & 1355.43 & 554 & 2.45 & .92 & $.054(.050-.058)$ & .062 & - & - & - \\
\hline & Model 2 & 1388.45 & 569 & 2.44 & .92 & $.054(.050-.057)$ & .064 & 33.22 & 15 & .004 \\
\hline & Model 3 & 1411.50 & 586 & 2.41 & .92 & $.053(.050-.057)$ & .065 & 24.08 & 17 & .117 \\
\hline \multirow{3}{*}{ Važnost } & Model 1 & 1450.63 & 552 & 2.63 & .90 & $.057(.053-.061)$ & .062 & - & - & - \\
\hline & Model 2 & 1490.29 & 567 & 2.63 & .90 & $.057(.054-.061)$ & .064 & 39.64 & 15 & .001 \\
\hline & Model 3* & 1507.12 & 584 & 2.58 & .90 & $.056(.053-.060)$ & .065 & - & - & - \\
\hline
\end{tabular}

Napomena. Model 1: Model s konfiguralnom invarijantnosti; Model 2: Model s metrijskom invarijantnosti; Model 3: Model sa strukturalnom invarijantnosti

* nije testirana strukturalna invarijantnost 


\section{3. 2. Provjera moderatorskog učinka obrazovanja roditelja}

Posljednji dio statističkih analiza odnosio se na provjeru hipoteza o moderatorskom učinku obrazovanja roditelja ${ }^{32}$. Hipoteze u ovom području nisu se odnosile na čitav strukturalni model, već samo na provjeru moderatorskog efekta obrazovanja roditelja na odnos između prethodnog učeničkog postignuća i roditeljskih uvjerenja te na odnos između roditeljskih uvjerenja i roditeljskih ponašanja. Stoga su pojedine razine invarijantnosti testirane samo za dio ukupnog modela koji uključuje ove odnose.

Prije provedbe multigrupne analize, varijabla obrazovanja roditelja je rekodirana $u$ dihotomnu varijablu s dvije kategorije koja je potom korištena kao moderator u multigrupnoj analizi. U prvu kategoriju su svrstane razine obrazovanja 'završena osnovna škola', 'završena srednja strukovna škola' i 'završena gimnazija'. U drugu kategoriju su svrstane razine obrazovanja 'završena viša škola', 'završen fakultet' te 'stečen magisterij ili doktorat znanosti'. Među roditeljima koji su ponudili odgovor na pitanje o obrazovanju, u prvoj kategoriji je bilo $58.9 \%$ roditelja $(N=603)$, a u drugoj kategoriji $41.1 \%$ roditelja $(N=421)$.

U Tablici 11 prikazani su rezultati multigrupne analize za modele u matematici $\mathrm{i}$ tehničkoj kulturi. Kao što je vidljivo, za model u matematici nije utvrđena potpuna mjerna invarijantnost u skupini nižeg i višeg roditeljskog obrazovanja. No, budući da je inspekcija pojedinačnih faktorskih zasićenja pokazala da je prisutna parcijalna mjerna invarijantnost $u$ ovim skupinama, pristupili smo provjeri strukturalne invarijantnosti. Provjereni dio modela nije bio strukturalno invarijantan u skupini nižeg i višeg obrazovanja roditelja pa smo stoga provjerili kako se model s metrijskom invarijantnosti razlikuje od modela u kojem smo osim faktorskih zasićenja, jedan po jedan ograničili svaki strukturalni put tako da bude jednak u obje skupine. Ovaj je postupak pokazao da se modeli značajno razlikuju ukoliko se ograniči put 'roditeljska uvjerenja specifična za dijete u matematici $\rightarrow$ roditeljska uključenost u djetetove obaveze iz matematike': $\Delta \mathrm{YB} \chi^{2}(1)=16.14, p<.001$ te strukturalni put 'roditeljska uvjerenja specifična za dijete u matematici $\rightarrow$ roditeljsko poticanje djetetovih interesa iz matematike': $\Delta \mathrm{YB} \chi^{2}(1)=4.71, p=.030$. Pregledom ovih parametara u modelu s metrijskom invarijantnosti je utvrđeno da su negativnija roditeljska uvjerenja bila povezana s višom uključenosti roditelja $\mathrm{u}$ obje skupine roditeljskog obrazovanja, no, u skladu s hipotezom, ta je povezanost bila snažnija kod roditelja višeg obrazovanja $(\beta=-.58 ; p<.001)$, nego kod roditelja nižeg obrazovanja $(\beta=-.36 ; p<.001)$. Također u skladu s hipotezom, roditeljska uvjerenja su bila

\footnotetext{
${ }^{32}$ Kao i u slučaju testiranja moderatorskog učinka roda učenika, i u ovim je analizama obrazovanje roditelja moralo biti isključeno kao prediktor iz modela.
} 
snažnije pozitivno povezana s roditeljskim poticanjem djetetovih interesa za matematiku u skupini više obrazovanih roditelja $(\beta=.40 ; p<.001)$ nego u skupini niže obrazovanih roditelja $(\beta=.16 ; p=.102)$. Ostali strukturalni putevi se nisu razlikovali ovisno o obrazovanju roditelja.

Nadalje smo provjerili moderatorski učinak obrazovanja roditelja u području tehničke kulture. Testiran je model koji je uključivao put između prošlog učeničkog postignuća iz tehničke kulture i roditeljskih uvjerenja te puteve između roditeljskih uvjerenja i roditeljskog poticanja interesa te roditeljskih uvjerenja i roditeljskog pribavljanja STEM materijala. Kao što je vidljivo iz Tablice 11, konfiguralni model je imao loše RMSEA i CFI indekse pristajanja, no budući da omjer hi-kvadrat vrijednosti i stupnjeva slobode nije prelazio graničnu vrijednost od 5, interval pouzdanosti RMSEA indeksa nije prelazio graničnu vrijednost od .10, a SRMR indeks je imao prihvatljivu vrijednost, ovaj je model prihvaćen. Nadalje se pokazalo da model nije metrijski invarijantan u skupini niže i više obrazovanih roditelja (Tablica 11). Međutim, dodatnim je analizama utvrđeno da su svi latentni konstrukti obuhvaćeni provjerenim modelom parcijalno invarijantni u dvije skupine obrazovanja roditelja te je stoga provjerena strukturalna invarijantnost modela. Kao što je vidljivo iz Tablice 11, nisu utvrđene razlike u strukturalnim putevima u skupinama višeg i nižeg obrazovanja roditelja. 
Tablica 11. Indeksi pristajanja SEM modela u matematici i tehničkoj kulturi pri testiranja moderatorskog učinka obrazovanja roditelja

\begin{tabular}{|c|c|c|c|c|c|c|c|c|c|c|}
\hline & & \multicolumn{6}{|c|}{ Indeksi pristajanja modela } & \multicolumn{3}{|c|}{$\begin{array}{l}\text { Komparativni indeksi } \\
\text { pristajanja }\end{array}$} \\
\hline & & YB $\chi^{2}$ & $d f$ & $\chi^{2} / d f$ & $\mathrm{R}-\mathrm{CFI}$ & $\begin{array}{l}\text { R-RMSEA } \\
(90 \% \mathrm{CI})\end{array}$ & SRMR & $\Delta \mathrm{YB} \chi^{2}$ & $\Delta d f$ & $p$ \\
\hline \multirow{3}{*}{ Matematika } & Model 1 & 222.15 & 70 & 3.16 & .962 & $.066(.057-.076)$ & .053 & - & - & - \\
\hline & Model 2 & 236.75 & 75 & 3.16 & .960 & $.066(.057-.076)$ & .056 & 14.63 & 5 & .012 \\
\hline & Model 3 & 264.86 & 83 & 3.19 & .955 & $.067(.058-.076)$ & .065 & 28.22 & 8 & $<.001$ \\
\hline \multirow{3}{*}{ Tehnička kultura } & Model 1 & 353.75 & 78 & 4.54 & .882 & $.085(.076-.095)$ & .058 & - & - & - \\
\hline & Model 2 & 370.18 & 84 & 4.41 & .876 & $.084(.076-.093)$ & .061 & 17.93 & 6 & .006 \\
\hline & Model 3 & 374.28 & 90 & 4.16 & .877 & $.081(.073-.090)$ & .063 & 3.77 & 6 & .708 \\
\hline
\end{tabular}

Napomena. Model 1: Model s konfiguralnom invarijantnosti; Model 2: Model s metrijskom invarijantnosti; Model 3: Model sa strukturalnom invarijantnost 


\section{RASPRAVA}

Nalazi vezani uz prvi problem ovog istraživanja bit će raspravljeni u cjelinama koje se odnose na pojedine vrste ispitanih roditeljskih utjecaja (obrazovanje roditelja, roditeljska uvjerenja i roditeljska ponašanja). Nalazi koji se odnose na drugi istraživački problem bit će raspravljeni u cjelinama koje predstavljaju dva dijela tog problema (ispitivanje moderatorskog učinka roda učenika i obrazovanja roditelja). Unutar svakog dijela rasprave, usporedit ćemo nalaze dobivene u modelima iz matematike i iz tehničke kulture. Kao i u uvodu ovog rada, pri referiranju na prošla istraživanja prvenstveno ćemo se osloniti na prijašnje nalaze u matematici ili prirodnim predmetima budući da nismo pronašli istraživanja koja su se bavila ispitanim odnosima u tehničkom obrazovanju.

\section{1. Uloga obrazovanja roditelja u objašnjenju učeničkih obrazovnih ishoda u matematici i tehničkoj kulturi}

Hipoteze vezane uz ulogu obrazovanja roditelja u objašnjavanju učeničkih obrazovnih ishoda većim dijelom nisu naišle na podršku u ovom istraživanju. U matematici ove hipoteze u cijelosti nisu potvrđene, dok su u tehničkoj kulturi dobile djelomičnu potvrdu. Razlog tome je što pojedine izravne veze koje su uključene u hipoteze o neizravnom učinku obrazovanja roditelja na učeničko postignuće i samoefikasnost u matematici i tehničkoj kulturi nisu bile značajne. Najprije ćemo razmotriti nalaze vezane uz medijacijsku ulogu roditeljskih uvjerenja, a potom uz medijacijsku ulogu roditeljskih ponašanja u objašnjavanju poveznice između obrazovanja roditelja i učeničkih obrazovnih ishoda u matematici i tehničkoj kulturi.

\section{1. 1. Medijacijska uloga roditeljskih uvjerenja}

Suprotno očekivanjima, obrazovanje roditelja nije bilo povezano s roditeljskim uvjerenjima specifičnim za dijete u matematici. Na bivarijatnoj razini ta je korelacija, u skladu s očekivanjem, bila pozitivna i značajna, no u strukturalnom modelu je ona postala neznačajna kada je u obzir uzeto i prošlo postignuće učenika iz matematike. Naime, prošlo postignuće iz matematike je bilo umjereno pozitivno povezano s obrazovanjem roditelja te $u$ vrlo visokoj pozitivnoj korelaciji s roditeljskim uvjerenjima specifičnim za dijete u matematici. Rezultat dobiven u SEM modelu, kada su u obzir uzete sve tri varijable, sugerira da se bivarijatna korelacija između obrazovanja roditelja i roditeljskih uvjerenja u potpunosti može pripisati 
korelaciji obje ove varijable s višim prošlim postignućem učenika iz matematike. Drugim riječima, kada su učenici izjednačeni po svom postignuću iz matematike, obrazovaniji roditelji nemaju pozitivnija uvjerenja specifična za dijete u matematici od manje obrazovanih roditelja.

U nekim prethodnim istraživanjima u STEM području povezanost između višeg roditeljskog SES-a i pozitivnijih roditeljskih uvjerenja vezanih uz dijete je ipak pronađena (npr. Davis-Kean, 2005; Long i Pang, 2016; Svoboda i sur., 2016). Međutim, u ovim istraživanjima nije kontrolirano prethodno postignuće učenika. Naši rezultati sugeriraju da je prošlo postignuće učenika u matematici moguća konfundirajuća varijabla koju je važno uzeti u obzir pri ispitivanju ove veze.

Možemo zaključiti da u višim razredima osnovne škole roditelji svoja uvjerenja specifična za dijete u matematici u velikoj mjeri formiraju na temelju vanjske informacije o djetetovom prošlom uspjehu u ovom predmetu, a obrazovanje roditelja nema nezavisni doprinos u oblikovanju tih uvjerenja. Istraživanja pokazuju da povratne informacije iz škole imaju značajno korektivno djelovanje na roditeljska uvjerenja o djetetu (Eccles, 1993; Entwisle i Hayduk, 1978). Budući da je matematika jedan od najvažnijih predmeta tijekom čitavog osnovnog i srednjeg školovanja, i djeca i roditelji primaju redovne i istaknute povratne informacije o djetetovu napretku u matematici. Stoga je za očekivati da su pri kraju osnovnog školovanja roditelji već stvorili unutarnju sliku o svom djetetu i njegovim sposobnostima i afinitetu za matematiku te da je ta slika dominantno pod utjecajem upravo povratnih informacija iz škole. Prijašnja istraživanja također pokazuju da su najistaknutiji izvor informacija na kojima roditelji grade svoja uvjerenja o djetetovim sposobnostima u matematici upravo školske ocjene (Möller, Zimmermann i Köller, 2014; Tiedemann, 2000) i da je veza između roditeljskih uvjerenja o djetetu i ocjena snažnija u matematici nego u drugim predmetima kao što su, primjerice, jezici (Gniewosz, Eccles i Noack, 2015).

Zanimljivo bi bilo ispitati odnos između SES-a i roditeljskih uvjerenja u matematici kod roditelja mlađe djece koja su tek na početku školovanja. Budući da je u ranijim fazama razvoja djeteta i opseg vanjskih povratnih informacija o djetetovim sposobnostima manji, moguće je da roditeljske osobne dispozicije, kao što je stupanj obrazovanja, imaju veću ulogu pri oblikovanju roditeljskih uvjerenja i očekivanja vezanih uz djetetov obrazovni put u matematici. Primjerice, u istraživanju kojeg su proveli DeFlorio i Beliakoff (2015) roditelji višeg SES-a su imali značajno viša očekivanja o matematičkim sposobnostima petogodišnje djece nego roditelji nižeg SES-a.

Za razliku od matematike, u SEM modelima iz tehničke kulture obrazovanje roditelja je bilo negativno povezano s roditeljskim uvjerenjima u ovom predmetu, što je neočekivan nalaz. 
Na bivarijatnoj razini ove su dvije varijable bile nepovezane, no dodatne su analize sugerirale da prošlo učeničko postignuće iz tehničke kulture "maskira" tu povezanost. Naime, kada smo u SEM modelu simultano u obzir uzeli i prošlo postignuće učenika i obrazovanje roditelja, mogli smo dobiti uvid samo u onaj dio varijance roditeljskih uvjerenja kojeg obrazovanje roditelja objašnjava nezavisno od stvarnog postignuća učenika. Upravo je taj dio povezanosti obrazovanja i uvjerenja roditelja bio negativan. Drugim riječima, kada su učenici izjednačeni po svom prošlom postignuću iz tehničke kulture, obrazovaniji roditelji imaju nešto negativnija uvjerenja specifična za dijete u ovom predmetu.

Također, u konačnom SEM modelu obrazovanje roditelja je imalo u potpunosti negativan neizravan učinak na učeničku samoefikasnost u tehničkoj kulturi koji se ostvarivao, kao što je i očekivano, preko roditeljskih uvjerenja. Dakle, obrazovaniji roditelji imaju nešto negativnija uvjerenja specifična za dijete u tehničkoj kulturi koja su povezana s kasnijom nižom učeničkom samoefikasnosti u ovom predmetu ${ }^{33}$. U konačnim SEM modelima je također utvrđeno da je razina obrazovanja roditelja bila izravan negativan prediktor učeničkog interesa i važnosti tehničke kulture. Općenito, ovi nalazi upućuju na zaključak da kad u obzir uzmemo stvarno učeničko postignuće, učenici čiji su roditelji obrazovaniji pokazuju nešto nižu motivaciju u području tehničke kulture od učenika čiji su roditelji manje obrazovani. S druge strane, u matematici su kod učenika obrazovanijih roditelja sva tri motivacijska uvjerenja bila značajno viša (iako se ta korelacija izgubila u konačnim SEM modelima, kada su u obzir uzete i ostale roditeljske i učeničke varijable).

Objašnjenje nalaza vezanih uz utjecaj obrazovanja roditelja u modelima iz tehničke kulture potrebno je potražiti kroz razmatranje šireg obrazovnog i profesionalnog konteksta $\mathrm{u}$ Hrvatskoj unutar kojeg možemo smjestiti ovaj školski predmet. U Hrvatskoj, kao i u mnogim drugim zemljama, srednjoškolsko obrazovanje je moguće razdvojiti u dvije glavne kategorije gimnazijsko, odnosno opće srednjoškolsko obrazovanje koje se percipira kao priprema za upis na fakultet te strukovno obrazovanje koje učenike obučava za konkretna zanimanja. U kontekstu ovih obrazovnih puteva, u Hrvatskoj je postignuće iz tehničke kulture u osnovnoj školi relevantno samo za upis u pojedine strukovne srednje škole (MZO, 2013). Isto tako, tehničko-tehnološki nastavni predmeti se u Hrvatskoj provode isključivo u strukovnim srednjim školama. Iz ovih razloga je moguće da roditelji i djeca u Hrvatskoj tehničku kulturu u osnovnoj

\footnotetext{
${ }^{33} \mathrm{U}$ modelima iz tehničke kulture pronađena su još dva značajna, ali vrlo niska neizravna efekta obrazovanja roditelja: neizravan učinak na učeničko postignuće preko negativnijih roditeljskih uvjerenja $(\beta=-.01 ; p=.015)$ te neizravan učinak na učeničku samoefikasnost preko većeg roditeljskog pribavljanja STEM materijala $(\beta=-.01 ; p$ $=.022$ ). Međutim, budući da su oba ova efekta izrazito niska, kao i izravne veze koje su u njih uključene, ovi se učinci u praktičnom smislu mogu smatrati zanemarivima te ih stoga nećemo posebno komentirati.
} 
školi percipiraju kao predmet koji ima svoju ulogu isključivo unutar užeg puta strukovnog obrazovanja za tehnička zanimanja.

$\mathrm{S}$ druge strane, poznato je da u zapadnom društvu strukovno srednjoškolsko obrazovanje ima manji socijalni prestiž od općeg srednjoškolskog obrazovanja (Meer, 2007), a akademsko znanje se stavlja u superioran odnos naspram stjecanja praktičnih znanja i vještina (Young, 1998). U skladu s time, istraživanja pokazuju da djeca koja dolaze iz obitelji višeg SES-a imaju značajno niže aspiracije prema radničkim zanimanjima (engl. blue collar workers) koja se stječu strukovnim obrazovanjem, a značajno više opće obrazovne aspiracije (Dubow, Boxer i Huesmann, 2009; Eccles, Vida i Barber, 2004). Isto tako, obrazovaniji roditelji, u usporedbi s manje obrazovanim roditeljima, u većoj mjeri usmjeravaju svoju djecu prema općem srednjoškolskom obrazovanju budući da ono predstavlja najbolju pripremu za kasniji upis na fakultete (Meer, 2007). Ovi bi nalazi objasnili zašto su u našem istraživanju učenici obrazovanijih roditelja izvijestili o nižoj motivaciji za tehničku kulturu, a njihovi roditelji o negativnijim uvjerenjima vezanim uz svoju djecu u ovom predmetu. Naime, kao što je prethodno opisano, u kontekstu obrazovnih tranzicija predmet tehničke kulture u Hrvatskoj ima značaj samo za ulaz u strukovno obrazovanje, a to je obrazovna opcija koja je značajno manje privlačna djeci i roditeljima višeg SES-a.

\section{1. 2. Medijacijska uloga roditeljskih ponašanja}

Medijacijska uloga roditeljskih ponašanja u ispitivanju poveznice između obrazovanja roditelja i učeničke samoefikasnosti nije potvrđena, iako je u konačnim modelima obrazovanje roditelja djelomično predviđalo roditeljska ponašanja. U ovom ćemo poglavlju razmotriti samo direktne poveznice između obrazovanja roditelja i roditeljskih ponašanja, dok će dio nalaza koji se odnosi na vezu između pojedinačnih roditeljskih ponašanja i učeničkih obrazovnih ishoda bit detaljnije raspravljen u poglavlju 5. 3.

Prema postavljenoj hipotezi, bilo je očekivano da će obrazovanje roditelja predviđati veće roditeljsko pribavljanje STEM materijala, kao i češće poticanje djetetovih interesa u matematičkom i tehničkom području. I u modelu iz matematike i tehničke kulture više obrazovanje roditelja je predviđalo veće roditeljsko pribavljanje STEM materijala za dijete. Pozitivna veza između SES-a i dostupnosti materijala koji stimuliraju učenje u domu djeteta pronađena je i u prethodnim istraživanjima (Duncan i Magnuson, 2005; Parcel i Menaghan, 1990; Starkey i Klein, 2008). Međutim, u našem istraživanju razina pribavljanja STEM materijala nije previđala učeničku samoefikasnost u matematici zbog čega pretpostavljeni 
medijacijski efekt nije ostvaren. U modelu iz tehničke kulture je utvrđena vrlo niska negativna povezanost između pribavljanja STEM materijala i učeničke samoefikasnosti. Međutim, imajući u vidu veličinu ove povezanosti, kao i nalaz da je ona na bivarijatnoj razini bila nulta, ovaj medijacijski efekt nećemo razmatrati kao značajan.

Regresijski put između obrazovanja roditelja i roditeljskog poticanja učeničkih interesa u modelima iz tehničke kulture bio je pozitivan (ali vrlo nizak), no medijacijski efekt nije potvrđen budući da poticanje interesa nije predviđalo učeničku samoefikasnost. U matematici obrazovanje roditelja nije predviđalo roditeljsko poticanje. Slično našim nalazima, Davis-Kean (2005) većim dijelom nije uspjela potvrditi medijacijski utjecaj roditeljskih ponašanja $u$ objašnjavanju pozitivne povezanosti između SES-a i učeničkog postignuća u matematici i čitanju na uzorku obitelji europsko-američkog podrijetla. Ispitivana ponašanja u ovom istraživanju nisu bila specifična za STEM područje, već su uključivala opće roditeljske prakse (čitanje, igranje s djetetom i toplinu roditeljskih interakcija). Davis-Kean (2005) stoga navodi da istraživanja trebaju ispitati dodatne bihevioralne mehanizme koji bi mogli objasniti neizravni efekt SES-a na učeničke obrazovne ishode.

Na temelju naših rezultata ipak ne možemo donijeti zaključak da razina obrazovanja roditelja nije povezana ili da je vrlo slabo povezana s podržavajućim ponašanjima roditelja $u$ STEM području. Kao što će ponovno biti riječi na nekoliko mjesta u narednim poglavljima, treba imati na umu da smo ovim istraživanjem obuhvatili samo neka roditeljska ponašanja te da su sve korištene mjere usmjerene na učestalost, a ne na kvalitetu tih ponašanja. Tako je moguće da nismo obuhvatili podržavajuća ponašanja za koja se mogu otkriti razlike između više i manje obrazovanih roditelja $\mathrm{i} / \mathrm{ili}$ da nismo koristili odgovarajuće mjere ispitanih ponašanja koje bi ukazale na razlike povezane sa SES-om. Primjerice, u istraživanju koje su proveli Hyde i suradnici (2017) obrazovanije majke su prilikom komunikacije s djetetom o različitim STEM područjima u većoj mjeri elaborirale korisnost tih područja, a pritom je korištena kvalitativna mjera majčine elaboracije. U drugom su istraživanju tijekom posjeta znanstvenom centru obrazovaniji roditelji dulje razgledavali izloške sa svojom djecom i pritom češće povezivali sadržaj izložaka s prethodnim iskustvom (Szechter i Carey, 2009).

U objašnjenju dobivenih nalaza treba uzeti u obzir i dob našeg uzorka učenika. Naime, za očekivati je da se stupanj obrazovanja roditelja više odražava u kognitivno stimulirajućim roditeljskim ponašanjima koja su zastupljena pri odgoju mlađe djece koja još nisu krenula u školu. Takva ponašanja kod predškolske djece, primjerice, razvijaju osnovne numeričke i spacijalne vještine, a uključuju aktivnosti kao što je zbrajanje i oduzimanje s djetetom pri svakodnevnim situacijama kao što je kupovina, poticanje djeteta da opisuje oblik, smjer 
kretanja ili položaj stvari u prostoru, zajedničko prebrojavanje roditelja i djeteta, razgovor o novcu i igranje igara na ploči (LeFevre i sur., 2009; Levine, Suriyakham, Rowe, Huttenlocher i Gunderson, 2010; Pan, Yang, Li, Liu i Liu, 2018; Verdine, Irwin, Golinkoff i Hirsh-Pasek, 2014). U nedavnom su istraživanju ovakve rane numeričke i spacijalne aktivnosti ispitane kod roditelja četverogodišnje djece. U skladu s očekivanjem, obrazovaniji roditelji su značajno češće provodili ove aktivnosti od manje obrazovanih roditelja (Pan i sur., 2018).

Istraživanja također pokazuju da je SES više povezan s aktivnostima u koje su roditelji uključeni u školi, nego s aktivnostima izvan škole (Green, Walker, Hoover-Dempsey i Sandler, 2007; Grolnick, Benjet, Kurowski i Apostoleris, 1997; Grolnick i Slowiaczek, 1994; Pomerantz i sur., 2007). Takva roditeljska ponašanja, primjerice, uključuju prisustvovanje na roditeljskim sastancima, komunikaciju s nastavnicima, uključenost u aktivnosti škole i roditeljsko volontiranje u školi (Epstein i Sanders, 2002; Fan i Chen, 2001; Hill i Tyson, 2009). Stoga bi bihevioralni medijacijski efekti možda bili potvrđeni da smo ispitali ovakav tip roditeljskih ponašanja.

$\mathrm{Na}$ kraju ovog dijela rasprave treba napomenuti da, iako u konačnim modelima iz matematike obrazovanje roditelja nije potvrđeno ni kao izravan ni kao neizravan prediktor učeničkih obrazovnih ishoda, ti nalazi ne impliciraju da je obrazovanje roditelja nepovezano s učeničkim obrazovnim ishodima u matematici. Naime, iz bivarijatne korelacijske matrice je vidljivo da je obrazovanje roditelja pozitivno povezano sa sva tri motivacijska uvjerenja te postignućem učenika u matematici. Prošla istraživanja su također potvrdila slabu do umjerenu pozitivnu povezanost između SES-a i učeničkog postignuća u matematici (npr. Huang i Liang, 2016; OECD, 2007; Sirin, 2005), kao i povezanost između SES-a i viših motivacijskih uvjerenja u ovom predmetu (npr. Svoboda i sur., 2016). Međutim, naše istraživanje pokazuje da kada se u obzir uzme auto-korelacijski efekt učeničkog postignuća iz prethodne školske godine koje također predviđa i kasnija učenička motivacijska uvjerenja u matematici te je povezano s obrazovanjem roditelja, obrazovanje roditelja više nema nezavisan doprinos u objašnjavanju učeničkih obrazovnih ishoda u matematici. 


\section{2. Uloga roditeljskih uvjerenja u objašnjenju učeničkih obrazovnih ishoda u matematici i tehničkoj kulturi}

\section{2. 1. Roditeljska uvjerenja kao prediktori učeničkih motivacijskih uvjerenja}

U skladu s postavljenim hipotezama, roditeljska uvjerenja potvrđena su kao značajni, umjereni do snažni prediktor svih učeničkih motivacijskih uvjerenja i u matematici i u tehničkoj kulturi. I veliki broj prijašnjih istraživanja je pokazao da roditeljska uvjerenja vezana uz dijete značajno predviđaju i učenička uvjerenja o sposobnosti i učeničke vrijednosti zadatka u STEM školskim predmetima (Bhanot i Jovanovic, 2009; Bleeker i Jacobs, 2004; Dickhäuser i Stiensmeier-Pelster, 2003; Eccles, 1993; Eccles i sur., 1982; Fan i Williams, 2010; Froiland i Davison, 2016; Frome i Eccles, 1998; Gladstone i sur., 2018; Gniewosz i sur., 2015; Jacobs, 1991; Jacobs i Eccles, 1992; Stevenson i Newman, 1986).

$\mathrm{U}$ našem je istraživanju u oba predmeta prediktivni učinak roditeljskih uvjerenja $\mathrm{u}$ objašnjavanju učeničke samoefikasnosti u predmetu bio snažniji od učinka stvarnog prošlog postignuća učenika u predmetu. Drugim riječima, roditeljske evaluacije djeteta u predmetu imaju nezavisnu ulogu u oblikovanju djetetove slike u sebi u matematici i tehničkoj kulturi i te su evaluacije važniji izvor informacija na kojima djeca grade pojam o sebi u predmetu nego djetetov stvarni uspjeh. Ovakav nalaz dobiven je i u prošlim istraživanjima u matematici (Eccles i sur., 1982; Entwisle i Baker, 1983; Fredricks i Eccles, 2002; Frome i Eccles, 1998; Jacobs, 1991; Phillips, 1987). Bhanot i Jovanovic (2009) su umjesto prethodnog postignuća kontrolirali prethodna učenička motivacijska uvjerenja u prirodoslovlju te su pokazali da čak i uz kontrolu tih uvjerenja, majčina uvjerenja o sposobnostima djeteta u prirodoslovlju nezavisno predviđaju kasnije učenička motivacijska uvjerenja.

Bleeker i Jacobs (2004) su pronašle i dugoročan efekt roditeljskih uvjerenja. U njihovom su istraživanju majčina očekivanja djetetove uspješnosti u karijeri vezanoj uz matematiku pozitivno predviđala učeničku samoefikasnost u matematici tri godine kasnije, kao i samoefikasnost u karijerama vezanim uz matematiku i prirodoslovlje u dobi između 24 i 25 godina. Fredricks i Eccles (2002) su u svom longitudinalnom istraživanju pratile učenike od njihove sedme do 18. godine te utvrdile značajan pad u učeničkim uvjerenjima o vlastitoj sposobnosti u matematici. Međutim, ovaj je pad bio manje izražen kod učenika čiji su roditelji imali inicijalna uvjerenja o višoj djetetovoj sposobnosti u matematici čak i kad su u obzir uzete različite mjere matematičkog postignuća učenika u nižim razredima osnovne škole. Nedavno je istraživanje (Gniewosz i Watt, 2017) pokazalo da i kad roditelji precjenjuju djetetove 
sposobnosti u matematici to pozitivno predviđa promjenu u interesu i percepciji korisnosti matematike kod adolescenata. Međutim, autori navode da je moguće da ta veza nije posve linearna, odnosno, da roditeljska uvjerenja koja su nerealistično pozitivna mogu imati suprotni efekt na učeničku motivaciju. Ipak, opisani nalazi, kao i nalazi našeg istraživanja, jasno ilustriraju važnost pozitivnih roditeljskih očekivanja i uvjerenja vezanih uz dijete u STEM akademskom području.

Pored toga što su roditeljska uvjerenja bila značajan prediktor učeničke motivacije i u matematici i u tehničkoj kulturi, u oba je predmeta zabilježen značajan medijacijski efekt ovih roditeljskih uvjerenja u objašnjavanju veze između učeničkog prošlog postignuća i kasnije samoefikasnosti u predmetu. Ova veza, koja proizlazi iz modela roditeljske socijalizacije dječjih obrazovnih ishoda, pronađena je i u prijašnjim istraživanjima u matematici (Frome $\mathrm{i}$ Eccles, 1998; Gniewosz i sur., 2015; Jacobs i Eccels, 1992) te potvrđuje tezu o roditeljima kao "tumačima stvarnosti". Ova roditeljska uloga znači da su djetetove percepcije vlastitih sposobnosti utemeljene ne samo na objektivnoj informaciji o dosadašnjem uspjehu u nekom području, već i na roditeljskim subjektivnim interpretacijama te stvaranosti (Frome i Eccles, 1998; Jacobs i Eccles, 2000).

\section{2. 2. Roditeljska uvjerenja kao prediktori učeničkog postignuća}

U ovom su istraživanju roditeljska uvjerenja potvrđena kao značajni prediktori kasnijeg postignuća iz matematike uz kontrolu i učeničkih motivacijskih uvjerenja i prethodnog postignuća iz matematike. U tehničkoj kulturi su roditeljska uvjerenja imala rubno značajan efekt u predviđanju postignuća, što se vjerojatno može pripisati vrlo niskom varijabilitetu učeničkih ocjena iz tehničke kulture, ali i niskom varijabilitetu roditeljskih uvjerenja specifičnih za dijete u ovom predmetu.

I u prošlim su se istraživanjima roditeljska uvjerenja i očekivanja djetetovog uspjeha u matematici pokazala kao značajni prediktori kasnijeg učeničkog postignuća iz matematike čak i uz kontrolu prethodnog učeničkog postignuća (Aunola i sur., 2003; Gill i Reynolds, 1999; Halle i sur., 1997). Pokazalo se i da vrlo rana roditeljska uvjerenja mogu imati dugoročne učinke na učeničko postignuće. Primjerice, Hess, Holloway, Dickson i Price (1985) su ispitali matematičko postignuće učenika šestih razreda osnovne škole kontrolirajući pritom njihovu prethodnu matematičku sposobnost. Učenici čije su majke još za vrijeme vrtića imale viša očekivanja djetetovog matematičkog postignuća postizali su više rezultate $u$ matematici $u$ šestom razredu osnovne škole u odnosu na učenike čije su majke imale niža očekivanja. 
Zanimljivo je da je u našem istraživanju u oba predmeta od tri motivacijska uvjerenja samo učenička samoefikasnost u predmetu imala medijacijsku ulogu u objašnjavanju poveznice između roditeljskih uvjerenja i kasnijeg učeničkog postignuća iz predmeta. To je zato što ni u matematici ni u tehničkoj kulturi učenički interes za predmet i važnost predmeta nisu bili značajni prediktori postignuća. U skladu s time, postignuće učenika iz prethodne školske godine je predviđalo samo kasniju učeničku samoefikasnost u predmetu, ali ne i komponente subjektivne vrijednosti zadatka, i u matematici i u tehničkoj kulturi. Ovi su nalazi na tragu ranijih razmatranja o različitoj ulozi učeničkih uvjerenja o vlastitim sposobnostima i učeničkih vrijednosti u predviđanju različitih oblika obrazovnih ishoda. Istraživanja, naime, sugeriraju da su uvjerenja o sposobnostima snažnije povezana s obrazovnim postignućem (Eccles i sur., 1983; Wigfield, 1994; Wigfield i Eccles, 1992), dok je subjektivna vrijednost zadatka snažnije povezana s obrazovnim planovima i obrazovnim odabirima učenika (Eccles i sur., 2005).

Primjerice, na uzorku učenika u dobi između 14 i 16 godina samo je učenička samoefikasnost u matematici bila povezana s kasnijim učeničkim ocjenama iz matematike, ali ne i subjektivna vrijednost zadatka (Eccles i sur., 1984). Lazardis i Ittel (2013) su također dobile da interes za matematiku kod učenika u dobi od oko 15 godina nije predviđao postignuće iz matematike. U istraživanju kojeg su proveli Greene, DeBacker, Ravindran i Krows (1999) očekivanje uspjeha bilo je snažnije povezano s postignućem iz matematike kod srednjoškolaca, dok je subjektivna vrijednost zadatka bila snažnije povezana s ulaganjem truda. Dinkelmann i Buff (2016) su pokazali da su u šestom razredu osnovne škole samo učenička uvjerenja o sposobnosti u matematici, ali ne i interes za matematiku, predviđala učeničko postignuće $u$ matematici. U skladu s tim, indirektni efekt roditeljske podrške u matematici na učeničko postignuće ostvaren je samo preko učeničkih uvjerenja o sposobnosti, a ne i preko interesa. Prijašnja su istraživanja (Marsh, Köller, Trautwein, Lüdtke i Baumert, 2005; Meece i sur., 1990; Spinath, Spinath, Harlaar i Plomin, 2006) također pokazala da učenička uvjerenja o sposobnosti u matematici predviđaju postignuće iz ovog predmeta čak i uz kontrolu prethodnog postignuća ili inteligencije učenika, što je u skladu s našim nalazima u oba predmeta.

$\mathrm{U}$ našem je istraživanju u modelima iz matematike pored neizravnog efekta roditeljskih uvjerenja na postignuće preko učeničke samoefikasnosti, pronađen i izravan efekt roditeljskih uvjerenja na postignuće. Iako prema modelu roditeljske socijalizacije dječjih obrazovnih ishoda roditeljska uvjerenja predviđaju učeničko postignuće prvenstveno neizravno, preko utjecaja na učenička motivacijska uvjerenja (Eccles, 2005), naši su nalazi u skladu s novijim istraživanjima u matematici u kojima je taj efekt također bio i direktan (Froiland i Davison, 2016; Froiland i sur., 2013; Kung i Lee, 2016; Neuenschwander i sur., 2007). Buduća bi istraživanja stoga 
trebala ispitati dodatne motivacijske, kognitivne, afektivne i ponašajne ishode kod djeteta, pored motivacijskih uvjerenja koja proizlaze iz teorije očekivanja i vrijednosti, koji bi mogli objasniti kako roditeljska uvjerenja neizravno utječu na učeničko postignuće.

\section{2. 3. Medijacijska uloga roditeljskih ponašanja}

Ispitivanim je modelima bilo predviđeno da će roditeljska uvjerenja specifična za dijete u matematici i tehničkoj kulturi biti povezana s roditeljskim ponašanjima u ovim područjima. Pobliže, bilo je očekivano da će roditeljska uvjerenja biti pozitivno povezana s roditeljskim poticanjem interesa u području matematike i tehničke kulture i roditeljskim pribavljanjem materijala za dijete u ovim područjima, dok je očekivana negativna povezanost s roditeljskom uključenosti u učeničke obaveze iz predmeta. Ove hipoteze su gotovo u cijelosti potvrđene u modelima iz oba predmeta. Izuzetak je izostanak poveznice između roditeljskih uvjerenja i roditeljske uključenosti u učeničke obaveze iz tehničke kulture, što se vjerojatno može pripisati tome da je ovo ponašanje u tehničkoj kulturi bilo rijetko.

Bez obzira na to što su roditeljska uvjerenja bila značajni prediktori roditeljskih ponašanja, hipoteza o medijacijskoj ulozi roditeljskih ponašanja u objašnjenju povezanosti između roditeljskih uvjerenja i učeničkih motivacijskih uvjerenja većinom nije potvrđena. Ova je hipoteza potvrđena $\mathrm{u}$ modelu s učeničkim interesom za matematiku u kojem su rjeđa roditeljska uključenost u obaveze iz matematike te češće poticanje djetetovih interesa za matematiku imali ulogu medijatora u objašnjavanju dijela poveznice 'roditeljska uvjerenja učenički interes ${ }^{134}$. Dobiveni nalazi stoga sugeriraju da ispitana roditeljska ponašanja većinom ne djeluju kao mehanizmi preko kojih djeca internaliziraju roditeljska uvjerenja o njihovim sposobnostima i afinitetu za matematiku i tehničku kulturu. Izostanak medijacijskog efekta se u većini slučajeva može pripisati činjenici da roditeljska ponašanja uključenosti, poticanja interesa i pribavljanja materijala nisu predviđala učenička motivacijska uvjerenja vezana uz matematiku i tehničku kulturu, što će detaljnije, za svako ponašanje pojedinačno, biti raspravljeno u sljedećem poglavlju.

Prošla istraživanja također ukazuju da model roditeljske socijalizacije dječjih obrazovnih ishoda Eccles i suradnika ne dobiva dovoljno podrške upravo u dijelu koji se odnosi

\footnotetext{
${ }^{34}$ Pronađen je i vrlo mali neizravni efekt roditeljskih uvjerenja na učeničku samoefikasnost u tehničkoj kulturi preko roditeljskog pribavljanja materijala $(\beta=-.01 ; p=.022)$. Međutim, osim što je ovaj neizravni učinak bio vrlo mali i rubno značajan, negativni izravan učinak roditeljskog pribavljanja materijala na učeničku samoefikasnost $u$ tehničkoj kulturi je također vrlo mali $(\beta=-.07 ; p=.002$ ), a na bivarijatnoj razini je nulti (ovaj nalaz već je spomenut u prethodnoj fusnoti). Iz ovih razloga, ovi neizravni efekti roditeljskih uvjerenja nisu posebno raspravljeni.
} 
na roditeljske bihevioralne medijacijske mehanizme. U razmatranju dotadašnjih nalaza vezanih uz empirijsku provjeru modela, Eccels (1993) je zaključila da istraživanja ne uspijevaju identificirati bihevioralne mehanizme preko kojih roditeljska uvjerenja djeluju na učeničku samoefikasnost te da je taj odnos $u$ istraživanjima najčešće direktan. U području STEM obrazovanja, nalaz vrlo sličan našem dobiven je u istraživanju Simpkins i suradnica (2012). U tom su istraživanju majčina ponašanja vezana uz matematiku imala medijacijsku ulogu samo u objašnjenju poveznice između majčinih uvjerenja specifičnih za dijete u matematici i djetetove vrijednosti matematike, ali ne i u objašnjenju poveznice između majčinih uvjerenja i djetetove samoefikasnosti u matematici. Kao i u našem istraživanju, potonji se medijacijski efekt pokazao neznačajnim upravo zato što majčina ponašanja nisu bila prediktor učeničke samoefikasnosti. U istraživanju kojeg su proveli Bhanot i Jovanovic (2009) roditeljska ponašanja u području prirodoslovlja također nisu imala medijacijski učinak u objašnjenju poveznice između roditeljskih uvjerenja vezanih uz prirodoslovlje i učeničkih motivacijskih uvjerenja u ovom školskom predmetu.

Imajući u vidu naše nalaze te nalaze prošlih istraživanja, postavlja se pitanje koji su to bihevioralni mehanizmi preko kojih učenici internaliziraju roditeljske evaluacije u STEM obrazovnom području? Moguće je da ponašanja koja smo ispitali u ovom istraživanju u stvarnosti imaju medijacijsku ulogu, no korištena metodologija ne omogućava potvrdu te hipoteze budući da nam ne daje uvid u kvalitetu, već isključivo učestalost ispitanih ponašanja. Eccles (2007) navodi da socijalizacijski potencijal roditeljskih ponašanja uvelike ovisi o motivacijskoj i emocionalnoj klimi koju roditelji stvaraju u interakcijama s djetetom. Prošla istraživanja tako sugeriraju da roditeljska kontrola, struktura i toplina mogu imati ulogu u objašnjavanju učeničkih obrazovnih ishoda u STEM području.

Roditeljska kontrola je jedna od najvažnijih kvalitativnih odlika roditeljskih ponašanja (Pomerantz i Grolnick, 2009). Roditeljska ponašanja koja su visoko kontrolirajuća karakterizira pritisak, intruzija i dominacija nad djetetom (Pomerantz i Grolnick, 2009). Visoka roditeljska kontrola ima za cilj usmjeravanje djetetovih ponašanja, misli i osjećaja bez uvažavanja djetetovih psiholoških potreba, a posebice potrebe za autonomijom, što negativno djeluje na intrinzičnu motivaciju (Skinner, Johnson i Snyder, 2005). Roditeljska kontrola potvrđena je kao negativni prediktor učeničkog postignuća u matematici (Aunola i Nurmi, 2004; Dinkelmann i Buff, 2016; Karbach, Gottschling, Spengler, Hegewald i Spinath, 2013; Silinskas, Kiuru, Aunola, Lerkkanen i Nurmi, 2015) te učeničkih uvjerenja o sposobnosti u matematici (Dinkelmann i Buff, 2016). 
Roditeljsko pružanje strukture odnosi se na usmjeravanje djeteta, jasno komuniciranje roditeljskih očekivanja i postavljanje granica (Grolnick i Pomerantz, 2009). U istraživanju koje su proveli Grolnick, Raftery-Helmer, Flamm, Marbell i Cardemil (2015) razina roditeljske strukture bila je pozitivno povezana s učeničkim uvjerenjima o sposobnosti u matematici $u$ višim razredima osnovne škole, dok su Dinkelmann i Buff (2016) pronašli pozitivan učinak na učenički interes za matematiku.

Naposljetku, roditeljska toplina se odražava u emocionalnoj responzivnosti roditelja te odnosu prema djetetu koji je empatičan, poštivajući i uvažava djetetove psihološke potrebe, a posebice potrebu za povezanošću (Skinner i sur., 2005). Razina topline u roditeljskim praksama u području matematike pokazala se kao značajan prediktor učeničkog postignuća, uvjerenja o sposobnosti i interesa za matematiku (Dinkelmann i Buff, 2016). Opisani nalazi sugeriraju da bi buduća istraživanja, osim frekvencije roditeljskih ponašanja, trebala ispitati i ove njihove kvalitativne dimenzije.

Nadalje, moguće je i da neka druga roditeljska ponašanja, koja nisu ispitana u ovom istraživanju, imaju medijacijsku ulogu u socijalizaciji učeničke motivacije za matematiku i tehničku kulturu. Prema Eccles (1993), roditelji svoja uvjerenja specifična za dijete mogu i komunicirati direktno tako da djetetu daju do znanja u kojem je području više, a u kojem manje kompetentno. Takve izravne mjere roditeljske komunikacije nisu uključene u ovo istraživanje, a mogle bi imati predviđenu medijacijsku ulogu. Hill i Tyson (2009) u svojoj meta-analizi roditeljska uvjerenja, vrijednosti, aspiracije i očekivanja svrstavaju u poseban oblik roditeljske uključenosti koju nazivaju akademskom socijalizacijom. Osim roditeljske komunikacije svojih uvjerenja, očekivanja i aspiracija, autori u ovaj oblik roditeljskih utjecaja uključuju i roditeljska ponašanja kao što su poticanje djetetovih obrazovnih i profesionalnih aspiracija, razgovor s djetetom o strategijama učenja te o budućim obrazovnim i profesionalnim planovima te povezivanje nastavnih sadržaja s budućim planovima i aspiracijama djeteta. Ova roditeljska ponašanja razvojno su primjerena razdoblju adolescencije (Hill i Tyson, 2009) pa bi također mogla imati pretpostavljenu medijacijsku ulogu u modelu. Neki prijašnji nalazi vezani uz ovaj oblik roditeljskih interakcija u STEM području prikazani su u potpoglavlju 5.3.3.

Kao što će dodatno biti riječi u potpoglavlju 5. 3. 2. i poglavlju 5. 4., u periodu rane adolescencije roditeljski utjecaji postaju sve suptilniji zbog velikih razvojnih promjena na kognitivnom i psihosocijalnom planu kod adolescenata (Hill i Tyson, 2009). Stoga je također moguće da roditelji u ovom razvojnom periodu svoja uvjerenja, očekivanja i aspiracije djeci prenose na načine koji su prisutni u svakodnevnoj komunikaciji s adolescentom, ali ih je teško zahvatiti eksplicitnim mjerama koje se odnose na konkretna roditeljska ponašanja. Na tragu tog 
razmatranja je i nalaz da se svakodnevne interakcije između roditelja i djece koje uključuju matematičke koncepte često događaju izvan okvira aktivnosti koje su eksplicitno vezane uz matematiku. S druge strane, mjere učestalosti roditeljskih ponašanja koja su eksplicitno vezana uz matematiku ne moraju nužno ukazivati koliko često takva ponašanja uistinu uključuju matematičke koncepte (Anderson, Anderson i Shapiro, 2004). Briley i suradnici (2014) također navode da se roditeljska obrazovna uvjerenja vezana uz dijete mogu odražavati u obrazovnoj socijalnoj klimi koja vlada u obitelji te da specifični oblici roditeljskog ponašanja možda ne mogu objasniti agregirani učinak te socijalne klime.

Zanimljivo je da je u našem istraživanju, kao i u istraživanju Simpkins i suradnica (2012), medijacijski efekt roditeljskih ponašanja pronađen samo u socijalizaciji učeničke subjektivne vrijednosti STEM školskih predmeta, ali ne i učeničke samoefikasnosti u ovim predmetima. Stoga je moguće da konkretna roditeljska ponašanja imaju veći socijalizacijski potencijal u oblikovanju učeničkog interesa za predmet i važnosti predmeta, dok su učenička uvjerenja o vlastitim sposobnostima pod drugom vrstom utjecaja. Primjerice, Chouinard i suradnici (2007) su ispitivali ulogu roditeljske podrške u matematici u predviđanju različitih vrsta učeničkih motivacijskih uvjerenja u matematici. Roditeljska podrška je imala pozitivan učinak na učeničku percepciju korisnosti matematike, no učenička samoefikasnost u matematici je bila pod utjecajem percipirane podrške od strane učitelja. I u drugim je istraživanjima potvrđeno da učiteljska podrška direktno predviđa učenička uvjerenja o sposobnostima i postignuće u matematici (Adams i Singh, 1998; Eccles, Wigfield, Midgley, Mac Iver i Feldlaufer, 1993). Ova istraživanja sugeriraju da ponašanja koja dolaze iz različitih socijalizacijskih izvora mogu imati različitu ulogu u oblikovanju učeničke samoefikasnosti i učeničke vrijednosti nastavnih predmeta u STEM području.

\section{3. Uloga roditeljskih ponašanja u objašnjenju učeničkih obrazovnih ishoda u matematici i tehničkoj kulturi}

$\mathrm{U}$ ispitanim modelima roditeljska ponašanja su postavljena kao izravni prediktori učeničkih motivacijskih uvjerenja iz matematike i tehničke kulture te učeničkog bavljenja izvanškolskim aktivnostima u matematičkom i tehničkom području. Kao što je objašnjeno u prethodnom poglavlju, roditeljska ponašanja su se pokazala kao slabi prediktori učeničke motivacije za matematiku i tehničku kulturu. S druge strane, pojedina roditeljska ponašanja su se pokazala kao značajni prediktori učeničkih matematičkih i tehničkih aktivnosti. Zanimljiv je nalaz da su u oba predmeta od učeničkih motivacijskih uvjerenja roditeljska ponašanja 
predviđala samo komponente subjektivne vrijednosti zadataka, ali ne i učeničku samoefikasnost, što je raspravljeno u prethodnom poglavlju. Stoga je moguće da izravna roditeljska ponašanja imaju utjecaj na učenički interes i važnost nastavnih predmeta STEM područja, dok na samoefikasnost djeluju druge, manje izravne vrste roditeljskih ponašanja koje nisu bile zahvaćene ovim istraživanjem.

Treba napomenuti da u SEM modelima koji su testirani u ovom istraživanju nije bila predviđena izravna poveznica između roditeljskih ponašanja i učeničkog postignuća, no budući da su brojna istraživanja na koja se u ovom dijelu rasprave referiramo ispitivala ovu vezu, provedene su dodatne analize u kojima su ovi putevi uključeni u testirane modele. Ove su analize potvrdile da kada se u obzir uzmu svi ostali prediktori u modelu, nijedan oblik roditeljskih ponašanja nije predviđao učeničko postignuće ni $\mathrm{u}$ jednom od modela iz matematike ni tehničke kulture. U narednim su potpoglavljima raspravljeni rezultati koji se odnose na zasebne oblike roditeljskih ponašanja ispitanih u ovom istraživanju.

\section{3. 1. Roditeljsko modeliranje}

Roditeljsko modeliranje u matematici nije imalo prediktivni efekt ni za jedan od učeničkih ishoda u matematici. S druge strane, roditeljsko modeliranje tehničkih aktivnosti imalo je određenu prediktivnu ulogu u modelima iz tehničke kulture. Naime, roditeljsko modeliranje predviđalo je viši interes učenika za tehničku kulturu i veću važnost tehničke kulture. Također, preko pozitivnog efekta na učeničke vrijednosti tehničke kulture, ovo ponašanje je pozitivno predviđalo i učeničko bavljenje tehničkim aktivnostima u slobodno vrijeme.

Dosadašnja istraživanja rijetko su se bavila roditeljskim modeliranjem aktivnosti specifičnih za STEM područje te su polučila nekonzistentne rezultate, no generalno se ovo ponašanje nije pokazalo kao snažan prediktor učeničkih obrazovnih ishoda u STEM području. Primjerice, u istraživanju Eccles i suradnika (1982) roditeljsko modeliranje matematičkih aktivnosti bilo je neznačajan prediktor učeničke samoefikasnosti, subjektivne vrijednosti zadatka, postignuća i planova o odabiru nastavnih kolegija iz matematike. Simpkins i suradnice (2005) ispitale su utjecaj roditeljskog modeliranja, poticanja djetetovih interesa, pribavljanja materijala te roditeljske uključenosti u području matematike, prirodoslovlja i računalnih aktivnosti. Među ispitanim ponašanjima, upravo je roditeljsko modeliranje bilo najslabije povezano s učeničkim sudjelovanjem u informalnim aktivnostima vezanim uz matematiku, prirodoslovlje i računala. S druge strane, u istraživanju kojeg su provele Jacobs i Bleeker (2004) 
majčino (ali ne i očevo) modeliranje aktivnosti u matematičkom i prirodoslovnom području predviđalo je učeničko bavljenje izvanškolskim aktivnostima u ovim STEM područjima dvije godine kasnije, ali ne i učenički interes za matematiku.

Istraživanje koje su proveli Eccles i suradnici (1982) pokazalo je da roditelji imaju snažniju ulogu u oblikovanju učeničkih motivacijskih uvjerenja u matematici kao "tumači djetetovih iskustava" nego kao modeli za ponašanje. Eccles (1993) navodi da roditeljsko modeliranje može imati veću ulogu kod mlađe djece, koja imaju veću potrebu za identifikacijom s roditeljima, nego kod adolescenata, što bi objasnilo i naše nalaze.

Moguće je da su mali prediktivni učinci roditeljskog modeliranja zabilježeni i zbog načina na koji je ovo ponašanje mjereno. Naime, podatak o tome koliko se često roditelj bavi određenom aktivnošću ne govori i koliko često dijete tu roditeljevu aktivnost uistinu opaža. $\mathrm{Na}$ tragu toga, također je moguće da su roditeljske tehničke aktivnosti u većoj mjeri istaknute i vidljive unutar svakodnevnih obiteljskih interakcija nego matematičke aktivnosti budući da tehničke aktivnosti uključuju korištenje alata, predmeta i strojeva. To bi objasnilo različitu prediktivnu snagu modeliranja u modelima iz matematike i tehničke kulture. Pored toga, čak i kad roditelji provode određene aktivnosti u vidokrugu djece, nekoliko se procesa mora odviti kako bi došlo do socijalnog učenja. Djeca najprije trebaju usmjeriti pažnju na ono što roditelj čini, zadržati informaciju o aktivnosti te biti motivirana za aktivnost i imati sposobnost da reproduciraju aktivnost (Bandura, 1997). Simpkins i suradnice (2005) napominju da su aktivnosti u STEM području kompleksne i tipično zahtijevaju izravnu instrukciju i adekvatnu razinu strukture kako bi djeca kroz njih stekla nova znanja i vještine koje su im potrebne da sama u tim aktivnostima sudjeluju te razviju interes za njih.

\section{3. 2. Roditeljska uključenost u školske obaveze}

Prije nego što raspravimo nalaze vezane uz roditeljsku uključenost u matematici i tehničkoj kulturi, valja napomenuti da termin "roditeljska uključenost" u literaturi o roditeljstvu označava meta-konstrukt koji objedinjuje različite vrste roditeljskih utjecaja. Pritom je prisutan nedostatak konsenzusa o njegovoj jasnoj definiciji i operacionalizaciji (Boonk, Gijselaers, Ritzen i Brand-Gruwel, 2018). Autori roditeljsku uključenost najčešće definiraju kao širok, multidimenzionalni konstrukt pod kojeg svrstavaju roditeljske varijable kao što su roditeljska uvjerenja, očekivanja i aspiracije, roditeljsko poticanje djetetovih interesa te roditeljska ponašanja u specifičnim područjima aktivnosti (npr. Boonk i sur., 2018; Fan i Chen, 2001; Singh i sur., 1995). Budući da smo u ovom radu slijedili model roditeljske socijalizacije dječjih 
obrazovnih ishoda Eccles i suradnika, u kojem su nabrojane varijable izdvojene kao zasebne vrste roditeljskih utjecaja, uključenost smo operacionalizirali mnogo uže, tako da se ona odnosila isključivo na roditeljsko sudjelovanje u učeničkim obavezama iz predmeta kod kuće ${ }^{35}$. Ovako definirana uključenost se u radovima najčešća pojavljuje kao jedan od indikatora šire domene roditeljske uključenosti „kod kuće“ (engl. home-based involvement) (npr. Epstein, 1987; Comer, 1995; Hoover-Dempsey i Sandler, 1997).

U našem istraživanju, ovako definirana roditeljska uključenost je bila blago negativno povezana s učeničkim interesom za matematiku. Pored toga, uključenost je bila negativno povezana s učeničkim bavljenjem matematičkim aktivnostima u slobodno vrijeme, a dodatne medijacijske analize su pokazale da se ova povezanost u cijelosti može pripisati upravo negativnom učinku roditeljske uključenosti na učenički interes za matematiku.

Velika većina ranijih istraživanja u kojima je uključenost operacionalizirana na sličan način kao u našem istraživanju, npr. kao roditeljsko pomaganje s domaćom zadaćom iz matematike, najčešće je bila usmjerena na učinak koji ovo ponašanje ima na učeničko postignuće, dok je učinak na motivacijska uvjerenja učenika mnogo rjeđe ispitivan (Silinskas i Kikas, 2019). U nekim istraživanjima roditeljsko pomaganje sa školskim obavezama iz matematike nije bilo povezano s učeničkim postignućem iz matematike (Wilder, 2013), dok je u drugima taj učinak bio negativan (Carmichael i MacDonald, 2016; Kung i Lee, 2016; Patall, Cooper i Robinson, 2008; Robinson, 2014). U longitudinalnom istraživanju koje su proveli Carmichael i MacDonald (2016) češće roditeljsko pomaganje sa domaćom zadaćom iz matematike bilo je povezano s nižim kasnijim postignućem učenika iz matematike čak i uz kontrolu ranijeg postignuća. Općenito se pokazalo da je roditeljsko pomaganje s domaćom zadaćom češće pozitivno povezano s postignućem u verbalnim predmetima nego u matematici (Robinson, 2014). Kao što je spomenuto na početku ovog poglavlja, dodatne analize u ovom radu su pokazale da roditeljska uključenost nije predviđala učeničko postignuće ni u matematici ni u tehničkoj kulturi, što je nalaz koji je na tragu opisanih prijašnjih istraživanja.

$\mathrm{U}$ jednom od rijetkih istraživanja u matematici u kojem je roditeljsko pomaganje $\mathrm{s}$ domaćom zadaćom iz matematike korelirano s učeničkom motivacijom u matematici (Silinskas i Kikas, 2019), učenička percepcija roditeljske kontrole u takvom ponašanju je negativno

\footnotetext{
${ }^{35} \mathrm{U}$ početnim SEM modelima, latentni konstrukt roditeljske uključenosti bio je definiran i indikatorom koji se odnosio na razgovor roditelja s djetetom o onome što uči na satovima iz matematike/tehničke kulture. No, kao što je prikazano u dijelu 'Rezultati', ovaj je indikator za oba predmeta pokazivao značajne križne saturacije s drugim roditeljskim faktorima u modelu te je zato isključen iz daljnjih analiza. Stoga se u konačnim modelima iz oba predmeta roditeljska uključenost odnosi isključivo na roditeljsko pomaganje djetetu oko obaveza iz predmeta (pomaganje oko domaće zadaće i pomaganje u pripremi za provjere znanja).
} 
predviđala učeničku samoefikasnost iz matematike, dok učenička percepcija podrške u roditeljskom pomaganju nije bila prediktor učeničke samoefikasnosti u matematici. U istraživanju koje su proveli Bhanot i Jovanovic (2005) roditeljski nadzor domaće zadaće iz matematike bio je povezan s nižim učeničkim uvjerenjima o sposobnosti u matematici, ali samo kod djevojčica.

Moguće je da neka kvalitativna odlika roditeljske uključenosti u djetetove obaveze iz matematike može objasniti negativan učinak uključenosti u našem i prošlim istraživanjima. Jedna od vrlo važnih kvalitativnih odlika roditeljske uključenosti jest razina roditeljske kontrole u odnosu na razinu podrške djetetovoj autonomiji koju takvo ponašanje uključuje (Silinskas i Kikas, 2019). Roditeljska uključenost koja podržava djetetovu potrebu za autonomijom kroz poticanje djetetovog nezavisnog rješavanja problema, donošenja izbora i sudjelovanja $u$ odlukama je pozitivno povezana s nizom obrazovnih ishoda kao što su postignuće, trud i interes za predmet, dok je uključenost koje je kontrolirajuća negativno povezana s ovim ishodima (Cooper, Lindsay i Nye, 2000; Gonzalez-DeHass, Willems i Doan Holbein, 2005). Prijašnja istraživanja ukazuju da karakteristike samog djeteta, kao što su nisko postignuće i niska motivacija za predmet, utječu na više roditeljsko uključivanje u djetetove školske obaveze (Pomerantz i Eaton, 2001; Silinskas i sur., 2015). Ako su motivirani primarno lošim prijašnjim postignućem svog djeteta, roditelji pri pomaganju u djetetovim školskim obavezama primjenjuju više kontrolirajućih strategija, a manje strategija koje potiču autonomiju (Silinskas i Kikas, 2019). Ovi bi nalazi mogli objasniti naše rezultate u matematici budući da su roditelji u našem uzorku u većoj mjeri uključivali u matematičke zadatke djeteta što su njihova uvjerenja vezana uz dijete u matematici bila negativnija.

Pored podrške djetetovoj autonomiji, Pomerantz i suradnici (2007) navode da roditeljska uključenost u djetetovu domaću zadaću može imati povoljne efekte na djetetovu motivaciju ako je orijentirana na proces, a ne na dijete, ako je karakterizira pozitivan roditeljski afekt i ako komunicira pozitivna uvjerenja roditelja o djetetovu potencijalu. Nastavno na posljednju od ove četiri dimenzije, naši rezultati su pokazali da roditeljska uključenost u matematici ne odražava pozitivna roditeljska uvjerenja o djetetovom potencijalu u matematici. Naime, kao što je rečeno, roditeljska uvjerenja o nižoj djetetovoj sposobnosti i interesu za matematiku su bila povezana s češćom roditeljskom uključenosti koja je pak predviđala niži učenički interes za matematiku te je ovaj medijacijski slijed bio značajan. Dakle, dobiveni rezultati u matematici se barem dijelom mogu objasniti nalazom da ovo roditeljsko ponašanje komunicira negativna roditeljska uvjerenja specifična za dijete u matematici. Buduća bi 
istraživanja trebala razmotriti i ostale nabrojane kvalitativne dimenzije roditeljske uključenosti $\mathrm{u}$ djetetove obaveze iz matematike u višim razredima osnovne škole.

Objašnjenja za dobivene nalaze možemo potražiti i u specifičnostima razvojnog perioda u kojemu se nalaze učenici u našem uzorku. Moguće je da u periodu adolescencije učenici roditeljsku uključenost u školske obaveze češće percipiraju kao kontrolirajuće ponašanje koje ne uvažava njihovu potrebu za autonomijom. Naime, jedna od osnovnih razvojnih zadaća adolescencije je upravo uspostavljanje autonomne slike o sebi (Zimmer-Gembeck i Collins, 2006). Ta razvojna specifičnost može smanjiti učinkovitost roditeljskog uključivanja u učeničke školske zadatke u adolescenciji (Seginer, 2006). Hill i Tyson (2009) su u svojoj metaanalizi obuhvatili samo istraživanja s učenicima u višim razredima osnovne škole te su pokazali da je roditeljsko pomaganje s domaćom zadaćom u ovom razvojnom periodu bilo negativno povezano s učeničkim postignućem. Kako bi se ovo objašnjenje moglo dodatno razmotriti, buduća bi istraživanja uz roditeljske izvještaje o uključenosti trebala uključiti i percepcije ovog roditeljskog ponašanja od strane adolescenata (Silinskas i Kikas, 2019). Također, prijašnja istraživanja pokazuju da u periodu viših razreda osnovne škole, sve više roditelja izvještava da se ne osjećaju kompetentnima pomoći svojoj djeci u školskim obavezama ili im pružiti aktivnosti koje bi pozitivno djelovale na djetetovo znanje ili školsko postignuće (Dauber i Epstein, 1993). Stoga je moguće da upravo u ovom periodu kvaliteta roditeljske uključenosti kod kuće bitno opada (Seginer, 2006).

Zanimljivo je da za razliku od matematike, u modelima iz tehničke kulture nije pronađena negativna povezanost roditeljske uključenosti ni s jednim od učeničkih obrazovnih ishoda u ovom predmetu. Naprotiv, utvrđena je mala pozitivna povezanost između roditeljske uključenosti u obaveze iz tehničke kulture i učeničke percepcije važnosti ovog predmeta. Također, preko veće važnosti tehničke kulture, roditeljska uključenost je imala i mali neizravni efekt na češće učeničko bavljenje tehničkim aktivnostima u slobodno vrijeme. Podatak da su roditelji u našem uzorku izvijestili da vrlo rijetko sudjeluju u djetetovim obavezama iz tehničke kulture može objasniti ovakav nalaz. Rijetka uključenost u djetetove obaveze iz tehničke kulture se pak vjerojatno može pripisati tome da većina učenika u našem uzorku postiže odličan ili barem vrlo dobar uspjeh iz tehničke kulture. Također, kutije s učeničkim radnim listovima i materijalima iz tehničke kulture najčešće ostaju u školi što onemogućuje roditeljima da pomažu djeci s praktičnim zadacima iz ovog nastavnog predmeta. Osim toga, moguće je i da kad se uključe u učeničke obaveze iz tehničke kulture, roditelji to čine na način koji je bitno kvalitativno drugačiji od pomaganja oko obaveza iz matematike. Primjerice, moguće je da takvo uključivanje ne komunicira niska roditeljska uvjerenja o potencijalu djeteta u predmetu 
ili nije kontrolirajuće budući da većina učenika u ovom predmetu ostvaruje visoke ocjene. U prilog ovakvom zaključku govori i nalaz, da za razliku od modela iz matematike, medijacijski učinak roditeljske uključenosti u objašnjavanju poveznice između negativnijih roditeljskih uvjerenja specifičnih za dijete u tehničkoj kulturi i nižeg učeničkog interesa za ovaj predmet, nije bio značajan.

Roditelji mogu s djecom sudjelovati i u aktivnostima u STEM području koje nisu vezane uz školske obaveze iz STEM nastavnih predmeta. Takve aktivnosti su, primjerice, zajednički rad na računalu, igranje matematičkih igara, posjeti tehničkim i prirodoslovnim muzejima. Budući da smo roditeljsku uključenost u ovom istraživanju operacionalizirali na način da se ona odnosila isključivo na roditeljsko sudjelovanje u učeničkim zadacima iz nastavnih predmeta, druge oblike roditeljske uključenosti raspravit ćemo u narednom poglavlju u kontekstu rasprave o ulozi roditeljskog poticanja interesa za STEM područje. Naime, pretpostavka je da takvim ponašanjima roditelji djeci mogu ne samo prenositi određena znanja i vještine, već i poticati njihov interes za STEM područje (Simpkins i sur., 2005).

\section{3. 3. Roditeljsko poticanje interesa}

Od svih roditeljskih ponašanja povezanih s matematikom, roditeljsko poticanje interesa za matematičke aktivnosti je u najvećoj mjeri predviđalo učeničko bavljenje matematičkim aktivnostima u slobodno vrijeme te učenički interes za matematiku. Roditeljsko poticanje u matematici je bilo povezano s češćim učeničkim bavljenjem aktivnostima u ovom području i neizravno - preko pozitivnog učinka na učenički interes za matematiku. U modelima iz tehničke kulture roditeljsko poticanje nije predviđalo motivacijska uvjerenja u predmetu, ali je kao i u modelima iz matematike, bilo najsnažniji roditeljski prediktor učeničkog bavljenja tehničkim aktivnostima u slobodno vrijeme.

Pretpostavka je da kroz poticanje interesa za školske i izvanškolske aktivnosti u STEM području roditelji djeci komuniciraju ne samo svoja uvjerenja specifična za dijete, već i osobnu percepciju vrijednosti STEM područja (Harackiewicz i sur., 2012). Prema Eccles (1993) roditeljsko poticanje određenih aktivnosti može pozitivno djelovati na učeničko bavljenje tim aktivnostima preko tri osnovna mehanizma. Najprije, roditeljsko poticanje može pozitivno utjecati na učeničku samoefikasnost u određenim aktivnostima te učeničku vrijednost tih aktivnosti što povećava vjerojatnost da će se učenici uistinu uključiti u aktivnosti u budućnosti. Ova pretpostavka je u našem istraživanju potvrđena u matematici gdje je roditeljsko poticanje predviđalo učeničko bavljenje matematičkim aktivnostima i neizravno preko višeg učeničkog 
interesa za matematiku. Kao drugo, roditeljsko poticanje djetetu signalizira da roditelj visoko vrednuje određenu aktivnost što može motivirati učeničku participaciju u toj aktivnosti budući da učenici na taj način internaliziraju roditeljeve vrijednosti te žele udovoljiti roditeljima kroz vlastito uključivanje u aktivnost. Naposljetku, ukoliko roditeljsko poticanje dovodi do pozitivnog afektivnog stanja kod učenika, kroz proces klasičnog uvjetovanja participacija u aktivnosti dobiva pozitivno afektivno značenje za učenika.

U našem smo istraživanju roditeljsko poticanje operacionalizirali na način da se ono odnosilo na poticanje interesa za aktivnosti koje nisu vezane uz nastavni predmet, već uz šire matematičko i tehničko područje, odnosno, uz informalne aktivnosti učenja u ovim područjima. U prijašnjim su se istraživanjima slična podržavajuća ponašanja roditelja odnosila na STEM školsko i izvanškolsko područje, kao i STEM zanimanja. Pritom su ova roditeljska ponašanja definirana kao roditeljsko poticanje (engl. encouragement), kao jedan od oblika ranije raspravljene roditeljske uključenosti (engl. involvement), dok u nekim radovima autori govore o roditeljskoj podršci (engl. support). Bez obzira na specifičnu definiciju i operacionalizaciju, ova ponašanja moguće je razmatrati kao podržavajuće i pozitivne interakcije između roditelja i djece, a koje pritom nisu orijentirane na roditeljsko sudjelovanje u djetetovim zadacima iz nastavnih predmeta.

Većina prošlih istraživanja je ukazala da su ovakve interakcije značajni prediktor različitih obrazovnih ishoda kod učenika. Primjerice, u istraživanju kojeg su proveli Turner i suradnici (2004) i majčina i očeva podrška djetetovog profiliranja prema karijerama vezanim uz matematiku i prirodoslovlje pozitivno je predviđala samoefikasnost $\mathrm{u}$ matematici kod adolescenata, dok je majčina podrška također pozitivno predviđala učeničko očekivanje uspjeha u matematici. George i Kaplan (1998) su pokazali da frekvencija razgovora roditelja s djetetom o odabiru nastavnih predmeta i karijera u prirodoslovnom području pozitivno objašnjava učenički interes za prirodne predmete i učeničko bavljenje izvanškolskim aktivnostima u matematičkom i prirodoslovnom području u osmom razredu. Chouinard i suradnici (2007) su pokazali da je roditeljska podrška vezana uz matematiku kao predmet pozitivno predviđala percepciju korisnosti matematike kod učenika u dobi od oko 15 godina. U istraživanju Simpkins i suradnica $(2015 \mathrm{c})$ roditeljsko zajedničko sudjelovanje s adolescentima u aktivnostima vezanim uz prirodne znanosti, kao što je gledanje znanstvenih emisija i razgovor o važnosti prirodnih znanosti, pozitivno je predviđalo učeničku samoefikasnosti i subjektivnu vrijednost biologije, kemije i fizike kao nastavnih predmeta.

Možemo zaključiti da naši nalazi, kao i nalazi prijašnjih istraživanja, ukazuju da ovakav oblik roditeljskih interakcije u STEM području ima pozitivniji socijalizacijski potencijal nego 
ranije raspravljena roditeljska uključenost $u$ djetetove obaveze iz nastavnih predmeta u STEM području. Zanimljivo je da je u našem istraživanju roditeljsko poticanje imalo posebice snažan učinak u predviđanju učeničkog bavljenje aktivnostima u tehničkom području. Moguće je da je to zato što su, za razliku od matematike, učenici manje izloženi tehničkim aktivnostima unutar redovne nastave pa je uloga roditeljskog poticanja u toj domeni veća nego u matematici.

\section{3. 4. Roditeljsko pribavljanje obrazovnih materijala iz STEM područja}

U ovom se istraživanju roditeljsko pribavljanje obrazovnih materijala iz STEM područja pokazalo kao neznačajan prediktor učeničkih obrazovnih ishoda u matematici i tehničkoj kulturi. Naime, ovo roditeljsko ponašanje nije bilo povezano ni s učeničkom motivacijom za matematiku i tehničku kulturu niti s učeničkim bavljenjem aktivnostima u ovim područjima u slobodno vrijeme. Kao što je prethodno već spomenuto, izuzetak je vrlo niska negativna povezanost koja je pronađena s učeničkom samoefikasnosti u tehničkoj kulturi, a koja na bivarijatnoj razini nije bila značajna.

U istraživanju kojeg su proveli Sha, Schunn, Bathgate i Ben-Eliyahu (2016) roditeljsko pribavljanje različitih materijala povezanih s prirodoslovljem, kao i općih obrazovnih resursa također nije bilo povezano s učeničkim motivacijskim uvjerenjima u prirodoslovlju. Na tragu naših nalaza, u istraživanju kojeg su provele Simpkins i suradnice (2005) roditeljsko pribavljanje knjiga, časopisa i igračaka u području matematike i prirodoslovlja bilo je nepovezano $\mathrm{s}$ učeničkim izvještajima o sudjelovanju u matematičkim izvanškolskim aktivnostima te vrlo nisko povezano $\mathrm{s}$ izvještajima o sudjelovanju $\mathrm{u}$ izvanškolskim aktivnostima vezanim uz prirodoslovlje. Međutim, zanimljivo je da je u istom istraživanju utvrđena umjerena pozitivna korelacija između učeničkih izvještaja o frekvenciji bavljenja računalnim izvanškolskim aktivnostima i roditeljskog pribavljanja materijala kao što su računalni programi, knjige, časopisi i sl. Stoga je moguće da je pribavljanje STEM materijala više povezano s ishodima u onim STEM područjima koja nisu zastupljena u redovnoj nastavi. Primjerice, iako su u većini osnovnih škola računala uključena u nastavu, učenici u školi ne provode toliko vremena na računalima koliko provode učeći sadržaje iz obaveznih predmeta STEM područja. Stoga roditeljski utjecaji mogu biti važniji i izraženiji u STEM područjima koja nisu zastupljena u redovnoj nastavi (Simpkins i sur., 2005).

S druge strane, za razliku od naših nalaza, Jacobs i Bleeker (2004) su utvrdile da je roditeljsko pribavljanje materijala i aktivnosti vezanih uz matematiku i prirodoslovlje kada su djeca polazila drugi razred osnovne škole pozitivno predviđalo učeničko bavljenje 
izvanškolskim aktivnostima u ovim područjima u četvrtom razredu te učenički interes za matematiku u osmom razredu osnovne škole. Međutim, autorice nisu koristile čistu mjeru roditeljskog pribavljanja materijala, već su uz STEM materijale mjerile i koliko često roditelji djetetu omogućuju različite aktivnosti u STEM području, kao što su posjeti muzejima.

Naši se rezultati mogu objasniti i time da roditeljsko pribavljanje obrazovnih materijala ne podrazumijeva da djeca te materijale uistinu i koriste ili da ih koriste na način koji bi promovirao njihovu motivaciju za STEM obrazovnim područjem. U razmatranju dobivenih nalaza, treba u obzir uzeti i činjenicu da su roditelji u našem uzorku izvijestili da njihova djeca imaju relativno mali broj ispitivanih materijala na raspolaganju kod kuće. Reducirana varijanca u ovoj varijabli može biti u podlozi dobivenih rezultata. Naposljetku, moguće je da roditeljsko pribavljanje obrazovnih materijala iz STEM područja stvara obrazovne razlike u STEM području prvenstveno kod mlađe djece, prije nego što se ona susretnu s obrazovnim materijalima kroz svoje redovno školovanje. Istraživanja u matematici, primjerice, pokazuju da je kvaliteta uvjeta za učenje kod kuće povezana s razlikama u ranom matematičkom znanju već kod djece u dobi od tri godine (Anders i sur., 2012).

\section{4. Usporedba relativnog doprinosa roditeljskih varijabli u objašnjavanju učeničkih obrazovnih ishoda u matematici i tehničkoj kulturi}

Jedna od prednosti ovog istraživanja je što smo unutar istog modela uključili različite oblike roditeljskih utjecaja što nam je omogućilo usporedbu njihove uloge u objašnjavanju učeničkih obrazovnih ishoda u matematici i tehničkoj kulturi. Pritom je bilo očekivano da će roditeljska uvjerenja imati najsnažniji i najkonzistentniji prediktivni učinak. Budući da su prediktivni efekti obrazovanja roditelja u strukturalnim modelima bili slabi ili neznačajni, u ovom ćemo poglavlju usporediti ulogu roditeljskih uvjerenja i ponašanja.

Dobiveni nalazi upućuju na dvije stvari. Najprije, roditeljska uvjerenja i ponašanja ističu se kao prediktori različitih obrazovnih ishoda u matematici i tehničkoj kulturi. Roditeljska uvjerenja su prediktori učeničke motivacije i postignuća, a roditeljska ponašanja su prediktori izvanškolskih aktivnosti u matematičkom i tehničkom području. Sveobuhvatno gledano, roditeljska uvjerenja su potvrđena kao snažniji i konzistentniji prediktori učeničkih obrazovnih ishoda budući da su sve izravne veze između roditeljskih uvjerenja i učeničkih ishoda potvrđene, a pritom je većina učinaka bila umjerena do snažna. Jedini izuzetak je odsustvo poveznice s postignućem iz tehničke kulture što se može pripisati vrlo niskom varijabilitetu učeničkih ocjena iz ovog predmeta. S druge strane, samo neka od roditeljskih ponašanja su bila 
značajni prediktori učeničkih izvanškolskih aktivnosti u matematičkom i tehničkom području, a pritom je većina efekata bila mala.

U prošlim preglednim istraživanjima i meta-analizama doprinos roditeljskih ponašanja i uvjerenja je uspoređivan prvenstveno u predviđanju školskog postignuća učenika (Boonk i sur., 2018; Fan i Chen, 2001; Hill i Tyson, 2009; Wilder, 2013). I u tim je istraživanjima konzistentno utvrđeno da među različitim oblicima roditeljskih utjecaja kod kuće i u školi upravo roditeljska uvjerenja, očekivanja i aspiracije imaju najveći doprinos u predviđanju učeničkog postignuća u matematici, ali i u nastavnim predmetima izvan STEM obrazovnog područja.

Ovi i naši nalazi mogu se objasniti promjenama koje se događaju u odnosu između roditelja i djece u periodu adolescencije. Najprije, kako djeca odrastaju i napreduju kroz svoje školovanje, roditelji sve manje sudjeluju u njihovom obrazovanju kroz specifična ponašanja (Grolnick, Ryan i Deci, 1991; Muller, 1998; Paulson i Sputa, 1996). Pored toga, budući da ranu adolescenciju obilježava značajan kognitivni napredak te izražena potreba za uspostavljanjem autonomije i nezavisne slike o sebi, hijerarhija uloga između roditelja i djeteta se bitno mijenja, a komunikacija u sve većoj mjeri postaje dvosmjerna (Collins i Laursen, 2004). U adolescenciji se, stoga, roditeljski utjecaji u obrazovanju sve više ostvaruju upravo kroz neizravne utjecaje kao što su roditeljska uvjerenja o sposobnostima, vještinama i potencijalu djece (Hill i Tyson, 2009). Također, razdoblja tranzicija kod pojedinaca povećavaju potrebu za vanjskim informacijama o njihovim sposobnostima kako bi se lakše prilagodili novom kontekstu (Ruble, 1994). Stoga bi razdoblje rane adolescencije trebalo biti pod većim utjecajem povratnih informacija nego razvojna razdoblja koja ne odlikuju značajne tranzicije (Bronfenbrenner, 1979). Ovaj bi nalaz mogao objasniti važnost roditeljskih uvjerenja i kod učenika u našem uzorku budući da su oni nedavno prošli kroz tranziciju u više razrede osnovne škole te ih uskoro očekuje tranzicija u srednju školu.

Naši su nalazi također u skladu s postavkama teorije očekivanja i vrijednosti prema kojima su roditeljska uvjerenja specifična za dijete primarne socijalizacijske odrednice učeničke percepcije vlastitih sposobnosti te učeničkog postignuća (Eccles, 2007; Fredricks i Eccles, 2002; Frome i Eccles, 1998).

U skladu s postavljenom hipotezom, roditeljska ponašanja uključenosti i poticanje interesa imala su veću ulogu u predviđanju učeničkih obrazovnih ishoda u matematici nego roditeljsko pribavljanje STEM materijala i roditeljsko modeliranje. Ovi se nalazi mogu objasniti time da roditeljska uključenost i poticanje interesa predstavljaju oblike direktne interakcije između djeteta i roditelja, dok se pribavljanje materijala i modeliranje odnose na 
obilježja djetetovog okružja (Simpkins i sur., 2005). Ranije raspravljena roditeljska toplina, podrška djetetovoj autonomiji te adekvatna struktura smatraju se ključnim preduvjetima za procese internalizacije roditeljskih uvjerenja i vrijednosti kod djece (Grolnick i Ryan, 1989). Za očekivati je da ove kvalitativne odlike roditeljstva više dolaze do izražaja u izravnim interakcijama roditelja i djeteta nego u načinima na koje roditelji oblikuju djetetovo okruženje. U tehničkoj kulturi ova hipoteza nije u cijelosti potvrđena, budući da su roditeljska uključenost i pribavljanje materijala imali podjednako slab doprinos u objašnjavanju učeničkih obrazovnih ishoda, dok su roditeljsko modeliranje i poticanje interesa imali snažniji doprinos u objašnjavanju učeničkih obrazovnih ishoda. Ove razlike u odnosu na modele iz matematike se vjerojatno mogu pripisati razlikama u roditeljskom modeliranju i uključenosti u tehničkom području koje su opisane u prethodnim poglavljima.

\section{5. Moderatorski učinak roda učenika}

Hipoteza o strukturalnoj invarijantnosti testiranih modela roditeljske socijalizacije dječjih obrazovnih ishoda s obzirom na rod učenika većim je dijelom potvrđena. U tehničkoj kulturi su modeli s učeničkom samoefikasnosti i interesom za predmet bili u cijelosti invarijantni za učenike i učenice, dok za model s važnosti ovu hipotezu nismo mogli provjeriti budući da nije pronađena metrijska invarijantnost faktora važnosti tehničke kulture za učenike i učenice. U matematici je strukturalna invarijantnost modela većim dijelom potvrđena izuzev nekoliko puteva u modelu sa samoefikasnosti koji će biti ukratko raspravljeni u ovom poglavlju.

U modelu sa samoefikasnosti u matematici roditeljska uključenost u učeničke obaveze iz matematike negativno je predviđala bavljenje matematičkim aktivnostima u slobodno vrijeme, ali samo kod dječaka. Međutim, rezultati dobiveni u modelu s učeničkim interesom za matematiku, koji su raspravljeni u potpoglavlju 5. 3. 2., pokazali su da se negativni prediktivni učinak roditeljske uključenosti na učeničko bavljenje matematičkim aktivnostima u cijelosti ostvaruje preko negativnog učinka koje ovo roditeljsko ponašanje ima na učenički interes za matematiku. Budući da je model s interesom bio strukturalno invarijantan za oba roda učenika, možemo zaključiti da je mehanizam djelovanja roditeljske uključenosti na učeničko bavljenje matematičkim aktivnostima jednak u slučaju djevojčica i dječaka.

Također se pokazalo da je čestina bavljenja matematičkim aktivnostima u slobodno vrijeme u modelu sa samoefikasnosti negativno predviđala postignuće iz matematike kod učenica, ali ne i kod učenika. Budući da su u fokusu ovog istraživanja roditeljske odrednice učeničkih obrazovnih ishoda, ovaj nalaz nije relevantan za zaključivanje o rodnoj 
invarijantnosti socijalizacijskih utjecaja u matematici. Međutim, ukratko ćemo komentirati njegovo značenje. Zanimljivo je da u modelima s interesom i važnosti matematike bavljenje matematičkim aktivnostima uopće nije predviđalo postignuće učenika i taj je nalaz vrijedio za oba roda. Očito je, dakle, da kada se iz čestine bavljenja matematičkim aktivnostima parcijalizira dio varijance koji je povezan s učeničkom samoefikasnosti u matematici, bavljenje aktivnostima blago negativno predviđa postignuće iz matematike $\mathrm{i}$ to samo kod učenica. Moguće je da dio varijance u bavljenju matematičkim aktivnostima koji je nepovezan $s$ učeničkom samoefikasnosti u matematici kao nastavnom predmetu odražava bavljenje matematičkim aktivnostima koje nema za cilj razvijanje matematičke kompetencije već je motivirano drugim faktorima kao što je primjerice želja za zabavom ili druženjem s vršnjacima, što bi objasnilo negativan odnos s kasnijim postignućem iz matematike. Ovakve su aktivnosti možda češće kod djevojčica, dok je kod dječaka bavljenje izvanškolskim matematičkim aktivnostima možda više povezano s njihovom samoefikasnosti u matematici kao nastavnom predmetu.

Naposljetku, pokazalo se da kad su u obzir uzeti svi drugi proksimalni roditeljski utjecaji u matematici, obrazovanje roditelja zadržava mali izravni učinak u predviđanju postignuća iz matematike kod učenica, ali ne i kod učenika. Moguće je da u slučaju ženske djece obrazovaniji roditelji češće provode određena ponašanja ili zastupaju određena uvjerenja ili vrijednosti koje nismo ispitali u ovom istraživanju, a koja imaju nezavisan doprinos u objašnjavanju postignuća učenica iz matematike, pored svih ostalih roditeljskih i učeničkih varijabli koje su uključene u model.

Rodna invarijantnost socijalizacijskih procesa pretpostavljena je modelom roditeljske socijalizacije dječjih obrazovnih ishoda, a i prethodna su istraživanja pokazala da su roditeljski socijalizacijski učinci u STEM području vrlo slični za mušku i žensku djecu (Aunola i sur., 2003; Chouinard i sur., 2007; Eccles i sur., 1982; Gladstone i sur., 2018; Pesu i sur., 2016; Simpkins i sur., 2005; Simpkins i sur., 2012; Simpkins i sur., 2015c). Simpkins i suradnice (2012) navode da dokazi o rodnoj invarijantnosti socijalizacijskih procesa sugeriraju da se intervencijski programi koji uključuju roditelje mogu usmjeriti na iste roditeljske utjecaje, bez obzira na rod djeteta.

\section{6. Moderatorski učinak obrazovanja roditelja}

U ovom smo istraživanju postavili dvije hipoteze vezane uz moderatorski učinak obrazovanja roditelja. Prema prvoj hipotezi je bilo očekivano da će kod roditelja višeg 
obrazovanja prethodno postignuće njihove djece u matematici i tehničkoj kulturi biti snažnije povezano s roditeljskim uvjerenjima specifičnim za dijete u ovim predmetima. Prema drugoj hipotezi, kod roditelja višeg obrazovanja njihova uvjerenja specifična za dijete u matematici i tehničkoj kulturi su trebala biti snažnije povezana s njihovim ponašanjima u ovim područjima. U matematici su ove hipoteze djelomično potvrđene, dok u tehničkoj kulturi ove hipoteze nismo potvrdili.

Nastavno na prvu hipotezu, neka prošla istraživanja su utvrdila da je poveznica između stvarnog postignuća učenika i roditeljskih uvjerenja slabija kod roditelja nižeg SES-a. Primjerice, u istraživanju kojeg su proveli Alexander i suradnici (1994) roditeljska očekivanja djetetovog uspjeha u matematici u četvrtom razredu osnovne škole bila su snažnije povezana s učeničkim ocjenama iz matematike ukoliko su roditelji bili višeg SES-a. Na uzorku roditelja djece koja su polazila prvi razred osnovne škole Balboni i Pedrabissi (1998) su utvrdili da su roditeljska opća obrazovna očekivanja bila više u skladu s učiteljskim procjenama djece ukoliko su roditelji bili višeg SES-a.

U našem istraživanju prva hipoteza nije potvrđena ni u jednom od predmeta. Drugim riječima, roditeljska uvjerenja su u jednakoj mjeri bila pozitivno povezana sa stvarnim prethodnim postignućem učenika u predmetu, bez obzira na obrazovanje roditelja. U matematici se ovaj nalaz možda može pripisati dobi učenika. Naime, kao što je već dijelom raspravljeno u potpoglavlju 5. 1. 1., budući da smo u istraživanje uključili učenike viših razreda osnovne škole za očekivati je da do tog perioda školovanja roditelji već imaju dobro razvijenu sliku o sposobnostima svoje djece u matematici, bez obzira na svoje obrazovanje. Naime, matematika je predmet koji se poučava od početka školovanja, u velikoj satnici, pa roditelji često primaju povratne informacije iz škole koje imaju korektivnu ulogu u oblikovanju roditeljskih uvjerenja (Eccles, 1993; Entwisle i Hayduk, 1978). Stoga je moguće da je moderatorski efekt obrazovanja roditelja u matematici važniji pri početku školovanja, kada roditelji još nemaju toliko veliku količinu objektivnih informacija o svojoj djeci. Roditeljska ponašanja kao što su komunikacija sa školom i nastavnicima u tom bi periodu školovanja mogla imati važniju ulogu u formiranju točnih roditeljskih uvjerenja o djetetovim sposobnostima. Istraživanja pokazuju da roditelji višeg SES-a češće provode takve aktivnosti (Green, Walker, Hoover-Dempsey i Sandler, 2007; Grolnick i sur., 1997; Grolnick i Slowiaczek, 1994; Pomerantz i sur., 2007).

S druge strane, tehnička kultura je predmet koji se poučava tek od petog razreda osnovne škole, u bitno manjoj satnici od matematike, pa slično objašnjenje za izostanak moderatorskog efekta obrazovanja roditelja nije toliko primjenjivo. Nalaz u tehničkoj kulturi se možda može 
objasniti time da je korelacija između prošlog postignuća i roditeljskih uvjerenja u tehničkoj kulturi bila značajno niža nego korelacija između ovih varijabli u matematici, što je posljedica reducirane varijance u učeničkim ocjenama iz tehničke kulture. Naime, poznato je da je moderacijske efekte teže detektirati što je korelacija između prediktorske i kriterijske varijable niža (Rogers, 2002).

Što se tiče druge istraživačke hipoteze vezane uz obrazovanje roditelja kao moderator, ona je u matematici većim dijelom potvrđena. Negativnija roditeljska uvjerenja bila su povezana s češćom uključenosti roditelja u obje skupine roditeljskog obrazovanja, no, u skladu s hipotezom, ta je povezanost bila snažnija kod roditelja višeg obrazovanja. Pored toga, roditeljska uvjerenja su bila pozitivno povezana s roditeljskim poticanjem djetetovih interesa za matematiku samo u skupini više obrazovanih roditelja, dok u skupini niže obrazovanih roditelja ovaj regresijski put nije bio značajan. Obrazovanje roditelja jedino nije moderiralo pozitivan odnos između uvjerenja roditelja i pribavljanja STEM materijala za dijete.

Nedostatak obrazovnih, financijskih i vremenskih resursa, kao i veći broj vanjskih stresora može otežavati roditeljima nižeg SES-a da svoje socijalizacijske ciljeve, uvjerenja i vrijednosti prevode u adekvatne obrazovne prakse (Eccles, 1993; Spera 2005; Spera 2006). Osim ograničenih resursa, naši se nalazi mogu objasniti i razlikama u određenim osobnim uvjerenjima kod roditelja višeg i nižeg SES-a. Primjerice, roditelji koji su više obrazovani imaju snažnija uvjerenja o svojoj aktivnoj ulozi u obrazovanju svoje djece te su sigurniji u svoje kompetencije da pridonesu djetetovom akademskom postignuću (DeBaryshe, 1995; Marjoribanks, 2002; Schneider i Coleman, 1993; Whitaker i Hoover-Dempsey, 2013; Yamamoto, Holloway i Suzuki, 2016). Zbog ovih razloga roditelji višeg SES-a mogu uspješnije prilagoditi svoje prakse percepciji djetetovog interesa i sposobnosti u matematici. Nalaz da obrazovanje roditelja nije moderiralo jedino odnos između roditeljskih uvjerenja i roditeljskog pribavljanja STEM materijala sugerira da se pronađeni moderatorski efekti obrazovanja roditelja mogu u većoj mjeri pripisati upravo razlikama u obrazovnim resursima više i manje obrazovanih roditelja, a u manjoj mjeri razlikama u financijskim resursima.

Hipoteza o moderatorskom efektu obrazovanja roditelja u objašnjavanju poveznice između roditeljskih uvjerenja i ponašanja nije potvrđena ni za jedno roditeljsko ponašanje u modelima iz tehničke kulture. Pritom nije bilo moguće ispitati moderatorski efekt obrazovanja roditelja u poveznici između roditeljskih uvjerenja i uključenosti budući da ovaj odnos nije bio značajan. Što se tiče izostanka moderatorskog efekta roditeljskog obrazovanja u poveznici između roditeljskih uvjerenja i roditeljskog poticanja djetetovih interesa za tehničke aktivnosti, moguće je da za razliku od matematičkog područja, u tehničkom području ovo roditeljsko 
ponašanje u manjoj mjeri iziskuje obrazovne resurse roditelja. Naime, u odnosu na matematiku, aktivnosti u tehničkom području imaju mnogo više izraženu praktičnu komponentu, a većina učenika u ovom predmetu postiže visok uspjeh. Stoga je moguće da roditelji nižeg obrazovanja ne percipiraju da trebaju imati izražene obrazovne resurse kako bi pružili adekvatnu podršku svom djetetu u ovom području.

\section{7. Ograničenja istraživanja i preporuke za buduća istraživanja}

U ovom ćemo poglavlju raspraviti neka, prvenstveno metodološka, ograničenja provedenog istraživanja te izvesti preporuke za buduća istraživanja socijalizacijskih utjecaja u STEM obrazovnom području. Najprije, u ovom smo istraživanju ispitali različite oblike roditeljskih utjecaja, no brojni potencijalno važni izvori tih utjecaja su izostavljeni. Među distalnim roditeljskim karakteristikama u obzir je uzeto samo obrazovanje roditelja iako istraživanja sugeriraju da i druge distalne karakteristike mogu utjecati na učeničke ishode $u$ STEM području. Primjerice, prijašnja su istraživanja pokazala da zanimanje roditelja koje je u STEM području može pozitivno djelovati na učenički interes za nastavne predmete STEM područja (Guo, Marsh, Parker, Dicke i Van Zanden, 2019), interes i aspiracije za STEM karijere (Archer i sur., 2012; Archer, Dewitt i Willis, 2014; Holmes, Gore, Smith i Lloyd, 2018) te vjerojatnost odabira fakulteta u STEM području (Moakler i Kim, 2014). Nadalje, za sveobuhvatan uvid u poveznicu između SES-a i učeničkih obrazovnih ishoda u STEM području, osim obrazovanja roditelja, u obzir bi trebalo uzeti i roditeljski financijski status. Naime, istraživanja provedena u matematici pokazuju da ova dva SES indikatora imaju nezavisnu ulogu u objašnjavanju obrazovnih ishoda kao što je postignuće iz matematike (Cheadle, 2008; Bachman, Votruba-Drzal, El Nokali, Castle i Heatly, 2015).

Model roditeljske socijalizacije dječjih obrazovnih ishoda osim roditeljskih uvjerenja specifičnih za dijete, ističe i važnost općih roditeljskih uvjerenja (Eccles i sur., 1983) koja također nisu uključena u modele testirane u ovom istraživanju. Prijašnja su istraživanja pokazala da roditeljski rodni stereotipi u STEM području (Jacobs, 1991), roditeljske osobne vrijednosti vezane uz STEM područje (Acosta i Hsu, 2014; Gniewosz i Noack, 2012; Hsu i Acosta, 2011; Lazarides, Rubach i Ittel, 2017) te roditeljska uvjerenja o općim akademskim kompetencijama djeteta (Aunola i sur., 2003) mogu biti važni prediktori različitih učeničkih obrazovnih ishoda u nastavnim predmetima STEM područja. Također, prema modelu roditeljske socijalizacije dječjih obrazovnih ishoda se pretpostavlja da opća uvjerenja roditelja 
mogu utjecati na specifična roditeljska uvjerenja i prakse u određenom području aktivnosti (Eccles, 1993).

Korištenim mjerama također nismo zahvatili kvalitetu roditeljskih ponašanja. Kako je objašnjeno na više mjesta u ovoj raspravi, neuključivanje indikatora kvalitete ponašanja može objasniti izostanak pojedinih pretpostavljenih odnosa u modelu. Pored toga, prema modelu roditeljske socijalizacije dječjih obrazovnih ishoda, kvaliteta roditeljskih interakcija s djetetom može imati i ulogu moderatorske varijable. Naime, učinkovitost socijalizacije u velikoj mjeri ovisi o afektivnoj i motivacijskoj klimi koju roditelji stvaraju u interakcijama s djetetom (Eccles, 2007). U obiteljima s pozitivnom emocionalnom klimom je veća vjerojatnost da će dijete internalizirati roditeljska uvjerenja i vrijednosti te preuzeti roditeljska ponašanja (Ecces, 1993).

Jedno od ograničenja istraživanja je i što su u ispitivanju roditeljskih utjecaja korišteni samo roditeljski izvještaji kao izvor podataka. Istraživači u području roditeljstva sugeriraju da bi se $\mathrm{u}$ istraživanjima roditeljskih utjecaja trebalo nastojati koristiti izvještaje dobivene od roditelja, ali i mjere dječjih percepcija roditeljskih utjecaja (Silk, Morris, Kanaya i Steinberi 2003; Su, Doerr, Johnson, Shi i Spinath, 2015). Ovakav je pristup primjeren i iz pozicije teorijskog okvira preuzetog u ovom istraživanju. Naime, u modelu roditeljske socijalizacije dječjih obrazovnih ishoda postoji distinkcija između roditeljske percepcije vlastitih uvjerenja i ponašanja i dječjih percepcija ovih utjecaja (Eccles, 2015; Wigfield i Eccles, 2000). Pritom bi, prema modelu, dječje percepcije roditelja trebale djelovati kao medijatori u odnosu između roditeljskih izvještaja o njihovim socijalizacijskim utjecajima i dječje motivacije za postignućem.

U ovom smo istraživanju ispitali samo jednog od roditelja učenika te su majke činile većinu roditeljskog uzorka. Stoga nismo mogli ispitati razlikuju li se roditeljski utjecaji s obzirom na rod roditelja te s obzirom na rodne dijade roditelj - dijete. Međutim, prošla istraživanja sugeriraju da je varijablu roda roditelja smisleno uključiti u modele roditeljske socijalizacije dječjih obrazovnih ishoda u STEM obrazovnom području. Primjerice, u istraživanju Turnera i suradnika (2004) samo je majčina, ali ne i očeva podrška predviđala učenička očekivanja uspjeha u matematici. U drugom su istraživanju samo majčina, ali ne očeva ponašanja u prirodoslovlju predviđala kasniju motivaciju za prirodoslovlje kod učenika (Bhanot i Jovanovic, 2009). U istraživanju međugeneracijskog prijenosa opće vrijednosti matematike pronađeno je da će djevojčice prije internalizirati majčinu vrijednost matematike, a dječaci očevu (Gniewosz i Noack 2012). Nedavno istraživanje koje su proveli Gladstone i sur. (2018) pokazalo je da su majčine i očeve percepcije djetetovih sposobnosti u matematici bile u 
interakciji u previđanju učeničkih obrazovnih ishoda u ovom predmetu. Razmatranje uloge roda roditelja važno je i zbog toga što su očevi uvelike zanemareni u istraživanjima u području STEM obrazovanja (Bhanot i Jovanovic, 2009).

Nadalje, jedna od važnih pretpostavki modela roditeljske socijalizacije dječjih obrazovnih ishoda Eccles i suradnika je recipročna dinamika utjecaja između roditelja i djece. Iako se teorijski pretpostavlja da je smjer utjecaja snažniji od roditelji prema djeci, a neki empirijski nalazi to i potvrđuju (Häfner i sur., 2016; Lazarides i sur., 2017; Simpkins i sur., 2015b), također se očekuje i da su roditeljska uvjerenja i ponašanja često uvjetovana prethodnim postignućem, ponašanjima i preferencijama djeteta za različite aktivnosti (Simpkins i sur., 2012). Primjerice, istraživanje koje su proveli Briley i suradnici (2014) pratilo je djecu i njihove roditelje od perioda kada su djeca imala četiri godine do petog razreda osnovne škole. Istraživanje je pokazalo da su učenički obrazovni ishodi u matematici bili pod utjecajem roditeljskih obrazovnih očekivanja, ali i da su ta roditeljska očekivanja pod značajnim utjecajem djetetovih individualnih karakteristika kao što su djetetove kognitivne sposobnosti, školsko postignuće u matematici te opće akademsko ponašanje djeteta. Pritom su ove dvosmjerne veze ustanovljene još prije djetetovog polaska u školu. Zbog ovakvih nalaza brojni teoretičari socijalizacije govore o transakcijskim procesima između roditelja i djece, a ne tek jednostavnoj transmisiji roditeljskih utjecaja prema djetetu (Bronfenbrenner i Ceci, 1994; Collins, Maccoby, Steinberg, Hetherington i Bornstein, 2000; Sameroff, 2009; Tucker-Drob, Briley i Harden, 2013). U našem istraživanju nije bilo moguće ispitati ovakve dinamične procese budući da smo roditeljske varijable odmjerili samo u jednoj vremenskoj točki, kao i pojedine vrste učeničkih varijabli. Kako bi se u STEM obrazovnom području mogli utvrditi smjer i snaga recipročnih utjecaja između roditelja i djece potrebno je koristiti longitudinalne križne nacrte istraživanja (engl. cross-lagged). U ovim se nacrtima iste roditeljske i učeničke varijable mjere u više vremenskih točaka što omogućuje usporedbu snage različitih smjerova utjecaja između roditeljskih i učeničkih varijabli. Ovakvi su istraživački nacrti posebice nužni za potpuno razumijevanje roditeljskih utjecaja u periodu adolescencije kada se pretpostavlja da recipročna dinamika između roditelja i djeteta postaje sve izraženija zbog djetetovog sazrijevanja i razvoja autonomije (Simpkins i sur., 2012).

Korišteni istraživački nacrt također nam ne omogućava donošenje kauzalnih zaključaka o roditeljskoj ulozi u učeničkim obrazovnim ishodima u matematici i tehničkoj kulturi. Pored toga, u ovom smo istraživanju ispitivali niz medijacijskih veza u kojima je postojao vremenski razmak između roditeljskih i učeničkih varijabli, ali ne i između roditeljskih uvjerenja i ponašanja te učeničkih motivacijskih uvjerenja i iskaza o bavljenju slobodnim aktivnostima. 
Istraživanja pokazuju da bi za potpuno nepristrano testiranje medijacijskih hipoteza trebalo koristiti longitudinalne modele (Maxwell i Cole, 2007).

Naposljetku, treba napomenuti da je uzorak učenika u ovom istraživanju u određenoj mjeri selekcioniran. Naime, pokazalo se da su učenici čiji su roditelji sudjelovali u istraživanju imali nešto više školsko postignuće iz matematike te su izvijestili o nešto višoj samoefikasnosti u matematici od učenika čiji roditelji nisu sudjelovali u istraživanju. Ova pristranost uzorka mogla se odraziti na rezultate dobivene u modelima iz matematike $u$ vidu podcjenjivanja dobivenih efekata zbog smanjene varijance rezultata $u$ varijablama postignuća i samoefikasnosti u matematici. Također, iako to nije bilo moguće provjeriti, postoji mogućnost $\mathrm{i}$ da se roditelji koji nisu sudjelovali u istraživanju bitno razlikuju u nekima od ispitivanih varijabli od roditelja koji su pristali sudjelovati.

\section{8. Znanstveni i praktični doprinosi istraživanja}

Znanstveni doprinosi ovog istraživanja mogu se podijeliti u dvije skupine. Prva skupina tiče se samih istraživačkih problema. Naime, kroz ispitane probleme smo doprinijeli spoznajama o nekim nedovoljno istraženim elementima modela roditeljske socijalizacije dječjih obrazovnih ishoda Eccles i suradnika, ali i spoznajama o socijalizaciji u STEM području obrazovanja. Najprije, unutar istog modela smo ispitali utjecaje proksimalnih i distalnih roditeljskih karakteristika na učeničke obrazovne ishode u matematici i tehničkoj kulturi, dok se većina istraživanja do sad bavila poveznicom između egzogenih elemenata modela roditeljske socijalizacije dječjih obrazovnih ishoda (opća roditeljska i djetetova obilježja) i ostalih roditeljskih i dječjih konstrukata u modelu (Wigfield i sur., 2015).

Također, do sad su rijetko unutar istog modela ispitana i roditeljska uvjerenja i roditeljska ponašanja, što omogućava testiranje medijacijskih mehanizama pretpostavljenih modelom roditeljske socijalizacije dječjih obrazovnih ishoda. Pregledom dostupne literature pronašli smo samo jedno istraživanje koje su provele Simpkins i suradnice (2012), a u kojem je unutar jedinstvenog modela provjerena cjelovita sekvenca utjecaja roditeljska uvjerenja roditeljska ponašanja - dječja uvjerenja - dječja ponašanja. U našem smo istraživanju u cijelosti provjerili ove medijacijske mehanizme, ali i izravne veze između ovih konstrukata, te time ukazali na dijelove modela roditeljske socijalizacije dječjih obrazovnih ishoda koji dobivaju manju, odnosno, veću empirijsku podršku. Nadalje, relativno je mali broj radova u kojima je unutar jednog istraživanja provjeren utjecaj različitih vrsta roditeljskih ponašanja na 
učeničke obrazovne ishode (Simpkins i sur., 2015a; Wigfield i sur., 2015), kao što je slučaj u našem istraživanju.

Ispitivanje različitih izvora roditeljskih utjecaja nam je omogućilo i njihovu međusobnu usporedbu te zaključivanje o nezavisnom doprinosu svakog od njih u predviđanju učeničkih obrazovnih ishoda. Provjera moderatorskog utjecaja obrazovanja roditelja i roda učenika je također dosad rijetko istraživana (Simpkins i sur., 2012), a može imati značajne implikacije za moguće smjernice za praksu koje će biti objašnjene kasnije u ovom poglavlju.

Osim što smo kroz istraživačke probleme zahvatili veliki dio modela roditeljske socijalizacije dječjih obrazovnih ishoda, doprinos našeg istraživanja predstavlja i ispitivanje različitih učeničkih obrazovnih ishoda koji su konceptualizirani modelom očekivanja i vrijednosti. Ovo istraživanje time pridonosi spoznajama o tome kako različiti roditeljski utjecaji u STEM području objašnjavaju ne samo učeničko postignuće, što je do sada dominantno istraživano, već i različita učenička motivacijska uvjerenja te odabir aktivnosti. Time smo također dali doprinos spoznajama o tome kako su različita motivacijska uvjerenja učenika uključena u neizravan utjecaj roditelja na školsko postignuće te na bavljenje aktivnostima $u$ STEM području.

Doprinos ovog istraživanja predstavlja i provjera modela $u$ dva različita STEM obrazovna područja. Naime, ostala istraživanja su do sad većinom bila usmjerena ili isključivo na matematiku ili na prirodoslovlje. U tom kontekstu, prednost istraživanja je i provjera roditeljskih utjecaja u STEM školskom području koje do sad nije istraženo, a odnosi se na područje tehničkog obrazovanja u osnovnoj školi. Naši rezultati ukazuju na određene razlike u socijalizacijskim mehanizmima u matematici i tehničkoj kulturi što potvrđuje tezu o važnosti heterogene konceptualizacije STEM obrazovnog područja.

Kada govorimo o korištenoj metodologiji, prvi doprinos predstavljaju korištene mjere konstrukata koje su orijentirane na matematiku i tehničku kulturu. Naime, kao što napominju Wigfield i suradnici (2015), nedostatak prijašnjih istraživanja socijalizacijskih utjecaja u objašnjavanju učeničke motivacije za postignućem je što ih se većina bavila općim, a ne područno-specifičnim roditeljskim i učeničkim konstruktima. Drugi metodološki doprinos našeg istraživanja odnosi se na prikupljanje roditeljskih i učeničkih podataka u različitim vremenskim točkama. Iako je za zaključivanje o uzročno-posljedičnim vezama nužan već spomenuti križni longitudinalni nacrt, u kojem su sve roditeljske i učeničke varijable odmjerene više puta, vremenski odmak između prikupljanja učeničkih i roditeljskih varijabli predstavlja metodološki snažniji nacrt u odnosu na potpuno transverzalna istraživanja koja su najčešća $u$ ovom području. 
Također treba napomenuti da smo uključivanjem mjere učeničkog prethodnog i kasnijeg postignuća ipak kontrolirali jedan dio dvosmjernih utjecaja roditelj - dijete. Naime, pozitivna korelacija između roditeljskih uvjerenja i učeničkog postignuća može biti zapravo posljedica obrnutog smjera utjecaja - više učeničko postignuće dovodi do viših roditeljskih uvjerenja o djetetu. Iako je stoga nužno kontrolirati prethodno učeničko postignuće, to je do sad bila praksa u samo manjem broju istraživanja (Murayama, Pekrun, Suzuki, Marsh i Lichtenfeld, 2016). Stoga je prednost našeg istraživanja što smo mogli procijeniti u kojoj mjeri roditeljska uvjerenja i ponašanja utječu na učeničke obrazovne ishode nezavisno od prethodnog postignuća učenika koje može biti konfundirajuća varijabla u ispitivanju ovih veza. Međutim, kako napominju Briley i suradnici (2014), i druge inicijalne karakteristike djeteta kao što su raniji interes za predmet, uvjerenja o sposobnostima i opća akademska ponašanja mogu utjecati na roditeljska uvjerenja i ponašanja pa bi i njih trebalo kontrolirati u budućim istraživanjima.

Budući da se učenje STEM sadržaja događa u školi, ali i izvan škole (Sha i sur., 2016), prednost našeg istraživanja je što smo osim učeničkih varijabli koje se odnose na matematiku i tehničku kulturu kao nastavne predmete, uključili i učeničko bavljenje aktivnostima u izvanškolskom matematičkom i tehničkom području. Naposljetku, korištena metodologija strukturalnog modeliranja također ima određene metodološke prednosti koje su detaljno opisane u potpoglavlju 3. 4. 1., a koje predstavljaju prednost i u ovom istraživanju s obzirom na postavljene probleme i prirodu ispitivanih varijabli.

Naši rezultati imaju i praktične doprinose koji se prvenstveno odnose na edukaciju roditelja, ali i na uključivanje roditelja $u$ intervencijske programe u STEM obrazovnom području. Naime, roditelji su nedovoljno uključeni u programe kojima je cilj povećanje učeničkog interesa za STEM obrazovanje i karijere (Harackiewicz i sur., 2012). Uključivanje roditelja u programe u području matematike može biti posebice važno u kontekstu rješavanja tzv. STEM problema budući da je postignuće u matematici krucijalno u učeničkom profiliranju prema karijerama u STEM području (NSB, 2010).

Kada govorimo o konkretnim preporukama za edukacijske i intervencijske programe, naši rezultati najprije ukazuju na važnost pozitivnih i visokih roditeljskih uvjerenja vezanih uz dijete u nastavnim predmetima STEM područja kao što su matematika i tehnička kultura. Roditelje treba educirati da njihova uvjerenja o djetetovom potencijalu, interesu i trudu u predmetu te o korisnosti predmeta za dijete i njegovu budućnost mogu značajno utjecati na djetetovu motivaciju i postignuće u STEM školskom području, ali i na način na koji dijete interpretira svoje prijašnje obrazovne uspjehe u ovom području. To posebice vrijedi za 
matematiku budući da se pokazalo da je učenička samoefikasnost u ovom predmetu bila snažnije povezana s roditeljskim uvjerenjima nego s učeničkim prethodnim postignućem.

Iako ta rasprava premašuje nalaze ovog istraživanja, u kontekstu smjernica za praksu ipak treba napomenuti da previsoke roditeljske aspiracije za djetetov uspjeh u školovanju mogu imati negativan učinak na taj uspjeh. U nedavnom pionirskom istraživanju ovog fenomena, Murayama i suradnici (2016) su naznačili važnost razlikovanja roditeljskih aspiracija i očekivanja. Pritom su previsoke aspiracije roditelja definirali kao stupanj u kojem su roditeljske aspiracije (,želim da moje dijete postigne ovaj uspjeh“) premašivale roditeljska očekivanja (,vjerujem da moje dijete može postići ovaj uspjeh“). Roditeljske aspiracije koje su premašivale roditeljska očekivanja su negativno predviđale učenički uspjeh u matematici te je taj utjecaj bio recipročan kroz vrijeme, stvarajući začarani krug međusobnog utjecaja između nižeg uspjeha učenika i previsokih aspiracija roditelja. Autori pretpostavljaju da su previsoka roditeljska kontrola te smanjena učenička samoefikasnost, frustracija i negativne emocije koje nastaju kad roditelji imaju previsoke aspiracije neki od pozadinskih faktora koji mogu objasniti ovaj nalaz. Iako se njihovo istraživanje nije bavilo time imaju li i previsoka roditeljska uvjerenja o djetetovoj sposobnosti i očekivanja uspjeha isti negativan efekt na učeničko postignuće, možemo pretpostaviti da poveznica između roditeljskih uvjerenja i očekivanja i učeničkog uspjeha također nije u potpunosti linearna. U već spomenutom istraživanju kojeg su proveli Gniewosz i Watt (2017), roditeljsko precjenjivanje djetetovih sposobnosti u matematici bilo je pozitivno povezano $\mathrm{s}$ promjenom $\mathrm{u}$ interesu $\mathrm{i}$ percepciji korisnosti matematike kod adolescenata. Međutim, autori također navode da je moguće da roditeljska uvjerenja koja su nerealistično visoka mogu imati suprotni učinak na učeničku motivaciju. Iako ova pitanja zahtijevaju dodatna istraživanja, dosadašnji nalazi upućuju na zaključak da treba poticati visoka i pozitivna uvjerenja i očekivanja kod roditelja, no da ona ipak trebaju u većoj mjeri biti usklađena s učeničkim stvarnim sposobnostima i afinitetima kako bi se ostvarili optimalni socijalizacijski učinci.

Roditelje također treba educirati na koji način kroz različite prakse kod kuće mogu komunicirati svoja uvjerenja u periodu adolescencije. Naši nalazi upućuju da u matematici roditelji barem dijelom komuniciraju svoja negativnija uvjerenja kroz učestalije uključivanje u djetetove školske obaveze iz matematike, dok pozitivnija uvjerenja komuniciraju preko češćeg poticanja djetetovog interesa za matematičke izvanškolske aktivnosti. Istaknutu važnost roditeljskih uvjerenja kao socijalizacijskih mehanizama u STEM području moguće je iskoristiti i u intervencijskim programima. Primjerice, Harackiewicz i suradnici (2012) su proveli jednostavnu intervenciju $u$ kojoj $\mathrm{su}$ roditelji dobili brošure $\mathrm{i}$ pristup web stranici $\mathrm{s}$ 
informacijama o važnosti matematike i prirodoslovlja za svakodnevni život i za pojedina zanimanja, kao i savjete kako kroz razgovor s adolescentima povezati sadržaje ovih predmeta s njihovim životom. Pokazalo se da je ova intervencija povećala roditeljsku percepciju korisnosti STEM područja, a preko toga i učeničku percepciju korisnosti.

Roditelje također treba educirati da različita ponašanja kod kuće imaju različiti potencijal u oblikovanju učeničkih ishoda u matematičkom i tehničkom području obrazovanja. Pri educiranju roditelja, važno je u obzir i razvojni kontekst, kao i opće kvalitativne dimenzije roditeljstva, koje nisu ispitane u ovom istraživanju, no mogu utjecati na učinkovitost specifičnih roditeljskih praksi. Najprije, roditelje treba educirati da njihova uključenost u učeničke obaveze iz ovih nastavnih predmeta u periodu adolescencije ili ne pridonosi učeničkim obrazovanim ishodima ili čak na njih može negativno djelovati. Roditeljima bi svakako trebalo objasniti i moguće razloge tog nalaza koji su raspravljeni u potpoglavlju 5. 3. 2., a koji se odnose na razinu kontrole u takvom roditeljskom interveniranju, komunikaciju negativnih uvjerenja o djetetu te neusklađenost ovog ponašanja s razvojnim zadacima adolescencije.

S druge strane, kroz savjetovanje i edukaciju te kroz kontinuirani razvoj partnerstva između roditelja i škola, roditelje se treba upoznati s važnošću interakcija s djetetom koje nisu nužno usmjerene na djetetove školske obaveze u nastavnim predmetima STEM područja, već na komuniciranje vrijednosti STEM školskog i izvanškolskog područja te poticanje interesa za informalne aktivnosti u STEM području. Roditelji pritom ne trebaju imati ekspertno znanje u STEM području kako bi provodili ova ponašanja (Simpkins i sur., 2015c). U našem smo istraživanju pokazali da poticanje interesa za matematičke aktivnosti izvan škole može povoljno utjecati na učenički interes za matematiku kao nastavni predmet. Slična roditeljska ponašanja moguće je stimulirati i u intervencijskim programima. Primjerice, u istraživanju koje je spomenuto u prethodnom odlomku, Harackiewicz i suradnici (2012) su pokazali da je provedena intervencija povećala i učestalost komunikacije roditelja s djetetom o važnosti nastavnih predmeta STEM područja i o obrazovnim planovima učenika u tom području, što je pak pozitivno djelovalo na učeničku percepciju korisnosti matematike i prirodoslovlja u adolescenciji. Uključivanje roditelja u programe usmjerene na povećanje ili održavanje učeničkog interesa može biti posebice važno u matematici budući da istraživanja ističu upravo matematiku kao nastavni predmet u kojem dolazi do značajnog pada učeničkog interesa $\mathrm{u}$ srednjoj školi (Frenzel, Goetz, Pekrun i Watt, 2010; Jacobs i sur., 2002; Watt, 2004).

Kada govorimo o roditeljskom modeliranju, naši nalazi sugeriraju da iako ono nema socijalizacijski potencijal u matematičkom području, može pozitivno utjecati na učeničku vrijednost tehničke kulture, a preko toga i na učeničko bavljenje tehničkim aktivnostima. Stoga 
se i ovo roditeljsko ponašanje može iskoristiti u intervencijskim programima kojima je cilj povećanje učeničkog interesa za tehničko obrazovanje i tehničke karijere. Naši rezultati također ukazuju da je umjesto pribavljanja materijala koji potiču učenje u STEM području važnije poticati kognitivni i afektivni angažman roditelja u STEM obrazovnom području. To je posebice važna implikacija za obitelji nižeg SES-a kojima možda nedostaje materijalnih resursa u ovom području, no koje svejedno mogu poticati pozitivne obrazovne ishode u STEM području svoje djece kroz visoka uvjerenja i adekvatne roditeljske prakse (Sha i sur., 2016).

Naposljetku, naši nalazi vezani uz roditeljska ponašanja ukazuju da bi stimulacija određenih ponašanja roditelja u STEM području mogla imati pozitivan učinak prvenstveno na učeničku vrijednost ovog područja, ali ne i na učeničku samoefikasnost u ovom području.

U našem su istraživanju obrazovaniji roditelji imali negativnija uvjerenja vezana uz svoje dijete u tehničkoj kulturi, a učenici obrazovanijih roditelja niži interes i percepciju važnosti ovog predmeta. Ovaj nalaz ima određene implikacije za obrazovne politike u tehničkom području. Naime zadnjih je godina u razvijenim zemljama svijeta prisutan problem slabog interesa učenika za zanimanja i obrazovanje u području tehnike $\mathrm{i}$ inženjerstva (Johansson, 2009; OECD, 2008). Stoga bi nacionalne obrazovne politike trebale težiti tome da tehničko obrazovanje bude jednako privlačno svim učenicima, bez obzira na njihov SES. Kao što je objašnjeno u potpoglavlju 5. 1. 1., moguće je da obrazovaniji roditelji i njihova djeca imaju negativnija uvjerenja vezana uz tehničku kulturu jer je ovaj predmet kod nas važan samo za upis srednjih strukovnih škola koje su manje privlačna obrazovna opcija roditeljima i učenicima višeg SES-a. Pored toga, skroman udio tehničkog područja nastave u nacionalnom kurikulumu također može umanjiti percepciju važnosti ovog područja obrazovanja za budući profesionalni i obrazovni razvoj učenika u odnosu na druge predmete. To može biti posebice izraženo kod obitelji višeg SES-a budući da djeca i roditelji iz ovih obitelji imaju više opće obrazovne aspiracije. Iz ovih je razloga važno da kroz nastavu tehničke kulture učenici povezuju sadržaje iz ovog predmeta sa sadržajem mnogih, danas visoko traženih zanimanja, kao i s brojnim studijskim programima u STEM području visokog obrazovanja. Naime, istraživanja pokazuju da učenici vrlo često imaju ograničena znanja o tome koja znanja i vještine su važne za karijere u STEM području (Bøe i Henriksen, 2013). Ostvarivanje ovakvih poveznica može kod učenika višeg (ali i nižeg) SES-a povećati percepciju korisnosti tehničkih znanja i vještina za njihov budući obrazovni i profesionalni put, a time pozitivno djelovati i na njihov interes za ovaj predmet. Naime, eksperimentalna istraživanja pokazuju da percepcija korisnosti određenog područja može direktno utjecati na razvijanje i održavanje interesa za to područje (Hulleman i sur., 2010). Kroz izborne predmete, izvannastavne sadržaje i razvojne 
programe, obrazovne politike trebaju u većoj mjeri promovirati tehnička znanja i vještine i prikazivati ih kao vrijedan dio STEM područja. Takve aktivnosti mogu potaknuti i roditelje višeg SES-a da prepoznaju vrijednost ovog područja u obrazovnom i profesionalnom razvoju njihove djece.

Nalazi vezani uz drugi istraživački problem ukazuju da edukativni i intervencijski programi mogu ciljati na iste socijalizacijske mehanizme kod roditelja, bez obzira na rod djeteta. Međutim, roditeljima nižeg SES-a može biti potrebna veća podrška u provođenju socijalizacijskih praksi u matematici. Kako bi se roditelje nižeg SES-a osnažilo u njihovim podržavajućim interakcijama s djetetom u školskom i izvanškolskom matematičkom području, potrebno je raditi na njihovoj samoefikasnosti u matematici, kao i osnažiti njihovu predodžbu njihove aktivne uloge u obrazovnom i profesionalnom razvoju djeteta. Naime, kao što je raspravljeno u poglavlju 5. 6., istraživanja pokazuju da ova roditeljska uvjerenja utječu na različite oblike roditeljske uključenosti, a pritom su slabije izražena kod roditelja nižeg SES-a. Kako bi se ojačala roditeljska percepcija aktivne uloge u obrazovnom razvoju djeteta te roditeljska samoefikasnost, nastavnici i stručni suradnici bi kroz svoj rad s roditeljima trebali pokušati postići da svi roditelji, bez obzira na svoj stupanj obrazovanja, imaju pozitivan utjecaj na obrazovne ishode svoje djece te da čak i kad zahtjevi školovanja premašuju znanje roditelja, roditeljska ponašanja poticanja, podrške i modeliranja imaju pozitivan utjecaj na djetetov obrazovni napredak (Hoover-Dempsey i sur., 2005).

Naposljetku treba naglasiti da bi u razvoj adekvatnih edukacijskih i intervencijskih programa za roditelje bilo korisno uključiti i učenike. Naime, iako u ovom istraživanju nismo uključili takve mjere, samo one roditeljske aktivnosti koje učenici uistinu percipiraju kao podržavajuće mogu imati pozitivni učinak na njihove obrazovne ishode (Jacobs i Bleeker, 2004). 


\section{ZAKLJUČAK}

Cilj ovog istraživanja bio je ispitati roditeljske odrednice učeničkih motivacijskih uvjerenja, slobodnih aktivnosti te školskog postignuća u matematici i tehničkoj kulturi kao dva STEM školska područja. U okviru prvog istraživačkog problema ispitan je niz izravnih i neizravnih odnosa između roditeljskih utjecaja i učeničkih obrazovnih ishoda. Obrazovanje roditelja nije imalo nezavisan doprinos $\mathrm{u}$ predviđanju učeničkih obrazovnih ishoda $\mathrm{u}$ matematici. Obrazovanje roditelja također nije predviđao roditeljska uvjerenja u matematici koja su primarno bila pod utjecajem prošlog učeničkog postignuća iz matematike. Suprotno očekivanjima, više obrazovani roditelji imali su negativnija uvjerenja vezana uz svoju djecu u tehničkoj kulturi, a učenici obrazovanijih roditelja nižu motivaciju za ovaj predmet od učenika čiji su roditelji manje obrazovani. Negativan učinak obrazovanja roditelja na učeničku samoefikasnost $\mathrm{u}$ tehničkoj kulturi bio je u potpunosti neizravan te se ostvarivao preko negativnijih roditeljskih uvjerenja, dok je negativan učinak obrazovanja roditelja na interes $i$ važnost tehničke kulture bio izravan. Obrazovanje roditelja je tek u manjoj mjeri predviđalo roditeljska ponašanja u STEM području - pozitivno je predviđao roditeljsko pribavljanje STEM materijala te poticanje djetetovih interesa za tehničke aktivnosti.

U skladu s hipotezama, roditeljska uvjerenja potvrđena su kao značajni, umjereni do snažni prediktor svih učeničkih motivacijskih uvjerenja u oba predmeta. Rezultati sugeriraju da su roditeljske evaluacije djeteta u predmetu važniji izvor informacija na kojima učenici grade pojam o sebi u predmetu nego prethodni uspjeh iz predmeta. Također je potvrđena hipoteza o roditeljima kao "tumačima stvarnosti" budući da je u oba nastavna predmeta pronađen značajni medijacijski učinak roditeljskih uvjerenja u objašnjavanju poveznice između učeničkog prošlog postignuća i kasnije samoefikasnosti u predmetu. U matematici su roditeljska uvjerenja predviđala učeničko postignuće dijelom izravno, a dijelom neizravno preko više učeničke samoefikasnosti. U tehničkoj kulturi su roditeljska uvjerenja predviđala učeničko postignuće neizravno, preko više samoefikasnosti. Roditeljska uvjerenja su pozitivno predviđala roditeljsko poticanje interesa za matematičke i tehničke aktivnosti i roditeljsko pribavljanje STEM materijala. Negativnija roditeljska uvjerenja predviđala su češću roditeljsku uključenost u djetetove obaveze iz matematike. Roditeljska uvjerenja predviđala su viši učenički interes za matematiku i dijelom neizravno - preko češćeg roditeljskog poticanja djetetovih interesa za matematičke aktivnosti te preko rjeđe roditeljske uključenosti u djetetove obaveze iz matematike. Ipak, medijacijska uloga roditeljskih ponašanja u objašnjenju povezanosti između 
roditeljskih uvjerenja i učeničkih motivacijskih uvjerenja većinom nije potvrđena budući da su roditeljska ponašanja bila slabi prediktori učeničke motivacije.

Nalazi vezani uz roditeljska ponašanja ukazuju na značajne razlike s obzirom na nastavni predmet. Roditeljsko modeliranje nije imalo prediktivni efekt ni za jedan od učeničkih ishoda u matematici. S druge strane, roditeljsko modeliranje predviđalo je viši učenički interes i veću važnost tehničke kulture. Također, preko pozitivnog efekta na učeničke vrijednosti tehničke kulture, roditeljsko modeliranje je pozitivno predviđalo i učeničko bavljenje tehničkim aktivnostima u slobodno vrijeme. Roditeljska uključenost u učeničke obaveze iz predmeta je imala negativni prediktivni učinak samo u matematici. Naime, roditeljska uključenost $u$ učeničke obaveze iz matematike je izravno negativno predviđala učenički interes za matematiku te preko nižeg interesa i rjeđe učeničko bavljenje matematičkim aktivnostima $u$ slobodno vrijeme. Roditeljsko poticanje interesa je pozitivno predviđalo učeničko bavljenje matematičkim i tehničkim aktivnostima u slobodno vrijeme te učenički interes za matematiku. Naposljetku, roditeljsko pribavljanje STEM materijala pokazalo se kao neznačajan prediktor učeničkih obrazovnih ishoda u oba predmeta. Sveobuhvatno gledano, roditeljska uvjerenja su potvrđena kao snažniji i konzistentniji prediktori učeničkih obrazovnih ishoda u matematici i tehničkoj kulturi nego roditeljska ponašanja.

U okviru drugog istraživačkog problema, hipoteza o rodnoj invarijantnosti modela je većim dijelom potvrđena u oba predmeta. Međutim, utvrđene su određene strukturalne razlike u modelu iz matematike s obzirom na obrazovanje roditelja. Negativnija roditeljska uvjerenja bila su povezana s češćom uključenosti roditelja u obje obrazovne skupine, no ta je povezanost bila snažnija kod roditelja višeg obrazovanja. Također, roditeljska uvjerenja su bila značajno pozitivno povezana s roditeljskim poticanjem djetetovih interesa za matematiku u skupini više obrazovanih roditelja, ali ne i u skupini niže obrazovanih roditelja.

Različita uloga roditeljskih osobnih karakteristika, uvjerenja i ponašanja $u$ objašnjavanju učeničke motivacije, postignuća i odabira aktivnosti u STEM području oslikava kompleksnost socijalizacijskih procesa u STEM području obrazovanja u ranoj adolescenciji. Rezultati također ukazuju da je za potpunije razumijevanje socijalizacije u ovom obrazovnom području potrebno u obzir uzeti i roditeljske i učeničke medijacijske mehanizme. Naime, u ovom su istraživanju učenička motivacijska uvjerenja imala važnu medijacijsku ulogu u objašnjavanju mehanizama roditeljskih utjecaja, što je naglašeno i u suvremenoj teoriji očekivanja i vrijednosti. Dobiveni rezultati također impliciraju da se mehanizmi socijalizacije mogu razlikovati s obzirom na socioekonomsku pozadinu obitelji, ali i specifičnu STEM disciplinu. Provedeno istraživanje tako ukazuje da je za šire razumijevanje procesa 
socijalizacije u STEM obrazovnom području važno ispitivati modele koji integriraju različite roditeljske utjecaje i različite učeničke obrazovne ishode, ispituju medijacijske i moderatorske hipoteze, uključuju usporedbu socijalizacijskih mehanizama u različitim disciplinama STEM obrazovnog područja te koriste longitudinalne nacrte istraživanja. 


\section{LITERATURA}

Acosta, S. i Hsu, H. Y. (2014). Shared academic values: testing a model of the association between Hong Kong parents' and adolescents' perception of the general value of science and scientific literacy. Educational Studies, 40(2), 174-195.

Adams, C. R. i Singh, K. (1998). Direct and indirect effects of school learning variables on the academic achievement of African American 10th graders. Journal of Negro Education, 67(1), 48-66.

Aeschlimann, B., Herzog, W. i Makarovac, E. (2016). How to foster students' motivation in mathematics and science classes and promote students' STEM career choice. A study in Swiss high schools. International Journal of Educational Research, 79, 31-41.

Alexander, K. L., Entwisle, D. R. i Bedinger, S. D. (1994) When expectations work: race and socioeconomic differences in school performance, Social Psychology Quarterly, 57(4), 283-299.

Allison, P. D. (2003). Missing data techniques for structural equation modeling. Journal of Abnormal Psychology, 112(4), 545-557.

American Association for the Advancement of Science [AAAS]. (2001). A public awareness initiative to build support for science literacy. Washington, DC.

Anders, Y., Rossbach, H. G., Weinert, S., Ebert, S., Kuger, S., Lehrl, S. i von Maurice, J. (2012). Home and preschool learning environments and their relations to the development of early numeracy skills. Early Childhood Research Quarterly, 27(2), 231244.

Anderson, A., Anderson, J. i Shapiro, J. (2004). Mathematical discourse in shared storybook reading. Journal for Research in Mathematics Education, 35(1), 5-33.

Anderson, J. C. i Gerbing, D.W. (1988). Structural equation modeling in practice: A review and recommended two-step approach. Psychological Bulletin 103(3), 411-423.

Andre, T., Whigham, M., Hendrickson, A. i Chambers, S. (1999). Competency beliefs, positive affect, and gender stereotypes of elementary students and their parents about science versus other school subjects. Journal of Research in Science Teaching, 36(6), 719-747.

Arbuckle, J. L. i Wothke, W. (1999). Amos users' guide, Version 4.0. Chicago: Small Waters Corporation.

Archer, L. (2010, rujan). 'Science is not for me?': exploring children's and families' engagement with science through the lens of identity. Rad prezentiran na BERA konferenciji, Coventry, Ujedinjeno Kraljevstvo. 
Archer, L., DeWitt, J., Osborne, J., Dillon, J., Willis, B. i Wong, B. (2012). Science aspirations, capital, and family habitus: How families shape children's engagement and identification with science. American Educational Research Journal, 49, 881-908.

Archer, L., Dewitt, J. i Willis, B. (2014). Adolescent boys' science aspirations: Masculinity, capital and power. Journal of Research in Science Teaching, 51(1), 1-30.

Archer, L., Osborne, J., DeWitt, J., Dillon, J., Wong, B. i Willis, B. (2013). ASPIRES: Young people's science and career aspirations, age 10-14. London: King's College London.

Arens, A. K., Marsh, H. W., Pekrun, R., Lichtenfeld, S., Murayama, K. i vom Hofe, R. (2017). Math self-concept, grades, and achievement test scores: Long-term reciprocal effects across five waves and three achievement tracks. Journal of Educational Psychology, 109(5), 621-634.

Ashcraft, M. H. (2002). Math anxiety: Personal, educational, and cognitive consequences. Current Directions in Psychological Science, 11(5), 181-185.

Astin, A. W. i Astin, H. S. (1992). Undergraduate science education: The impact of different college environments on the educational pipeline in the sciences. Los Angeles, CA: University of California, Graduate School of Education, Higher Education Research Institute.

Atkinson, J. W. (1957). Motivational determinants of risk taking behavior. Psychological Review, 64(6, Pt.1), 359-372.

Atkinson, J. W. (1964). An introduction to motivation. Princeton, NJ: Van Nostrand.

Aunola, K. i Nurmi, J. E. (2004). Maternal affection moderates the impact of psychological control on a child's mathematical performance. Developmental Psychology, 40(6), 965978.

Aunola, K., Nurmi, J. E., Lerkkanen, M. K. i Rasku-Puttonen, H. (2003). The roles of achievement-related behaviours and parental beliefs in children's mathematical performance. Educational Psychology, 23(4), 403-421.

Babarović, T., Burušić, J. i Šakić, M. (2009). Uspješnost predviđanja obrazovnih postignuća učenika osnovnih škola Republike Hrvatske. Društvena Istraživanja, 18(4-5), 673-695.

Babarović, T., Burušić, J. i Šakić, M. (2012, rujan). Class size and student/teacher ratio as determinants of student achievement in primary school: Evidence from Croatia. Rad prezentiran na European Conference on Educational Research, Cadiz, Španjolska.

Bachman, H. J., Votruba-Drzal, E., El Nokali, N. E. i Castle Heatly, M. (2015). Opportunities for learning math in elementary school: Implications for SES disparities in procedural and conceptual math skills. American Educational Research Journal, 52(5), 894-923.

Balboni, G. i Pedrabissi, L. (1998). School adjustment and academic achievement: Parental expectations and socio-cultural background. Early Child Development and Care, 143(1), 79-93. 
Bandura, A. (1986). Social foundations of thought and action: A social cognitive theory. Englewood Cliffs, NJ: Prentice Hall.

Bandura, A. (1997). Social cognitive theory. U R. Vasta (Ur.), Six theories of child development (str. 1-60). London: Jessica Kingsley.

Bandura, A. i Walters, R. (1963). Social learning and personality development. New York: Holt, Rinehart \& Winston.

Banks, F. i Barlex, D. (2014). Teaching STEM in the secondary school: Helping teachers meet the challenge. London: Routledge.

Bao, L., Cai, T., Koenig, K., Fang, K., Han, J., Wang, J., Liu, Q., Ding, L., Cui, L., Luo, Y., Wang, Y., Li, L. i Wu, N. (2009). Learning and scientific reasoning. Science, 323(5914), 586-587.

Barrett, B. S., Moran, A. L. i Woods, J. E. (2014). Meteorology meets engineering: an interdisciplinary STEM module for middle and early secondary school students. International Journal of STEM Education, 1(1), 1-6.

Barron, K. E. i Hulleman, C. S. (2015). Expectancy-value-cost model of motivation. U J. D. Wright (Ur.), International encyclopedia of the social \& behavioral sciences, 2nd edition (str. 503-509). Oxford: Elsevier Ltd.

Bell, D. (2016). The reality of STEM education, design and technology teachers' perceptions: A phenomenographic study. International Journal of Technology and Design Education, 26(1), 61-79.

Berkowitz, T., Schaeffer, M. W., Maloney, E. A., Peterson, L., Gregor, C., Levine, S. C. i Beilock, S. L. (2015). Math at home adds up to achievement in school. Science, 350(6257), 196-198.

Bhanot, R. T. i Jovanovic, J. (2005). Do parents' academic gender stereotypes influence whether they intrude on their children's homework?. Sex Roles, 52(9), 597-607.

Bhanot, R. T. i Jovanovic, J. (2009). The links between parent behaviors and boys' and girls' science achievement beliefs. Applied Developmental Science, 13(1), $42-59$.

Bleeker, M. M. i Jacobs, J. E. (2004). Achievement in math and science: Do mothers' beliefs matter 12 years later?. Journal of Educational Psychology, 96(1), 97-109.

Bøe, M. V. i Henriksen, E. K. (2013). Love it or leave it: Norwegian students' motivations and expectations for postcompulsory physics. Science Education, 97(4), 550-573.

Bøe, M. V., Henriksen, E. K., Lyons, T. i Schreiner, C. (2011). Participation in science and technology: young people's achievement-related choices in late-modern societies. Studies in Science Education, 47(1), 37-72.

Boonk, L., Gijselaers, H. J., Ritzen, H. i Brand-Gruwel, S. (2018). A review of the relationship between parental involvement indicators and academic achievement. Educational Research Review, 24, 10-30. 
Bourdieu, P. (1986). Forms of capital. U J. Richardson (Ur.), Handbook of theory and research for the sociology of education (str. 241-258). New York: Greenwood.

Bozick, R. i Ingels, S. J. (2008). Mathematics course taking and achievement at the end of high school: Evidence from the Education Longitudinal Study of 2002 (ELS: 2002) (Statistical Analysis Report NCES 2008-319). Washington, DC: National Center for Education Statistics.

Braš Roth, M. (2016). Rezultati OECD-ova istraživanja PISA 2015. Preuzeto 6. srpnja 2019. s https://www.ncvvo.hr/objava-rezultata-oecd-ova-medunarodnoga-istrazivanja-pisa-

$\underline{2015 /}$

Braš Roth, M., Markočić Dekanić, A. i Markuš Sandrić, M. (2017). PISA 2015 Prirodoslovne kompetencije za život. Zagreb: Nacionalni centar za vanjsko vrednovanje obrazovanja.

Breakwell, G. M. i Beardsell, S. (1992). Gender, parental and peer influences upon science attitudes and activities. Public Understanding of Science, 1(2), 183-197.

Breiner, J., Harkness, M., Johnson, C. C. i Koehler, C. (2012). What is STEM? A discussion about conceptions of STEM in education and partnerships. School Science and Mathematics, 112(1), 3-11.

Briley, D. A., Harden, K. P. i Tucker-Drob, E. M. (2014). Child characteristics and parental educational expectations: evidence for transmission with transaction. Developmental Psychology, 50(12), 2614-2632.

Bronfenbrenner, U. (1979). The ecology of human development. Cambridge: Harvard University Press.

Bronfenbrenner, U. i Ceci, S. J. (1994). Nature-nuture reconceptualized in developmental perspective: A bioecological model. Psychological Review, 101(4), 568-586.

Brown, T. A. (2015). Confirmatory factor analysis for applied research: Second edition. New York: Guilford Press.

Bureau of Labor Statistics. (2012). Employment projections - 2010-20. Preuzeto s https://www.bls.gov/news.release/archives/ecopro_02012012.pdf

Byrne, B. M., Shavelson, R. J. i Muthén, B. O. (1989). Testing for equivalence of factor covariance and mean structures: The issue of partial measurement invariance. Psychological Bulletin, 105(3), 456-466.

Campbell, J. R. i Mandel, F. (1990). Connecting math achievement to parental influences. Contemporary Educational Psychology, 15(1), 64-74.

Cannon, J. i Ginsburg, H. P. (2008). "Doing the math": Maternal beliefs about early mathematics versus language learning. Early Education and Development, 19(2), 238260. 
Capraro, R. M., Capraro, M. M. i Morgan, J. R. (2013). STEM project-based learning: An integrated science, technology, engineering, and mathematics (STEM) Approach (2nd Edition). Rotterdam, The Netherlands: Sense.

Cardoso, M. L. i Solomon, J. (2002). Studies of Portuguese and British primary pupils learning science through simple activities in the home. International Journal of Science Education, 24(1), 47-60.

Carmichael, C. i MacDonald, A. (2016). Parental influences on primary school children's mathematics achievement: insights from the Longitudinal Study of Australian Children. Education 3-13, 44(2), 197-211.

Carolan, B. V. i Wasserman, S. J. (2015). Does parenting style matter? Concerted cultivation, educational expectations, and the transmission of educational advantage. Sociological Perspectives, 58(2), 168-186.

Cheadle, J. E. (2008). Educational investment, family context, and children's math and reading growth from kindergarten through the third grade. Sociology of Education, $81(1), 1-31$.

Chouinard, R., Karsenti, T. i Roy, N. (2007). Relations among competence beliefs, utility value, achievement goals, and effort in mathematics. British Journal of Educational Psychology, 77(3), 501-517.

Cieciuch, J., Davidov, E., Schmidt, P., Algesheimer, R. i Schwartz, S. H. (2014). Comparing results of an exact vs. an approximate (Bayesian) measurement invariance test: a cross-country illustration with a scale to measure 19 human values. Frontiers in Psychology, 5, 982.

Cohen, J. (1988). Statistical power analysis for the behavioral sciences (2nd ed.). Hillsdale, NJ: Erlbaum.

Collins, W. A. i Laursen, B. (2004). Parent-adolescent relationships and influences. U R. M. Lerner i L. Steinberg (Ur.), Handbook of adolescent psychology (str. 331-361). Hoboken: Wiley.

Collins, W. A., Maccoby, E. E., Steinberg, L., Hetherington, E. M. i Bornstein, M. H. (2000). Contemporary research on parenting: The case for nature and nurture. American Psychologist, 55(2), 218-232.

Comer, J. P. (1995). School power: Implications of an intervention project. New York: Free Press.

Confederation of British Industry [CBI]. (2015). Inspiring growth CBI/Pearson Education and Skills Survey 2015. Preuzeto s https://www.pearson.com/content/dam/corporate/global/pearson-dot-com/files/pressreleases/2015/CBI-Pearson-Skills-survey-FINAL.pdf

Conley, A. M. (2012). Patterns of motivation beliefs: Combining achievement goal and expectancy-value perspectives. Journal of Educational Psychology, 104(1), 32-47. 
Cooper, H., Lindsay, J. J. i Nye, B. (2000). Homework in the home: How student, family, and parenting-style differences relate to the homework process. Contemporary Educational Psychology, 25, 464-487.

Crowley, K., Callanan, M. A., Tenenbaum, H. R. i Allen, E. (2001). Parents explain more often to boys than to girls during shared scientific thinking. Psychological Science, $12(3), 258-261$.

Dauber, S. L. i Epstein, J. L. (1993). Parents' attitudes and practices of involvement in innercity elementary and middle schools. U N. F. Chavkin (Ur.), Families and schools in a pluralistic society (str. 53-71). Albany: State University of New York Press.

Davis-Kean, P. E. (2005). The influence of parent education and family income on child achievement: the indirect role of parental expectations and the home environment. Journal of Family Psychology, 19, 294-304.

DeBaryshe, B. D. (1995). Maternal belief systems: Linchpin in the home reading process. Journal of Applied Developmental Psychology, 16(1), 1-20.

Deci, E. L. i Ryan, R. M. (1985). Intrinsic motivation and self-determination in human behavior. New York: Plenum.

DeFlorio, L. i Beliakoff, A. (2015). Socioeconomic status and preschoolers' mathematical knowledge: The contribution of home activities and parent beliefs. Early Education and Development, 26(3), 319-341.

Denner, J. (2011). What predicts middle school girls' interest in computing?. International Journal of Gender, Science and Technology, 3(1), 53-61.

Denner, J., Valdes, O., Dickson, D. J. i Laursen, B. (2019). Math interest and self-concept among latino/a students: Reciprocal influences across the transition to middle school. Journal of Adolescence, 75, 22-36.

DeWitt, J. i Archer, L. (2017). Participation in informal science learning experiences: The rich get richer?. International Journal of Science Education, Part B, 7(4), 356-373.

DeWitt, J., Osborne, J., Archer, L., Dillon, J., Willis, B. i Wong, B. (2013). Young children's aspirations in science: The unequivocal, the uncertain and the unthinkable. International Journal of Science Education, 35(6), 1037-1063.

Dickhäuser, O. i Stiensmeier-Pelster, J. (2003). Gender differences in the choice of computer courses: Applying an expectancy-value model. Social Psychology of Education, 6(3), 173-189.

Dierking, L. D. i Falk, J. H. (1994). Family behavior and learning in informal science settings: A review of the research. Science Education, 78(1), 57-72.

Dinkelmann, I. i Buff, A. (2016). Children's and parents' perceptions of parental support and their effects on children's achievement motivation and achievement in mathematics. A 
longitudinal predictive mediation model. Learning and Individual Differences, 50, $122-$ 132.

Dou, R., Hazari, Z., Dabney, K., Sonnert, G. i Sadler, P. (2019). Early informal STEM experiences and STEM identity: The importance of talking science. Science Education, 103(3), 623-637.

Dubow, E. F., Boxer, P. i Huesmann, L. R. (2009). Long-term effects of parents' education on children's educational and occupational success: Mediation by family interactions, child aggression, and teenage aspirations. Merrill-Palmer Quarterly (Wayne State University. Press), 55(3), 224-249.

Duncan, G. J. i Magnuson, K. A. (2005). Can family socioeconomic resources account for racial and ethnic test score gaps?. The Future of Children, 15(1), 35-54.

Duncan, G. J. i Magnuson, K. (2011). The nature and impact of early achievement skills, attention skills, and behavior problems. U G. J. Duncan i R. J. Murnane (Ur.), Whither opportunity: Rising inequality, schools, and children's life chances (str. 47-70). New York: Russell Sage.

Durik, A. M., Vida, M. i Eccles, J. S. (2006). Task values and ability beliefs as predictors of high school literacy choices: A developmental analysis. Journal of Educational Psychology, 98(2), 382-393.

Eccles, J. S. (1993). School and family effects on the ontogeny of children's interests, selfperceptions, and activity choices. U R. Dienstbier i J. E. Jacobs (Ur.), Nebraska Symposium on Motivation: 1992. Developmental perspectives on motivation (Vol. 40, str. 145-208). Lincoln: University of Nebraska Press.

Eccles, J. S. (1994). Understanding women's educational and occupational choices: Applying the Eccles et al. model of achievement-related choices. Psychology of Women Quarterly, 18(4), 585-609.

Eccles, J. S. (2005). Subjective task value and the Eccles et al. model of achievement related choices. U A. J. Elliott i C. S. Dweck (Ur.), Handbook of competence and motivation (str. 105-121). New York: Guilford Publications.

Eccles, J. S. (2007). Families, schools, and developing achievement-related motivations and engagement. U J. E. Grusec i P. D. Hastings (Ur.), Handbook of socialization (str. 665691). New York: The Guilford Press.

Eccles, J. S. (2009). Who am I and what am I going to do with my life? Personal and collective identities as motivators of action. Educational Psychologist, 44(2), 78-89.

Eccles, J. S. (2013). Gender and achievement choices. U E. Gershoff, R. S. Mistry i D. Crosby (Ur.), Societal contexts of child development: Pathways of influence and implications for practice and policy (str. 19-34). New York, NY: Oxford University Press. 
Eccles, J. S. (2015). Gendered socialization of STEM interests in the family. International Journal of Gender, Science and Technology, 7(2), 116-132.

Eccles (Parsons), J. S., Adler, T. F., Futterman, R., Goff, S. B., Kaczala, C. M., Meece, J. L. i Midgley, C. (1983). Expectancies, values, and academic behaviors. U J. T. Spence (Ur.), Achievement and achievement motivation (str. 75-146). San Francisco, CA: W. H. Freeman.

Eccles (Parsons), J. S., Adler, T. F. i Kaczala, C. M. (1982). Socialization of achievement attitudes and beliefs: Parental influences. Child Development, 53(2), 310-321.

Eccles (Parsons), J. S., Adler, T. F. i Meece, J. L. (1984). Sex differences in achievement: A test of alternate theories. Journal of Personality and Social Psychology, 46(1), 26-43.

Eccles, J. S., Freedman-Doan, C., Frome, P., Jacobs, J. i Yoon, K. S. (2000). Gender-role socialization in the family: A longitudinal approach. U T. Eckes i H. M. Trautner (Ur.), The developmental social psychology of gender (str. 333-360). Mahwah, NJ: Lawrence Erlbaum.

Eccles, J. S. i Harold, R. D. (1996). Family participation in children's and adolescents' schooling. U A. Booth i J. Dunn (Ur.), Family-school links: How do they affect educational outcomes (str. 3-34). Mahwah: Lawrence Erlbaum Associates, Inc.

Eccles, J. S. i Jacobs, J. E. (1986). Social forces shape math attitudes and performance. Signs: Journal of Women in Culture and Society, 11(2), 367-380.

Eccles, J. S., Jacobs, J. E. i Harold, R. D. (1990). Gender role stereotypes, expectancy effects, and parents' socialization of gender differences. Journal of Social Issues, 46(2), 183201.

Eccles, J. S., Jacobs, J. E., Harold, R. D., Yoon, K. S., Abreton, A. i Freedman-Doan, C. (1993a). Parents and gender-role socialization during the middle childhood and adolescent years. U S. Oskamp i M. Costanzo (Ur.), Gender issues in contemporary society, Claremont Symposium on Applied Social Psychology, 6 (str. 59-83). Thousand Oaks, CA: Sage.

Eccles, J. S., O’Neill, S. A. i Wigfield, A. (2005). Ability self-perceptions and subjective task values in adolescents and children. U K. Anderson Moore i L. H. Lippman (Ur.), What do children need to flourish? (str. 237-249). New York, NY: Springer.

Eccles, J. S., Vida, M. N. i Barber, B. (2004). The relation of early adolescents' college plans and both academic ability and task-value beliefs to subsequent college enrollment. The Journal of Early Adolescence, 24(1), 63-77.

Eccles, J. i Wang, M. T. (2012). Part I commentary: So what is student engagement anyway? U S. L. Christenson, A. Reschly i C. Wylie (Ur.), Handbook of research on student engagement (str. 133-145). Boston, MA: Springer. 
Eccles, J. S. i Wigfield, A. (1995). In the mind of the actor: The structure of adolescents' achievement task values and expectancy-related beliefs. Personality and Social Psychology Bulletin, 21(3), 215-225.

Eccles, J. S. i Wigfield, A. (2002). Motivational beliefs, values and goals. Annual Review of Psychology, 53, 109-132.

Eccles, J. S., Wigfield, A. i Blumenfeld, P. C. (1984). Psychological predictors of competence development. Bethesda, MD: National Institute of Child Health and Human Development (Grant NO. 2 R01 HD17553-01).

Eccles, J., Wigfield, A., Harold, R. D. i Blumenfeld, P. (1993b). Age and gender differences in children's self and task perceptions during elementary school. Child Development, 64(3), 830-847.

Eccles, J. S., Wigfield, A., Midgley, C., Mac Iver, D. i Feldlaufer, H. (1993). Negative effects of traditional middle schools on students' motivation. Elementary School Journal, 93(5), 553-574.

Eccles, J. S., Wigfield, A. i Schiefele, U. (1998). Motivation to succeed. U N. Eisenberg (Ur.), Handbook of child psychology (5th ed., Vol. III, str. 1017-1095). New York: Wiley.

English, L. D. (2015). STEM: Challenges and Opportunities for Mathematics Education. U K. Beswick, T. Muir, i J. Wells (Ur.), Proceedings of the 39th Conference of the International Group for the Psychology of Mathematics Education (Vol. 1, str. 4-18). Hobart, Australia: PME.

Entwisle, J. i Baker, D. (1983). Gender and young children's expectations for performance in arithmetic. Developmental Psychology, 19(2), 200-209.

Entwisle, D. R. i Hayduk, L. A. (1978). Too great expectations: The academic outlook of young children. Baltimore: John Hopkins University Press.

Epstein, J. L. (1987). Toward a theory of family-school connections: Teacher practices and parent involvement. U K. Hurrelman, F. X. Kaufman i F. Losel (Ur.), Social intervention: Potential and constraints (str. 121-136). Berlin: de Gruyer.

Epstein, J. L. i Sanders, M. G. (2002). Family, school, and community partnerships. U M. H. Bornstein (Ur.), Handbook of parenting: Vol. 5. Practical issues in parenting (str. 407437). Mahwah, NJ: Erlbaum.

Epstein, J. L. i Van Voorhis, F. L. (2001). More than minutes: Teachers' roles in designing homework. Educational Psychologist, 36(3), 181-193.

European Centre for the Development of Vocational Training [Cedefop]. (2016). Skill shortage and surplus occupations in Europe. Preuzeto s http://www.cedefop.europa.eu/files/9115_en.pdf

European Commission [EC]. (2013). Thematic Working Group on mathematics, science and technology: Addressing low achievement in mathematics and science. Preuzeto $\mathrm{s}$ 
http://ec.europa.eu/assets/eac/education/experts-groups/2011-2013/mst/wg-mst-finalreport_en.pdf

Eurostat. (2018). Tertiary education statistics. Preuzeto 13. srpnja 2019. s

https://ec.europa.eu/eurostat/statistics-

explained/index.php?title=Tertiary_education_statistics\#Fields_of_study

Fan, X. i Chen, M. (2001). Parental involvement and students' academic achievement: A meta-analysis. Educational Psychology Review, 13, 1-22.

Fan, W. i Williams, C. M. (2010). The effects of parental involvement on students' academic self-efficacy, engagement and intrinsic motivation. Educational Psychology, 30(1), 5374.

Field, A. P. (2009). Discovering statistics with SPSS (3rd ed.). London: Sage.

Franz-Odendaal, T. A., Blotnicky, K., French, F. i Joy, P. (2016). Experiences and perceptions of STEM subjects, careers, and engagement in STEM activities among middle school students in the maritime provinces. Canadian Journal of Science, Mathematics and Technology Education, 16(2), 153-168.

Fredricks, J. A. i Eccles, J. S. (2002). Children's competence and value beliefs from childhood through adolescence: growth trajectories in two male-sex-typed domains. Developmental Psychology, 38(4), 519-533.

Fredricks, J. A. i Eccles, J. S. (2004). Parental influences on youth involvement in sports. U M. R. Weiss (Ur.), Developmental sport and exercise psychology: A lifespan perspective (str. 145-164). Morgantown, WV: Fitness Information Technology.

Fredricks, J. A. i Eccles, J. S. (2005). Family socialization, gender, motivation, and competitive sports involvement. Journal of Sport \& Exercise Psychology, 27(1), 3-31.

Fredricks, J. A., Simpkins, S. D. i Eccles, J. S. (2005). Family socialization, gender, and participation in sports and instrumental music. U C. R. Cooper, C. T. Garcia Coll, W. T. Bartko, H. Davis i C. Chatman (Ur.), Developmental pathways through middle childhood: Rethinking contexts and diversity as resources (str. 41-62). Mahwah, NJ: Erlbaum.

Frenzel, A. C., Goetz, T., Pekrun, R. i Watt, H. M. G. (2010). Development of mathematics interest in adolescence: Influences of gender, family, and school context. Journal of Research on Adolescence, 20(2), 507-537.

Froiland, J. M. i Davison, M. L. (2016). The longitudinal influences of peers, parents, motivation, and mathematics course-taking on high school math achievement. Learning and Individual Differences, 50, 252-259.

Froiland, J. M., Peterson, A. i Davison, M. L. (2013). The long-term effects of early parent involvement and parent expectation in the USA. School Psychology International, 34(1), 33-50. 
Frome, P. M. i Eccles, J. S. (1998). Parents' influence on children's achievement-related perceptions. Journal of Personality and Social Psychology, 74(2), 435-452.

George, R. i Kaplan, D. (1998). A structural model of parent and teacher influences on science attitudes of eighth graders: Evidence from NELS: 88. Science Education, 82(1), 93-109.

Gerull, F. C. i Bandura, R. M. (2002). Mother knows best: Effects of maternal modelling on the acquisition of fear and avoidance behaviour in toddlers. Behaviour Research and Therapy, 40(3), 279-287.

Gill, S. i Reynolds, A. J. (1999). Educational expectations and school achievement of urban African American children. Journal of School Psychology, 37(4), 403-424.

Gladstone, J. R., Häfner, I., Turci, L., Kneißler, H. i Muenks, K. (2018). Associations between parents and students' motivational beliefs in mathematics and mathematical performance: The role of gender. Contemporary Educational Psychology, 54, 221-234.

Gniewosz, B., Eccles, J. S. i Noack, P. (2011). Secondary school transition and the use of different sources of information for the construction of the academic self-concept. Social Development, 3(21), 537-557.

Gniewosz, B., Eccles, J. S. i Noack, P. (2015). Early adolescents' development of academic self-concept and intrinsic task value: The role of contextual feedback. Journal of Research on Adolescence, 25(3), 459-473.

Gniewosz, B. i Noack, P. (2012). The role of between-parent values agreement in parent-tochild transmission of academic values. Journal of Adolescence, 35(4), 809-821.

Gniewosz, B. i Watt, H. M. (2017). Adolescent-perceived parent and teacher overestimation of mathematics ability: Developmental implications for students' mathematics task values. Developmental Psychology, 53(7), 1371-1383.

Gonzalez-DeHass, A. R., Willems, P. P. i Doan Holbein, M. F. (2005). Examining the relationship between parental involvement and student motivation. Educational Psychology Review, 17, 99-123.

Goodnow, J. J. (1990). The socialization of cognition: What's involved? U J. W. Stigler, R. A. Shweder i G. Herdt (Ur.), Cultural psychology: Essays on comparative human development (str. 259-280). New York: Cambridge University Press.

Gorard, S. i See, B. H. (2009). The impact of socio-economic status on participation and attainment in science. Studies in Science Education, 45(1), 93-129.

Green, M. (2007). Science and Engineering Degrees: 1966-2004 (NSF 07-307). Arlington, VA: National Science Foundation.

Green, C. L., Walker, J. M. T., Hoover-Dempsey, K. V. i Sandler, H. M. (2007). Parents' motivations for involvement in children's education: An empirical test of a theoretical model of parental involvement. Journal of Educational Psychology, 99(3), 532-544. 
Greene, B. A., DeBacker, T. K., Ravindran, B. i Krows, A. J. (1999). Goals, values, and beliefs as predictors of achievement and effort in high school mathematics classes. Sex Roles, 40(5), 421-458.

Grolnick, W. S., Benjet, C., Kurowski, C. O. i Apostoleris, N. H. (1997). Predictors of parental involvement in children's schooling. Journal of Educational Psychology, 89(3), 538-548.

Grolnick, W. S. i Pomerantz, E. M. (2009). Issues and challenges in studying parental control: Toward a new conceptualization. Child Development Perspectives, 3(3), 165-170.

Grolnick, W. S., Raftery-Helmer, J. N., Flamm, E. S., Marbell, K. N. i Cardemil, E. V. (2015). Parental provision of academic structure and the transition to middle school. Journal of Research on Adolescence, 25(4), 668-684.

Grolnick, W. S. i Ryan, R. M. (1989). Parent styles associated with children's self-regulation and competence in schools. Journal of Educational Psychology, 81(2), 143-154.

Grolnick, W. S., Ryan, R. M. i Deci, E. L. (1991). Inner resources for school achievement: Motivational mediators of children's perceptions of their parents. Journal of Educational Psychology, 83(4), 508-517.

Grolnick, W. S. i Slowiaczek, M. L. (1994). Parents' involvement in children's schooling: A multidimensional conceptualization and motivational model. Child Development, 65(1), 237-252.

Gunzler, D., Chen, T., Wu, P. i Zhang, H. (2013). Introduction to mediation analysis with structural equation modeling. Shanghai Archives of Psychiatry, 25(6), 390-394.

Guo, J., Marsh, H. W., Parker, P. D., Dicke, T. i Van Zanden, B. (2019). Countries, parental occupation, and girls' interest in science. Lancet, 393, e6-e8.

Guo, J., Nagengast, B., Marsh, H. W., Kelava, A., Gaspard, H., Brandt, H., . . . Trautwein, U. (2016). Probing the unique contributions of self-concept, task values, and their interactions using multiple value facets and multiple academic outcomes. AERA Open, 2(1), 1-20.

Guo, J., Parker, P. D., Marsh, H. W. i Morin, A. J. (2015). Achievement, motivation, and educational choices: A longitudinal study of expectancy and value using a multiplicative perspective. Developmental Psychology, 51(8), 1163-1176.

Häfner, I., Hulleman, C. S., Rozek, C. S., Hyde, J. S., Harackiewicz, J. M., Nagengast, B. i Trautwein, U. (2016, travanj). STEM motivation and course-taking: Bidirectional relationships between parents and adolescents from middle school to college. Rad prezentiran na Annual Meeting of the American Educational Research Association (AERA) 2016. Washington D.C., Sjedinjene Američke Države.

Hair, J. F., Black, W. C., Babin, B. J. i Anderson, R. E. (2010) Multivariate Data Analysis: 7th Edition. New York: Pearson, 
Halle, T., Kurtz-Costes, B. i Mahoney, J. (1997). Family influences on school achievement in low-income, African American children. Journal of Educational Psychology, 89(3), 527-537.

Harackiewicz, J. M., Rozek, C. S., Hulleman, C. S. i Hyde, J. S. (2012). Helping parents to motivate adolescents in mathematics and science: An experimental test of a utility-value intervention. Psychological Science, 23(8), 899-906.

Hayduk, L. A. i Littvay, L. (2012). Should researchers use single indicators, best indicators, or multiple indicators in structural equation models?. BMC Medical Research Methodology, 12(1), 159.

Heller, K. A. i Ziegler, A. (1996). Gender differences in mathematics and the sciences: Can attributional retraining improve the performance of gifted females? Gifted Child Quarterly, 40(4), 200-210.

Hemphill, F. C. i Vanneman, A. (2011). Achievement gaps: How Hispanic and White students in public schools perform in mathematics and reading on the National Assessment of Educational Progress (NCES 2011-459). Washington, DC: National Center for Education Statistics, Institute of Education Sciences, U.S. Department of Education.

Hess, R. D., Holloway, S. D., Dickson, W. P. i Price, G. G. (1984). Maternal variables as predictors of children's school readiness and later achievement in vocabulary and mathematics in sixth grade. Child Development, 55(5), 1902-1912.

Hill, S. T. i Green, M. M. (2007). Science and engineering degrees, by racelethnicity of recipients: 1995-2004. Arlington, Va.: National Science Foundation.

Hill, N. E. i Tyson, D. F. (2009). Parental involvement in middle school: a meta-analytic assessment of the strategies that promote achievement. Developmental Psychology, 45(3), 740-763.

Holmes, K., Gore, J., Smith, M. i Lloyd, A. (2018). An integrated analysis of school students' aspirations for STEM careers: Which student and school factors are most predictive?. International Journal of Science and Mathematics Education, 16(4), 655-675.

Honey, M., Pearson, G. i Schweingruber, A. (2014). STEM integration in K-12 education: status, prospects, and an agenda for research. Washington: National Academies Press.

Hoogerheide, V., van Wermeskerken, M., Loyens, S. M. i van Gog, T. (2016). Learning from video modeling examples: Content kept equal, adults are more effective models than peers. Learning and Instruction, 44, 22-30.

Hoover-Dempsey, K. V. i Sandler, H. M. (1997). Why do parents become involved in their children's education? Review of Educational Research, 67(1), 3-42.

Hoover-Dempsey, K. V., Walker, J. M., Sandler, H. M., Whetsel, D., Green, C. L., Wilkins, A. S. i Closson, K. (2005). Why do parents become involved? Research findings and implications. The Elementary School Journal, 106(2), 105-130. 
Hsu, H. Y. i Acosta, S. (2011, travanj). The role of parents of adolescents' scientific literacy in Hong Kong: Exploring the transmission of general value of science using PISA 2006. Rad prezentiran na Meeting of American Educational Research Association Annual Conference, New Orleans, Sjedinjene Američke Države.

Hu, L. T. i Bentler, P. M. (1999). Cutoff criteria for fit indexes in covariance structure analysis: Conventional criteria versus new alternatives. Structural Equation Modeling: A Multidisciplinary Journal, 6(1), 1-55.

Huang, H. i Liang, G. (2016). Parental cultural capital and student school performance in mathematics and science across nations. The Journal of Educational Research, 109(3), 286-295.

Hulleman, C. S., Godes, O., Hendricks, B. L. i Harackiewicz, J. M. (2010). Enhancing interest and performance with a utility value intervention. Journal of Educational Psychology, 102(4), 880-895.

Hyde, J. S., Canning, E. A., Rozek, C. S., Clarke, E., Hulleman, C. S. i Harackiewicz, J. M. (2017). The role of mothers' communication in promoting motivation for math and science course-taking in high school. Journal of Research on Adolescence, 27(1), 49-64.

Ing, M. (2014). Gender differences in the influence of early perceived parental support on student mathematics and science achievement and STEM career attainment. International Journal of Science and Mathematics Education, 12(5), 1221-1239.

Jacobs, J. E. (1991). Influence of gender stereotypes on parent and child mathematics attitudes. Journal of Educational Psychology, 83(4), 518-527.

Jacobs, J. E. i Bleeker, M. M. (2004). Girls' and boys' developing interests in math and science: Do parents matter? New Directions for Child and Adolescent Development, $106,5-21$.

Jacobs, J. E., Davis-Kean, P., Bleeker, M., Eccles, J. S. i Malanchuk, O. (2005). I can, but I don't want to. The impact of parents, interests, and activities on gender differences in math. U A. Gallagher i J. Kaufman (Ur.), Gender difference in mathematics (str. 246263). New York: Cambridge University Press.

Jacobs, J. E. i Eccles, J. S. (1992). The impact of mothers' gender-role stereotypic beliefs on mothers' and children's ability perceptions. Journal of Personality and Social Psychology, 63(6), 932-944.

Jacobs, J. E. i Eccles, J. S. (2000). Parents, task values, and real-life achievement-related choices. U C. Sansone i J. M. Harackiewicz (Ur.), Intrinsic and extrinsic motivation: The search for optimal motivation and performance (str. 405-438). San Diego: Academic Press.

Jacobs, J. E., Lanza, S., Osgood, D. W., Eccles, J. S. i Wigfield, A. (2002). Changes in children's self-competence and values: Gender and domain differences across grades one through twelve. Child Development, 73(2), 509-527. 
Jansen, M., Scherer, R. i Schroeders, U. (2015). Students' self-concept and self-efficacy in the sciences: Differential relations to antecedents and educational outcomes. Contemporary Educational Psychology, 41, 13-24.

Jodl, K. M., Michael, A., Malanchuk, O., Eccles, J. S. i Sameroff, A. (2001). Parents' Roles in Shaping Early Adolescents' Occupational Aspirations. Child Development, 72(4), 124765 .

Johansson, L. (2009). Mathematics, science \& technology education report. Brussels, Belgium: European Round Table of Industrials.

Johnson, C. C. (2013). Conceptualizing integrated STEM education. School Science and Mathematics, 113(8), 367-368.

Jokić, B. i Ristić Dedić, Z. (2014). Postati student u Hrvatskoj. Zagreb: Agencija za znanost i visoko obrazovanje.

Joreskog, K. G. i Sorbom, D. (1989). LISREL 7: User's reference guide. Mooresville, IN: Scientific Software.

Juang, L. P. i Silbereisen, R. K. (2002). The relationship between adolescent academic capability beliefs, parenting and school grades. Journal of Adolescence, 25(1), 3-18.

Jugović, I., Baranović, B. i Marušić, I. (2012). Uloga rodnih stereotipa i motivacije u objašnjenju matematičkog uspjeha i straha od matematike. Suvremena Psihologija, 15(1), 65-78.

Karbach, J., Gottschling, J., Spengler, M., Hegewald, K. i Spinath, F. M. (2013). Parental involvement and general cognitive ability as predictors of domain-specific academic achievement in early adolescence. Learning and Instruction, 23, 43-51.

Kelloway, E. K. (1998). Using LISREL for structural equation modeling: A researcher's guide. Thousand Oaks, CA: Sage.

Kim, J. S. (2011, studeni). New national curriculum of technology education in Korea. Rad prezentiran na 2011 International conference on technology education in the PacificRim Countries, Nagoya, Japan.

Kline, R. B. (2005). Principles and practice of structural equation modeling (2nd ed.). New York: Guilford.

Kline, R. B. (2015). Principles and practice of structural equation modeling. New York: Guilford publications.

Korkmaz, S., Goksuluk, D., Zararsiz, G. i Korkmaz, M. S. (2019). Package 'MVN'. Preuzeto s https://cran.r-project.org/web/packages/MVN/MVN.pdf

Kuenzi, J., Matthews, C. i Mangan, B. (2006). Science, technology, engineering, and mathematics (STEM) education issues and legislative options. Congressional research report. Washington, DC: Congressional Research Service. 
Kung, H. Y. i Lee, C. Y. (2016). Multidimensionality of parental involvement and children's mathematics achievement in Taiwan: Mediating effect of math self-efficacy. Learning and Individual Differences, 47, 266-273.

Larson, R. W. i Verma, S. (1999). How children and adolescents spend time across the world: Work, play, and developmental opportunities. Psychological Bulletin, 125(6), 701-736.

Lauermann, F., Tsai, Y. M. i Eccles, J. S. (2017). Math-related career aspirations and choices within Eccles et al.'s expectancy-value theory of achievement-related behaviors. Developmental Psychology, 53(8), 1540-1559.

Lazarides, R., Harackiewicz, J., Pesu, L. i Viljaranta, J. (2015). The role of parents in students' motivational beliefs and values. U C. M. Rubie-Davies, J. M. Stephens i P. Watson (Ur.), The social psychology of the classroom international handbook (str. 5366). London: Routledge.

Lazarides, R. i Ittel, A. (2013). Mathematics interest and achievement: What role do perceived parent and teacher support play? A longitudinal analysis. International Journal of Gender, Science and Technology, 5(3), 207-231.

Lazarides, R., Rubach, C. i Ittel, A. (2017). Adolescents' perceptions of socializers' beliefs, career-related conversations, and motivation in mathematics. Developmental Psychology, 53(3), 525-539.

Lee, J. S. i Bowen, N. K. (2006). Parent involvement, cultural capital, and the achievement gap among elementary school children. American Educational Research Journal, 43(2), 193-218.

LeFevre, J. A., Skwarchuk, S. L., Smith-Chant, B. L., Fast, L., Kamawar, D. i Bisanz, J. (2009). Home numeracy experiences and children's math performance in the early school years. Canadian Journal of Behavioural Science, 41(2), 55-66.

Levine, S. C., Suriyakham, L. W., Rowe, M. L., Huttenlocher, J. i Gunderson, E. A. (2010). What counts in the development of young children's number knowledge? Developmental Psychology, 46(5), 1309-1319.

Little, T. D. (2013). Longitudinal structural equation modeling: Methodology in social sciences. New York: Guilford Press.

Little, T. D., Jorgensen, T. D., Lang, K. M. i Moore, E. W. G. (2014). On the joys of missing data. Journal of Pediatric Psychology, 39(2), 151-162.

Long, H. i Pang, W. (2016). Family socioeconomic status, parental expectations, and adolescents' academic achievements: A case of China. Educational Research and Evaluation, 22(5-6), 283-304.

Lummis, M. i Stevenson, H. W. (1990). Gender differences in beliefs and achievement: A cross-cultural study. Developmental Psychology, 26(2), 254-263. 
Lykkegaard, E. i Ulriksen, L. (2016). Choices and changes: Eccles' Expectancy-Value model and upper-secondary school students' longitudinal reflections about their choice of a STEM education. International Journal of Science Education, 38(5), 701-724.

Lyons, T. i Quinn, F. (2010). Choosing science. Understanding the declines in senior high school science enrolments. Armidale, NSW: University of New England.

Maassen, G. H. i Bakker, A. B. (2001). Suppressor variables in path models: Definitions and interpretations. Sociological Methods \& Research, 30(2), 241-270.

Mac Iver, D. J., Stipek, D. J. i Daniels, D. H. (1991). Explaining within-semester changes in student effort in junior high school and senior high school courses. Journal of Educational Psychology, 83(2), 201-211.

Maloney, E. A. i Beilock, S. L. (2012). Math anxiety: Who has it, why it develops, and how to guard against it. Trends in Cognitive Sciences, 16(8), 404-406.

Mann, A. i DiPrete, T. A. (2013). Trends in gender segregation in the choice of science and engineering majors. Social Science Research, 42(6), 1519-1541.

Marjoribanks, K. (2002). Family and school capital: Towards a context theory of students' school outcomes. Dordrecht: Kluwer Academic

Marsh, H. W. (1990). A multidimensional, hierarchical self-concept: Theoretical and empirical justification. Educational Psychology Review, 2, 77-172.

Marsh, H. W., Köller, O., Trautwein, U., Lüdtke, O. i Baumert, J. (2005). Academic selfconcept, interest, grades, and standardized test scores: Reciprocal effects models of causal ordering. Child Development, 76(2), 397-416.

Maxwell, S. E. i Cole, D. A. (2007). Bias in cross-sectional analyses of longitudinal mediation. Psychological Methods, 12(1), 23-44.

Meece, J. L., Wigfield, A. i Eccles, J. S. (1990). Predictors of math anxiety and its influence on young adolescents' course enrollment intentions and performance in mathematics. Journal of Educational Psychology, 82(1), 60-70.

Meer, J. (2007). Evidence on the returns to secondary vocational education. Economics of Education Review, 26(5), 559-573.

Millsap, R. E. (2011). Statistical approaches to measurement invariance. New York: Routledge.

Ministarstvo znanosti i obrazovanja [MZO]. (1994). Nastavni program za gimnazije. Preuzeto s http://dokumenti.ncvvo.hr/Nastavni_plan/gimnazije/obvezni/nastavni-program.pdf

Ministarstvo znanosti i obrazovanja [MZO]. (2012). Pravilnik o polaganju državne mature. Preuzeto s https://mzo.hr/sites/default/files/dokumenti/2019/Obrazovanje/Drzavnamatura/pravilnik_o_polaganju_drzavne_mature_nn_01-13.pdf 
Ministarstvo znanosti i obrazovanja [MZO]. (2013). Pravilnik o elementima i kriterijima za izbor kandidata za upis u I. razred srednje škole. Preuzeto s https://narodnenovine.nn.hr/clanci/sluzbeni/2015_05_49_981.html

Ministarstvo znanosti i obrazovanja [MZO]. (2017). Nacionalni kurikulum za osnovnoškolski odgoj i obrazovanje. Preuzeto s https://mzo.gov.hr/dokumenti/10

Ministarstvo znanosti i obrazovanja [MZO]. (2018a). Nacionalni kurikulum nastavnoga predmeta matematika. Preuzeto s

https://mzo.hr/sites/default/files/dokumenti/2018/OBRAZOVANJE/Nacionalnikurikulumi/matematika_nakon_recenzije.pdf

Ministarstvo znanosti i obrazovanja [MZO]. (2018b). Odluka o donošenju kurikuluma za nastavni predmet Informatike za osnovne škole i gimnazije u Republici Hrvatskoj. Preuzeto s https://narodne-novine.nn.hr/clanci/sluzbeni/2018_03_22_436.html

Ministarstvo znanosti i obrazovanja [MZO]. (2017b). Pravilnik o pedagoškoj dokumentaciji i evidenciji te javnim ispravama u školskim ustanovama. Preuzeto s https://narodnenovine.nn.hr/clanci/sluzbeni/2017_05_47_1108.html

Moakler Jr, M. W. i Kim, M. M. (2014). College major choice in STEM: Revisiting confidence and demographic factors. The Career Development Quarterly, 62(2), 128142 .

Möller, J., Zimmermann, F. i Köller, O. (2014). The reciprocal internal/external frame of reference model using grades and test scores. British Journal of Educational Psychology, 84(4), 591-611.

Moon, B., Brown, S. i Ben-Peretz, M. (2000). Routledge international companion to education. London: Taylor and Francis Books.

Morgan, P. L., Farkas, G., Hillemeier, M. M. i Maczuga, S. (2016). Science achievement gaps begin very early, persist, and are largely explained by modifiable factors. Educational Researcher, 45(1), 18-35.

Muller, C. (1998). Gender differences in parental involvement and adolescents' mathematics achievement. Sociology of Education, 71(4), 336-356.

Murayama, K., Pekrun, R., Suzuki, M., Marsh, H. W. i Lichtenfeld, S. (2016). Don't aim too high for your kids: Parental overaspiration undermines students' learning in mathematics. Journal of Personality and Social Psychology, 111(5), 766-779.

Musu-Gillette, L. E., Wigfield, A., Harring, J. R. i Eccles, J. S. (2015). Trajectories of change in students' self-concepts of ability and values in math and college major choice. Educational Research and Evaluation, 21(4), 343-370.

Nacionalni centar za vanjsko vrednovanje obrazovanja [NCVVO]. (2015). Nastavni planovi i programi za gimnazije i strukovne škole. Preuzeto s https://www.ncvvo.hr/nastavniplanovi-i-programi-za-gimnazije-i-strukovne-skole/ 
Nacionalni informacijski sustav prijave na visoka učilišta. (2019). Studijski programi. Preuzeto s https://www.postani-student.hr/Ucilista/Nositelji.aspx

Nagengast, B., Marsh, H. W., Scalas, L. F., Xu, M. K., Hau, K. T. i Trautwein, U. (2011). Who took the " $x$ " out of expectancy-value theory? A psychological mystery, a substantive methodological synergy, and a cross-national generalization. Psychological Science, 22(8), 1058-1066.

National Academy of Engineering and National Research Council. (2014). STEM integration in K-12 education: Status, prospects, and an agenda for research. Washington: National Academies Press.

National Center for Education Statistics [NCES]. (2012). The nation's report card: Science 2011 (NCES 2012-465). Washington, DC: Institute of Education Sciences, U.S. Department of Education.

National Governors Association [NGA]. (2007). Building a science, technology, engineering and math agenda. Washington, DC: NGA.

National Research Council [NRC]. (2009). Engineering in K-12 education: Understanding the status and improving the prospects. Washington, DC: The National Academies Press.

National Research Council [NRC]. (2011). Successful K-12 STEM education: Identifying effective approaches in science, technology, engineering, and mathematics. Washington, DC: National Academy Press.

National Research Council [NRC]. (2015). Identifying and supporting productive programs in out-of-school settings. Washington, DC: The National Academies Press.

National Science Board [NSB]. (2010). Science and engineering indicators 2010. Arlington, VA: National Science Foundation.

National Science Foundation [NSF]. (2009). Women, minorities, and persons with disabilities in science and engineering. Arlington: National Science Foundation.

Neuenschwander, M. P., Vida, M., Garrett, J. L. i Eccles, J. S. (2007). Parents' expectations and students' achievement in two western nations. International Journal of Behavioral Development, 31(6), 594-602.

Neumann, K., Kauertz, A. i Fischer, H. E. (2012). Quality of instruction in science education. U B. J. Fraser, K. Tobin i C. J. McRobbie (Ur.), Second international handbook on science education (str. 247-258). New York: Springer.

Nugent, G., Barker, B., Welch, G., Grandgenett, N., Wu, C. i Nelson, C. (2015). A model of factors contributing to STEM learning and career orientation. International Journal of Science Education, 37(7), 1067-1088.

OECD. (2007). PISA 2006 Science competencies for tomorrow's world, Volume 1: Analysis. Paris: OECD Publishing. 
OECD. (2008). Encouraging students interest in science and technology studies. Paris: OECD Publishing.

OECD. (2012). Closing the gender gap. Act now. Paris: OECD Publishing.

Paa, H. K. i McWhirter, E. H. (2000). Perceived influences on high school students' current career expectations. Career Development Quarterly, 49(1), 29-44.

Pajares, F. (1996). Self-efficacy beliefs and mathematical problem-solving of gifted students. Contemporary Educational Psychology, 21(4), 325-344.

Pajares, F. i Miller, M. D. (1994). Role of self-efficacy and self-concept beliefs in mathematical problem solving: A path analysis. Journal of Educational Psychology, 86(2), 193-203.

Pajares, F. i Schunk, D. H. (2005). Self-efficacy and self-concept beliefs: Jointly contributing to the quality of human life. U H. Marsh, R. Craven i D. McInerney (Ur.), International advances in self-research (Vol. 2, str. 95-121). Greenwich, CT: Information Age.

Pan, Y., Yang, Q., Li, Y., Liu, L. i Liu, S. (2018). Effects of family socioeconomic status on home math activities in urban China: The role of parental beliefs. Children and Youth Services Review, 93, 60-68.

Parcel, T. i Menaghan, E. (1990). Maternal working conditions and children's verbal facility: Studying the intergenerational transmission of inequality from mothers to young children. Social Psychology Quarterly, 53(2), 132-147.

Patall, E. A., Cooper, H. i Robinson, J. C. (2008). Parent involvement in homework: A research synthesis. Review of Educational Research, 78(4), 1039-1101.

Paulson, S. E. i Sputa, C. L. (1996). Patterns of parenting during adolescence: Perceptions of adolescents and parents. Adolescence, 31(122), 369-381.

Perera, L. D., Bomhoff, E. J. i Lee, H. Y. (2014). Parents' attitudes towards science and their children's science achievement. International Journal of Science Education, 36(18), 3021-3041.

Pesu, L., Aunola, K., Viljaranta, J., Hirvonen, R. i Kiuru, N. (2018). The role of mothers' beliefs in students' self-concept of ability development. Learning and Individual Differences, 65, 230-240.

Pesu, L., Aunola, K., Viljaranta, J. i Nurmi, J. E. (2016). The development of adolescents' self-concept of ability through grades 7-9 and the role of parental beliefs. Frontline Learning Research, 4(3), 92-109.

Phillips, D. A. (1987). Socialization of perceived academic competence among highly competent children. Child Development, 58(5), 1308-1320.

Pomerantz, E. M. i Eaton, M. M. (2001). Maternal intrusive support in the academic context: Transactional socialization processes. Developmental Psychology, 37(2), 174-186. 
Pomerantz, E. M. i Grolnick, W. S. (2009). Toward a clear and inclusive conceptualization of parental control: Reply to the commentaries. Child Development Perspectives, 3(3), 176-177.

Pomerantz, E. M. i Grolnick, W. S. (2017). The role of parenting in children's motivation and competence: What underlies facilitative parenting?. U A. J. Elliot., C. Dweck. i D. Yeager (Ur.), Handbook of competence and motivation (str. 566-585). New York: Guilford Press.

Pomerantz, E. M., Moorman, E. A. i Litwack, S. D. (2007). The how, whom, and why of parents' involvement in children's schooling: More is not necessarily better. Review of Educational Research, 77(3), 373-410.

President's Council of Advisors on Science and Technology [PCAST]. (2012). Engage to excel: Producing one million additional college graduates with degrees in science, technology, engineering, and mathematics. Washington, DC: Executive Office of the President. Preuzeto s http://files.eric.ed.gov/fulltext/ED541511.pdf

Pulos, S. i Fisher, S. (1993). Children's interest in computers: A social cognitive perspective. U J. R. Schement (Ur.), Between communication and information (str. 269-291). New Brunswick: Transaction.

Radloff, J. i Guzey, S. (2016). Investigating preservice STEM teacher conceptions of STEM education. Journal of Science Education and Technology, 25(5), 759-774.

Ramsey, K. i Baethe, B. (2013). The keys to future STEM careers: Basic skills, critical thinking, and ethics. Delta Kappa Gamma Bulletin, 80(1), 26-33.

Rayman, P. i Brett, B. (1995). Women science majors: What makes a difference in persistence after graduation? Journal of Higher Education, 66(4), 388-414.

Renninger, K. A., Hidi, S. i Krapp, A. (1992). The role of interest in learning and development. Hillsdale, NJ: Erlbaum.

Reynolds, A. J. (1991). The middle schooling process: Influences on science and mathematics achievement from the longitudinal study of American youth. Adolescence, 26(101), 132-157.

Ritz, J. M. i Fan, S. C. (2015). STEM and technology education: International state-of-the-art. International Journal of Technology and Design Education, 25(4), 429-451.

Roberts, A. (2013). STEM is here. Now what?. Technology \& Engineering Teacher, 73(1), 22-27.

Robinson, K. (2014). The broken compass. Cambridge, MA: Harvard University Press.

Rogers, W. M. (2002). Theoretical and mathematical constraints of interactive regression models. Organizational Research Methods, 5(3), 212-230.

Rosseel, Y. (2012a). Lavaan: An R package for structural equation modeling and more. Version 0.5-12 (BETA). Journal of Statistical Software, 48(2), 1-36. 
Rosseel, Y. (2012b). lavaan: a brief user's guide. Preuzeto s https://users.ugent.be/ yrosseel/lavaan/lavaan2.pdf

Rosseel, Y. (2019). The lavaan tutorial. Preuzeto s http://lavaan.ugent.be/tutorial/tutorial.pdf

Rovan, D., Pavlin-Bernardić, N. i Vlahović-Štetić, V. (2013). Struktura motivacijskih uvjerenja u matematici i njihova povezanost s obrazovnim ishodima. Društvena istraživanja, 22(3), 475-495.

Rozek, C. S., Hyde, J. S., Svoboda, R. C., Hulleman, C. S. i Harackiewicz, J. M. (2015). Gender differences in the effects of a utility-value intervention to help parents motivate adolescents in mathematics and science. Journal of Educational Psychology, 107(1), 195206.

Ruble, D. N. (1994). A phase model of transitions: Cognitive and motivational consequences. Advances in Experimental Social Psychology, 26, 163-214.

Sadler, P. M., Sonnert, G., Hazari, Z. i Tai, R. (2012). Stability and volatility of STEM career interest in high school: A gender study. Science Education, 96(3), 411-427.

Sameroff, A. (2009). The transactional model of development: How children and contexts shape each other. Washington, DC: American Psychological Association.

Satorra, A. i Bentler, P. M. (2001). A scaled difference chi-square test statistic for moment structure analysis. Psychometrika, 66(4), 507-514.

Savalei, V. i Falk, C. F. (2014). Robust two-stage approach outperforms robust full information maximum likelihood with incomplete nonnormal data. Structural Equation Modeling: A Multidisciplinary Journal, 21(2), 280-302.

Schneider, B. i Coleman, J. S. (1993). Parents, their children, and schools. Boulder, CO: Westview Press.

Schreiber, J. B., Nora, A., Stage, F. K., Barlow, E. A. i King, J. (2006). Reporting structural equation modeling and confirmatory factor analysis results: A review. The Journal of Educational Research, 99(6), 323-338.

Seginer, R. (2006). Parents' educational involvement: A developmental ecology perspective. Parenting: Science and Practice, 6(1), 1-48.

Sha, L., Schunn, C., Bathgate, M. i Ben-Eliyahu, A. (2016). Families support their children's success in science learning by influencing interest and self-efficacy. Journal of Research in Science Teaching, 53(3), 450-472.

Shapiro, H., Ostergaard, S. F. i Hougaard, K. F. (2015). Does the EU need more STEM graduates?: Final report. Luxembourg: Publications Office of the European Union.

Shin, T., Davison, M. L., Long, J. D., Chan, C. K. i Heistad, D. (2013). Exploring gains in reading and mathematics achievement among regular and exceptional students using growth curve modeling. Learning and Individual Differences, 23, 92-100. 
Silinskas, G. i Kikas, E. (2019). Parental involvement in math homework: Links to children's performance and motivation. Scandinavian Journal of Educational Research, 63(1), 17 37.

Silinskas, G., Kiuru, N., Aunola, K., Lerkkanen, M. K. i Nurmi, J. E. (2015). The developmental dynamics of children's academic performance and mothers' homeworkrelated affect and practices. Developmental Psychology, 51(4), 419-433.

Silinskas, G., Leppänen, U., Aunola, K., Parrila, R. i Nurmi, J. E. (2010). Predictors of mothers' and fathers' teaching of reading and mathematics during kindergarten and grade 1. Learning and Instruction, 20(1), 61-71.

Silk, J. S., Morris, A. S., Kanaya, T. i Steinberg, L. (2003). Psychological control and autonomy granting: Opposite ends of a continuum or distinct constructs? Journal of Research on Adolescence, 13(1), 113-128.

Simpkins, S. D., Davis-Kean, P. E. i Eccles, J. S. (2005). Parents' socializing behavior and children's participation in math, science, and computer out-of-school activities. Applied Developmental Science, 9(1), 14-30.

Simpkins, S. D., Davis-Kean, P. E. i Eccles, J. S. (2006). Math and science motivation: A longitudinal examination of links between choices and beliefs. Developmental Psychology, 42(1), 70-83.

Simpkins, S., Estrella, G., Gaskin, E. i Kloberdanz, E. (2018). Latino parents' science beliefs and support of high school students' motivational beliefs: Do the relations vary across gender and familism values?. Social Psychology of Education, 21(5), 1203-1224.

Simpkins, S. D., Fredricks, J. A. i Eccles, J. S. (2012). Charting the Eccles' expectancy-value model from mothers' beliefs in childhood to youths' activities in adolescence. Developmental Psychology, 48(4), 1019-1032.

Simpkins, S. D., Fredricks, J. i Eccles, J. S. (2015a). Families, schools, and developing achievement-related motivations and engagement. U J. E. Grusec i P. D. Hastings, (Ur.), Handbook of socialization theory and research - Second edition (str. 614-636). New York: Guilford Press.

Simpkins, S. D., Fredricks, J. i Eccles, J. S. (2015b). The role of parents in the ontogeny of achievement-related motivation and behavioral choices. Monographs of the Society for Research in Child Development, 80(2), 1-169.

Simpkins, S. D., Price, C. D. i Garcia, K. (2015c). Parental support and high school students' motivation in biology, chemistry, and physics: Understanding differences among Latino and Caucasian boys and girls. Journal of Research in Science Teaching, 52(10), 13861407.

Singh, K., Bickley, P. G., Keith, T. Z., Keith, P. B., Trivette, P. i Anderson, E. (1995). The effects of four components of parental involvement on eighth grade student 
achievement: structural analysis of NELS-88 data. School Psychology Review, 24(2), 299-317.

Singh, K., Granville, M. i Dika, S. (2002). Mathematics and science achievement: Effects of motivation, interest, and academic engagement. The Journal of Educational Research, 95(6), 323-332.

Sirin, S. R. (2005). Socioeconomic status and academic achievement: A meta-analytic review of research. Review of Educational Research, 75(3), 417-453.

Skinner, E. A., Johnson, S. i Snyder, T. (2005). Six dimensions of parenting: A motivational model. Parenting, 5(2), 175-235.

Smith, E. (2011). Women into science and engineering? Gendered participation in higher education STEM subjects. British Educational Research Journal, 37(6), 993-1014.

Smith, M. K. i Knight, J. K. (2012). Using the genetics concept assessment to document presistent conceptual difficulties in undergraduate genetics courses. Genetics, 191(1), 21-32.

Spera, C. (2005). A review of the relationship among parenting practices, parenting styles, and adolescent school achievement. Educational Psychology Review, 17, 125-146.

Spera, C. (2006). Adolescents' perceptions of parental goals, practices, and styles in relation to their motivation and achievement. The Journal of Early Adolescence, 26(4), 456-490.

Spinath, B., Spinath, F. M., Harlaar, N. i Plomin, R. (2006). Predicting school achievement from general cognitive ability, self-perceived ability, and intrinsic value. Intelligence, 34(4), 363-374.

Starkey, P. i Klein, A. (2008). Sociocultural influences on young children's mathematical knowledge. U O. N. Saracho i B. Spodek (Ur.), Contemporary perspectives on mathematics in early childhood education (str. 253-276). Charlotte, NC: Information Age Publishing.

Stevenson, H. i Newman, R. (1986). Long-term prediction of achievement and attitudes in mathematics and reading. Child Development, 57(3), 646-659.

Su, Y., Doerr, H. S., Johnson, W., Shi, J. i Spinath, F. M. (2015). The role of parental control in predicting school achievement independent of intelligence. Learning and Individual Differences, 37, 203-209.

Su, R. i Rounds, J. (2015). All STEM fields are not created equal: People and things interests explain gender disparities across STEM fields. Frontiers in Psychology, 6(189), 1-20.

Svoboda, R. C., Rozek, C. S., Hyde, J. S., Harackiewicz, J. M. i Destin, M. (2016). Understanding the relationship between parental education and STEM course taking through identity-based and expectancy-value theories of motivation. AERA Open, 2(3), $1-13$. 
Szechter, L. E. i Carey, E. J. (2009). Gravitating toward science: Parent-child interactions at a gravitational-wave observatory. Science Education, 93(5), 846-858.

Šimunović, M. i Babarović, T. (u tisku). The role of parental socializing behaviors in two domains of student STEM career interest. Research in Science Education.

Tabachnick, B. G. i Fidell, L. S. (2013). Using multivariate statistics (6th edition). New Jersey: Pearson Education Inc.

Tai, R. H., Liu, C. Q., Maltese, A. V. i Fan, X. (2006). Planning early for careers in science. Science, 312(5777), 1143-1144.

Taskinen, P. H., Dietrich, J. i Kracke, B. (2016). The role of parental values and childspecific expectations in the science motivation and achievement of adolescent girls and boys. International Journal of Gender, Science and Technology, 8(1), 104-123.

Tenenbaum, H. T. i Leaper, C. (2003). Parent-child conversations about science: The socialization of gender inequities? Developmental Psychology, 39(1), 34-37.

Thomas, J. A. i Strunk, K. K. (2017). Expectancy-value and children's science achievement: Parents matter. Journal of Research in Science Teaching, 54(6), 693-712.

Tiedemann, J. (2000). Parents' gender stereotypes and teachers' beliefs as predictors of children's concept of their mathematical ability in elementary school. Journal of Educational Psychology, 92(1), 144-151.

Tobias, S. (1994). Interest, prior knowledge, and learning. Review of Educational Research, 64(1), 37-54.

Trautwein, U., Marsh, H. W., Nagengast, B., Lüdtke, O., Nagy, G. i Jonkmann, K. (2012). Probing for the multiplicative term in modern expectancy-value theory: A latent interaction modeling study. Journal of Educational Psychology, 104(3), 763-777.

Tripney, J., Newman, M., Bangpan, M., Niza, C., Mackintosh, M. i Sinclair, J. (2010). Factors influencing young people (aged 14-19) in Education about STEM subject choices: A systematic review of the UK literature. London: Evidence for Policy and Practice Information and Co-ordinating Centre.

Tsupros, N., Kohler, R. i Hallinen, J. (2009). STEM Education in Southwestern Pennsylvania: Report of a project to identify the missing components. Intermediate Unit 1: Center for STEM Education and Leonard Gelfand Center for Service Learning and Outreach, Carnegie Mellon University, Pennsylvania. Preuzeto s https://www.cmu.edu/gelfand/documents/stem-survey-report-cmu-iu1.pdf

Tucker-Drob, E. M., Briley, D. A. i Harden, K. P. (2013). Genetic and environmental influences on cognition across development and context. Current Directions in Psychological Science, 22(5), 349-355. 
Turner, S. L., Steward, J. C. i Lapan, R. T. (2004). Family factors associated with sixth-grade adolescents' math and science career interests. Career Development Quarterly, 53(1), 41-52.

Tyson, W., Lee, R., Borman, K. M. i Hanson, M. A. (2007). Science, technology, engineering, and mathematics (STEM) pathways: High school science and math coursework and postsecondary degree attainment. Journal of Education for Students Placed at Risk, 12(3), 243-270.

Ullman, J. B. i Bentler, P. M. (2013). Structural equation modeling. U I. B. Weiner (Ur.), Handbook of psychology, Second edition (str. 661-690). New York: John Wiley \& Sons Inc.

VanMeter-Adams, A., Frankenfeld, C. L., Bases, J., Espina, V. i Liotta, L. A. (2014). Students who demonstrate strong talent and interest in STEM are initially attracted to STEM through extracurricular experiences. CBE_Life Sciences Education, 13(4), 687 697.

Vansteenkiste, M., Lens, W. i Deci, E. L. (2006). Intrinsic versus extrinsic goal contents in self-determination theory: Another look at the quality of academic motivation. Educational Psychologist, 41(1), 19-31.

Verdine, B. N., Irwin, C. M., Golinkoff, R. M. i Hirsh-Pasek, K. (2014). Contributions of executive function and spatial skills to preschool mathematics achievement. Journal of Experimental Child Psychology, 126, 37-51.

Viljaranta, J., Lazarides, R., Aunola, K., Räikkönen, E. i Nurmi, J. E. (2015). The different role of mothers' and fathers' beliefs in the development of adolescents' mathematics and literacy task values. Journal of Gender, Science and Technology, 2015(1), 297-317.

Vygotsky, L. S. (1978). Mind in society: The development of higher psychological processes. Cambridge, MA: Harvard University Press.

Walker, J. M., Wilkins, A. S., Dallaire, J. R., Sandler, H. M. i Hoover-Dempsey, K. V. (2005). Parental involvement: Model revision through scale development. The Elementary School Journal, 106(2), 85-104.

Wang, M. T., Eccles, J. S. i Kenny, S. (2013). Not lack of ability but more choice: Individual and gender differences in choice of careers in science, technology, engineering, and mathematics. Psychological Science, 24(5), 770-775.

Watt, H. M. G. (2004). Development of adolescents' self-perceptions, values, and task perceptions according to gender and domain in 7th- through 11th-Grade Australian students. Child Development, 75(5), 1556-1574.

Watt, H. M., Shapka, J. D., Morris, Z. A., Durik, A. M., Keating, D. P. i Eccles, J. S. (2012). Gendered motivational processes affecting high school mathematics participation, educational aspirations, and career plans: A comparison of samples from Australia, Canada, and the United States. Developmental Psychology, 48(6), 1594-1611. 
Weston, R. i Gore Jr, P. A. (2006). A brief guide to structural equation modeling. The Counseling Psychologist, 34(5), 719-751.

Whitaker, M. i Hoover-Dempsey, K. (2013). School influences on parents' role beliefs. The Elementary School Journal, 114(1), 73-99.

Wigfield, A. (1994). Expectancy-value theory of achievement motivation: A developmental perspective. Educational Psychology Review, 6(1), 49-78.

Wigfield, A. i Cambria, J. (2010). Expectancy-value theory: Retrospective and prospective. U T. C. Urdan i S. A. Karabenick (Ur.), The decade ahead: Theoretical perspectives on motivation and achievement (Advances in motivation and achievement, Volume 16) (str. 74-146). Bingley, UK: Emerald Group Publishing Limited.

Wigfield, A. i Eccles, J. S. (1992). The development of achievement task values: A theoretical analysis. Developmental Review, 12, 265-310.

Wigfield, A. i Eccles, J. S. (2000). Expectancy-value theory of achievement motivation. Contemporary Educational Psychology, 25(1), 68-81.

Wigfield, A. i Eccles, J. S. (2002). The development of competence beliefs, expectancies for success, and achievement values from childhood through adolescence. U A. Wigfield i J. S. Eccles (Ur.), Development of achievement motivation (str. 91-120). Dordrecht: Kluwer.

Wigfield, A., Eccles, J. S., Fredricks, J., Simpkins, S., Roeser, R. i Schiefele, U. (2015). Development of achievement motivation and engagement. U R. Lerner, M. Lamb i C. Garcia Coll (Ur.), Handbook of child psychology and developmental science (7th ed., Vol. 3, str. 657-700). New York: John Wiley \& Sons Inc.

Wigfield, A., Eccles, J. S., Schiefele, U., Roeser, R. i Davis-Kean, P. (2006). Development of achievement motivation. U W. Damon \& N. Eisenberg (Ur.), Handbook of child psychology: Vol. 3. Social, emotional, and personality development (6th ed., str. 9331002). New York: Wiley.

Wigfield, A. i Gladstone, J. R. (2019). What does expectancy-value theory have to say about motivation and achievement in times of change and uncertainty?. U E. N. Gonida i M. S. Lemos (Ur.), Motivation in education at a time of global change: Theory, research, and implications for practice (str. 15-32). Bingley, UK: Emerald Publishing Limited.

Wigfield, A., Rosenzweig, E. Q. i Eccles, J. S. (2017). Achievement values: Interactions, interventions, and future directions. U A. J. Elliot, C. S. Dweck i D. S. Yeager (Ur.), Handbook of competence and motivation (str. 116-134). New York: Guilford.

Wigfield, A., Tonks, S. i Lutz Klauda, S. (2009). Expectancy-value theory. U K. R. Wentzel i A. Wigfield (Ur.), Handbook of motivation at school (str. 55-75). New York: Routledge.

Wilder, S. (2013). Effects of parental involvement on academic achievement: A metasynthesis. Educational Review, 66(3), 377-397. 
Xie, Y., Fang, M. i Shauman, K. (2015). STEM education. Annual Review of Sociology, 41, 331-357.

Xie, Y. i Killewald, A. A. (2012). Is American science in decline? Cambridge, MA: Harvard University Press.

Yamamoto, Y. i Holloway, S. D. (2010). Parental expectations and children's academic performance in sociocultural context. Educational Psychology Review, 22(3), 189-214.

Yamamoto, Y., Holloway, S. D. i Suzuki, S. (2016). Parental engagement in children's education: Motivating factors in Japan and the US. School Community Journal, 26(1), 45-66.

Yee, D. K. i Eccles, J. S. (1988). Parent perceptions and attributions for children's math achievement. Sex Roles, 19(5), 317-333.

Young, M. (1998). The curriculum of the future: from the 'new sociology of education' to a critical theory of learning. London: Falmer Press.

Zimmer-Gembeck, M. J. i Collins, W. A. (2006). Autonomy development during Adolescence. U G. R. Adams i M. Berzonsky (Ur.), Blackwell handbook of adolescence (str. 175-204). Malden: Blackwell. 


\section{PRILOZI}

Prilog 1. Upute za školske koordinatore o postupku roditeljskog istraživanja

\section{JOBSTEM PROJEKT}

Provođenje ispitivanja roditelja Upitnikom za roditelje/skrbnike

\section{Upute za koordinatore i razrednike $(\mathbf{m} / \check{\mathbf{z}})$}

Poštovani,

Zahvaljujem se na trudu koji ulažete u organizaciju i provođenje ispitivanja roditelja učenika koji sudjeluju u JOBSTEM projektu. Ukratko, u ispitivanju sudjeluju roditelji učenika osnovnih škola, unutar JOBSTEM projekta, pa tako i roditelji vaših učenika. JOBSTEM upitnik za roditelje popunjava jedan od roditelja učenika 6. i 7. razreda, razrednih odjela koji sudjeluju u JOBSTEM projektu. Roditelji učenika 5. razreda ne sudjeluju ove godine u ispitivanju, već je njihovo ispitivanje predviđeno za sljedeću šk. godinu, kada njihova djeca budu u 6. razredu.

Kako bi ispitivanje u svim školama bilo provedeno istovjetno, izradili smo ove upute. Molimo Vas da ih se tijekom provođenja ispitivanja pridržavate.

\section{A. PODJELA UPITNIKA RAZREDNICIMA:}

1. Školski koordinator će razrednicima 6. i 7. razrednih odjela koji sudjeluju u projektu podijeliti onoliko upitnika koliko ima djece koja sudjeluju u JOBSTEM projektu.

2. Između upitnika za 6. i 7. razreda postoje razlike u sadržaju. Pripazite da roditelji dobiju primjerenu verziju upitnika za školski razred njihove djece.

3. Uz upitnike, koordinatori će razrednicima podijeliti evidencijske liste i podsjetnike roditeljima za vraćanje upitnika.

4. Ukoliko na evidencijskim listama nije navedeno ime nekog djeteta koje ide $u$ vaš razred $i$ sudjeluje u JOBSTEM projektu, molimo dodajte ga na popis i uručite mu također upitnik za roditelja.

\section{B. PODJELA UPITNIKA RODITELJIMA PREKO UČENIKA:}

1. Razrednik svakom učeniku u svom razrednom odjelu treba uručiti po jedan upitnik u omotnici, uz objašnjenje i napomenu:

- da je riječ o upitnicima za njihove roditelje unutar JOBSTEM projekta u kojem sudjeluju;

- da upitnik popunjava samo jedan od roditelja/skrbnika;

- da učenik treba popunjen upitnik od roditelja vratiti u zatvorenoj omotnici u roku od tri dana;

- da se na početku upitnika nalaze upute za roditelje

- da treba voditi posebno računa o pravovremenom povratku upitnika.

\section{VOĐENJE EVIDENCIJE I PODSJEĆANJE:}

1. Razrednik treba na evidencijskoj listi koju je zaprimio od koordinatora označiti one učenike koji su preuzeli upitnike.

2. Po povratku upitnika razrednik treba na evidencijskoj listi označiti one učenike koji su vratili upitnike. 
3. Nakon isteka roka od tri dana za vraćanje upitnika, razrednik treba onim učenicima koji još nisu vratili upitnike podijeliti podsjetnike za roditelje koje će također dobiti od koordinatora.

4. Molimo Vas uložite poseban trud u podsjećanje učenika i osigurajte što veći povrat ispunjenih upitnika.

5. Cjelokupni proces prikupljanja upitnika ne bi trebao premašiti vremenski period od ukupno 7 dana.

\section{POVRATAK UPITNIKA I PREDAJA ŠKOLSKOM KOORDINATORU:}

1. Nakon što roditelj ispuni upitnik, vraća ga po učeniku u zatvorenoj omotnici koju učenik predaje razredniku.

2. Važno je da razrednik, koordinator ili bilo tko drugi od školskih djelatnika ne otvara omotnice s upitnicima, kako bi se osigurala anonimnost i povjerljivost koja je zajamčena roditeljima.

3. Razrednik nakon prikupljanja upitnika, treba provjeriti da li broj prikupljenih upitnika odgovara broju označenih učenika u evidencijskim listama.

4. Po obavljanju svih poslova, razrednik predaje školskom koordinatoru zatvorene omotnice s popunjenim upitnicima, evidencijske liste te neiskorištene upitnike.

5. Školski koordinatori trebaju voditi računa o pohrani upitnika i trebaju obratiti pozornost da ne miješaju upitnike iz pojedinih razrednih odjela. Uz upitnike svakog razrednog odjela treba priložiti i evidencijsku listu.

6. Školski koordinator treba posvetiti pozornost da vodi brigu o dinamici prikupljanja upitnika u razrednim odjelima.

7. Na kraju, nakon završetka ispitivanja, istraživači JOBSTEM projekta će preuzeti sve materijale u prostoru škole u dogovoru sa školskim koordinatorom.

Oko svih pitanja ili eventualnih poteškoća možete se javiti mailom na: mara.simunovic@pilar.hr ili na broj telefona: 0915587804 ili 01/ 4886155.

Hvala Vam na suradnji i pomoći pri provođenju testiranja unutar JOBSTEM projekta!

JOBSTEM istraživački tim 
Prilog 2. Rezultati nezavisnih t-testova na učeničkim varijablama za učenike čiji su roditelji sudjelovali u roditeljskom istraživanju i učenike čiji roditelji nisu sudjelovali u istraživanju

\begin{tabular}{|c|c|c|c|c|c|c|c|c|c|}
\hline \multirow{2}{*}{$\begin{array}{c}\text { Varijabla } \\
\text { Matematika }\end{array}$} & \multicolumn{3}{|c|}{$\begin{array}{c}\text { Roditelj je } \\
\text { sudjelovao u } \\
\text { istraživanju }\end{array}$} & \multicolumn{3}{|c|}{$\begin{array}{l}\text { Roditelj nije } \\
\text { sudjelovao u } \\
\text { istraživanju }\end{array}$} & \multirow[b]{2}{*}{ t-test } & \multirow[b]{2}{*}{$p$} & \multirow[b]{2}{*}{$\begin{array}{c}\text { Cohen. } \\
\text { d }\end{array}$} \\
\hline & $M$ & $S D$ & $n$ & $M$ & $S D$ & $n$ & & & \\
\hline Samoefikasnost & 4.67 & 1.38 & 1064 & 4.29 & 1.42 & 127 & 2.94 & .003 & 0.27 \\
\hline Interes & 4.17 & 1.47 & 1063 & 4.19 & 1.52 & 127 & -0.11 & .916 & - \\
\hline Važnost & 5.41 & 1.10 & 1063 & 5.29 & 1.21 & 127 & 1.12 & .261 & - \\
\hline Sl. aktivnosti & 2.54 & 0.98 & 1056 & 2.58 & 1.04 & 126 & -0.46 & .647 & - \\
\hline Postignuće & 3.66 & 1.06 & 1063 & 3.29 & 1.12 & 125 & 3.63 & $\begin{array}{c}< \\
.001\end{array}$ & 0.34 \\
\hline $\begin{array}{c}\text { Tehnička } \\
\text { kultura }\end{array}$ & $M$ & $S D$ & $n$ & $M$ & $S D$ & $n$ & t-test & $p$ & $\begin{array}{c}\text { Cohen. } \\
\mathrm{d}\end{array}$ \\
\hline Samoefikasnost & 5.50 & 1.22 & 1063 & 5.53 & 1.14 & 127 & -0.27 & .786 & - \\
\hline Interes & 4.28 & 1.77 & 1064 & 4.24 & 1.61 & 127 & 0.27 & .790 & - \\
\hline Važnost & 4.30 & 1.43 & 1059 & 4.23 & 1.38 & 126 & 0.53 & .598 & - \\
\hline Sl. aktivnosti & 2.50 & 0.96 & 1055 & 2.55 & 1.08 & 126 & -0.62 & .537 & - \\
\hline Postignuće & 4.62 & 0.58 & 1063 & 4.50 & 0.62 & 125 & 2.34 & .019 & - \\
\hline
\end{tabular}

Napomena. Alpha razina značajnosti postavljena je na .005. Razlike koje su značajne uz korigiranu Alpha vrijednost prikazane su podebljano. 
Prilog 3. Rezultati Mardia testa za ispitivanje multivarijatne normalnosti podataka za svih šest SEM modela

\begin{tabular}{ccc}
\hline Model & $\begin{array}{c}\text { Mardia } \\
\text { asimetričnost }\end{array}$ & $\begin{array}{c}\text { Mardia } \\
\text { spljoštenost }\end{array}$ \\
\hline Matematika & & \\
\hline Samoefikasnost & 4535.74 & 9.09 \\
Interes & 4642.81 & 10.24 \\
Važnost & 4732.54 & 7.93 \\
\hline Tehnička kultura & & \\
\hline Samoefikasnost & 7363.82 & 8.88 \\
Interes & 6342.95 & 8.74 \\
Važnost & 6386.81 & 8.84 \\
\hline
\end{tabular}

Napomena. Sve vrijednosti su značajne na $p<.001$. 
Prilog 4. Standardizirana faktorska zasićenja u konačnim mjernim modelima iz matematike i tehničke kulture

\begin{tabular}{|c|c|c|c|}
\hline Latentni konstrukt & $\begin{array}{c}\text { Redni } \\
\text { broj } \\
\text { opažene } \\
\text { varijable }\end{array}$ & $\begin{array}{c}\text { Faktorsko } \\
\text { zasićenje - } \\
\text { Matematika }\end{array}$ & $\begin{array}{c}\text { Faktorsko } \\
\text { zasićenje - } \\
\text { Tehnička } \\
\text { kultura } \\
\end{array}$ \\
\hline \multirow{4}{*}{ Roditeljska uvjerenja specifična za dijete } & 1. & .95 & .70 \\
\hline & 2. & .41 & .49 \\
\hline & 3. & .74 & .88 \\
\hline & 4. & - & .56 \\
\hline \multirow{3}{*}{ Roditeljsko modeliranje aktivnosti } & 1. & .85 & .81 \\
\hline & 2. & .74 & .48 \\
\hline & 3. & - & .60 \\
\hline \multirow{2}{*}{ Roditeljska uključenost } & 1. & .86 & .93 \\
\hline & 2. & .94 & .91 \\
\hline \multirow{4}{*}{ Roditeljsko poticanje interesa } & 1. & .63 & .47 \\
\hline & 2. & .83 & .78 \\
\hline & 3. & .59 & .74 \\
\hline & 4. & - & .46 \\
\hline \multirow{5}{*}{ Učenička samoefikasnosti } & 1. & .95 & .92 \\
\hline & 2. & .86 & .90 \\
\hline & 3. & .81 & .84 \\
\hline & 4. & .89 & .81 \\
\hline & 5. & - & .77 \\
\hline \multirow{4}{*}{ Učenički interes za predmet } & 1. & .88 & .88 \\
\hline & 2. & .63 & .80 \\
\hline & 3. & .92 & .92 \\
\hline & 4. & .89 & .86 \\
\hline \multirow{4}{*}{ Učenička važnost predmeta } & 1. & .59 & .90 \\
\hline & 2. & .59 & .92 \\
\hline & 3. & .79 & .73 \\
\hline & 4. & .81 & .61 \\
\hline \multirow{4}{*}{ Učeničke slobodne aktivnosti } & 1. & .77 & .48 \\
\hline & 2. & .84 & .80 \\
\hline & 3. & .53 & .72 \\
\hline & 4. & - & .47 \\
\hline
\end{tabular}

Napomena. Faktorska zasićenja za roditeljske varijable te indikatore učeničkih slobodnih aktivnosti su izračunate na temelju modela s varijablom učeničke samoefikasnosti iz matematike te modela $\mathrm{s}$ učeničkom samoefikasnosti iz tehničke kulture. Faktorska zasićenja za ove varijable u ostalim modelima (s učeničkim interesom i važnosti iz matematike i tehničke kulture) se minimalno razlikuju od ovdje prikazanih zasićenja (za vrijednost druge decimale).

Sva faktorska zasićenja su značajna na $p<.001$. 
Prilog 5. Korelacije između latentnih varijabli u mjernim modelima iz matematike i tehničke kulture (vrijednosti za modele iz matematike su ispod, a vrijednosti za modele iz tehničke kulture su iznad dijagonale)

\begin{tabular}{|c|c|c|c|c|c|c|}
\hline Varijable & $\begin{array}{l}\text { 1. Roditeljska } \\
\text { uvjerenja }\end{array}$ & $\begin{array}{l}\text { 2. Roditeljsko } \\
\text { modeliranje }\end{array}$ & $\begin{array}{l}\text { 3. Roditeljska } \\
\text { uključenost }\end{array}$ & $\begin{array}{l}\text { 4. Roditeljsko } \\
\text { poticanje }\end{array}$ & $\begin{array}{l}\text { 5. Učeničko } \\
\text { motivacijsko } \\
\text { uvjerenje }^{\text {a }}\end{array}$ & $\begin{array}{l}\text { 6. Učeničke } \\
\text { slobodne } \\
\text { aktivnosti }\end{array}$ \\
\hline 1. Roditeljska uvjerenja & 1 & $.18^{* * *}$ & -.07 & $.35^{* * *}$ & $\begin{array}{c}.47^{* * *} / .41^{* * *} / \\
.31^{* * *}\end{array}$ & $.30^{* * * *}$ \\
\hline $\begin{array}{l}\text { 2. Roditeljsko } \\
\text { modeliranje }\end{array}$ & $.18^{* * * *}$ & 1 & $.30^{* * *}$ & $.62^{* * * *}$ & $\begin{array}{c}.10 \% / .16^{* * * *} / \\
.18^{* * * *}\end{array}$ & $.14^{* *}$ \\
\hline 3. Roditeljska uključenost & $-.44^{* * * *}$ & $.23^{* * *}$ & 1 & $.22^{* * *}$ & $\begin{array}{l}-.12^{* * *} / .07^{*} / \\
.13^{* * *}\end{array}$ & .02 \\
\hline 4. Roditeljsko poticanje & $.18^{* * *}$ & $.66^{* * *}$ & $.27^{* * *}$ & 1 & $\begin{array}{c}.17^{* * *} / .21^{* * *} / \\
.24^{* * *}\end{array}$ & $.43^{* * *}$ \\
\hline $\begin{array}{l}\text { 5. Učeničko motivacijsko } \\
\text { uvjerenje a }\end{array}$ & $\begin{array}{c}.83^{* * *} / .54^{* * *} / \\
.46^{* * *}\end{array}$ & $\begin{array}{c}.14^{* * * *} / .10^{* * *} / \\
.09^{*}\end{array}$ & $\begin{array}{c}-.39^{* * *} /-.25^{* * *} / \\
-.17^{* * *}\end{array}$ & $\begin{array}{c}.17^{* * *} / .22^{* * *} / \\
.14^{* *}\end{array}$ & 1 & $\begin{array}{c}.26^{* * * *} / .40^{* * * *} / \\
.36^{* * *}\end{array}$ \\
\hline $\begin{array}{l}\text { 6. Učeničke slobodne } \\
\text { aktivnosti }\end{array}$ & $.32^{* * * *}$ & $.13^{* *}$ & $-.15^{* * *}$ & $.22^{* * *}$ & $\begin{array}{c}.45^{* * *} / .59^{* * * *} / \\
.47^{* * * *}\end{array}$ & 1 \\
\hline
\end{tabular}

Napomena. ${ }^{a}$ Prva vrijednost u ćelijama se odnosi na korelaciju s učeničkom samoefikasnosti u predmetu; druga vrijednost na korelaciju s učeničkim interesom za predmet; treća vrijednost na korelaciju s učeničkom važnosti predmeta.

$* * * p<.001 ; * * p<.01 ; * p<.05$. 
Prilog 6. Prikaz standardiziranih izravnih učinaka u tri konačna strukturalna modela iz matematike

Model (vrsta motivacijskog uvjerenja učenika)

\begin{tabular}{|c|c|c|c|c|}
\hline Prediktor & Zavisna varijabla & $\begin{array}{c}\text { Samoefi- } \\
\text { kasnost }\end{array}$ & Interes & Važnost \\
\hline \multirow{4}{*}{ Rod učenika } & Roditeljska uvjerenja & $-.07^{* * *}$ & $-.07^{* *}$ & $-.06^{* *}$ \\
\hline & Roditeljsko pribavljanje STEM materijala & $-.12^{* * *}$ & $-.11^{* * *}$ & $-.11^{* * *}$ \\
\hline & Učeničko motivacijsko uvjerenje & l & l & .00 \\
\hline & Učeničko postignuće & $.08^{* * *}$ & $.07^{* * *}$ & $.07^{* * *}$ \\
\hline \multirow{2}{*}{ Razred učenika } & Učeničko motivacijsko uvjerenje & l & $-.06^{*}$ & $-.15^{* * *}$ \\
\hline & Učeničke slobodne aktivnosti & $-.15^{* * *}$ & $-.09^{* *}$ & $-.07^{*}$ \\
\hline \multirow{7}{*}{ Prošlo postignuće učenika } & Roditeljska uvjerenja & $.83^{* * *}$ & $.82^{* * *}$ & $.84^{* * *}$ \\
\hline & Roditeljska uključenost & .00 & .00 & .00 \\
\hline & Roditeljsko poticanje & .00 & .00 & $-.19^{* *}$ \\
\hline & Roditeljsko pribavljanje STEM materijala & .00 & .00 & $-.13^{*}$ \\
\hline & Učeničko motivacijsko uvjerenje & $.21^{* * *}$ & .00 & .00 \\
\hline & Učeničke slobodne aktivnosti & $-.27^{* * *}$ & .00 & .00 \\
\hline & Učeničko postignuće & $.44^{* * *}$ & $.53^{* * *}$ & $.49^{* * *}$ \\
\hline \multirow{6}{*}{ Roditeljsko obrazovanje } & Roditeljska uvjerenja & .00 & .00 & .00 \\
\hline & Roditeljsko poticanje & .00 & .00 & .00 \\
\hline & Roditeljsko pribavljanje STEM materijala & $.11^{* * *}$ & $.11^{* * *}$ & $.12^{* * *}$ \\
\hline & Učeničko motivacijsko uvjerenje & .00 & .00 & .00 \\
\hline & Učeničke slobodne aktivnosti & .00 & .00 & .00 \\
\hline & Učeničko postignuće & $.07^{* * *}$ & $.07^{* * *}$ & $.07^{* * *}$ \\
\hline \multirow{5}{*}{ Roditeljska uvjerenja } & Roditeljska uključenost & $-.44^{* * *}$ & $-.45^{* * *}$ & $-.44^{* * *}$ \\
\hline & Roditeljsko poticanje & $.17^{* * *}$ & $.16^{* * *}$ & $.35^{* * *}$ \\
\hline & Roditeljsko pribavljanje STEM materijala & $.17^{* * *}$ & $.16^{* * *}$ & $.28^{* * *}$ \\
\hline & Učeničko motivacijsko uvjerenje & $.67^{* * *}$ & $.45^{* * *}$ & $.44^{* * *}$ \\
\hline & Učeničko postignuće & $.20^{* * *}$ & $.34^{* * *}$ & $.39^{* * *}$ \\
\hline \multirow{2}{*}{ Roditeljska uključenost } & Učeničko motivacijsko uvjerenje & .00 & $-.10^{* *}$ & .00 \\
\hline & Učeničke slobodne aktivnosti & $-.08^{*}$ & .00 & $-.14^{* * *}$ \\
\hline \multirow{2}{*}{ Roditeljsko poticanje } & Učeničko motivacijsko uvjerenje & .00 & $.17^{* * *}$ & .00 \\
\hline & Učeničke slobodne aktivnosti & $.18^{* * *}$ & $.11^{* *}$ & $.23^{* * *}$ \\
\hline \multirow{2}{*}{$\begin{array}{l}\text { Roditeljsko pribavljanje } \\
\text { STEM materijala }\end{array}$} & Učeničko motivacijsko uvjerenje & .00 & .00 & .00 \\
\hline & Učeničke slobodne aktivnosti & .00 & .00 & .00 \\
\hline \multirow{2}{*}{$\begin{array}{c}\text { Učeničko motivacijsko } \\
\text { uvjerenje }\end{array}$} & Učeničke slobodne aktivnosti & $.59^{* * *}$ & $.55^{* * *}$ & $.42^{* * *}$ \\
\hline & Učeničko postignuće & $.29^{* * * *}$ & .00 & .00 \\
\hline $\begin{array}{l}\text { Učeničke slobodne } \\
\text { aktivnosti }\end{array}$ & Učeničko postignuće & $-.08^{* * *}$ & .00 & .00 \\
\hline
\end{tabular}

Napomena. / = put nije specificiran u modelu; $.00=\mathrm{u}$ konačnom je modelu put fiksiran na nulu zbog statističke neznačajnosti u početnom modelu. $* * * p<.001 ; * * p<.01 ; * p<.05$. 
Prilog 7. Prikaz standardiziranih izravnih učinaka u tri konačna strukturalna modela iz tehničke kulture

Model (vrsta motivacijskog uvjerenja učenika)

\begin{tabular}{|c|c|c|c|c|}
\hline Prediktor & Zavisna varijabla & $\begin{array}{l}\text { Samoefi- } \\
\text { kasnost }\end{array}$ & Interes & Važnost \\
\hline \multirow{7}{*}{ Rod učenika } & Roditeljska uvjerenja & $-.11^{* *}$ & $-.12^{* * *}$ & $-.12^{* * *}$ \\
\hline & Roditeljska uključenost & .00 & .00 & .00 \\
\hline & Roditeljsko poticanje & $-.19^{* * *}$ & $-.19^{* * *}$ & $-.19^{* * *}$ \\
\hline & Roditeljsko pribavljanje STEM materijala & $-.13^{* * *}$ & $-.14^{* * *}$ & $-.13^{* * *}$ \\
\hline & Učeničko motivacijsko uvjerenje & .00 & $-.17^{* * *}$ & $-.22^{* * *}$ \\
\hline & Učeničke slobodne aktivnosti & $-.09^{*}$ & .00 & .00 \\
\hline & Učeničko postignuće & $.06^{*}$ & $.06^{*}$ & $.06^{*}$ \\
\hline \multirow{4}{*}{ Razred učenika } & Roditeljska uvjerenja & .00 & .00 & .00 \\
\hline & Roditeljsko poticanje & .00 & .00 & .00 \\
\hline & Učeničko motivacijsko uvjerenje & / & .00 & .00 \\
\hline & Učeničke slobodne aktivnosti & $-.10^{* *}$ & .00 & .00 \\
\hline \multirow{7}{*}{ Prošlo postignuće učenika } & Roditeljska uvjerenja & $.42^{* * * *}$ & $.37^{* * *}$ & $.38^{* * * *}$ \\
\hline & Roditeljska uključenost & $-.21^{* * *}$ & $-.22^{* * *}$ & $-.22^{* * *}$ \\
\hline & Roditeljsko poticanje & .00 & .00 & .00 \\
\hline & Roditeljsko pribavljanje STEM materijala & .00 & .00 & .00 \\
\hline & Učeničko motivacijsko uvjerenje & $.16^{* * *}$ & I & l \\
\hline & Učeničke slobodne aktivnosti & .00 & .00 & .00 \\
\hline & Učeničko postignuće & $.62^{* * *}$ & $.63^{* * *}$ & $.63^{* * *}$ \\
\hline \multirow{6}{*}{ Roditeljsko obrazovanje } & Roditeljska uvjerenja & $-.15^{* * *}$ & $-.14^{* * *}$ & $-.14^{* * *}$ \\
\hline & Roditeljsko poticanje & $.09^{*}$ & $.09^{*}$ & $.11^{* *}$ \\
\hline & Roditeljsko pribavljanje STEM materijala & $.16^{* * *}$ & $.16^{* * *}$ & $.16^{* * *}$ \\
\hline & Učeničko motivacijsko uvjerenje & I & $-.18^{* * *}$ & $-.15^{* * *}$ \\
\hline & Učeničke slobodne aktivnosti & .00 & $.09^{*}$ & .00 \\
\hline & Učeničko postignuće & $.13^{* * *}$ & $.13^{* * *}$ & $.14^{* * *}$ \\
\hline \multirow{5}{*}{ Roditeljska uvjerenja } & Roditeljska uključenost & .00 & .00 & .00 \\
\hline & Roditeljsko poticanje & $.28^{* * *}$ & $.27^{* * *}$ & $.29^{* * *}$ \\
\hline & Roditeljsko pribavljanje STEM materijala & $.19^{* * * *}$ & $.17^{* * *}$ & $.19^{* * * *}$ \\
\hline & Učeničko motivacijsko uvjerenje & $.46^{* * *}$ & $.38^{* * *}$ & $.29^{* * *}$ \\
\hline & Učeničko postignuće & .00 & $.08^{* *}$ & $.09^{* *}$ \\
\hline \multirow{2}{*}{ Roditeljsko modeliranje } & Učeničko motivacijsko uvjerenje & .00 & $.11^{* *}$ & $.12^{* *}$ \\
\hline & Učeničke slobodne aktivnosti & $-.21^{* * *}$ & $-.24^{* * *}$ & $-.28^{* * *}$ \\
\hline \multirow{2}{*}{ Roditeljska uključenost } & Učeničko motivacijsko uvjerenje & .00 & .00 & $.08^{*}$ \\
\hline & Učeničke slobodne aktivnosti & .00 & .00 & .00 \\
\hline \multirow{2}{*}{ Roditeljsko poticanje } & Učeničko motivacijsko uvjerenje & .00 & .00 & .00 \\
\hline & Učeničke slobodne aktivnosti & $.50^{* * *}$ & $.50^{* * *}$ & $.56^{* * *}$ \\
\hline \multirow{2}{*}{$\begin{array}{l}\text { Roditeljsko pribavljanje } \\
\text { STEM materijala }\end{array}$} & Učeničko motivacijsko uvjerenje & $-.07^{*}$ & .00 & .00 \\
\hline & Učeničke slobodne aktivnosti & .00 & .00 & .00 \\
\hline \multirow{2}{*}{$\begin{array}{c}\text { Učeničko motivacijsko } \\
\text { uvjerenje }\end{array}$} & Učeničke slobodne aktivnosti & $.21^{* * *}$ & $.36^{* * *}$ & $.29^{* * * *}$ \\
\hline & Učeničko postignuće & $.11^{* * *}$ & .00 & .00 \\
\hline $\begin{array}{c}\text { Učeničke slobodne } \\
\text { aktivnosti }\end{array}$ & Učeničko postignuće & .00 & .00 & .00 \\
\hline
\end{tabular}

Napomena. / = put nije specificiran u modelu; $.00=\mathrm{u}$ konačnom je modelu put fiksiran na nulu zbog statističke neznačajnosti u početnom modelu.

$* * * p<.001 ; * * p<.01 ; * p<.05$. 
Prilog 8. Proporcija objašnjene varijance za endogene varijable u strukturalnim modelima

\begin{tabular}{|c|c|c|c|c|c|c|}
\hline \multirow[b]{2}{*}{ Endogena varijabla } & \multicolumn{3}{|c|}{ Modeli - Matematika } & \multicolumn{3}{|c|}{ Modeli - Tehnička kultura } \\
\hline & Samoef. & Interes & Važnost & Samoef. & Interes & Važnost \\
\hline Roditeljska uvjerenja & .68 & .67 & .69 & .15 & .12 & .13 \\
\hline Roditeljska uključenost & .20 & .20 & .19 & .04 & .05 & .05 \\
\hline Roditeljsko poticanje & .03 & .03 & .05 & .12 & .12 & .13 \\
\hline $\begin{array}{l}\text { Roditeljsko pribavljanje } \\
\text { STEM materijala }\end{array}$ & .07 & .06 & .07 & .08 & .08 & .08 \\
\hline $\begin{array}{l}\text { Učeničko motivacijsko } \\
\text { uvjerenje }\end{array}$ & .72 & .31 & .23 & .28 & .23 & .18 \\
\hline Učeničke slobodne aktivnosti & .27 & .36 & .28 & .27 & .34 & .32 \\
\hline Učeničko postignuće & .78 & .75 & .76 & .52 & .52 & .51 \\
\hline
\end{tabular}




\section{9. ŽIVOTOPIS}

Mara Šimunović rođena je u Zagrebu 1990. godine gdje je završila osnovnu školu i opću gimnaziju. Na Odsjeku za psihologiju Filozofskog fakulteta Sveučilišta u Zagrebu diplomirala je 2014. godine. Za svoj diplomski rad primila je zahvalnicu Udruge "SVE za NJU!" za promicanje važnosti psihološke skrbi o ženama liječenim od raka dojke. Vježbenički staž obavila je na Odjelu za obrazovanje Pučkog otvorenog učilišta u Zagrebu te je 2015. godine položila stručni ispit pri Hrvatskoj psihološkoj komori čime je stekla osnovnu dopusnicu za samostalno obavljanje psihološke djelatnosti. Od 2016. godine zaposlena je kao asistentica na Institutu društvenih znanosti Ivo Pilar u Zagrebu. Poslijediplomski doktorski studij psihologije na Filozofskom fakultetu Sveučilišta u Zagrebu upisala je 2017. godine. Dobitnica je Stipendije Grada Zagreba za izvrsnost doktorandima studija u Gradu Zagrebu.

Izabrana je u suradničko zvanje asistenta na Katedri za zdravstvenu psihologiju Zdravstvenog veleučilišta u Zagrebu gdje od 2019. godine sudjeluje u izvođenju nastave na većem broju kolegiju kao što su Metode prikupljanja i analize podataka, Osnove istraživačkog rada u sestrinstvu, Zdravstvena psihologija i Komunikacijske vještine. Do sada je kao istraživač sudjelovala u radu pet domaćih i međunarodnih znanstveno-istraživačkih projekata, od čega su tri longitudinalna istraživačka projekta Hrvatske zaklade za znanost. Bila je suradnica i na većem broju razvojno-tehničkih projekata financiranih iz EU fondova i programa. Završila je program usavršavanja "Voditelj izrade i provedbe projekata financiranih iz EU fondova i programa" na Pučkom otvorenom učilištu u Zagrebu 2015. godine.

Do sada je u koautorstvu objavila sedam znanstvenih i jedan stručni rad te s priopćenjima sudjelovala na desetak domaćih i međunarodnih znanstvenih skupova. Od 2017. godine je sudjelovala na devet edukacija i ljetnih škola iz metodologije društvenih znanosti i naprednih statističkih analiza, poput višerazinskog modeliranja i analiza longitudinalnih podataka. Dobitnica je stipendije Njemačke akademske službe za razmjenu (Deutsche Akademische Auslandsdienst DAAD) za sudjelovanje na Ljetnoj školi Instituta GESIS u Kölnu 2019. godine.

\section{Bibliografija:}

\section{Znanstveni radovi}

Šimunović, M. i Babarović, T. (2020). The role of parental socializing behaviors in two domains of student STEM career interest. Research in Science Education. Rana online objava. doi: 10.1007/s11165-020-09938-6 
Šimunović, M., Babarović, T. i Šverko, I. (2020). Zanimanja roditelja i STEM profesionalni interesi srednjoškolaca. Društvena istraživanja, 29(2), 309-328. doi: 10.5559/di.29.2.07

Šimunović, M. i Babarović, T. (2020). The role of parents' beliefs in students' motivation, achievement, and choices in the STEM domain: a review and directions for future research. Social Psychology of Education, 23, 701-719. doi: 10.1007/s11218-020-09555-1

Babarović, T., Šverko, I. i Šimunović, M. (2020). Career Choice - The new online career guidance system in Croatia. U Š. Grajcár, Štefan i T. Šprlák (Ur.), Career guidance for inclusive society: Conference proceedings (str. 32-49). Bratislava: Združenie pre kariérové poradenstvo a rozvoj kariéry.

Burušić, J., Šimunović, M., i Šakić Velić, M. (2019). Technology-based activities at home and STEM school achievement: the moderating effects of student gender and parental education. Research in Science \& Technological Education. Rana online objava. doi: $10.1080 / 02635143.2019 .1646717$

Šimunović, M. i Ljubotina D. (2019). Prevalence, structure and predictors of posttraumatic stress disorder symptoms in Croatian patients following breast cancer. Psychiatria Danubina, 32(2), 187-196. doi: 10.24869/psyd.2020.187

Šimunović M., Reić-Ercegovac, I. i Burušić, J. (2018). How important is it to my parents? Transmission of STEM academic values: The role of parents' values and practices and children's perceptions of parental influences. International Journal of Science Education, 40(9), 977-995. doi: 10.1080/09500693.2018.1460696

\section{Stručni radovi}

Šimunović, M. i Burušić, J. (2018). Suvremeni pristupi i metode rada s roditeljima i obiteljima u STEM obrazovnom kontekstu. Matematika i škola, 20(96), 15-19. 